Cíntia Cristina Vieira

\title{
CONFORTO TÉRMICO E ILUMINAÇÃO NATURAL NO EDIFÍCIO ADMINISTRATIVO DA ESCOLA DE ENGENHARIA DE SÃO CARLOS / USP - O BLOCO E1
}

Dissertação apresentada ao Departamento de Arquitetura e Urbanismo da Escola de Engenharia de São Carlos da Universidade de São Paulo para obtenção do título de Mestre em Arquitetura e Urbanismo.

Área de concentração: Arquitetura, Urbanismo e Tecnologia.

Orientadora: Prof ${ }^{\mathrm{a}}$. Associada Rosana Maria Caram

São Carlos 
AUTORIZO A REPRODUÇÄO E DIVULGAÇĀO TOTAL OU PARCIAL DESTE TRABALHO, POR QUALQUER MEIO CONVENCIONAL OU ELETRÔNICO, PARA FINS DE ESTUDO E PESQUISA, DESDE QUE CITADA A FONTE.

Ficha catalográfica preparada pela Seção de Tratamento da Informação do Serviço de Biblioteca - EESC/USP

Vieira, Cíntia Cristina
V658c Conforto térmico e iluminação natural no edifício administrativo da Escola de Engenharia de São Carlos/USP - obloco El / Cintia Cristina Vieira ; orientadora Rosana Maria Caran. -- São Carlos, 2008.

Dissertação (Mestrado - Programa de Pós-Graduação en Arquitetura e Urbanismo e Area de Concentraçāo em. Arquitetura, Urbanismo e Tecnologia) -- Escola de Engenharia de São Carlos da Universidade de São Paulo, 2008 .

1. Conforto térnico. 2. Iluminação natural. 3. Bloco $\mathrm{El}$ 
Dedico este trabalho à minha mãe Zuleika, minha grande amiga e ao meu marido Cezar, amor da minha vida 


\section{AGRADECIMENTOS}

Acima de tudo a Deus, por me dar força quando pensava que não iria conseguir.

Ao grande amor da minha vida, meu marido Cezar, que não mediu esforços para me ajudar e sempre esteve ao meu lado, sendo meu maior incentivador.

À minha mãe Zuleika, por tudo que me ensinou e me ensina e por ter possibilitado a minha formação.

Ao meu pai Sidney, que mesmo ausente, também possibilitou minha formação e me deixou importantes ensinamentos enquanto esteve entre nós.

À minha orientadora e grande amiga Rosana Maria Caram, pela sua orientação, incentivo e confiança depositada em mim.

Aos meus irmãos e aos meus sobrinhos, por sempre estarem ao meu lado.

À minha sobrinha-irmã Juliana que me auxiliou muito na parte prática desse trabalho, sempre com disposição e alegria, e pela sua amizade sincera.

Às amigas Rubia e Marcele pelas sugestões e palavras de carinho.

Aos professores Eduvaldo Paulo Sichieri e Lucila Chebel Labaki, pelas valiosas críticas e comentários feitos em meu exame de qualificação que muito me ajudaram.

Ao professor Maurício Roriz, pelas orientações muito pertinentes.

À Sra. Gitla Mange, esposa do engenheiro Ernest Robert de Carvalho Mange, por ter aberto seu arquivo pessoal para minha pesquisa. 
Ao Saulo Güths, funcionário do Laboratório de Meios Porosos e Propriedades Termofísicas da UFSC e responsável pelo desenvolvimento do Confortímetro, pelas suas orientações e prontidão em ajudar.

A todos os funcionários do Bloco E1, em especial à Glaucia, Josemara e Rosângela, funcionárias da Assistência Administrativa.

Aos funcionários da Seção de Documentação e Cadastro da Divisão de Obras da EESC/USP.

Agradeço a todos os funcionários e professores do Departamento de Arquitetura e Urbanismo da EESC/USP e a todos aqueles que de alguma forma contribuíram para este trabalho.

E a Fapesp - Fundação de Amparo à Pesquisa do Estado de São Paulo, pelo apoio financeiro concedido a essa pesquisa, essencial para o desenvolvimento deste trabalho. 


\section{RESUMO}

VIEIRA, C. C. (2008). Arquitetura, conforto térmico e iluminação natural no edifício administrativo da escola de engenharia de São Carlos / USP - o Bloco E1. Dissertação (Mestrado) - Escola de Engenharia de São Carlos, Universidade de São Paulo, São Carlos, 2008.

A presente pesquisa consiste em uma análise do edifício administrativo da Escola de Engenharia de São Carlos pertencente à Universidade de São Paulo, do ponto de vista de conforto térmico e iluminação natural. O processo de investigação se dá em algumas etapas: análise projetual enfatizando os aspectos relativos ao conforto ambiental (microclima, partidos arquitetônicos, implantação, materiais, técnicas construtivas, aberturas, envidraçamentos, diagramas e esquemas de estudo); aplicação de questionários aos usuários; e medições in loco de níveis de iluminação e de variáveis ambientais de conforto térmico. Os resultados foram analisados e comparados, para que a partir destes seja possível obter uma avaliação das soluções e técnicas empregadas quanto às questões de térmica e iluminação, contribuindo assim no aperfeiçoamento de técnicas projetuais. Objetiva-se com estas técnicas a obtenção de conforto ambiental e redução no consumo de energia, para edifícios do padrão do estudado, o qual é visto repetir-se incalculavelmente em edifícios administrativos, de escritórios e escolares.

Palavras-chave: Conforto térmico. lluminação natural. Bloco E1. 


\section{ABSTRACT}

VIEIRA, C. C. (2008). Architecture, thermal comfort and natural illumination in the administrative building of the School of Engineering of São Carlos / USP - the E1 Block. M. Sc. Dissertation - Escola de Engenharia de São Carlos, Universidade de São Paulo, São Carlos, 2008.

This research is an analysis of the administrative building of the Escola de Engenharia de São Carlos belonging to the Universidade de Sao Paulo, from the point of view of thermal comfort and natural illumination. The process of investigation takes place in some steps: architectural design analysis emphasizing aspects related to environmental comfort (microclimate, architectural parties, implantation, materials, constructive techniques, openings, glassing, diagrams, and study schemes); application of questionnaires to users, and on-site measurements of environmental variables of thermal comfort and levels of illumination. The results were analyzed and compared, so that from the results it's possible to evaluate the solutions and applied techniques related to thermal and illumination aspects, thus contributing in the development of design techniques. The objective with these techniques is obtaining environmental comfort and reduction in energy consumption in buildings with the same pattern of use, which is seen to be repeated a lot of times in buildings for administrative use, offices and schools.

Keywords: Thermal comfort. Natural Illumination. E1 Block. 


\section{LISTA DE FIGURAS}

Figura 1 - Esquema desenvolvido por Mange 34

Figura 2 - Relação entre $n^{\circ}$ de acidentes de trabalho e temp. do ambiente... 36

Figura 3 - PPD em função do PMV . 44

Figura 4 - Determinação de $\mathrm{H}_{\mathrm{m}}$ 50

Figura 5 - Exemplo de malha de pontos para medições. 51

Figura 6 - Jornal Gazeta de São Paulo (1952) sobre a criação da EESC................... 58

Figura 7 - Casa d'Itália - Primeiro edifício ocupado pela EESC...............................59

Figura 8 - Bloco E1 - Primeiro edifício a ser construído no campus da EESC ............59

Figura 9 - Mange em palestra apresentada na EESC sobre o Bloco E1 ....................60

Figura 10 - Plano para o campus da EESC - USP ............................................ 61

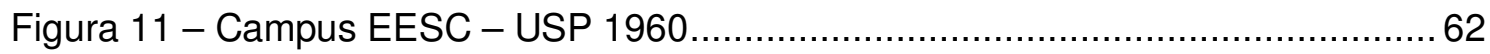

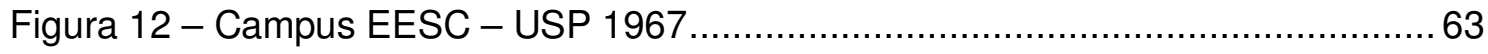

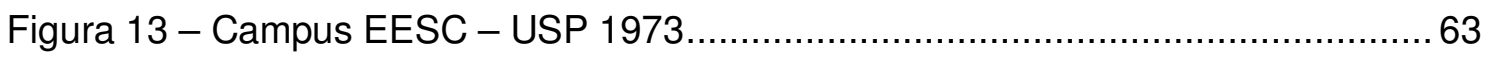

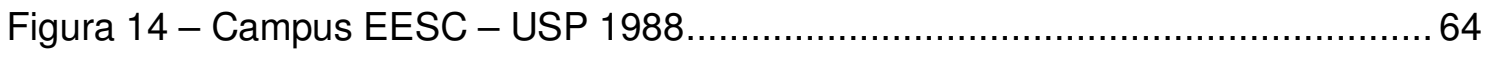

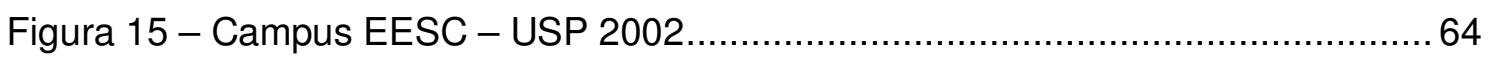

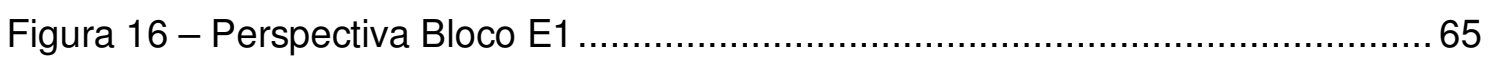

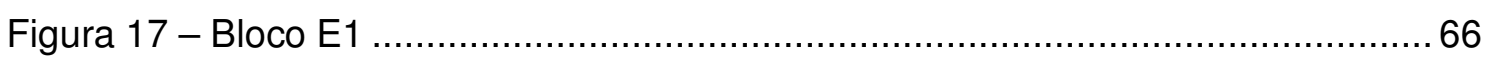

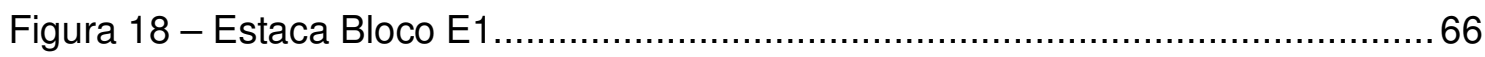

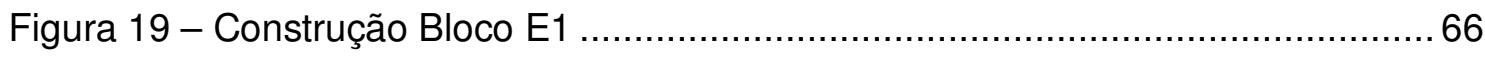

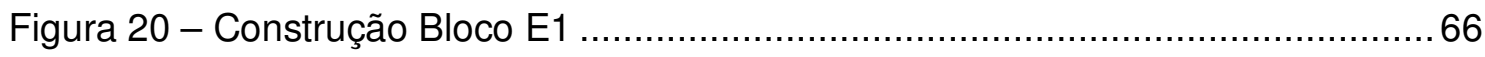

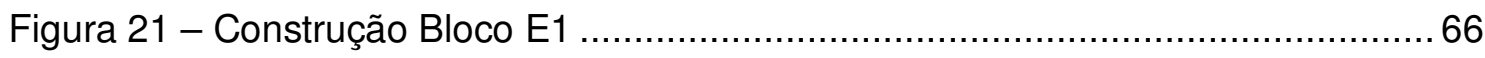

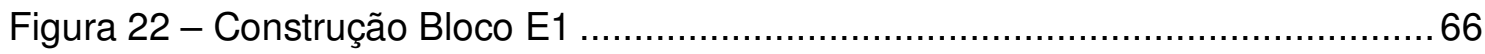

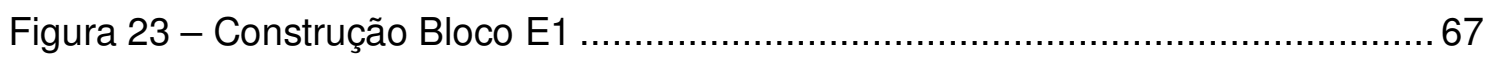

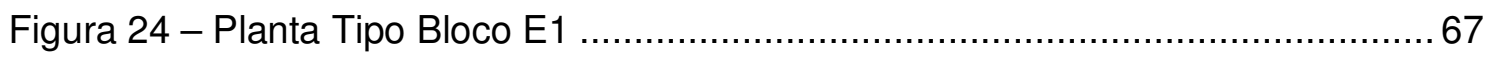

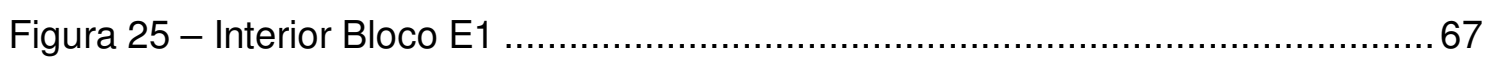

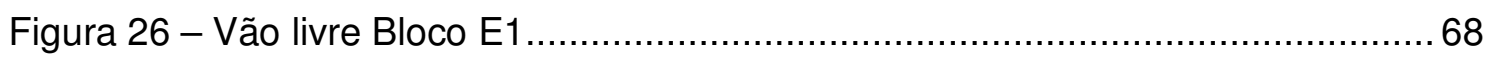

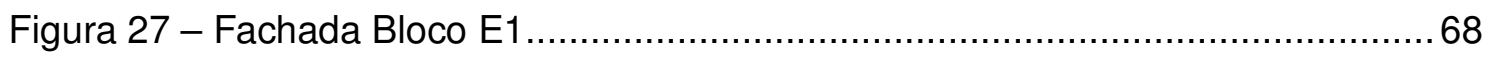

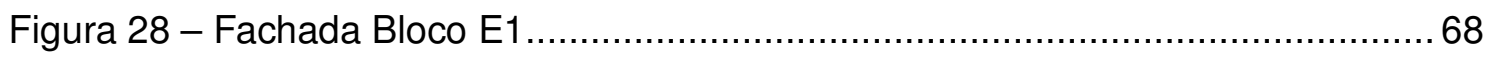

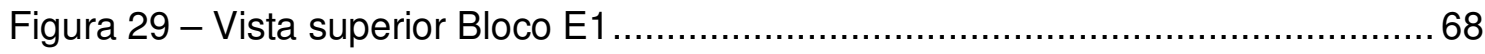

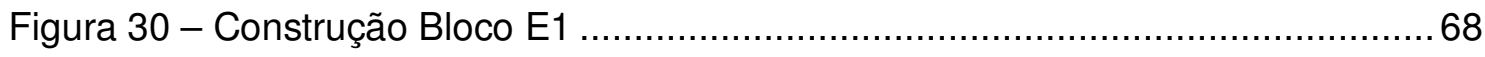

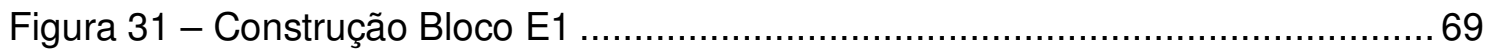

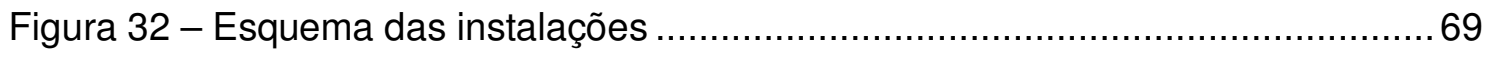

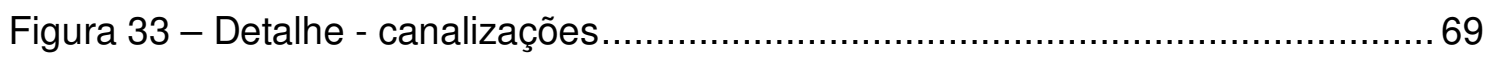

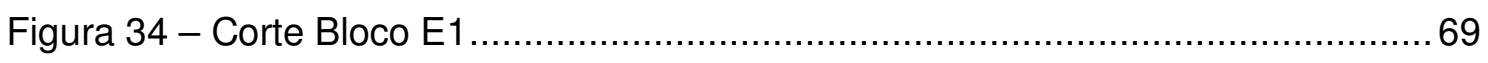

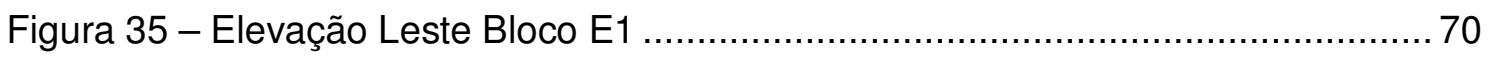




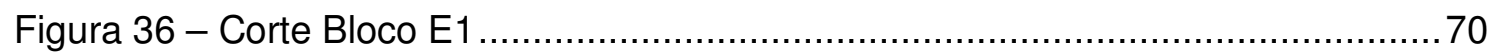

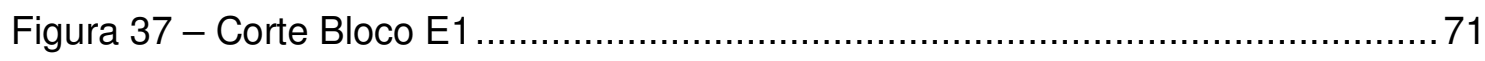

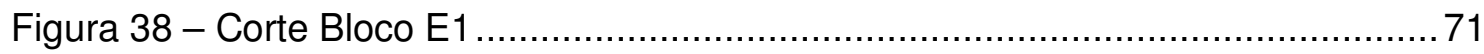

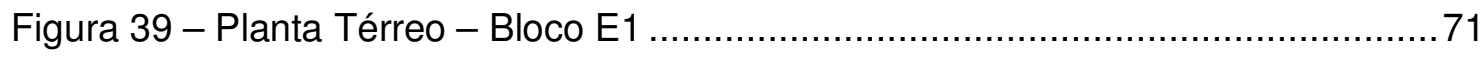

Figura 40 - Planta $1^{\circ}$ Pavimento - Bloco E1 ....................................................... 72

Figura 41 - Planta $2^{\circ}$ Pavimento - Bloco E1 ...................................................... 72

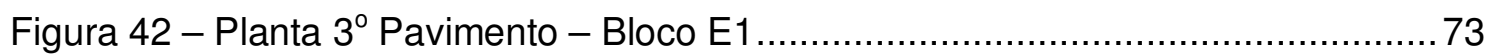

Figura 43 - Esquema de iluminação e ventilação naturais desenvolvido por Mange ...75

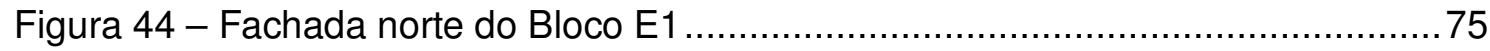

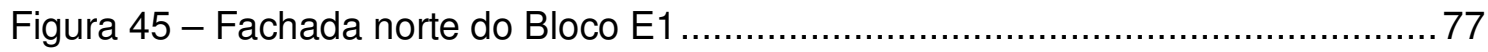

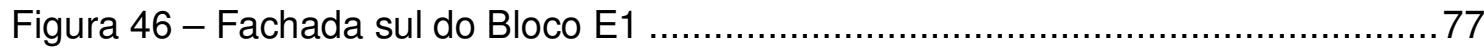

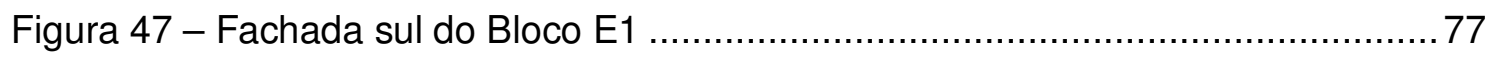

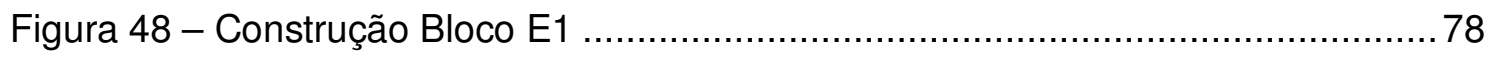

Figura 49 - Gráfico para iluminação desenvolvido por Mange .....................................79

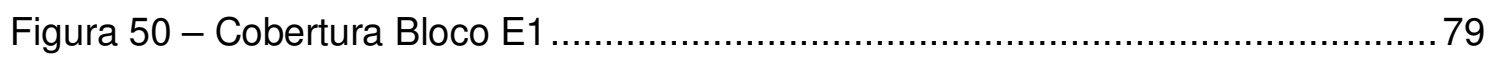

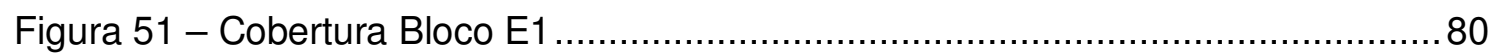

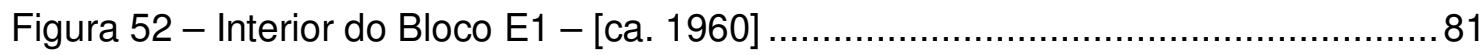

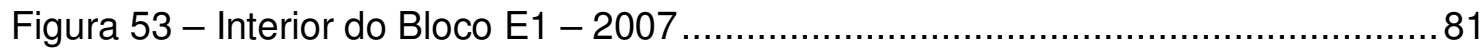

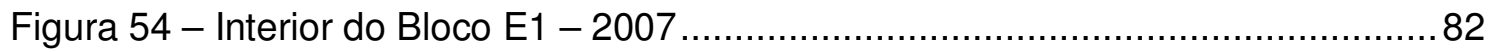

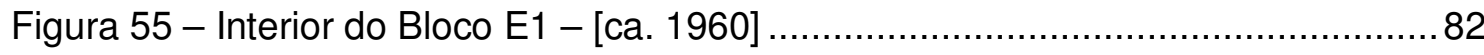

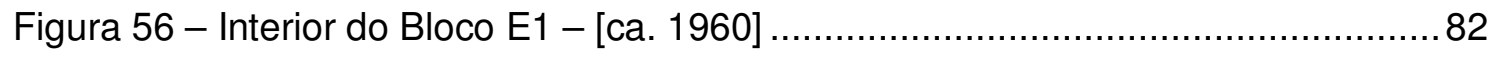

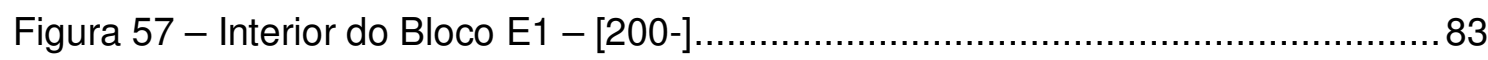

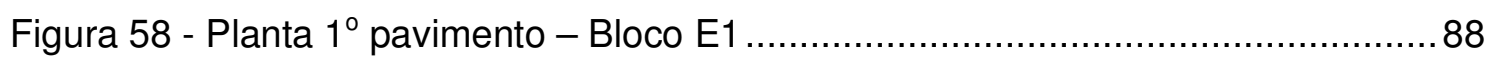

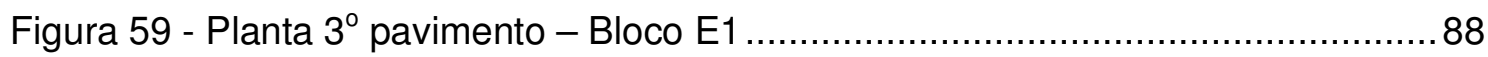

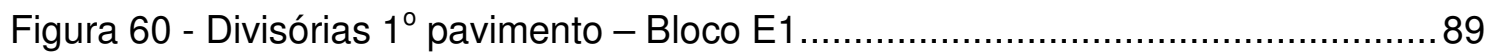

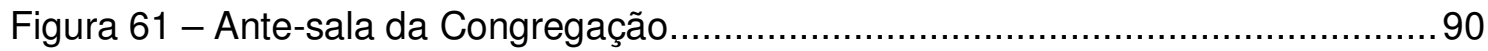

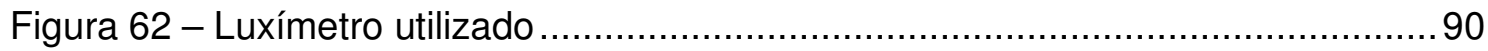

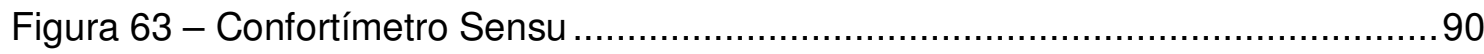

Figura 64 - Confortímetro Sensu ....................................................................... 91

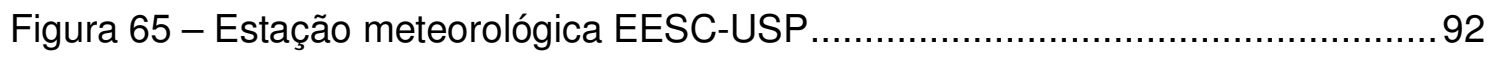

Figura 66 - Foto aérea campus São Carlos - USP ……………………………..... 93

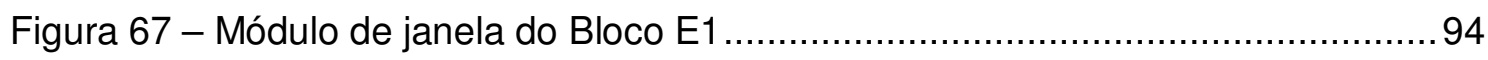

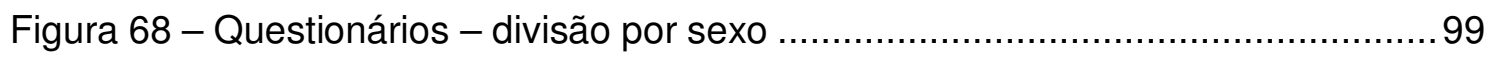

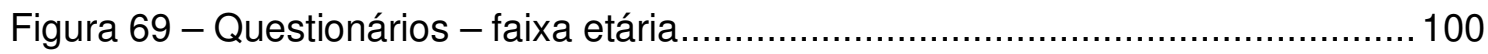

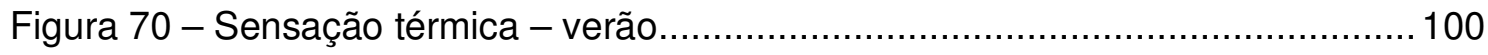

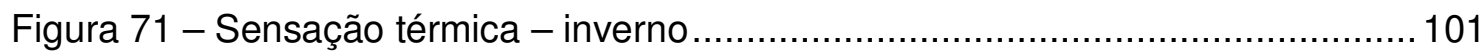

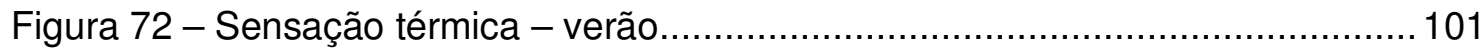




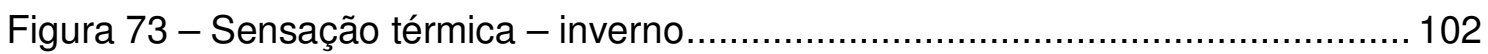

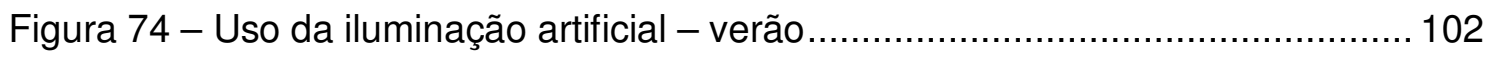

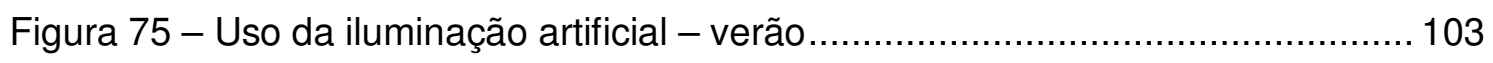

Figura 76 - Uso da iluminação artificial - inverno .................................................. 103

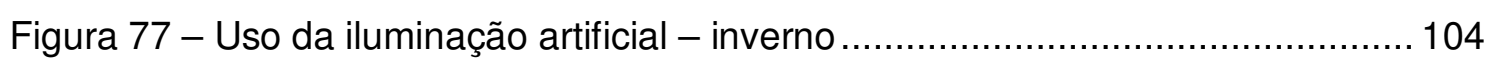

Figura 78 - lluminação natural na mesa de trabalho ............................................. 104

Figura 79 - Sensação quanto à transparência................................................... 105

Figura 80 - Planta - Assistência Administrativa - pontos de medição ....................... 107

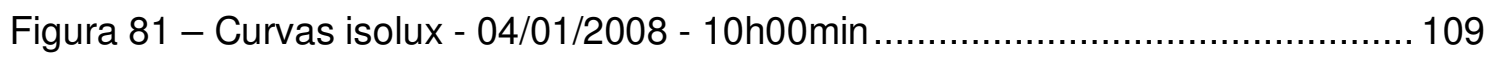

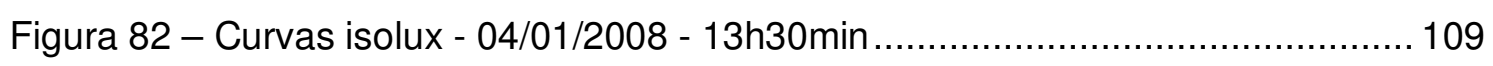

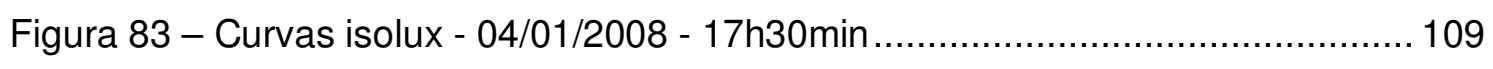

Figura 84 - Curvas isolux - 23/07/2007- 10h00min .............................................. 111

Figura 85 - Curvas isolux - 23/07/2007 - 13h30min .......................................... 111

Figura 86 - Curvas isolux - 23/07/2007 - 17h30min ............................................... 111

Figura 87 - Gráfico para iluminação desenvolvido por Mange ................................. 113

Figura 88 - Curvas de aclaramento - Verão - 13h30min ........................................ 114

Figura 89 - Curvas de aclaramento - Inverno - 13h30min .................................... 114

Figura 90 - Planta - Ante-sala da Congregação - pontos de medição....................... 115

Figura 91 - Curvas isolux - 04/01/2008 - 11h00min ............................................. 117

Figura 92 - Curvas isolux - 04/01/2008 - 14h30min ........................................... 117

Figura 93 - Curvas isolux - 04/01/2008 - 18h00min ......................................... 117

Figura 94 - Curvas isolux - 23/07/2007 - 11h00min ............................................. 119

Figura 95 - Curvas isolux - 23/07/2007 - 14h30min ............................................ 119

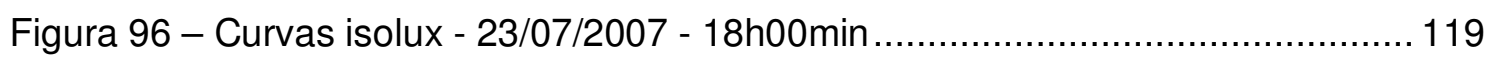

Figura 97 - Planta - Assistência Administrativa - localização do confortímetro ........ 122

Figura 98 - Temperatura do ar - 17/11/2006 ………….................................. 122

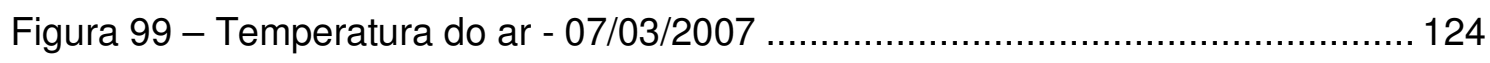

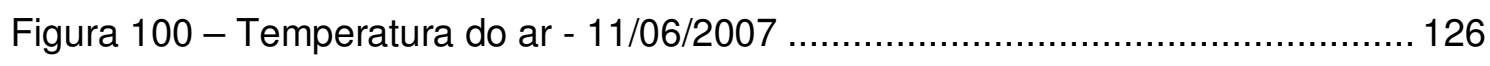

Figura 101 - Temperatura do ar - 28/06/2007 ………….............................. 128

Figura 102 - Planta - Ante-sala da Congregação - localização do confortímetro..... 130

Figura 103 - Temperatura do ar - 23/11/2006 ……………............................... 130

Figura 104 - Temperatura do ar - 24/11/2006 ................................................. 132

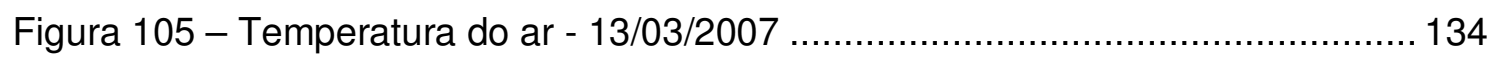

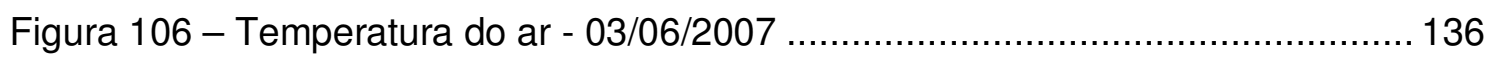

Figura 107 - Temperatura do ar - 07/07/2007 ................................................... 138 


\section{LISTA DE TABELAS}

Tabela 1 - Escala de sensação térmica de sete pontos ........................................ 43

Tabela 2 - Quantidade mínima de pontos a serem medidos ...................................50

Tabela 3 - Iluminâncias por classe de tarefas visuais.............................................. 52

Tabela 4 - Fatores determinantes da iluminância adequada ...................................53

Tabela 5 - Abertura de janelas durante as medições - Ante-sala da Congregação ... 95

Tabela 6 - lluminância por pontos - Assistência Administrativa - 04/01/2008........... 108

Tabela 7 - lluminância por pontos - Assistência Administrativa - 23/07/2007.......... 110

Tabela 8 - lluminância por pontos - Ante-sala da Congregação - 04/01/2008.......... 116

Tabela 9 - lluminância por pontos - Ante-sala da Congregação - 23/07/2007.......... 118

Tabela 10 - PMV e PPD - 17/11/2006 ......................................................... 123

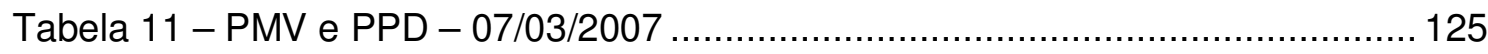

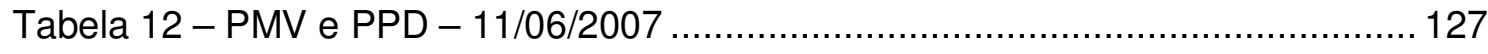

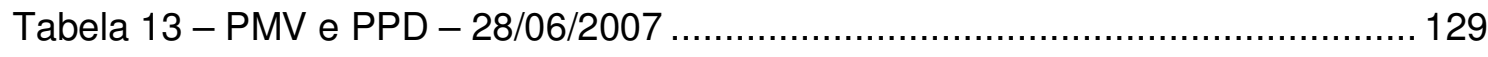

Tabela 14 - PMV e PPD - 23/11/2006 …..................................................... 131

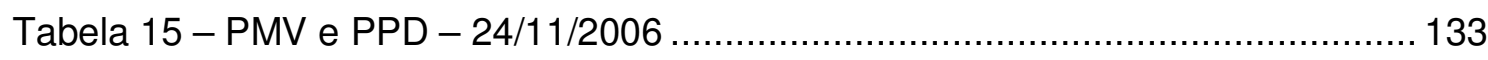

Tabela 16 - PMV e PPD - 13/03/2007 ............................................................ 135

Tabela 17 - PMV e PPD - 03/06/2007 ......................................................... 137

Tabela 18 - PMV e PPD - 07/07/2007 ........................................................ 139

Normais Climatológicas de São Carlos (1961-1990)............................................... 162

Normais Climatológicas de São Carlos (1961-1990)........................................... 162 


\section{SUMÁRIO}

1 INTRODUÇÃO

2 CONFORTO AMBIENTAL

2.1 Conforto Térmico

2.1.1 Conceitos e definições 38

2.1.2 Variáveis que influenciam o Conforto Térmico 39

2.1.3 ISO 7730/2005 42

2.2 Conforto visual $\quad 44$

2.2.1 Conceitos e definições 44

2.2.2 Fatores que influenciam a percepção visual 45

2.2.3 NBR $15215 \quad 48$

2.2.4 NBR $5413 \quad 51$

$\begin{array}{lll}2.3 & \text { Eficiência Energética } & 53\end{array}$

3 O BLOCO E1: ARQUITETURA, HISTÓRIA E TÉCNICA 57

3.1 A criação da Escola de Engenharia de São Carlos 57

$\begin{array}{ll}3.2 & 0 \text { projeto para o campus } \\ & 60\end{array}$

$\begin{array}{lll}3.3 \text { O Bloco E1 } & 65\end{array}$

3.4 A preocupação com o conforto ambiental $\quad 74$

4 MATERIAIS E MÉTODOS

$\begin{array}{lll}4.1 & \text { Questionários } & 87\end{array}$

4.2 Medições in loco 88

4.2.1 Níveis de iluminância 90

$\begin{array}{lll}\text { 4.2.2 Variáveis ambientais } & 91\end{array}$

$\begin{array}{lll}4.3 & \text { Forma de análise dos resultados } & 96\end{array}$

$5 \quad$ RESULTADOS E DISCUSSÕES $\quad 99$ 
$\begin{array}{lll}5.1 & \text { Questionários } & 99\end{array}$

5.2 Níveis de lluminância $\quad 106$

5.2.1 Ambiente: Assistência Administrativa 106

5.2.2 Ambiente: Ante-sala da Congregação 115

$\begin{array}{lll}5.3 & \text { Variáveis ambientais } & 120\end{array}$

5.3.1 Ambiente: Assistência Administrativa 122

$\begin{array}{lll}\text { 5.3.2 Ambiente: Ante-sala da Congregação } & 130\end{array}$

$\begin{array}{ll}5.4 \text { Considerações finais } & 139\end{array}$

6 CONCLUSÕES $\quad 145$

$\begin{array}{ll}\text { REFERÊNCIAS } & 149\end{array}$

APÊNDICE A - NORMAIS CLIMATOLÓGICAS: SÃO CARLOS 161

APÊNDICE B - MODELO DO QUESTIONÁRIO APLICADO 165

APÊNDICE C - TABULAÇÃO DE DADOS - VARIÁVEIS AMBIENTAIS 171 


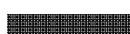

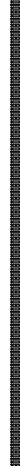




\section{INTRODUÇÃO}

A tarefa dos homens consiste em fazer com que de certas condições surjam novos pensamentos e, dos pensamentos, novas condições.

Karl Mannheim

Uma das funções da arquitetura é oferecer no interior dos edifícios condições térmicas e de iluminação compatíveis aos níveis de conforto para o ser humano, independente das condições externas. Segundo Mange (1956) uma obra deve ser criada atendendo às características fisiológicas do homem, físicas do clima e físico-geométricas de seus elementos materiais, colocandose entre o homem e o agente.

O conhecimento das exigências humanas quanto ao conforto ambiental e do clima, associado ao partido arquitetônico e às características térmicas dos materiais, proporciona condições de projetar edifícios e espaços urbanos com resultados de térmica e iluminação que atendam às exigências de conforto ambiental do ser humano.

Para se estabelecer parâmetros relativos às condições de conforto térmico é necessário considerar as variáveis ambientais (temperatura, umidade relativa, velocidade relativa do ar e temperatura de globo) e os fatores relacionados com a presença humana (atividade desenvolvida e o tipo de vestimenta utilizada). Quanto à iluminação, necessária em uma edificação para a obtenção de conforto visual, ela deve ter direcionamento adequado e intensidade suficiente, proporcionando boa definição de cores e ausência de ofuscamento. Deve permitir o desenvolvimento de tarefas visuais como a leitura, manufatura e consertos. 
A preocupação para a obtenção de conforto quanto à térmica e à iluminação de uma edificação tem sido enfatizada nas últimas décadas do século XX. E nos últimos anos, tem aumentado nos projetos de arquitetura o interesse quanto condicionamento térmico e sistemas de iluminação natural por razões não só de conforto, mas também de eficiência energética. Deve-se destacar que importante parcela do consumo total de energia elétrica em um edifício se deve aos equipamentos de climatização - seja para o aquecimento ou para a refrigeração dos ambientes - e à iluminação artificial. $O$ uso otimizado da ventilação natural, o emprego de materiais de forma adequada e o aproveitamento de luz natural em edificações usadas principalmente durante o dia, produzem uma contribuição significativa para a redução do consumo de energia elétrica, além de melhoria do conforto ambiental e bem-estar dos ocupantes. Dessa forma, o montante de energia elétrica necessária para a climatização e iluminação de um edifício depende, fundamentalmente, de seu projeto.

A edificação estudada nessa pesquisa, o Bloco E1, reflete diversas técnicas para a obtenção de conforto ambiental, tornando-se uma farta fonte de estudos para o tema e assim podendo contribuir com a ampliação e difusão de estratégias de projeto que auxiliem na obtenção de conforto ambiental e redução do consumo de energia.

Dessa forma, o objetivo geral desta pesquisa é analisar o edifício administrativo da Escola de Engenharia de São Carlos pertencente à Universidade de São Paulo, do ponto de vista do conforto ambiental, com ênfase nas soluções adotadas para a obtenção de conforto térmico e otimização da iluminação natural. Como objetivos específicos pode-se citar:

- Estudar as estratégias adotadas para obtenção de conforto, através de uma análise projetual (microclima, partidos arquitetônicos, implantação, materiais, técnicas construtivas, aberturas, envidraçamentos, diagramas e esquemas de estudo).

- Obter parâmetros das sensações dos usuários, relacionados à térmica e à iluminação natural, quanto à edificação em questão a partir da aplicação de questionários. 
- Análise e comparação dos resultados obtidos nas medições realizadas in loco com equipamentos específicos (variáveis ambientais de conforto térmico e níveis de iluminação).

- A partir de análises críticas e comparações dos resultados obtidos, contribuir para estratégias de projeto com os possíveis resultados positivos e negativos encontrados. Essas estratégias deverão visar a obtenção de conforto ambiental nas edificações e a diminuição do consumo de energia.

Para tanto, essa dissertação foi organizada em sete capítulos. No capítulo 1 - Introdução - é descrito de maneira geral o tema tratado e seus objetivos.

No capítulo 2 - Conforto Ambiental - são estabelecidas as bases teóricas da pesquisa através da atualização bibliográfica.

No capítulo 3 - O Bloco E1: Arquitetura, História e Técnica - é apresentado o objeto desta pesquisa. São tratados o histórico da criação da Escola de Engenharia de São Carlos, o projeto para o campus e o projeto para - Bloco E1. Neste capítulo é enfatizada a preocupação com as questões de conforto ambiental por parte dos autores do projeto.

No capítulo 4 - Caracterização climática: a cidade de São Carlos - é realizada uma descrição geral das características climáticas da cidade onde se situa o Bloco E1.

O capítulo 5 - Materiais e Métodos - expõe os materiais e métodos utilizados na aplicação de questionários, nas medições dos níveis de iluminância e nas medições das variáveis ambientais.

No capítulo 6 - Resultados e Discussões - são apresentados e discutidos os resultados obtidos.

No capítulo 7 - Conclusões - são mostradas conclusões e considerações finais do trabalho. 


$$
1
$$




\section{CONFORTO AMBIENTAL}

Na segunda metade do século XVIII com o desenvolvimento das cidades ocasionado pela indústria e pelo crescimento volumoso da população operária residente nos centros urbanos, a questão da ação do ambiente sobre o homem passa a ter outra interpretação. Os agentes climáticos e os espaços ocupados pelo homem deixam de serem vistos como acontecimentos independentes e passa-se a estudar a ação do homem no determinismo do microclima desses espaços.

As cidades cresceram sem infra-estrutura alguma, não havia rede de esgoto e de água, lixos e dejetos fecais eram jogados nos espaços públicos. Os operários viviam amontoados em casas grudadas, sem espaços entre elas para circulação de ar. Não possuíam pavimentação, aberturas destinadas para ventilação, e divisão de cômodos e funções. Nessas habitações privadas, onde não havia ventilação para a renovação do ar, tornou-se presente a disseminação de doenças.

Segundo Foucault (1981) nasce em grandes centros como Paris e Londres o medo urbano, medo da cidade, medo das oficinas e fábricas que estão se construindo, do amontoamento da população, das casas altas demais, da população numerosa e das epidemias urbanas.

Eis Paris! Todas essas janelas, todas essas portas, todas essas aberturas, são bocas que precisam respirar (...). Paris é uma imensa fábrica de putrefação, onde a miséria, a peste e as doenças trabalham em conjunto, onde nem o ar nem o sol penetram. Paris é um mau lugar onde as plantas definham e morrem, onde de sete crianças, morrem quatro por ano. Os médicos que entraram nos pardieiros das classes pobres 
fizeram relatos assustadores; porém os ricos já se esqueceram (Victor Considérant ${ }^{1}, 1848$ apud BRESCIANI, 1985, p. 21).

Assim, em meados do século XVIII, constitui-se a medicina moderna sob o viés da salubridade, com preocupações de ordem social. Segundo Foucault (1986):

[...] Salubridade é a base material e social capaz de assegurar a melhor saúde possível dos indivíduos. E é correlativamente a ela que aparece a noção de higiene pública, técnica de controle e de modificação dos elementos materiais do meio, que são suscetíveis de favorecer ou, ao contrário, prejudicar a saúde [...] (FOUCAULT², 1986 apud SEGAWA, 2001, p. 3).

Acreditava-se que o ar tinha uma influência direta sobre o organismo por veicular miasmas. Dessa forma, manter a qualidade do ar em uma cidade e fazer com que ele circule entre muros, casas e recintos tornou-se uma grande preocupação.

Segundo Corbin (1987), a ventilação constituiu o eixo das estratégias higienistas. Assegurar a circulação do fluído aéreo passou a ser uma grande preocupação. Acrescenta que a ventilação restaura a elasticidade e a qualidade anti-séptica do ar. Vigiar e controlar a circulação dos fluídos aéreos se torna a partir dessa descoberta uma prática constante.

O desenho do edifício deve conduzir à divisão entre as exalações pútridas e as correntes de ar fresco, da mesma forma como deve permitir a distinção entre águas puras e águas usadas (...) a cúpula e o domo transformam-se em máquinas; sua missão é aspirar os miasmas... (CORBIN, 1987, p. 130).

\footnotetext{
${ }^{1}$ CONSIDÉRANT, Victor. (1848). Description du Phalanstère et Considerations Sociales sur l' Architectonique. 2. Ed. Paris: Livraria Societária.

${ }^{2}$ FOUCAULT, M. (1986). Microfísica do poder. 6. Ed. Rio de Janeiro: Graal. p. 214.
} 
Nos anos 1840-1850, encontramos por toda parte esta exigência de adequação do desenho urbano à lógica destes elementos - o ar e a luz - e dos condutores de elementos canalizações de água e esgotos - sem esquecer o fluxo de pessoas e veículos (BEGUIN, 1991, P. 44).

Assim a busca de ventilação para renovação do ar e também para aquisição de conforto passa a influenciar os projetos de arquitetura. As intervenções higienistas buscaram criar nas casas espaços internos e recuos para possibilitar a abertura de janelas em todos os cômodos. Na busca de redefinir o espaço privado, de acordo com Correia (2004):

O interior da casa foi medicalizado e penetrado por uma
racionalidade nova, que modifica seu projeto e uso, separando
e classificando funções, ordenando, clareando, iluminando e
arejando ambientes. A intervenção na casa dá-se através de
redefinição da planta e do programa, da introdução de novos
materiais e técnicas construtivas, da difusão de utensílios e
mobiliário inéditos, da ligação das residências às recém-
construídas redes públicas de abastecimento de água e
esgotos (CORREIA, 2004, p. 28).

No Brasil, as medidas higienistas começam a ser discutidas nos últimos quinze anos do século XIX. Segundo Bonduki (1998), na cidade de São Paulo, o poder público atacou em três frentes: a do controle sanitário das habitações; a da legislação e códigos de posturas; e a participação direta em obras de saneamento das baixadas, urbanização da área central e implantação de rede de água e esgoto. Tratando-se do controle sanitário as medidas tiveram uma concepção que identificava na cidade e nas moradias as causas das doenças.

O crescimento das cidades era visto como algo que teria agravado suas condições sanitárias, aumentando o volume de lixo e de dejetos produzidos e, sobretudo, acentuando o amontoamento de edificações e indivíduos, que impedia uma ampla circulação do ar, das coisas e pessoas, e a penetração 
da luz e dos raios solares nas ruas e casas (CORREIA, 2004, p. 13).

No final do século XIX era evidente o processo de deterioração das habitações e das condições sanitárias na cidade de São Paulo. Correia (2004) relata em seu livro A construção do habitat moderno no Brasil - 1870-1950, a descrição realizada em 1893 por uma Comissão composta por um engenheiro e delegados do Serviço Sanitário a respeito do interior das casas em São Paulo. Essas habitações eram vistas "como um lugar sujo, amontoado de pessoas e coisas, desordenado e desagradável" e continua, acrescentando em sua descrição a presença de umidade e a deficiência de iluminação e ventilação:

Do ponto de vista da saúde, as dimensões reduzidas, o pouco arejamento e a escassa iluminação, provocando o amontoamento de indivíduos e coisas em espaços confinados, eram entendidos como condicionantes de um meio propício à geração de moléstias (CORREIA, 2004, p. 5,7).

Discutia-se a necessidade de criar leis e manuais que auxiliassem engenheiros e arquitetos e que seguissem as características geográficas do Brasil, considerando latitude, condições climáticas e hábitos da população. Segundo Segawa (2001) essa reivindicação por uma coerência com o meio ganha força na segunda década do século $X X$, já que até este momento as fontes de consulta eram leis pertencentes a países estrangeiros, as quais não se adaptavam aos aspectos físicos e sociais do Brasil. Com base nesse fato, o médico carioca Afrânio Peixoto (1876-1947) declara:

A casa, destinada ao abrigo, deve ser disposta segundo o regime meteorológico do meio e os costumes dos que a devem habitar. A arquitetura satisfaz estas necessidades e ajunta o supérfluo, mas já indispensável pela cultura estética, de bom gosto [...] (PEIXOTO ${ }^{3}, 1917$ apud SEGAWA, 2001, p. 6).

\footnotetext{
${ }^{3}$ PEIXOTO, A. (1917). Hygiene. 2. Ed. Rio de Janeiro: Francisco Alves. p. 286-287.
} 
Segundo Segawa (2001):

Avocar uma arquitetura apropriada segundo o clima foi uma preocupação que deve ser necessariamente relacionada com o emergir de manifestações de nacionalismo, como os discursos do engenheiro Ricardo Severo (1869-1940) em 1914 e 1917 no grêmio Politécnico de São Paulo, defendendo uma 'arte tradicional no Brasil' e o estudo da arte colonial como orientação para a 'perfeita cristalização da nacionalidade' [...] (SEGAWA, 2001, p. 6).

O engenheiro carioca Paulo Sá, segundo Segawa (2001) foi um dos pioneiros nas discussões sobre conforto térmico:

Entre nós, os que não se contentavam com repetir as regras européias ou americanas sobre o assunto, baseavam a orientação no cálculo do número mínimo de horas de insolação exigidas. Consideravam assim o problema como uma questão de mínimo a ultrapassar, mediante o fenômeno com a hora de insolação como unidade.

Ora, a fixação de um mínimo correspondente a admitir que em nosso país a ação do sol é tanto mais benéfica quanto mais prolongada. Não o será, com certeza, pelo seu efeito térmico: já que no Brasil (na parte tropical do país) há calor em excesso e o objetivo será sempre diminuí-lo quanto se possa. [...] Quanto à ação luminosa, já mostramos em outro trabalho que os iluminamentos habituais são aqui antes excessivos do que deficientes: e não há, em regra, qualquer perigo de que falte iluminação solar (a não ser em casos excepcionais, como por exemplo em prédios muito altos com as passagens absurdamente estreitas que entre eles se permitem) $\left(S^{4}, 1942\right.$ apud SEGAWA, 2001, p. 7, 8).

${ }^{4}$ SÁ, P. (1942). A orientação dos edifícios nas cidades brasileiras. Rio de Janeiro: Instituto Nacional de Tecnologia. p. 9-10. 
Em um de seus livros sobre conforto térmico, o Estudo sobre o conforto thermico no Brasil, Sá (1936) enfatiza:

A idéia da inferioridade dos povos tropicaes, condemnados, como já houve quem dissesse recentemente, 'pela própria ordem cósmica das cousas, a uma pérpetua servidão', pode ser destruída, de uma vez para todas, quando a technica e o engenho humanos conseguirem, como vem conseguindo a pouco e pouco, crear em cada local o clima mais adaptado às condições de vida que nelle se encontram.

Preliminar, porém, a todo esse estudo, é com certeza justamente a questão de determinar quaes estas condições optimas do ambiente em cada região do globo, para cada typo de homem, para cada gênero de actividade (SÁ, 1936, p. 7).

Segawa (2001) também destaca em seu artigo Clave de Sol o médico pernambucano Aluízio Bezerra Coutinho, que em 1929 apresentou a tese $O$ problema da habitação hygienica nos paizes quentes em face da 'Architectura Viva' na Faculdade de medicina do Rio de Janeiro. Nessa tese Bezerra cita arquitetos modernos como Le Cobusier e propõe uma adequação da arquitetura brasileira às condições climáticas, sugere a união entre novos materiais e técnicas (frente à necessária proteção ao excesso de calor) e a estética corbusieriana.

Para Segawa (2001) técnicos como Paulo Sá estão associados à "constituição de uma disciplina de conforto ambiental como entendemos hoje, de raiz racionalista e fundamentada nos preceitos da arquitetura moderna". E continua:

A 'arte da aclimatação', em especial nos trópicos úmidos, parece uma crônica de disparates. No passado, procurava-se esquivar da corrente do ar, evitando o temeroso miasma, e a ventilação seria a forma de controlar a insalubridade, como 
defendia Schreiner ${ }^{5}$; depois, renovar o ar se tornou a palavra de ordem, e ventilar uma maneira de proporcionar alívio. Antes, buscava-se a máxima insolação para tirar proveito da assepsia promovida pêlos raios solares; depois, o problema se tornou 0 'excesso de sol nos aposentos', [...]. Afrânio Peixoto tolerava na arquitetura 'ajuntar o supérfluo' - a cultura estética, o bom gosto' - desde que a casa obedecesse ao 'regime meteorológico'. Paulo Sá - com todo cuidado de relativizar os termos - propugnava uma maior atenção as considerações de conforto, defendendo a 'máquina de morar' no lugar do 'quadro para ver'. Era a proposição do 'certo' - o conforto -, superando o 'incerto' - o belo. Superar essas falsas dualidades é um esforço ainda inconcluso (SEGAWA, 2001, p. 10,11).

Diante desse discurso defendido por Segawa (2001) podemos citar como exemplo de associação entre arquitetura e condições climáticas o engenheiro civil Ernesto Roberto de Carvalho Mange. Ele foi estagiário de Le Corbusier, portanto adepto do Movimento Moderno, mas preocupado com a coerência entre estética e clima. Mange é autor de vários textos que discutem essas questões, também fez várias experimentações em suas obras, entre elas destaca-se o Bloco E1 (objeto desta pesquisa).

Em sua tese $A$ função abrigo em arquitetura Mange (1956) realiza uma discussão sobre as diversas funções de uma edificação, designando como uma das principais a "função abrigo", já que uma das necessidades básicas do ser humano é proteger-se em relação aos agentes físico-climatológicos.

Inicia sua discussão referindo-se ao projeto arquitetônico como o resultado em organizar um espaço, o qual pode ser dividido em espaço interior e espaço exterior. A isso associa as características físico-geométricas dos materiais utilizados, que devem ser selecionados a fim de criarem, na medida do possível, um microclima propício à vida humana (figura 1).

\footnotetext{
${ }^{5}$ Luiz Schreiner (1938-92) foi engenheiro-arquiteto formado na Real Academia de Belas-Artes de Berlim. Segundo Segawa (2001) é (possivelmente) autor da primeira publicação editada no Brasil sobre a questão da ventilação, Estudos sobre ventilação em geral e na sua applicação a escolas, hospitaes, theatros, salas de reuniões grandes, habitações, etc., datada de 1878.
} 
Assim, define a obra de arquitetura como um "'envoltório material' que visa atender, em todos os sentidos, às necessidades da vida humana, envoltório esse seletivo-corretivo." (p. 21).

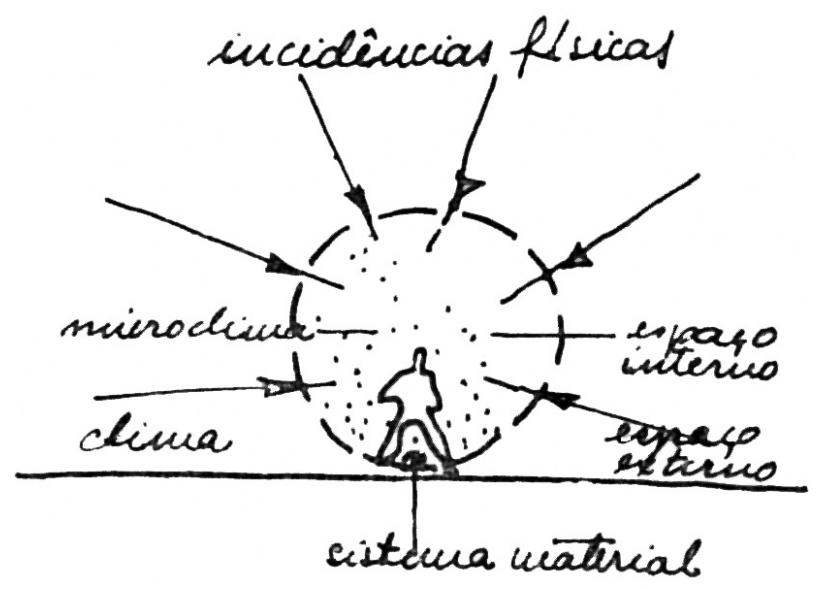

Figura 1 - Esquema desenvolvido por Mange

Fonte - MANGE (1956)

Considerando essas relações entre espaços interno e externo, acrescenta:

O invólucro deverá ser criado atendendo às características fisiológicas do Homem, às características físicas do clima e as próprias características físico-geométricas de seus elementos materiais. A obra coloca-se entre o Homem e o agente: será concebida com base nos conhecimentos desses fatores, ou seja, com base no conhecimento das leis do fenômeno físicofisiológico em questão (Mange, 1956, p. 22-23).

Finaliza a sua análise considerando que a própria vida humana e a presença de equipamentos no interior de uma edificação trazem novas condições físicas.

Após apresentar a "função abrigo", Mange (1956) discute a sua importância e o seu significado: 
Certamente é necessário evitar a chuva e o sol excessivo, e ninguém 0 discute. Porém hoje para realizarmos obra realmente atual é necessário bem mais que isso. [...]

É ponto pacífico que o estudo criterioso do Homem e do ambiente psicológico e material que o cercam promovem medidas que trazem condições mais adequadas ao trabalho, comprovadas pelo seu alto rendimento [...]

Ora, dentre as medidas teoricamente estudadas e praticamente realizadas destacam-se aquelas referentes ao condicionamento correto do ambiente físico-fisiológico ao trabalho $[\ldots]$

O aperfeiçoamento do microclima interno é ponto fundamental do programa das ciências aplicadas que se dedicam ao estudo do homem e suas condições de trabalho (MANGE, 1956, p. 4142).

Nessa análise de Mange (1956) é possível entender a importância do projeto arquitetônico para as construções, sendo apontados alguns fatores que devem ser considerados para que estas possuam ambientes termicamente confortáveis. Cita os agentes climáticos, as características físico-geométricas de materiais, as características fisiológicas do homem e ainda as interferências que o próprio homem e equipamentos trazem para o ambiente interno.

Contudo, já na década de 1960, seguinte à construção do Bloco E1, segundo Scarazzato (1988), com a abertura do Brasil ao capital estrangeiro e a decorrente influência das multinacionais, ocorreu um retrocesso nas questões ambientais. Foi muito marcante a "imposição de modelos construtivos alheios à realidade nacional-econômica, tecnológica e mesmo climática". Segue afirmando que a partir da segunda metade da década de 1970, o estudo de conforto ambiental vai ganhando impulso. $E$ nas últimas décadas têm se intensificado os estudos sobre os fatores que devem ser atendidos a fim de que o homem sinta-se termicamente confortável em um ambiente. Nessas 
discussões enquadram-se as funções da arquitetura, preocupações e orientações para arquitetos.

Segundo Lamberts e Xavier (2002), a importância dos estudos atuais que buscam a obtenção de conforto térmico está baseada, principalmente, em três fatores:

- O bem estar do homem;

- A performance humana;

- A conservação de energia.

Estudos mostram, por exemplo, que o desconforto causado por frio ou calor pode diminuir o rendimento de atividades realizadas pelo homem. A figura 2 indica uma relação entre número de acidentes de trabalho e temperatura do ambiente:

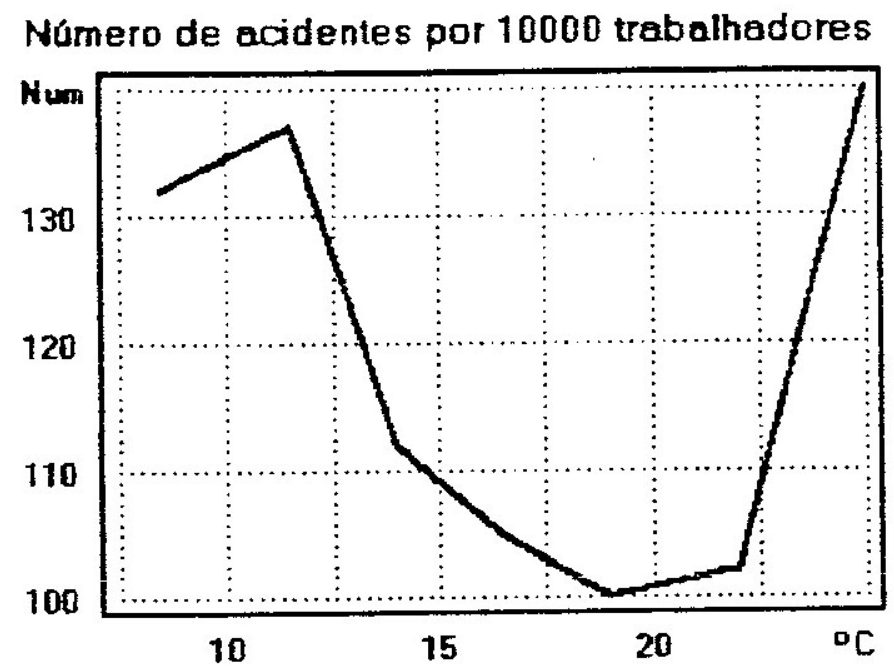

Figura 2 - Relação entre $n^{0}$ de acidentes de trabalho e temp. do ambiente Fonte - EDHOLM ${ }^{6}$ (1968 apud RORIZ, 2001, p. 3)

Como exemplo de arquitetos atuais que consideram as questões ambientais em seus projetos e preocupam-se com regionalismos podemos destacar João Filgueiras Lima (Lelé) e Severiano Porto.

João Filgueiras Lima ficou conhecido por soluções estruturais criativas e altamente elaboradas, tanto para equipamentos de infra-estrutura das cidades quanto para diversos tipos de edifícios. Utiliza componentes industrializados de

${ }^{6}$ EDHOLM, O. G. (1968). A Biologia do Trabalho. Porto: Editorial Nova Limitada. p. 3. 
aço, plástico e argamassa armada. Segundo RECAMÁN (2005) preocupa-se com a racionalização das técnicas e a industrialização dos componentes construtivos, com a melhoria das condições urbanas de saneamento e circulação e com a busca de soluções de conforto ambiental mais apropriadas às condições brasileiras. É considerado um dos maiores especialistas em projetos de hospitais. É de sua autoria os hospitais pertencentes à rede SARAH , a qual é constituída por cinco unidades hospitalares localizadas em Brasília (DF), Salvador (BA), São Luís (MA), Fortaleza (CE) e Belo Horizonte (MG). Prestam serviços de ortopedia e de reabilitação.

Nesses projetos há a preocupação com a humanização e acessibilidade dos espaços, com o conforto ambiental e com a diversificação da préfabricação. Utiliza cobertura com estrutura metálica leve e contínua, formando ondulações que vão caracterizar o conjunto de todas essas edificações. Possuem sistema natural de refrigeração, que é realizado através de captação do ar por galerias, sugado pelos "sheds" para o exterior.

Os projetos de Severiano Porto possuem a idéia de regionalismo ecoeficiente. Suas concepções abrangem a adequação da arquitetura ao lugar e a racionalidade construtiva em vista da economia de meios. Realizou grande parte de suas obras em Manaus, situada em uma região muito específica: a Amazônia. É uma cidade com presença de floresta, rios e chuvas intensas. Caracterizada pelo clima quente e úmido, a incidência dos raios solares sobre o plano horizontal ao meio-dia é quase perpendicular durante todo o ano, gerando temperaturas muito altas. O relevo predominante, planície, e a baixa velocidade dos ventos intensificam o aquecimento. A intensa nebulosidade ao longo do ano, no entanto, faz com que a amplitude térmica diária seja relativamente pequena.

Em regiões como a da Amazônia é necessário proteger a edificação do acúmulo de calor, das chuvas constantes, do sol, dos insetos, e otimizar a ventilação natural. "A Amazônia, por suas peculiaridades ambientais, é capaz de induzir à formulação de uma arquitetura específica, necessariamente em diálogo com o meio". (SEGAWA, 1997, p. 193). Para Severiano, produzir uma arquitetura com consciência dos limites e das imposições do ambiente é utilizar esses elementos como desafio para buscar soluções criativas e inovadoras. 
A formação de uma consciência da existência de dependências entre arquitetura, condições físico-climaticas e aspectos sociais vem sendo desenvolvida até os dias atuais. Ao longo da história houve avanços e retrocessos, contudo há muito a se discutir e a se desenvolver em relação ao tema, principalmente considerando a sua relevância nos dias atuais.

\subsection{Conforto Térmico}

\subsubsection{Conceitos e definições}

Existem na literatura vários conceitos e definições para o termo conforto térmico, todos buscando expressar as sensações de um indivíduo quando este está termicamente confortável em um ambiente. Segundo Lamberts, Dutra e Pereira (2004, p. 41): "Se o balanço de todas as trocas de calor a que está submetido o corpo for nulo e a temperatura da pele e suor estiverem dentro de certos limites, pode-se dizer que o homem sente conforto térmico". Com base neste conceito um termo comumente utilizado nas definições de conforto térmico é neutralidade térmica.

Segundo Fanger (1970) "Neutralidade térmica é a condição na qual uma pessoa não prefira nem mais calor nem mais frio no ambiente a seu redor". Ou ainda, uma definição mais recente de neutralidade térmica:

\footnotetext{
Estado físico, no qual todo o calor gerado pelo organismo através do metabolismo, seja trocado em igual proporção com o ambiente ao redor, não havendo nem acúmulo de calor, nem perda excessiva do mesmo, mantendo a temperatura corporal constante (LAMBERTS; XAVIER, 2002, p. 3).
}

Por diversos estudos e definições como estas, chega-se que o conforto térmico depende de variáveis físicas e pessoais, as quais serão apresentadas a seguir. 


\subsubsection{Variáveis que influenciam o Conforto Térmico}

A busca de conforto térmico nas edificações envolve fenômenos cuja compreensão implica, entre outros fatores, estudos dos processos de sensações térmicas dos usuários, análise do clima local e de cada uma de suas variáveis, e conhecimento dos mecanismos de transmissão de calor.

Segundo Koenigsberger et al. (1977), os critérios para o conforto total em um ambiente dependem de todos os sentidos do homem. A resposta humana ao ambiente térmico depende dos processos básicos do ser humano.

O corpo humano utiliza a energia dos alimentos ingeridos para a realização de qualquer trabalho, processo designado metabolismo, o qual pode ser dividido em metabolismo basal, que é a energia consumida pelo corpo quando ele está em repouso, e em metabolismo muscular, que é a situação em que o corpo está executando alguma atividade e os músculos estão produzindo calor. Dessa forma, o calor produzido através dos processos metabólicos do ser humano ocorre em função da atividade desempenhada.

Contudo a temperatura do corpo deve permanecer constante em aproximadamente $37^{\circ} \mathrm{C}$ e para que isso ocorra, o calor excedente deve ser dissipado para o ambiente. A situação inversa também deve ser evitada, que é quando o ambiente retira do corpo uma quantidade de calor maior que a que ele produz. Assim se essas trocas de calor entre o homem e o ambiente estão aumentando ou diminuindo a temperatura do corpo humano, podem ocorrer problemas de saúde e/ou consideráveis perdas de eficácia em trabalhos executados.

Assim o fato de o homem sentir-se termicamente confortável dentro de um ambiente engloba uma série de variáveis, as quais podem se divididas em variáveis ambientais ou físicas e variáveis pessoais ou individuais, e deve-se ainda considerar as variáveis subjetivas. Dentre essas variáveis alguns estudos realizados em câmaras climatizadas mostram que a principais são:

- Temperatura do ar $\left({ }^{\circ} \mathrm{C}\right)$

- Temperatura radiante média $\left({ }^{\circ} \mathrm{C}\right)$

- Velocidade do ar $(\mathrm{m} / \mathrm{s})$

- Umidade do ar (\%)

- Atividade desenvolvida (met) 
- Vestimenta utilizada (clo)

\section{A. Variáveis físicas ou ambientais:}

\section{- Temperatura do ar:}

Segundo Roriz (2001, p. 41), "é a temperatura do ar 'à sombra". Essa variável influencia nas trocas de calor por convecção entre o corpo humano e o ambiente.

\section{- Temperatura radiante média:}

"Temperatura uniforme de um ambiente imaginário no qual a troca de calor do corpo humano por radiação é igual a troca de calor por radiação no ambiente real não uniforme" (ABNT NBR 15220-1, 2005, p.4).

Segundo Labaki em um artigo publicado na revista Pesquisa Fapesp:

Temperatura radiante média é o valor médio entre a radiação térmica que incide sobre as superfícies do local - objetos e seres vivos -, e as aquece, e a radiação que elas emitem de volta para o ambiente. Esse valor dá uma indicação dos efeitos da radiação térmica sobre a pessoa, pois há diferenças significativas de temperatura entre as superfícies circundantes no caso de áreas externas, são as próprias árvores, a grama, o pavimento e as construções em torno. Um exemplo da importância desse parâmetro é o de uma multidão reunida em praça pública num dia de sol: embora a temperatura ambiente seja a mesma nas laterais e no interior da praça, quem está no centro da multidão sente mais calor - porque, além da radiação solar e da radiação refletida pela área cimentada do local, recebe o calor emitido pelos corpos ao redor (FIORI, 2001)

\section{- Velocidade do ar:}

Essa variável possui grande instabilidade, já que muda em função de velocidade e direção. Influencia nas transferências de calor por convecção e evaporação. Segundo Rivero (1985), um movimento de ar 
da ordem de $1,5 \mathrm{~m} / \mathrm{s}$ ocasiona em uma pessoa a sensação térmica de diminuição de $3^{\circ} \mathrm{C}$.

\section{- Umidade relativa do ar:}

"Quociente da umidade absoluta do ar pela umidade absoluta do ar saturado para a mesma temperatura e pressão atmosférica" (ABNT NBR 15220-1, 2005, p.5).

Deve-se haver um equilíbrio nos valores dessa variável, não podem ser muito baixos, pois podem causar ressecamento das mucosas, nem muito altos, pois podem causar condensação superficial e em climas muito quentes dificultam a evaporação do suor.

\section{B. Variáveis pessoais ou individuais:}

- Atividade desenvolvida:

De acordo com a atividade desempenhada por uma pessoa há uma variação em seu metabolismo. Existem diversas tabelas que estimam a taxa metabólica de acordo com a atividade desempenhada. Quanto maior for a atividade física, maior será o calor gerado pelo metabolismo. Dessa forma, em um projeto de arquitetura devem-se considerar as possíveis atividades que serão desenvolvidas no local. A unidade dessa variável é met, sendo que 1 met equivale a $58,2 \mathrm{~W} / \mathrm{m}^{2}$.

\section{- Vestimenta utilizada:}

A vestimenta influencia nas trocas de calor por convecção entre o corpo humano e o ambiente. $\mathrm{O}$ isolamento térmico das roupas proporciona certas resistências a essas trocas de calor. Os valores desse isolamento térmico variam em função dos materiais utilizados na confecção das roupas (tipo do tecido e fibra) e do seu ajuste ao corpo. A unidade dessa variável é clo, sendo que 1 clo equivale a $0,155 \mathrm{~m}^{2}{ }^{\circ} \mathrm{C} / \mathrm{W}$. 


\section{Variáveis subjetivas:}

- Idade:

O metabolismo basal de uma pessoa vai diminuindo conforme a idade vai avançando. Esse fato leva os idosos, conforme demonstrado em experimentos, a preferirem ambientes mais quentes que os jovens.

\section{- Sexo:}

As mulheres possuem uma taxa metabólica um pouco mais baixa que a dos homens, o que as levam a preferirem temperaturas mais altas as dos homens.

\section{- Forma do corpo}

A relação entre o peso e a altura de uma pessoa influencia nas condições de conforto térmico. Alguns estudos mostram que pessoas obesas tendem a preferir ambientes mais frios quando desempenham atividades que envolvem movimentos, isso por razão da taxa metabólica ser mais elevada nessas situações.

\subsubsection{ISO $7730 / 2005$}

A ISO 7730/2005 - Ergonomics of the thermal environment - Analytical determination and interpretation of thermal comfort using calculation of the PMV and PPD indices and local thermal comfort criteria apresenta métodos para prever sensação térmica e grau de desconforto de pessoas expostas a ambientes térmicos moderados. Permite a determinação analítica e interpretação de conforto térmico utilizando o cálculo de PMV (voto médio estimado) e PPD (percentagem de pessoas insatisfeitas) e critérios locais de conforto térmico. A norma aplica-se a homens e mulheres saudáveis situados em ambientes internos onde o conforto térmico é desejado. Embora seja desenvolvida especificamente para ambientes de trabalho, também é aplicável a outros tipos de ambientes.

O PMV é um índice que prevê o valor médio dos votos de um grupo grande de pessoas na escala de sensação térmica de sete pontos (ver tabela 
1), baseado no balanço térmico do corpo humano. O balanço térmico é obtido quando a produção interna de calor no corpo é igual a perda de calor para o ambiente. Em um ambiente moderado, o sistema termo-regulador humano tenta automaticamente modificar a temperatura da pele e a transpiração para manter o balanço térmico.

\section{Tabela 1 - Escala de sensação térmica de sete pontos}

\begin{tabular}{|c|l|}
\hline+3 & Muito quente \\
\hline+2 & Quente \\
\hline+1 & Levemente quente \\
\hline 0 & Neutro \\
\hline-1 & Levemente frio \\
\hline-2 & Frio \\
\hline-3 & Muito frio \\
\hline
\end{tabular}

O PMV pode ser calculado para diferentes combinações de taxas metabólicas, tipos de vestimentas, temperatura do ar, temperatura radiante média, velocidade do ar e umidade do ar.

Pode-se determinar o PMV de diferentes formas:

a. A partir de equações com o auxílio de softwares;

b. A partir de tabelas de valores de PMV baseadas em combinações de atividade metabólica, tipo de vestimenta, temperatura e velocidade;

c. Medição direta, utilizando um sensor integrado.

Quando o PMV é igual a zero significa que a combinação entre atividade, vestimenta e parâmetros ambientais promovem, na média, uma sensação térmica neutra.

O PPD é um índice, gerado a partir do PMV (figura 3), que estabelece uma previsão quantitativa da percentagem de pessoas insatisfeitas termicamente. São consideradas pessoas termicamente insatisfeitas aquelas que votariam muito quente, quente, frio ou muito frio na escala de sensação térmica de sete pontos mostrada na tabela 1. As pessoas satisfeitas votariam levemente quente, neutro ou levemente frio. 


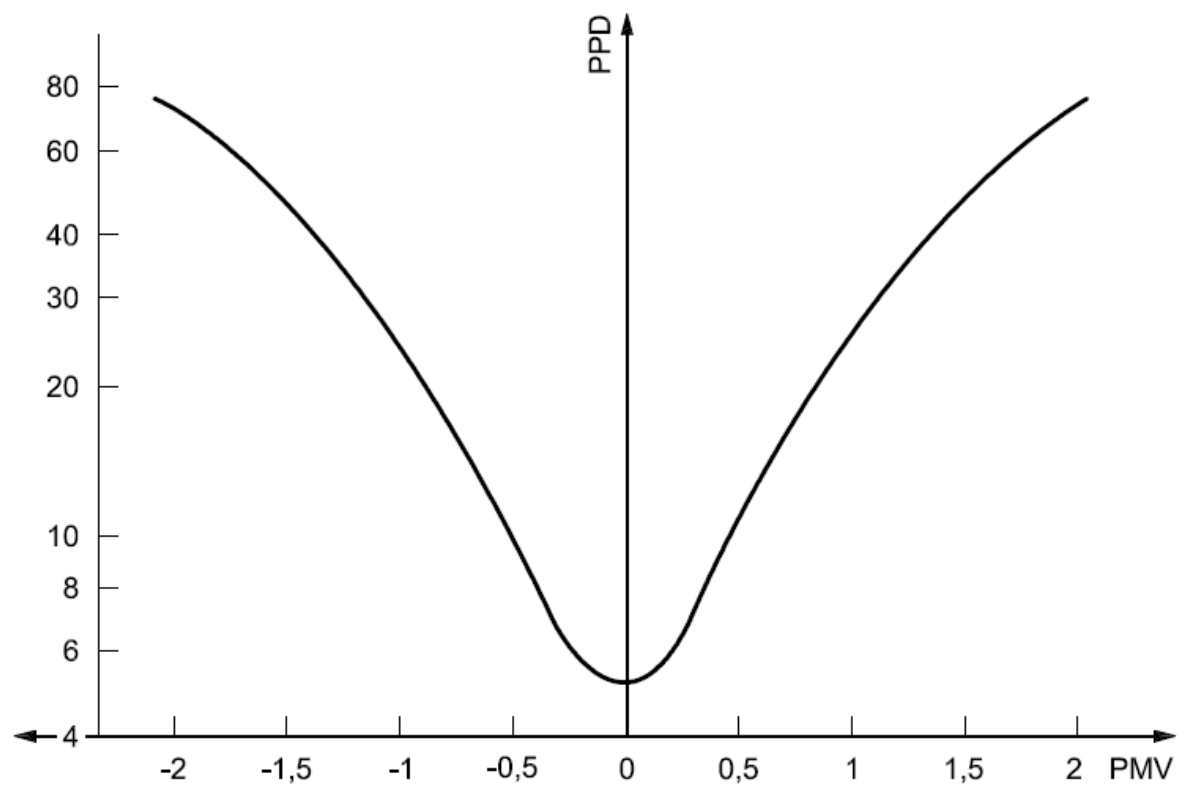

Figura 3 - PPD em função do PMV

Fonte - INTERNATIONAL ORGANIZATION FOR STANDARDIZATION $(2005$, p. 3)

Legenda:

PMV - voto médio estimado

PPD - percentagem de pessoas insatisfeitas (\%)

\subsection{Conforto visual}

Ao criar o "invólucro seletivo-corretivo"7 o homem busca selecionar, dentre os agentes, os que lhe convém, procurando eliminar aqueles que the são nocivos. Dentre os agentes físicos que não procura eliminar mas, dosar adequadamente às suas necessidades, está a luz, ou seja, as radiações solares visíveis (MANGE, 1956, p. 33).

\subsubsection{Conceitos e definições}

Conforto visual é entendido como a existência de um conjunto de condições, num determinado ambiente, no qual o ser humano pode desenvolver suas tarefas visuais com o máximo

\footnotetext{
${ }^{7} \mathrm{O}$ autor refere-se a 'invólucro seletivo-corretivo' como uma edificação.
} 
de acuidade e precisão visual, com o menor esforço, com menor risco de prejuízos à vista e com reduzidos riscos de acidentes (LAMBERTS; DUTRA; PEREIRA, 2004, p. 44).

O conforto visual em um ambiente está diretamente relacionado, entre outros fatores, com a tarefa visual que se desenvolve neste, sendo importante em todos os tipos de ambientes, como trabalho, lazer e residência. Para cada tarefa é necessário um conjunto de condições específicas, as quais são responsáveis pela intensidade do esforço físico que o olho de um ser humano fará para desempenhar com qualidade uma tarefa. Se considerado o conforto proporcionado apenas pela luz natural, este vem acompanhado de um bemestar muito maior que aquele proporcionado por uma iluminação artificial na medida em que o contato com o meio externo pode trazer grande satisfação.

\subsubsection{Fatores que influenciam a percepção visual}

Existem dois aspectos relacionados com o conforto visual de edificações que se busca obter: a garantia de uma iluminação suficiente para a realização de trabalhos com eficiência e a garantia de um ambiente visual agradável. Segundo Hopkinson; Petherbridge e Longmore (1966) um projeto de iluminação deve colocar a realização de trabalhos visuais de forma eficiente como primeiro requisito, porém devem existir métodos para determinar as quantidades de luz necessárias para desempenhar tarefas visuais com eficácia e garantir um ambiente visualmente confortável. Os parâmetros básicos seriam - Fator de Luz do Dia, que representa a quantidade de luz natural que chega ao plano de trabalho e o Índice de Encandeamento, que representa fatores físicos como dimensões das janelas e brilho do céu.

É evidente, que o estabelecimento de uma luz adequada para um trabalho visualmente eficiente é o primeiro requisito para um projecto de iluminação, mas se este critério quantitativo é assegurado apenas à custa de encadeamento excessivo e desconforto visual, o resultado não será considerado satisfatório pelo utente. 
É para esta razão que devem existir métodos, não apenas para computar as quantidades necessárias de luz em função da dificuldade visual das tarefas, mas também para determinar, numericamente, os factores que indicam se um ambiente será visualmente confortável (HOPKINSON; PETHERBRIDGE; LONGMORE, 1966, p. 4).

Para Vianna e Gonçalves (2001) os fatores que devem ser considerados na realização de tarefas visuais são:

- A vista e a visão;

- A tarefa visual que o indivíduo vai desenvolver;

- O campo visual do homem;

- Nível de iluminância;

- Luminância e contraste;

- Ofuscamento.

- A vista e a visão (Vianna; Gonçalves, 2001):

As características da vista do ser humano influenciam na qualidade da visão. Uma visão de boa qualidade depende de propriedades do olho como:

- Seletividade: a retina, responsável por receber as impressões de luz, é sensível às radiações somente na faixa entre 0,380 e 0,780 microns.

- Maior e menor sensibilidade: o olho possui sensibilidades diferentes dependendo do comprimento de onda, sendo a maior sensibilidade para as cores amarelo-esverdeado e a menor para as cores roxo e violeta.

- Percepção das cores: essa propriedade está relacionada com a sensação causada pelos diversos comprimentos de onda entre 0,380 e 0,780 microns.

- Acomodação: o olho possui a capacidade de adaptar-se às diferentes distâncias de um objeto a ele.

- Acuidade: capacidade em reconhecer detalhes de objetos. 
- Cores: os olhos possuem sensibilidade às cores e às diferentes luminosidades destas.

- Adaptação: através dessa propriedade o olho pode ajustar-se às diferentes luminâncias dos objetos.

\section{- A tarefa visual que o indivíduo vai desenvolver:}

Quanto mais complicada a tarefa a ser executada, maior deverá ser o nível de iluminação do ambiente. O nível de dificuldade de uma tarefa pode ser medido através dos detalhes que deverão ser distinguidos, do tempo de duração e da velocidade necessária na tarefa.

- O campo visual do homem (Vianna; Gonçalves, 2001):

O homem possui um campo visual de, aproximadamente, $130^{\circ}$ no sentido vertical e $180^{\circ}$ no sentido horizontal.

\section{- Nível de iluminância}

O nível de iluminância (lux) ou nível de iluminação adequado para um ambiente é muito variável, mas de modo geral, conforme o grau de dificuldade de uma tarefa visual a ser desempenhada em um ambiente, maior deverá ser o nível de iluminância. A idade da pessoa também pode influenciar, pessoas com idades avançadas exigem níveis altos de iluminância.

\section{- Luminância}

O entendimento do conceito luminância $\left(\mathrm{cd} / \mathrm{m}^{2}\right)$ é muito complexo, mas segundo Vianna e Gonçalves (2001):

É importante que se lembre do fato de que os raios luminosos não são visíveis, a sensação de luminosidade é decorrente da reflexão desses raios por uma superfície. Essa luminosidade, então vista, é chamada de luminância.

Uma vez que os objetos possuem diferentes capacidades de reflexão da luz, fica compreendido que uma certa iluminância 
pode gerar diferentes luminâncias (VIANNA; GONÇALVES, 2001, p. 71).

\section{- Contraste}

Pode ser definido como a diferença entre as luminâncias de um objeto e a de seu entorno. Não possui unidade.

\section{- Ofuscamento}

O ofuscamento é um desconforto ou perturbação causada na visão quando não acontece normalmente a adaptação às diferentes luminâncias dos objetos. Pode ocorrer devido a contrastes excessivos de luminâncias. Os ofuscamentos podem impedir o desenvolvimento da tarefa visual ou apenas causar um desconforto sem impedir a tarefa.

\subsubsection{NBR 15215}

As normas NBR 15215-1 lluminação natural - Parte 1: Conceitos básicos e definições, NBR 15215-2 lluminação natural - Parte 2: Procedimentos de cálculo para a estimativa da disponibilidade de luz natural, NBR 15215-3 lluminação natural - Parte 3: Procedimentos de cálculo para a determinação da iluminação natural em ambientes internos, e NBR 15215-4 lluminação natural - Parte 4: Verificação experimental das condições de iluminação interna de edificações - Método de medição integram o conjunto de normas que tem por objetivo apresentar dados, técnicas e informações básicas para ajudar os profissionais envolvidos no projeto de edificações a lidar com questões relacionadas à iluminação natural destes. Para tanto, disponibiliza-se métodos de cálculo e de verificação dos níveis de iluminação natural no interior das edificações.

A parte 4 deste conjunto de normas prescreve métodos para a verificação experimental das condições de iluminância de ambientes internos. Indica que as medições dos níveis de iluminância sejam feitas considerando os pontos descritos a seguir: 
a) considerar a quantidade de luz no ponto e no plano onde a tarefa for executada, seja horizontal, vertical ou em qualquer outro ângulo;

b) manter o sensor paralelo à superfície a ser avaliada ou deixá-lo sobre a superfície cujos níveis de iluminação estão sendo medidos;

c) atentar para o nivelamento da fotocélula quando ela não for mantida sobre a superfície de trabalho e sim na mão da pessoa que faz as medições, pois pequenas diferenças na posição podem acarretar grandes diferenças na medição;

d) evitar sombras sobre a fotocélula, acarretada pela posição de pessoas em relação a ela, a não ser que seja necessário para a caracterização de um posto de trabalho;

e) verificar, sempre que possível, o nível de iluminação em uma superfície de trabalho, com e sem as pessoas que utilizam estes ambientes em suas posições, desta forma, é possível verificar eventuais falhas de layout;

f) expor a fotocélula à luz aproximadamente cinco minutos antes da primeira leitura, evitando-se sua exposição a fontes luminosas muito intensas, como por exemplo, raios solares;

g) realizar as medições num plano horizontal a $75 \mathrm{~cm}$ do piso quando a altura da superfície de trabalho não é especificada ou conhecida.

Para a avaliação de iluminância em postos de trabalho devem-se fazer medições em uma quantidade de pontos suficiente para uma caracterização adequada do ambiente. Para determinar o número mínimo de pontos necessários recomenda-se calcular o Índice do Local $(\mathrm{K})$ pela expressão:

$$
K=\frac{C \cdot L}{H_{m} \cdot(C+L)}
$$

Onde:

$L$ é a largura do ambiente, em metros $(m)$;

C é o comprimento do ambiente, em metros $(\mathrm{m})$; 
$\mathrm{H}_{\mathrm{m}}$ é a distância vertical entre a superfície de trabalho e o topo da janela, em metros. (figura 4).

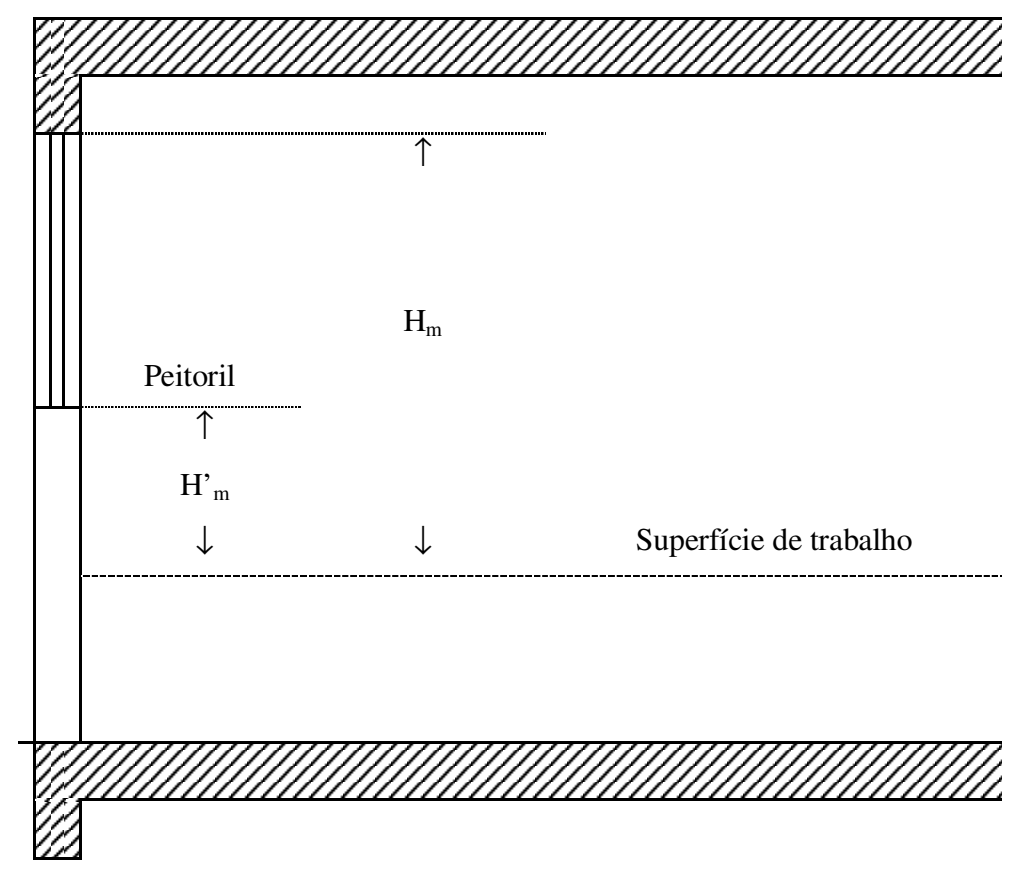

Figura 4 - Determinação de $\mathrm{H}_{\mathrm{m}}$

Fonte - ASSOCIAÇÃO BRASILEIRA DE NORMAS TÉCNICAS (2005, p. 6)

Com o valor de $\mathrm{K}$, pode ser verificada na tabela 2 a quantidade mínima de pontos a serem medidos. Dessa forma deve-se dividir o ambiente em áreas iguais, com formato próximo a um quadrado. A iluminância deve ser medida no centro de cada área. Para evitar pontos muito próximos às paredes recomenda-se um afastamento mínimo de 0,50 m destas (figura 5).

Tabela 2 - Quantidade mínima de pontos a serem medidos

\begin{tabular}{|c|c|}
\hline $\mathrm{K}$ & № de Pontos \\
\hline $\mathrm{K}<1$ & 9 \\
\hline $1 \leq \mathrm{K}<2$ & 16 \\
\hline $2 \leq \mathrm{K}<3$ & 25 \\
\hline $\mathrm{K} \geq 3$ & 36 \\
\hline
\end{tabular}




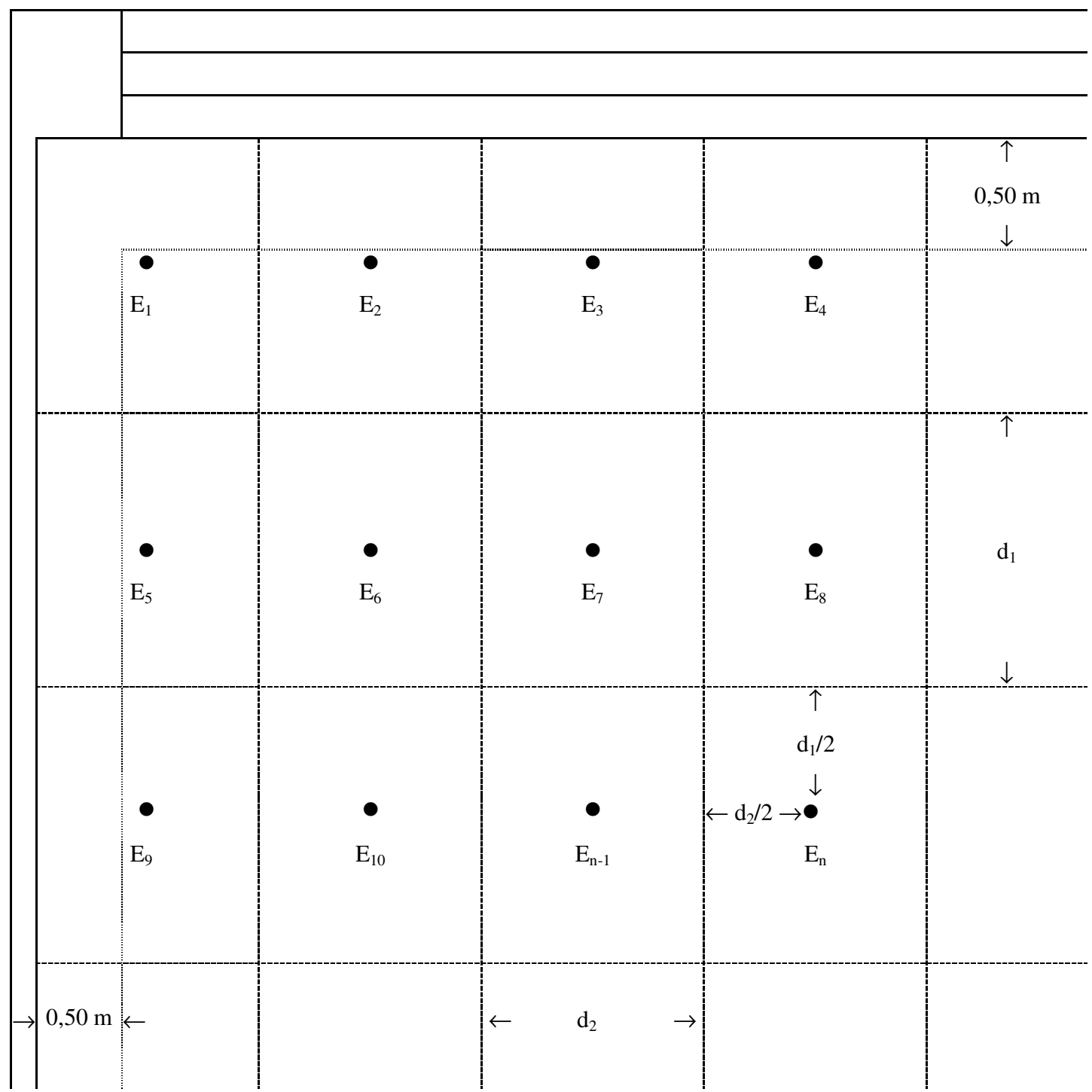

Figura 5 - Exemplo de malha de pontos para medições

Fonte - ASSOCIAÇÃO BRASILEIRA DE NORMAS TÉCNICAS (2005, p. 7)

\subsubsection{NBR 5413}

A NBR 5413 - lluminância de interiores de abril de 1992 estabelece valores de níveis de iluminâncias para diferentes tarefas visuais. A tabela 3 é apresentada nessa norma como referência: 
Tabela 3 - Iluminâncias por classe de tarefas visuais

\begin{tabular}{|c|c|c|}
\hline Classe & $\begin{array}{l}\text { Iluminância } \\
\qquad \text { (lux) }\end{array}$ & Tipo de atividade \\
\hline \multirow{4}{*}{$\begin{array}{l}\text { A } \\
\text { Iluminação geral para áreas } \\
\text { usadas interruptamente ou } \\
\text { com tarefas visuais simples }\end{array}$} & $20-30-50$ & Áreas públicas com arredores escuros \\
\hline & $50-75-100$ & Orientação simples para permanência curta \\
\hline & $100-150-200$ & $\begin{array}{l}\text { Recintos não usados para trabalho contínuo; } \\
\text { depósitos }\end{array}$ \\
\hline & $200-300-500$ & $\begin{array}{l}\text { Tarefas com requisitos visuais limitados, } \\
\text { trabalho bruto de maquinaria, auditórios }\end{array}$ \\
\hline \multirow{2}{*}{$\begin{array}{l}\text { B } \\
\text { Iluminação geral } \\
\text { para área de trabalho }\end{array}$} & $500-750-1000$ & $\begin{array}{l}\text { Tarefas com requisitos visuais normais, trabalho } \\
\text { médio de maquinaria, escritórios }\end{array}$ \\
\hline & $1000-1500-2000$ & $\begin{array}{l}\text { Tarefas com requisitos especiais, gravação } \\
\text { manual, inspeção, indústria de roupas }\end{array}$ \\
\hline \multirow{3}{*}{$\begin{array}{l}\text { C } \\
\text { Iluminação adicional } \\
\text { para tarefas visuais } \\
\text { difíceis }\end{array}$} & $2000-3000-5000$ & $\begin{array}{l}\text { Tarefas visuais exatas e prolongadas, eletrônica } \\
\text { de tamanho pequeno }\end{array}$ \\
\hline & $5000-7500-10000$ & $\begin{array}{l}\text { Tarefas visuais muito exatas, montagem de } \\
\text { microeletrônica }\end{array}$ \\
\hline & $10000-15000-20000$ & Tarefas visuais muito especiais, cirurgia \\
\hline
\end{tabular}

Fonte - ASSOCIAÇÃO BRASILEIRA DE NORMAS TÉCNICAS (1992, p. 2)

Nota: As classes, bem como os tipos de atividade não são rígidos quanto às iluminâncias limites recomendadas, ficando a critério do projetista avançar ou não nos valores das classes/tipos de atividades adjacentes, dependendo das características do local/tarefa.

Para a determinação da iluminância conveniente é recomendado considerar os fatores idade, velocidade e precisão, e refletância do fundo da tarefa, os quais estão descritos na tabela 4. Deve-se analisar cada característica para determinar o seu peso $(-1,0$ ou +1$)$ e somar os três valores encontrados, algebricamente, considerando o sinal. A partir desse resultado pode-se usar a iluminância inferior do grupo, quando o valor total for igual a -2 ou -3; a iluminância superior, quando a soma for +2 ou +3; e a iluminância média, nos outros casos. 
Tabela 4 - Fatores determinantes da iluminância adequada

\begin{tabular}{|l|c|c|c|}
\hline \multirow{2}{*}{$\begin{array}{l}\text { Características da tarefa } \\
\text { e do observador }\end{array}$} & -1 & 0 & +1 \\
\cline { 2 - 4 } & Inferior a 40 anos & 40 a 55 anos & Superior a 55 anos \\
\hline Idade & Sem importância & Importante & Crítica \\
\hline $\begin{array}{l}\text { Velocidade e precisão } \\
\text { da tarefa }\end{array}$ & Superior a 70\% & 30 a 70\% & Inferior a 30\% \\
\hline
\end{tabular}

Fonte - ASSOCIAÇÃO BRASILEIRA DE NORMAS TÉCNICAS (1992, p. 2)

\subsection{Eficiência Energética}

A preocupação para a obtenção de conforto térmico e visual de uma edificação tem se intensificado com maior freqüência nas últimas décadas do século $X X$. E nos últimos anos tem aumentado nos projetos de arquitetura, o interesse quanto ao condicionamento térmico e sistemas de iluminação naturais por razões não só de conforto, mas também de eficiência energética. É importante destacar que importante parcela do consumo total de energia elétrica em um edifício se deve aos equipamentos de climatização - seja para o aquecimento ou para a refrigeração dos ambientes - e à iluminação artificial.

O uso otimizado da ventilação natural, o emprego de materiais de forma adequada e o aproveitamento de luz natural em edificações usadas principalmente durante o dia produzem uma contribuição significativa para a redução do consumo de energia elétrica, além de melhoria do conforto ambiental e bem-estar dos ocupantes. Dessa forma, o montante de energia elétrica necessária para climatização e iluminação em um edifício depende, fundamentalmente, de seu projeto.

O crescimento da utilização dos equipamentos de climatização e dos inovadores sistemas de iluminação artificiais se deve ao avanço das tecnologias que vem ocorrendo desde a segunda metade do século $X X$, avanços necessários, mas que usados de maneira desordenada e muitas vezes desnecessária vêm resultando, conforme termos utilizados por Romero (2000), na separação do casamento entre a arquitetura e o clima. Atualmente os fatos ocorridos vêm sendo mais agravantes: são concebidos edifícios do 
setor terciário com comportamento pior que o do clima. Na década de 1950, Mange já discutia a questão:

O enorme desenvolvimento técnico-científico e industrial possibilitou ao homem moderno a criação de 'invólucros' isolantes com microclima artificial. O 'condicionamento' do ambiente em termos de conforto humano pôde ser realizado. As ciências analisaram os fatores do problema, as técnicas concretizaram a solução. Como, neste caso, os agentes físicos são controlados pelo homem e todo o processo envolve custo (instalação e manutenção-energia) impôs-se, logicamente, a necessidade do conhecimento sempre mais apurado das leis dos fenômenos e das soluções tecnológicas (MANGE, 1956, p. 27).

Em todo esse processo é extremamente importante a função do arquiteto e a sua conscientização. É preciso cuidado na utilização dos sistemas artificiais e a utilização, sempre que possível, dos recursos passivos, como ventilação natural, resfriamento evaporativo e umidificação, massa térmica, e aquecimento solar passivo. Romero (2000) cita como exemplos que utilizaram alguns desses recursos as casas leves e ventiladas da região norte do país, os edifícios com elevada inércia térmica para climas com elevada amplitude térmica, os pátios e as fontes internas dos castelos mouros e as habitações de madeira do hemisfério norte isoladas termicamente.

Essas estratégias de projeto apresentadas são recursos utilizados para resfriamento e/ou aquecimento de edificações, ficando evidente a importância do projeto arquitetônico e da conscientização do arquiteto no processo de conservação de energia. É preciso ter a consciência da possibilidade de utilização dessas estratégias, quando utilizá-las e em quais casos conciliá-las com estratégias de condicionamento artificiais. 


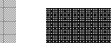




\section{O BLOCO E1: ARQUITETURA, HISTÓRIA E TÉCNICA}

\subsection{A criação da Escola de Engenharia de São Carlos}

Nas décadas de 1940 a 1960 ocorre a propagação do ensino superior no Brasil, principalmente no Estado de São Paulo. O desenvolvimento dos setores industrial e burocrático-administrativo, a expansão urbana e o crescimento populacional ocasionaram uma situação em que a procura por vagas nas universidades era maior que a oferta. Nesse contexto, na década de 1940, enquadra-se o processo de ampliação da USP - Universidade de São Paulo e a sua expansão para o interior do Estado (figura 6).

Segundo Nosella e Buffa (2000) sobre a criação da Escola de Engenharia de São Carlos como uma faculdade pertencente à USP:

A criação dessa escola de nível superior numa cidade do interior paulista com apenas quarenta mil habitantes, no final dos anos 40, foi ato de grande ousadia. Certamente a posição da cidade, no centro geográfico do estado, seu impulso industrial, suas vitoriosas escolas Normal e Profissional contribuíram para a concretização de tão arrojado projeto. Após muitas vicissitudes políticas, essa faculdade foi criada pela Lei Estadual n. 161, de 24/9/1948, e instalada quatro anos depois pela Lei Estadual n. 1968, de 16/12/1952, que definiu sua estrutura administrativa e didática ( NOSELLA; BUFFA, 2000, p. 15). 


\section{Faculdade de Enuenharia par|a São Carlos}

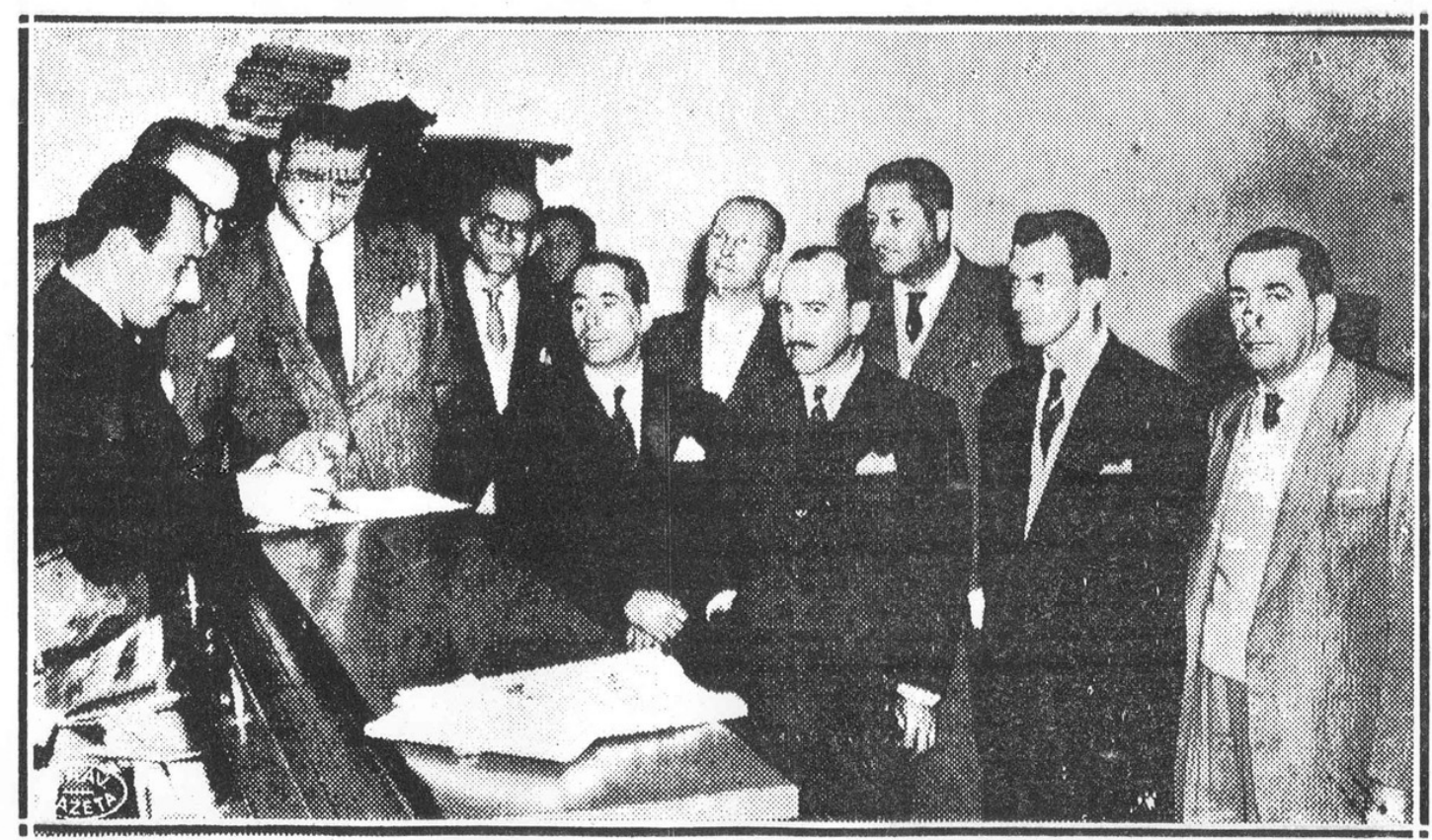

Os visitantes em nossa redaçáo

Após haver estado em visita ao Luiz Augusto de Oliveira, Miguel de autoria do deputado Miguel Pereitor da Universidade de S. Paulo, Petrilli e Vicente Botta, prefelto trilli, cria a Faculdade de Engeprof. Antonio Carlos Cardoso, es- municipal de São Carlos, sr. An- nharia, como dependencia da Uni-

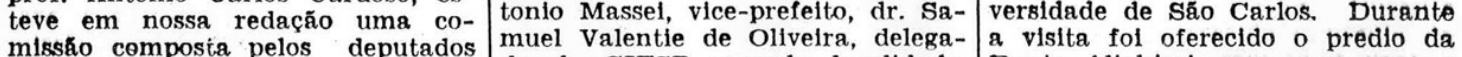
missáo composta pelos deputados do da CIESP naquela localidade, Dante Alighieri, sem onus para o dr. Germano Fehr Junior, sr. Gen- Estado e Municiplo, para a instil de Azevedo, Vitorio Glometti, talaç̃o da Faculdade de Engenhapresidente da Dante Allghterl e ria tendo o prof. Antonio Carlos prof. J. Paulo Spallini, represen- Cardoso declarado que tudo fará tando o Rotary Clube de sấo Car- para que seja a mesma instalada o los. Essa comissão, em sua visita entre em funcionamento em 1953. ao reitor, teve a oportunidade de Para tanto, dentro de alguns dias, focalizar o desejo de verem toma- designará o incorporador da Faculdas todas providencias no sentido dade de Engenharia de São Carlos, de dar execuçáo à lei, cujo projeto, por intermedio do Conselho Universitario.

Figura 6 - Jornal Gazeta de São Paulo (1952) sobre a criação da EESC

Fonte - BLOCO E1: fotos diversas (2005)

Criada em 1948, a EESC foi estabelecida em 1952, oferecendo os cursos de Engenharia Civil e Engenharia Mecânica. A princípio ocupou a Casa d'Itália (figura 7), edifício situado no centro da cidade, hoje conhecido com CDCC - Centro de Divulgação Científica e Cultural da USP. Em 18 de abril de 1953 foi proferida a Aula Inaugural pelo Professor Doutor Lucas Nogueira Garcez. Com a doação da área definitiva da escola pela prefeitura, foi contratado o escritório de São Paulo do arquiteto Hélio de Queiroz Duarte e do engenheiro Ernest Robert de Carvalho Mange para a execução do projeto da 
escola, que deveria ter o porte de um campus. A primeira edificação a ser construída nesse campus foi o Bloco E1 (figura 8).

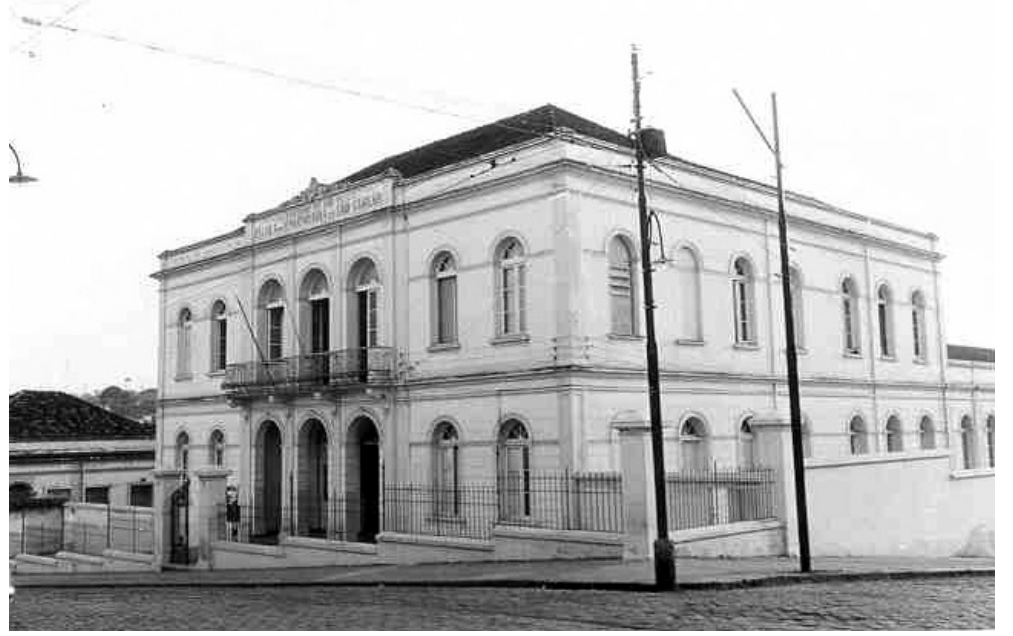

Figura 7 - Casa d'Itália - Primeiro edifício ocupado pela EESC Fonte - BLOCO E1: fotos diversas (2005)

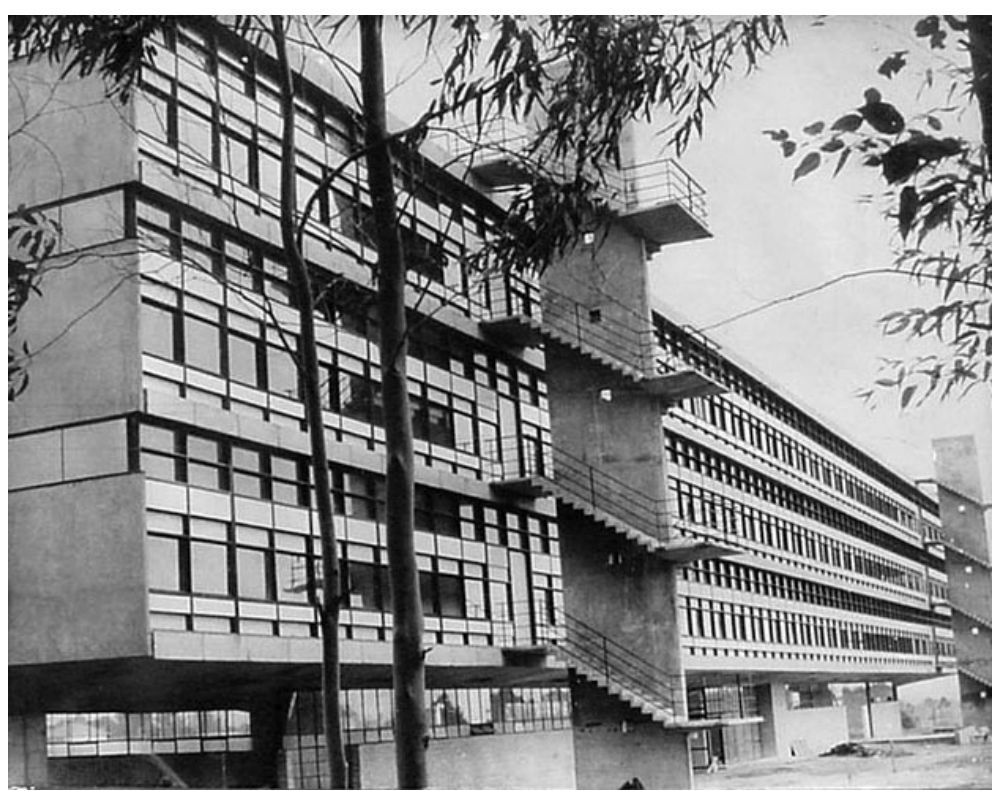

Figura 8 - Bloco E1 - Primeiro edifício a ser construído no campus da EESC Fonte - BLOCO E1: fotos diversas (2005) 


\subsection{O projeto para o campus}

Hélio Duarte e Mange (figura 9) já tinham realizado muitos projetos para o Convênio Escolar e para as escolas do SENAI, o que influenciou o projeto para o campus. O Convênio Escolar, segundo Araújo (2004), foi um ajuste criado entre Governo Estadual e Prefeitura Municipal de São Paulo, no final da década de 1940, com a finalidade de suprir a demanda de escolas. Objetivava o baixo custo da obra, a rapidez na execução, a padronização de elementos e a racionalização da construção, sendo responsável por parte do grande desenvolvimento da arquitetura moderna paulista. Quanto às escolas SENAI, pode-se verificar em seus projetos o uso em larga escala dos princípios da arquitetura moderna. Segundo Segawa (1998), a sociedade Duarte \& Mange inovou na arquitetura de linhas tradicionalistas nas unidades de São Paulo.

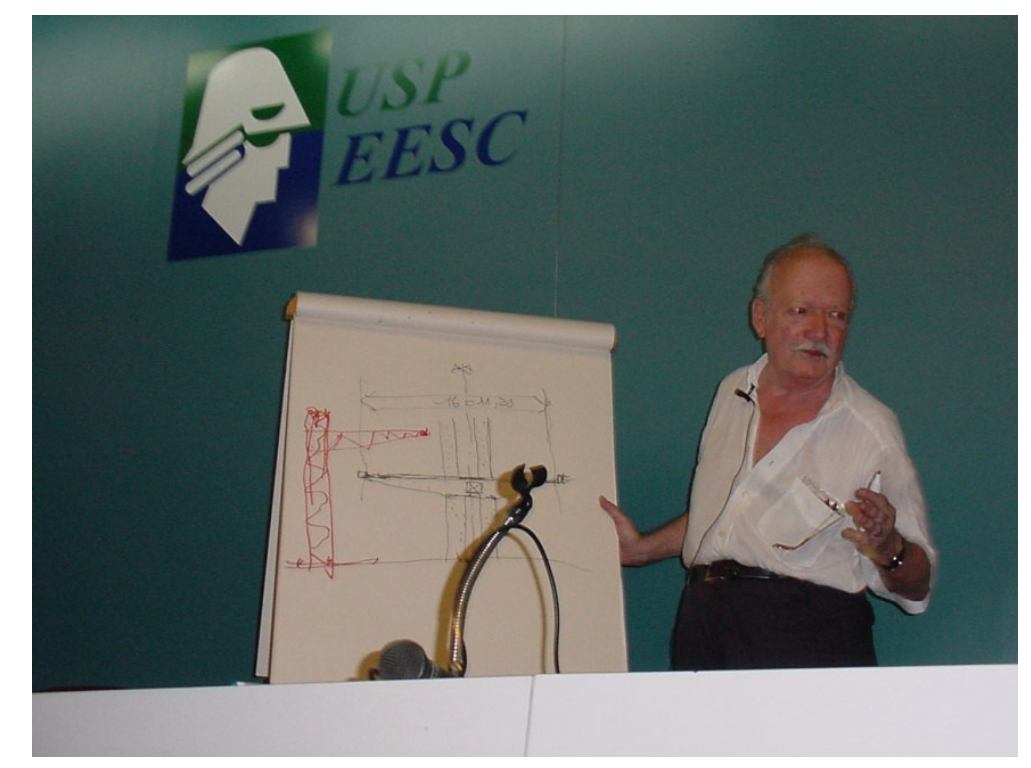

Figura 9 - Mange em palestra apresentada na EESC sobre o Bloco E1 Fonte - BLOCO E1: fotos diversas (2005)

Segundo Araújo (2004), o planejamento para o campus (figura 10) seguiu a mesma linha de raciocínio das experiências com as escolas do Convênio Escolar e do SENAI, a qual partia da divisão do plano em três setores diferentes, com funções estabelecidas pelas definições do zoneamento. Esses três setores são bem definidos pela revista Habitat: 
Foram encaradas as necessidades de Trabalho, Habitação e Recreação, procurando-se obter um todo harmônico, em unidade social e cultural. O programa do setor trabalho exprime as necessidades didáticas e de pesquisas, prevendo a criação de Instituto Tecnológico. No setor habitação foram encarados os problemas de residências de alunos e professores, com seus naturais e imediatos complementos; na recreação as necessidades culturais e esportivas dos habitantes da 'cidade' (DUARTE; MANGE, 1956, p. 45).

O grande uso dos princípios da arquitetura moderna na elaboração do plano é evidente. Esses princípios foram sintetizados por Nosella e Buffa (2000, p. 58) como: "a racionalidade, a funcionalidade, a flexibilidade dos espaços, a integração social e cultural e a utilização da tecnologia moderna (concreto armado, aço, vidro etc.)".

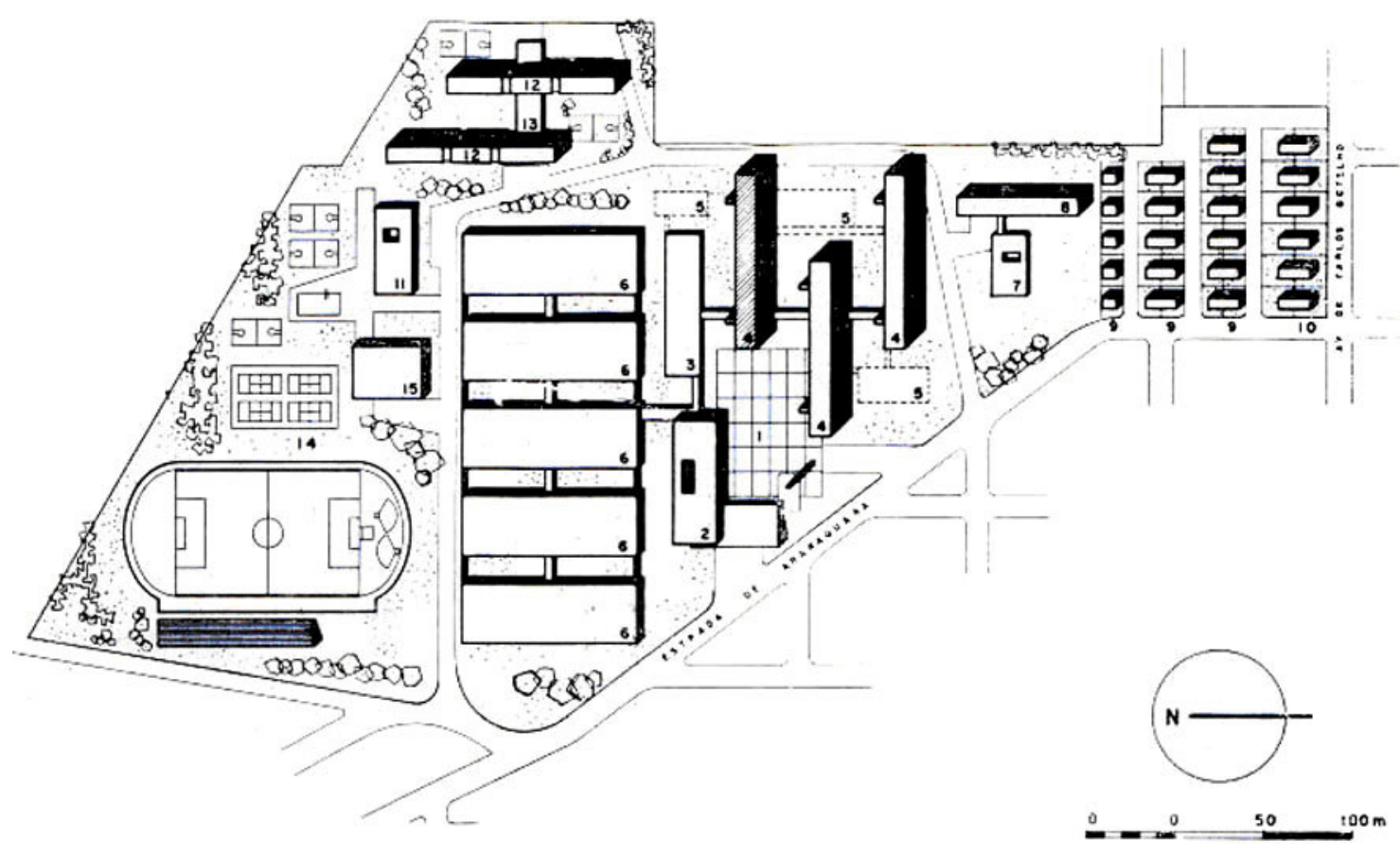

Figura 10 - Plano para o campus da EESC - USP

Fonte - Mange et al. (1959) 
1. Praça Cívica

2. Administração, biblioteca, auditório

3. Anfiteatros (aulas teóricas)

4. Aulas práticas, departamentos, seminários, laboratórios leves

5. Laboratórios especializados

6. Oficinas, laboratórios pesados

7. Centro social

8. Apartamentos

9. Residências -2 dormitórios

10. Residências - 3 dormitórios

Durante a evolução da construção do campus, houve muitas alterações nesse plano inicial, sendo que referente ao projeto das construções somente foi executado o Bloco E1. As figuras 11 a 15 mostram a expansão do campus da EESC situando neste o Bloco E1.

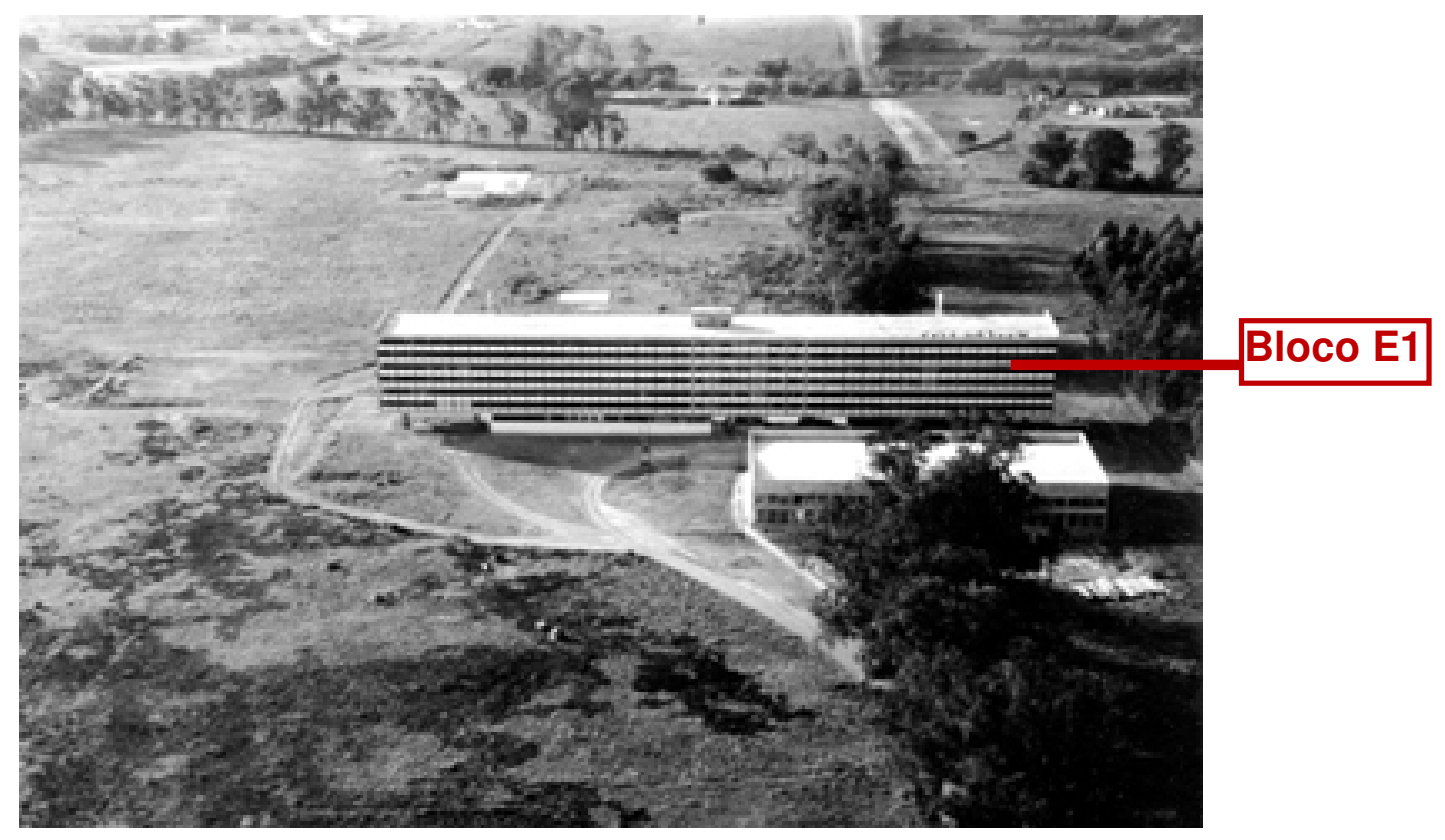

Figura 11 - Campus EESC - USP 1960

Fonte - BLOCO E1: fotos diversas (2005) 


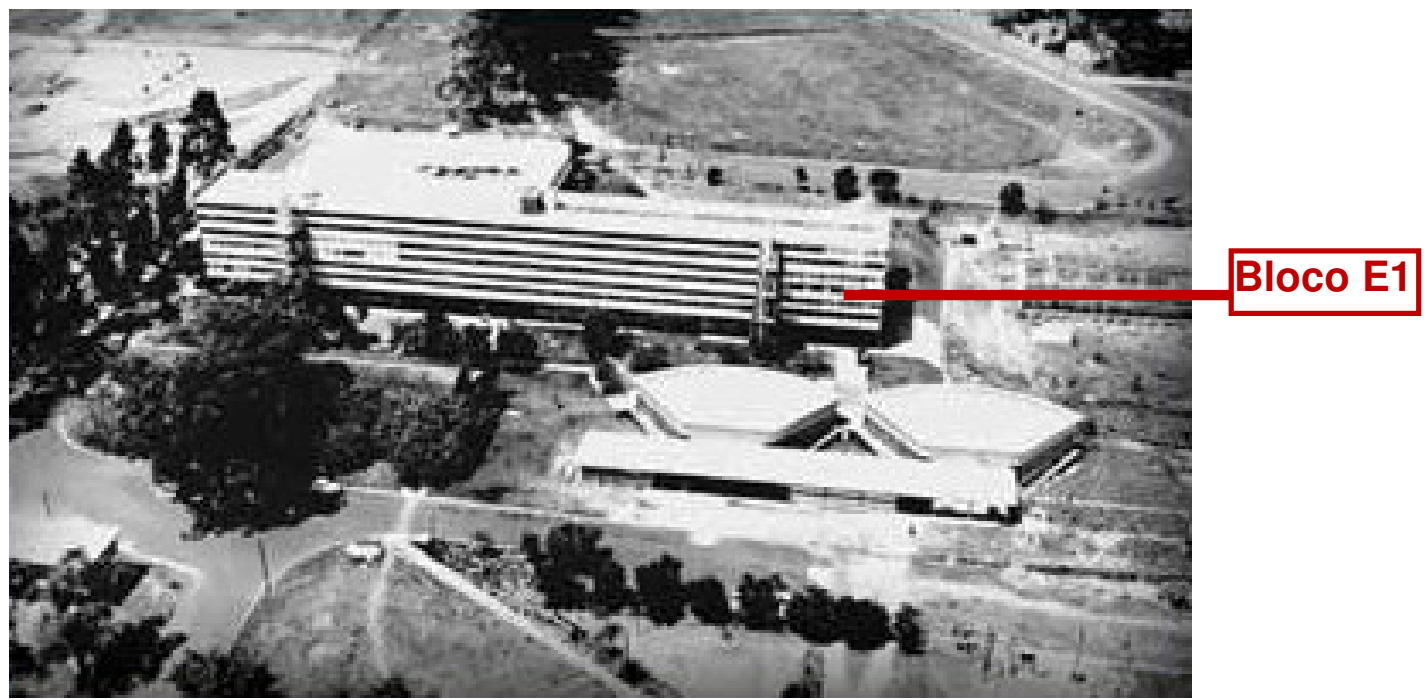

Figura 12 - Campus EESC - USP 1967

Fonte - BLOCO E1: fotos diversas (2005)

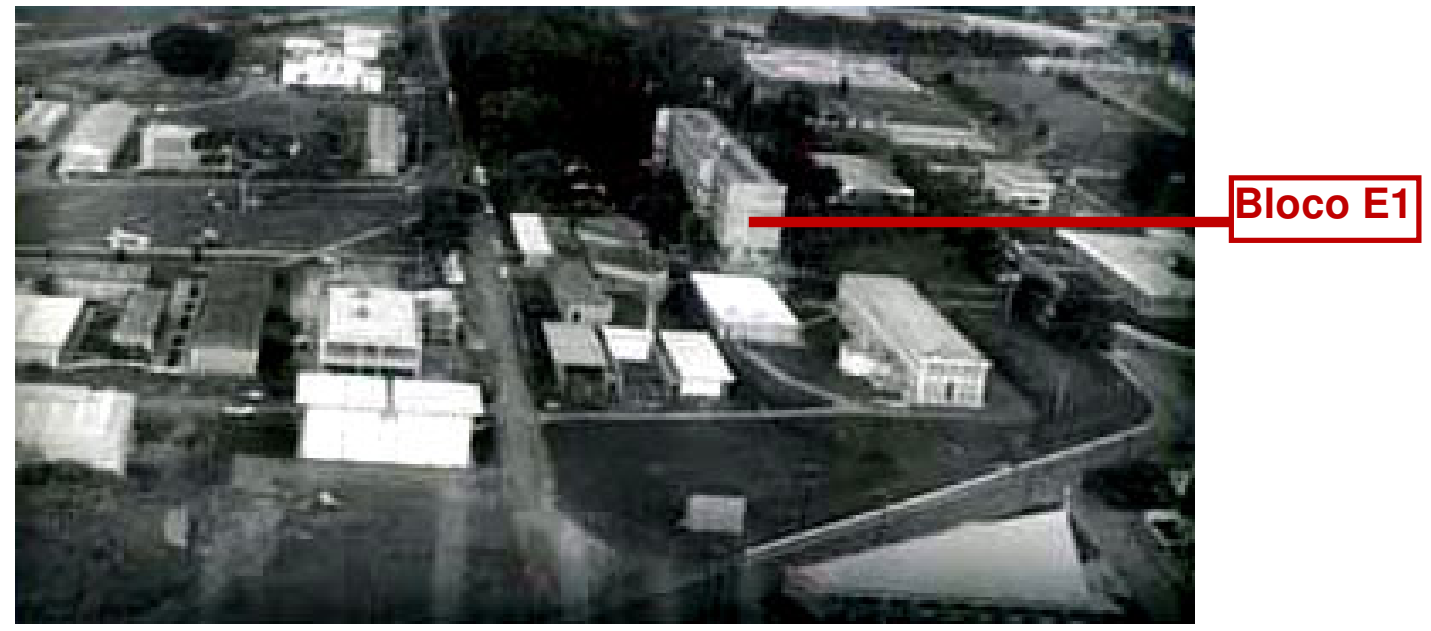

Figura 13 - Campus EESC - USP 1973

Fonte - BLOCO E1: fotos diversas (2005) 


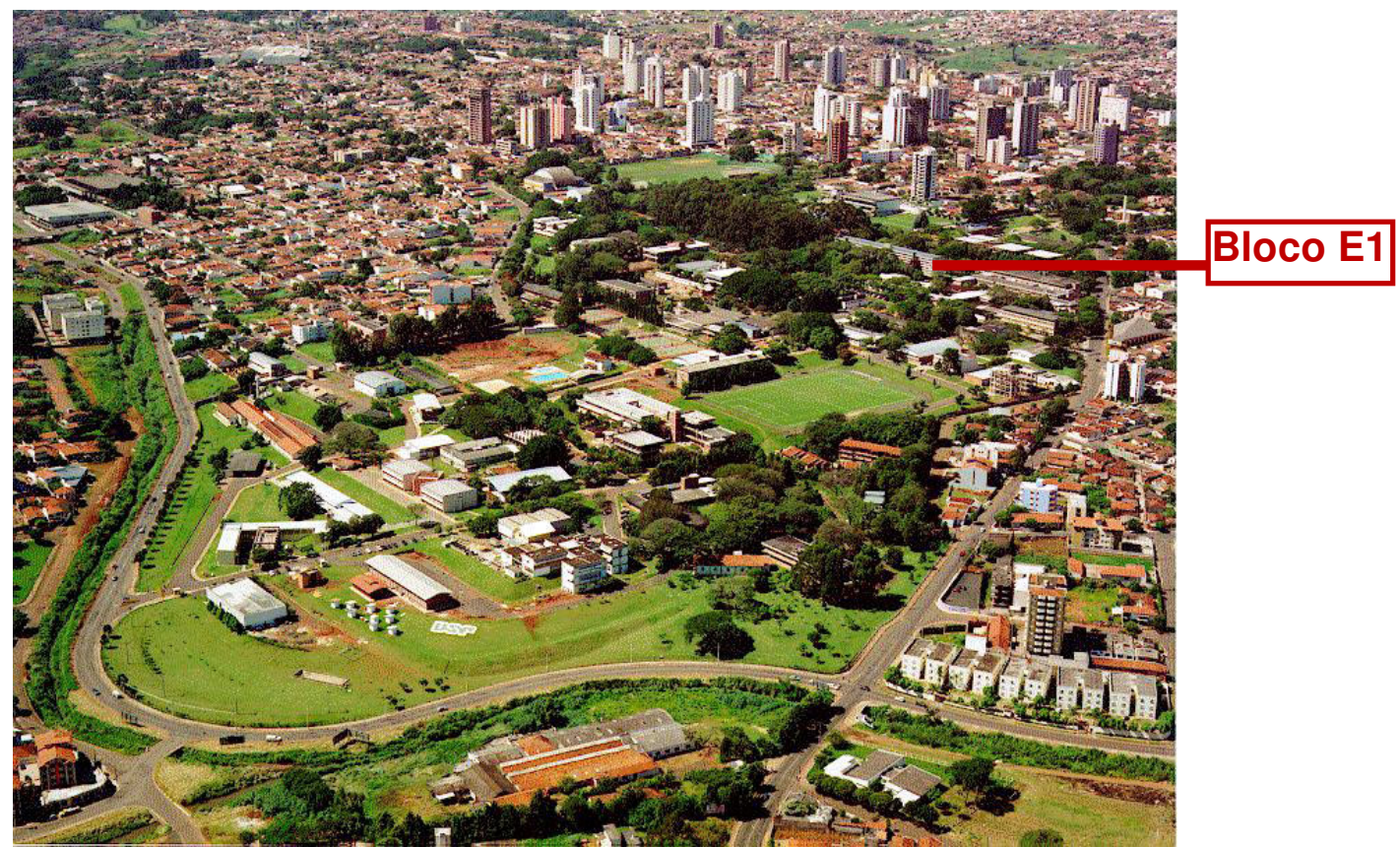

Figura 14 - Campus EESC - USP 1988

Fonte - BLOCO E1: fotos diversas (2005)

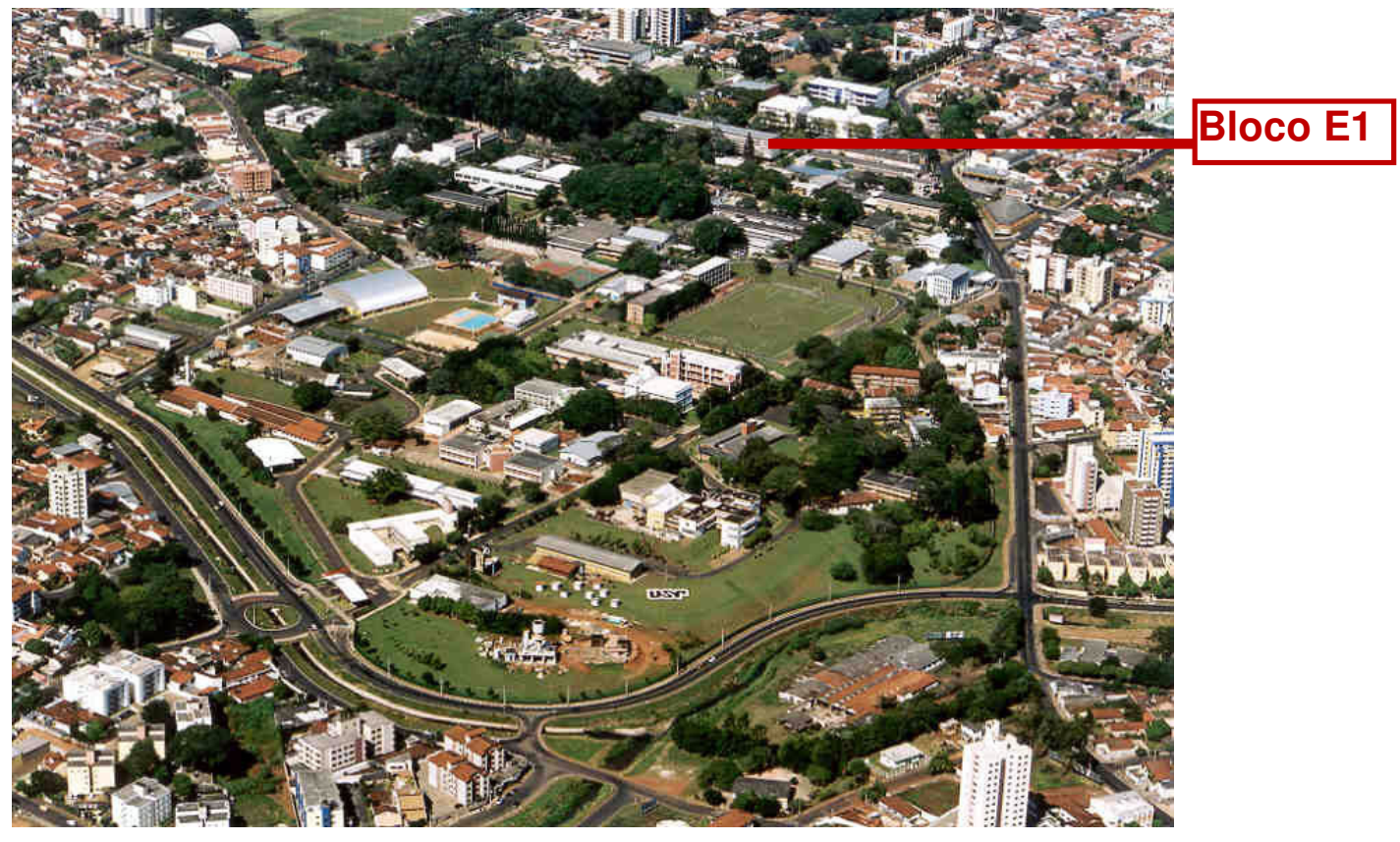

Figura 15 - Campus EESC - USP 2002

Fonte - BLOCO E1: fotos diversas (2005) 


\subsection{O Bloco E1}

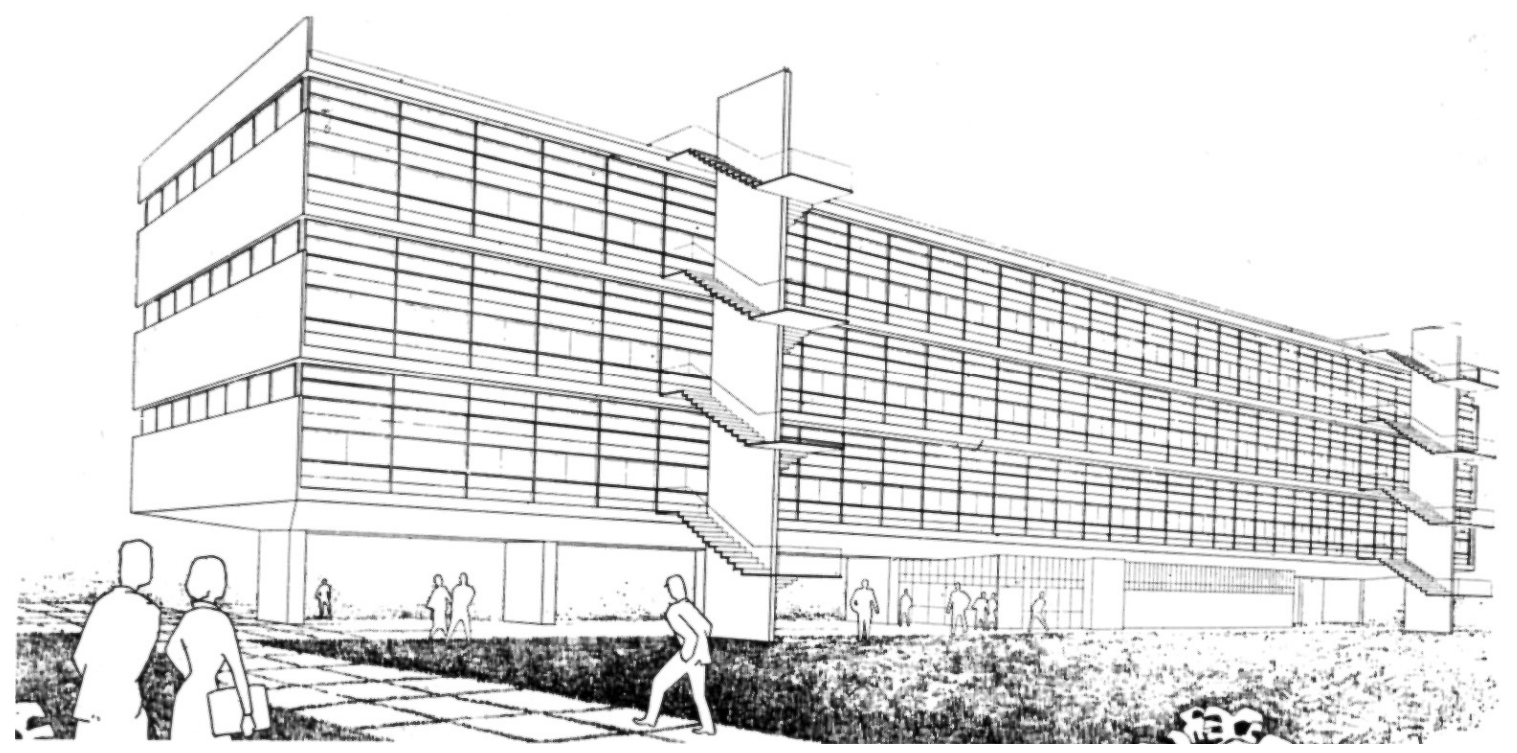

Figura 16 - Perspectiva Bloco E1

Fonte - Duarte e Mange (1956)

Do projeto para o campus somente foi executado um prédio, o Bloco E1 (figuras 16 a 23), o qual foi construído em três anos, com início em 1954, e como integrante do plano teve os princípios da arquitetura moderna como elementos norteadores na elaboração do projeto. Os preceitos de Le Corbusier estavam fortemente presentes nos autores, principalmente em Mange, que foi seu estagiário. Foi essa influência que provavelmente os levou à utilização do concreto aparente, uma das primeiras experiências do tipo no país.

O Bloco E-1 é considerado uma obra marcante, tradução e consolidação da arquitetura moderna, verdadeiro referencial da arquitetura escolar brasileira. Sua construção fugiu às soluções dadas até então pelos projetistas especializados na edificação de prédios escolares, que tradicionalmente imprimiam o estilo neoclássico a esse tipo de instalação (ALTAFIM (Org.), 2004, p. 38). 


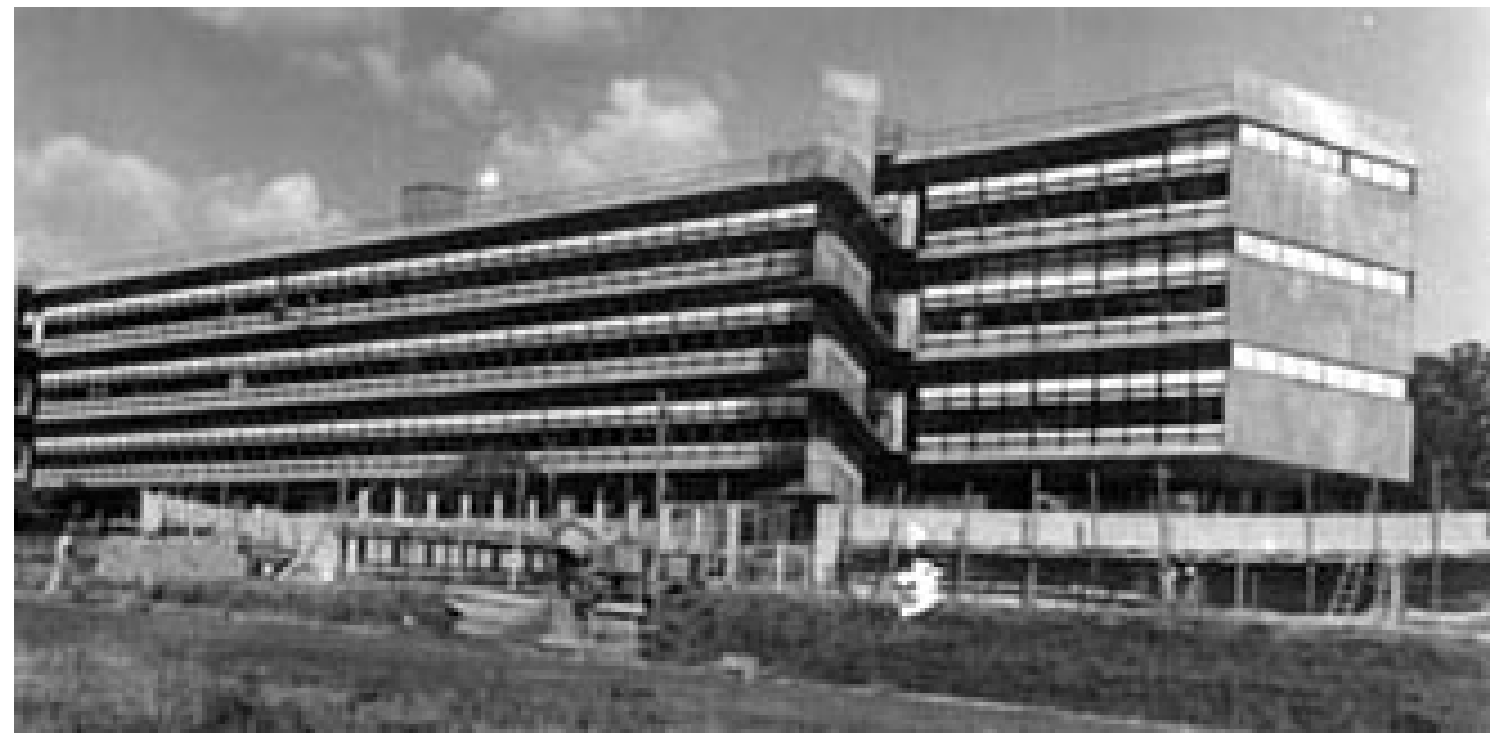

Figura 17 - Bloco E1

Fonte - BLOCO E1: fotos diversas (2005)

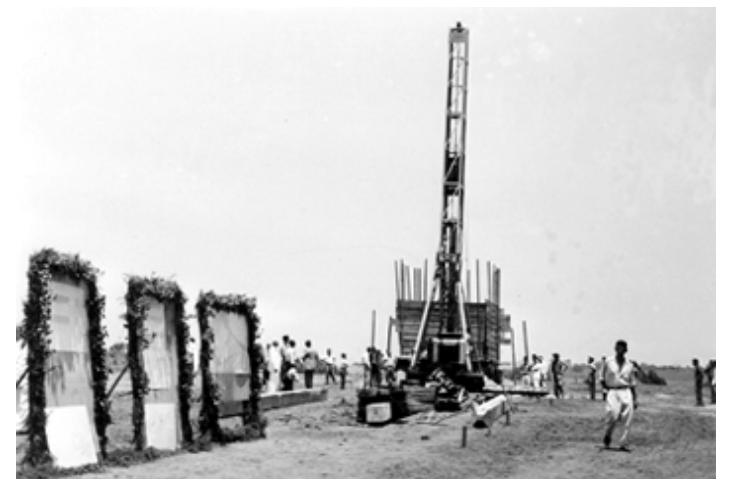

Figura 18 - Estaca Bloco E1

Fonte - BLOCO E1: fotos diversas (2005)

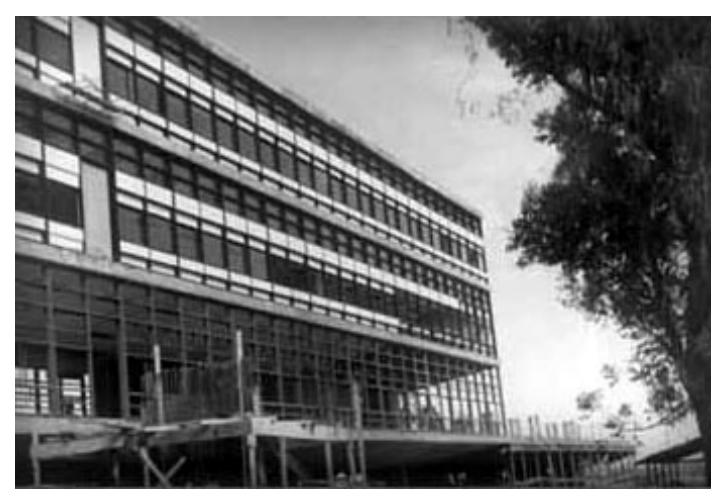

Figura 20 - Construção Bloco E1

Fonte - BLOCO E1: fotos diversas (2005)

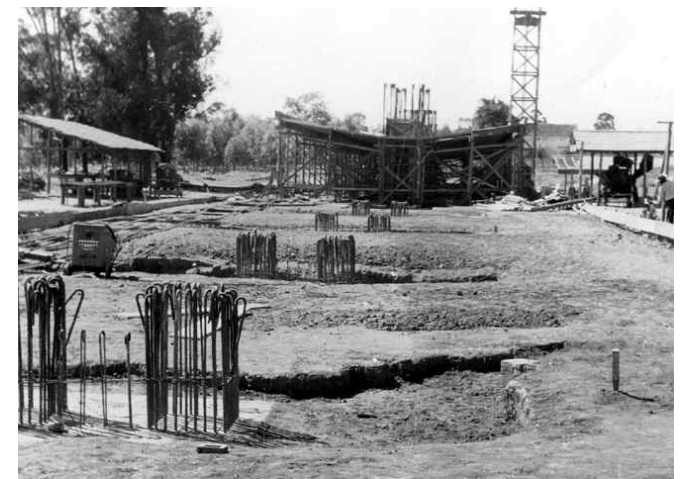

Figura 19 - Construção Bloco E1

Fonte - BLOCO E1: fotos diversas (2005)

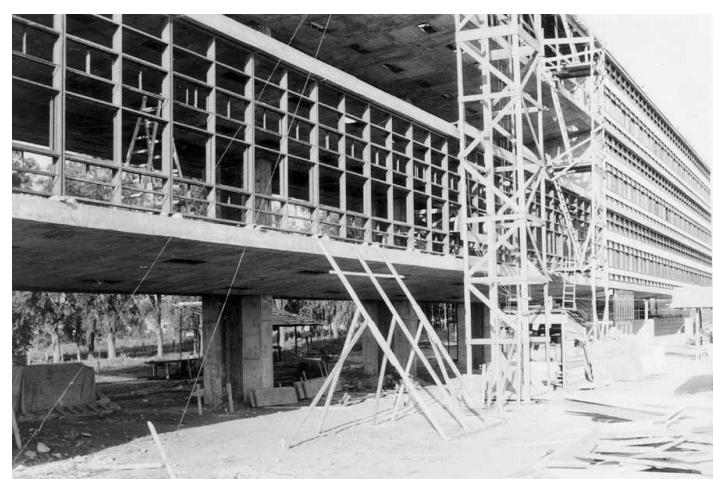

Figura 21 - Construção Bloco E1

Fonte - BLOCO E1: fotos diversas (2005) 


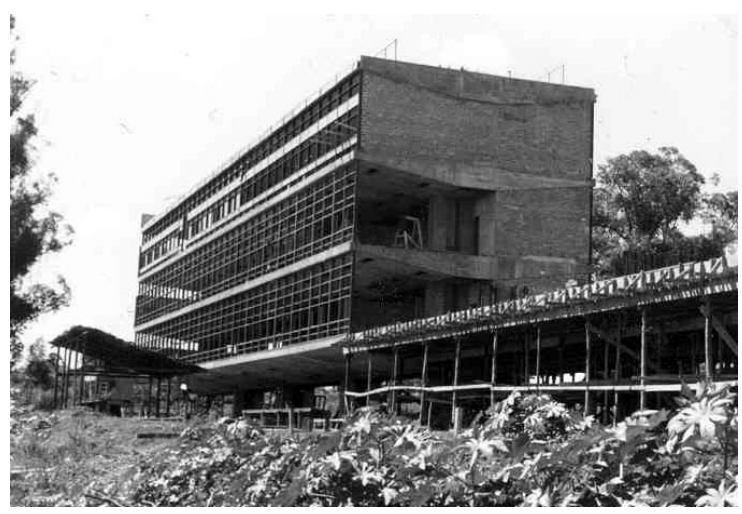

Figura 22 - Construção Bloco E1

Fonte - BLOCO E1: fotos diversas (2005)

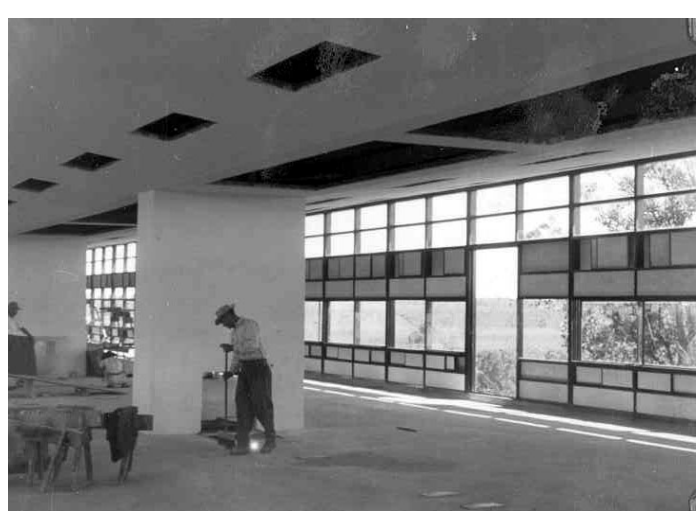

Figura 23 - Construção Bloco E1

Fonte - BLOCO E1: fotos diversas (2005)

Várias características da arquitetura moderna podem ser notadas no prédio: planta livre, pilotis, terraço-jardim, fachada livre e grandes áreas envidraçadas (figuras 24 a 29).

Outra característica importante da arquitetura moderna pode ser observada nesse prédio: o E1 relaciona-se com a natureza por todos os lados, não apresentando uma fachada principal. $O$ térreo, com seus vãos livres permite a livre circulação e a integração com o meio ambiente (NOSELLA; BUFFA, 2000, p. $60)$.

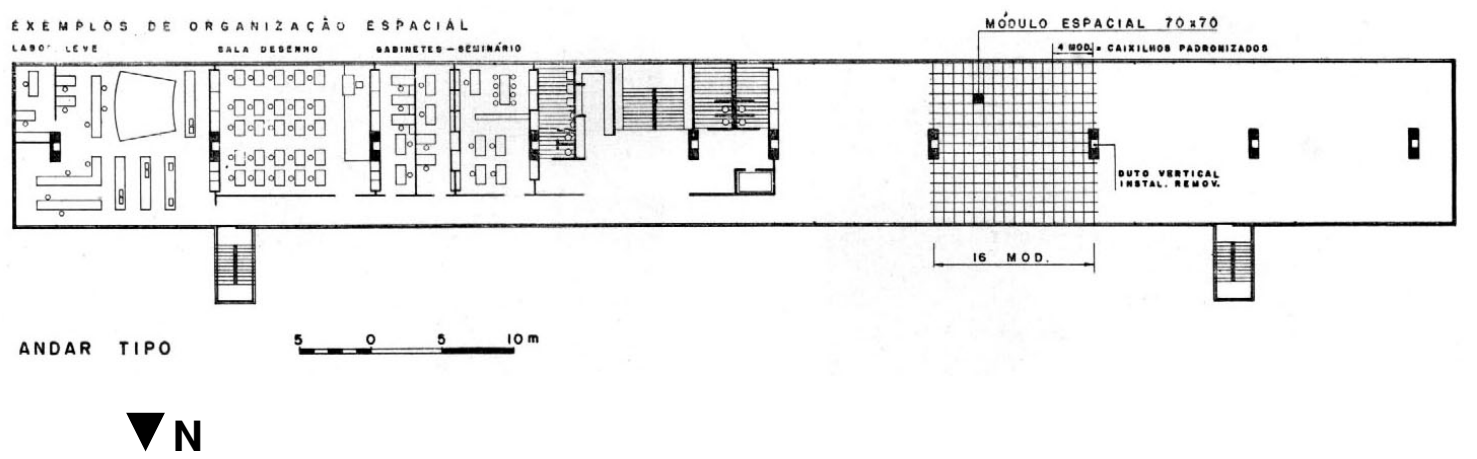

Figura 24 - Planta Tipo Bloco E1

Fonte - Duarte e Mange (1956) 


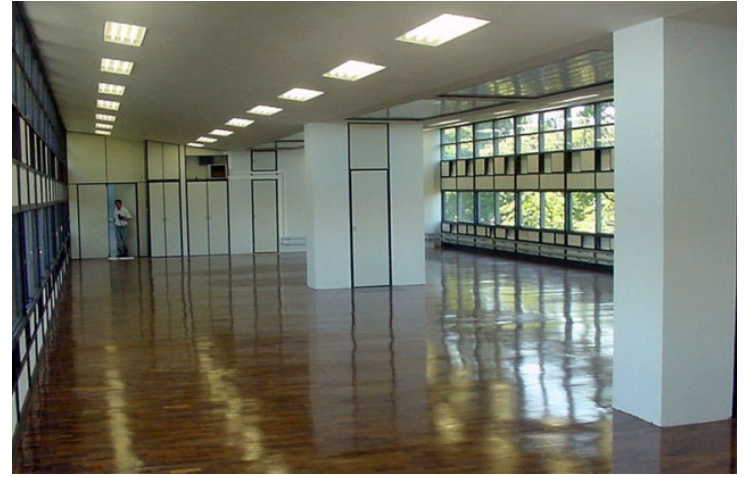

Figura 25 - Interior Bloco E1

Fonte - BLOCO E1: fotos diversas (2005)

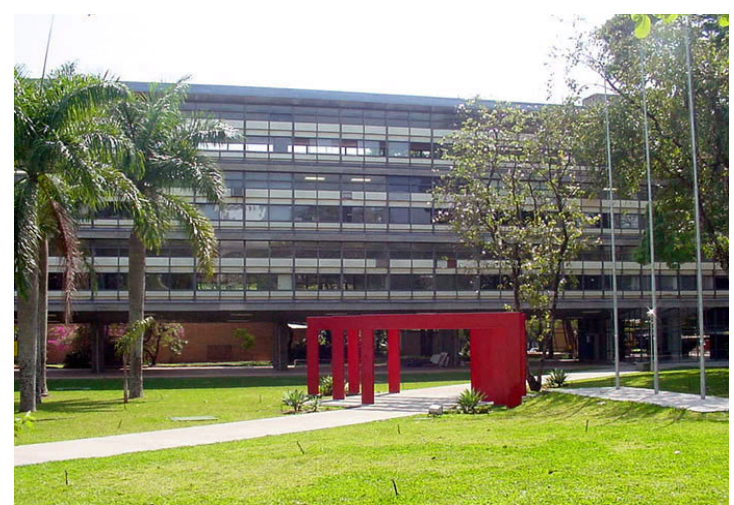

Figura 27 - Fachada Bloco E1

Fonte - BLOCO E1: fotos diversas (2005)

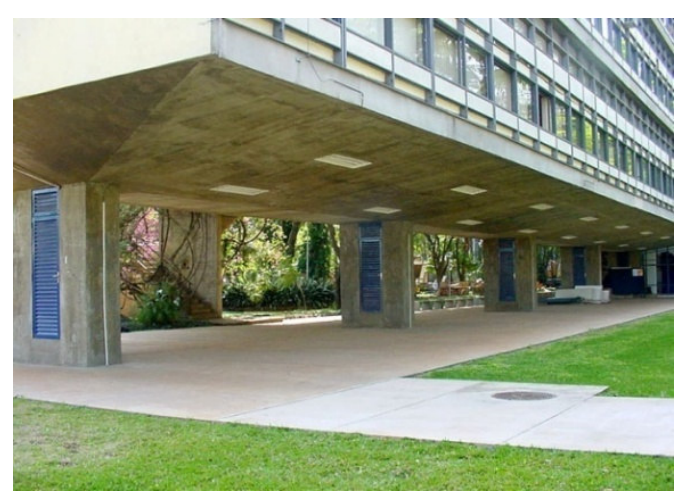

Figura 26 - Vão livre Bloco E1

Fonte - BLOCO E1: fotos diversas (2005)

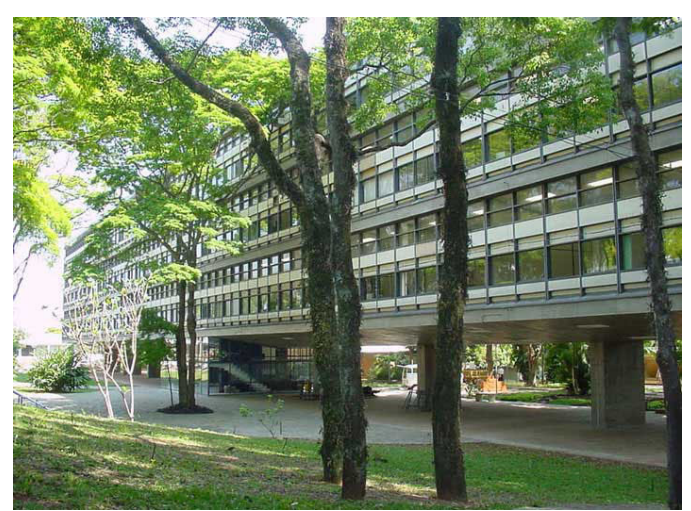

Figura 28 - Fachada Bloco E1

Fonte - BLOCO E1: fotos diversas (2005)

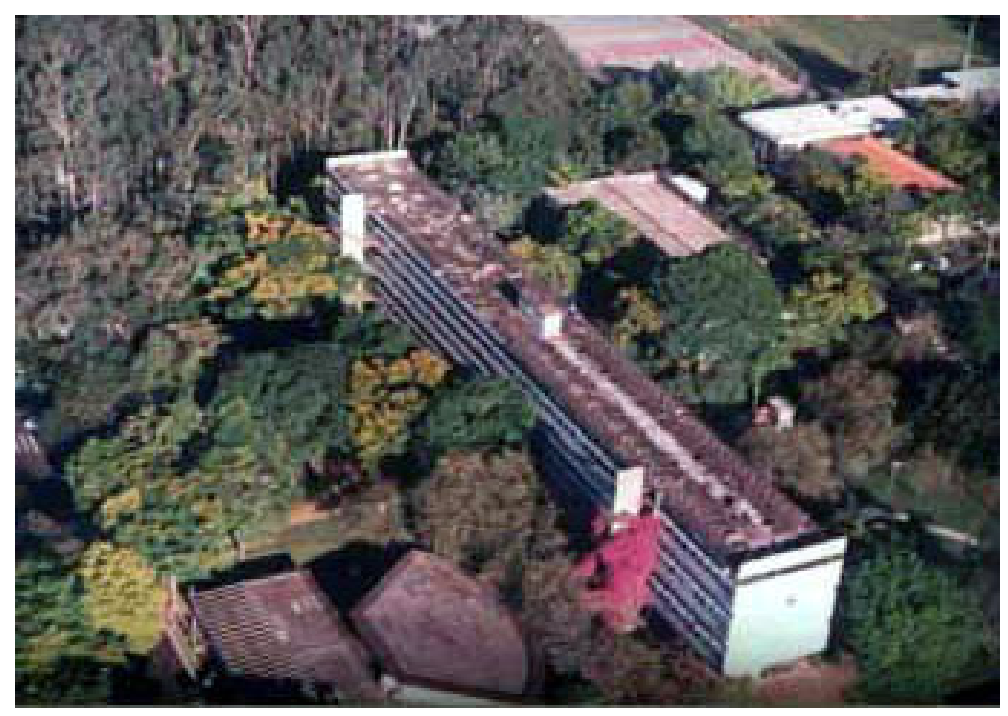

Figura 29 - Vista superior Bloco E1

Fonte - BLOCO E1: fotos diversas (2005) 
A flexibilidade espacial foi um conceito muito presente no projeto do E1. A função prevista inicialmente para o prédio era um bloco de salas de aula, laboratórios, bibliotecas e gabinetes de professores, e conforme fossem ficando prontos outros prédios, as funções poderiam ir se alterando. A modulação e a tipificação (figuras 30 e 31) necessária para a obtenção da flexibilidade estão presentes na estrutura, na vedação interna e externa, e até nas instalações elétricas e hidráulicas. Todas as instalações elétricas e hidráulicas foram embutidas nas colunas e lajes criando sistemas de dutos verticais e horizontais. Através de aberturas podem ser feitas manutenções e alterações nessas canalizações de acordo com a ocupação pretendida (figuras 32 e 33).

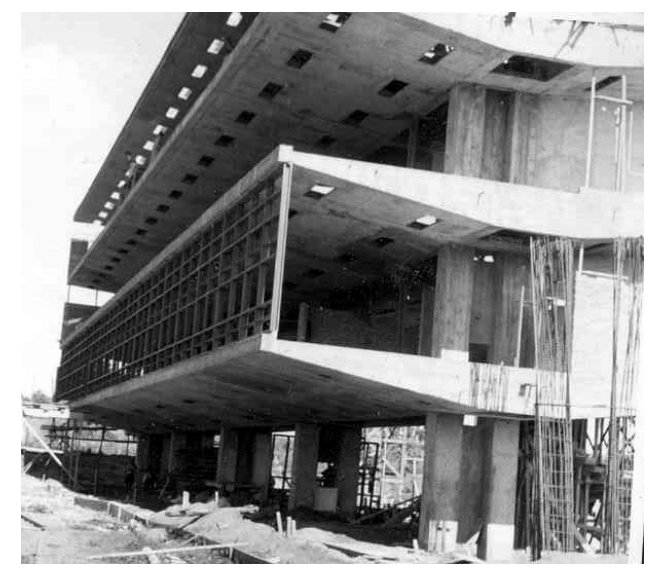

Figura 30 - Construção Bloco E1

Fonte - BLOCO E1: fotos diversas (2005)

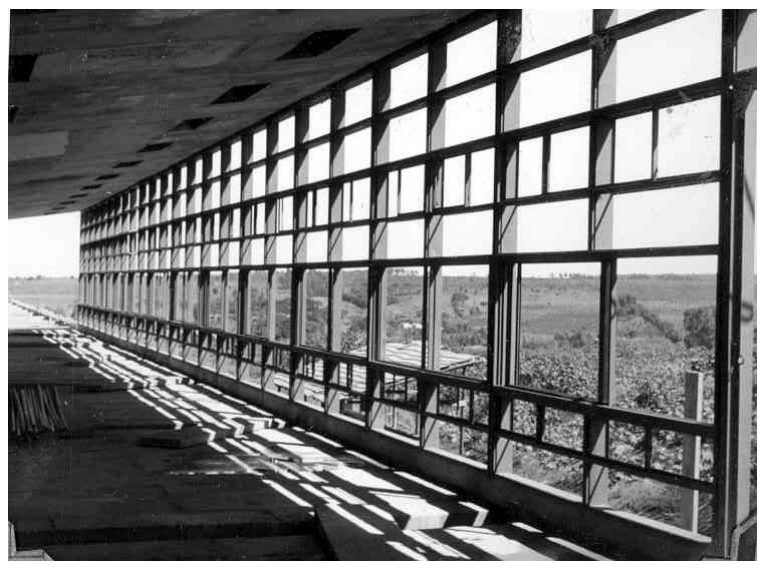

Figura 31 - Construção Bloco E1 Fonte - BLOCO E1: fotos diversas (2005)

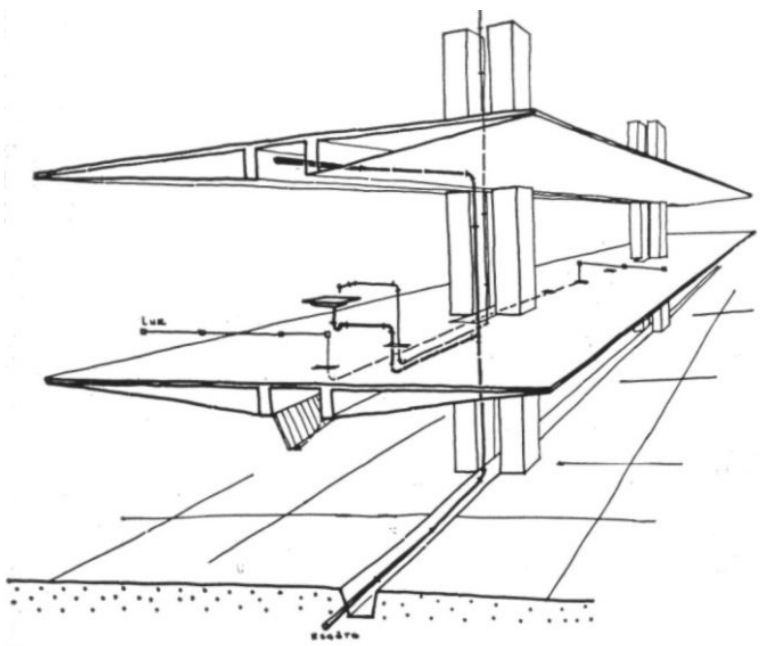

Figura 32 - Esquema das instalações

Fonte - Duarte e Mange (1956)

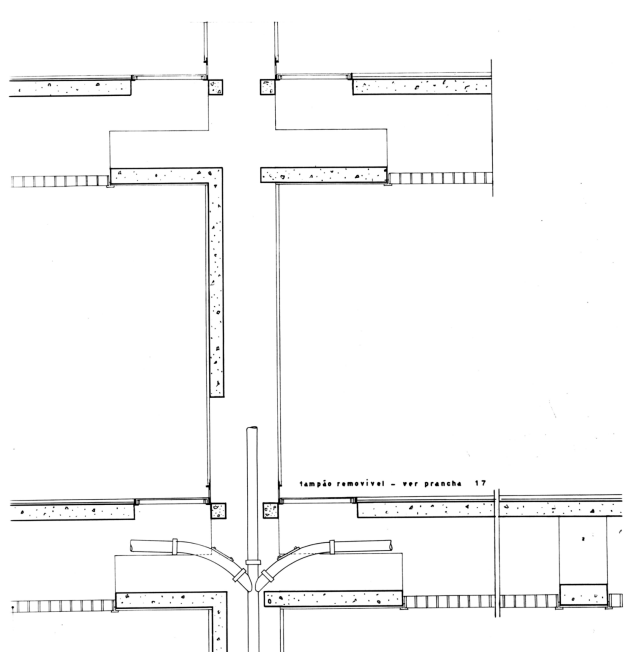

Figura 33 - Detalhe - canalizações Fonte - Duarte e Mange [195-] 
Foi adotado processo construtivo avançado com racionalização e industrialização dos elementos. Segundo a revista Duarte e Mange (1956, p. 45) previa-se a "pré-fabricação dos elementos tipificados da estrutura resistente e da vedação. A concepção permitiu a execução completa da obra sem 0 recurso normal de andaimes".

A modulação também foi uma característica muito importante, havia uma modulação integral, em que todos os elementos seguiam o módulo de $70 \mathrm{~cm}$, medindo em toda sua extensão 144 por 16 módulos. Esse edifício de 4 pavimentos, com térreo parcialmente vazado, 3 andares tipo e cobertura em terraço, assim como é descrito por Duarte e Mange (1956, p. 45), possui estrutura em "árvore", com colunas a cada 16 módulos e balanços de 4,55 m (figuras 34 a 38).

Nós nos propusemos fazer um edifício experimental, com concreto aparente, usando a coordenação modular, com excelentes soluções de conforto, coisas como ventilação diferencial e otimização da iluminação, etc.. As soluções para águas pluviais eram todas inéditas, nunca ninguém tinha feito daquele jeito, tudo acessível pelos andares. Tudo isso para representar a Escola de Engenharia, que ali se instalaria um pólo de desenvolvimento de tecnologia para as construções. Ernest Robert de Carvalho Mange, 2001 (ARAÚJO, 2004, p. 98).

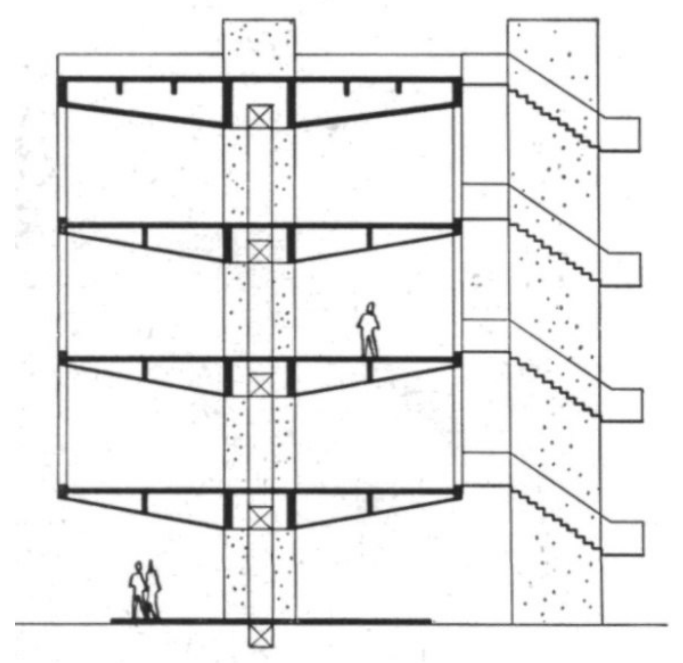

Figura 34 - Corte Bloco E1

Fonte - Duarte e Mange [195-]

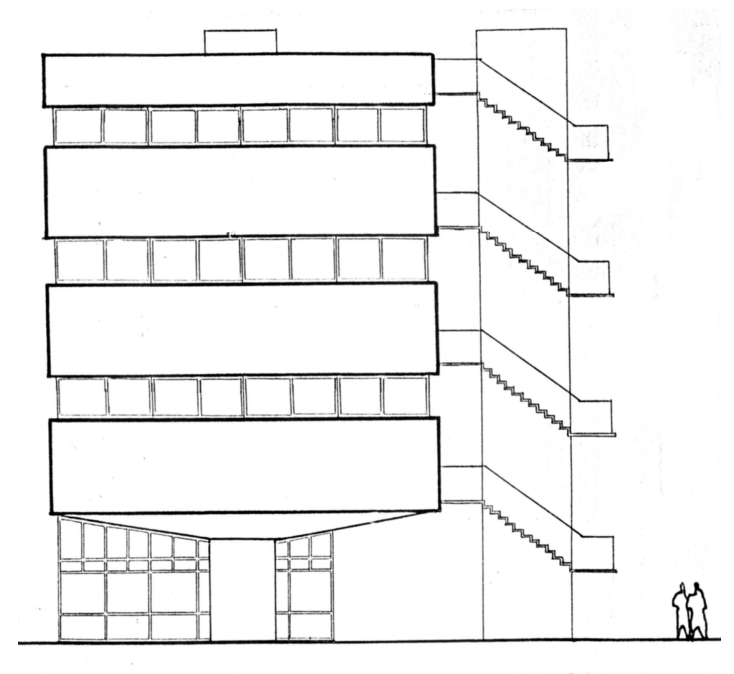

Figura 35 - Elevação Leste Bloco E1

Fonte - Duarte e Mange [195-] 


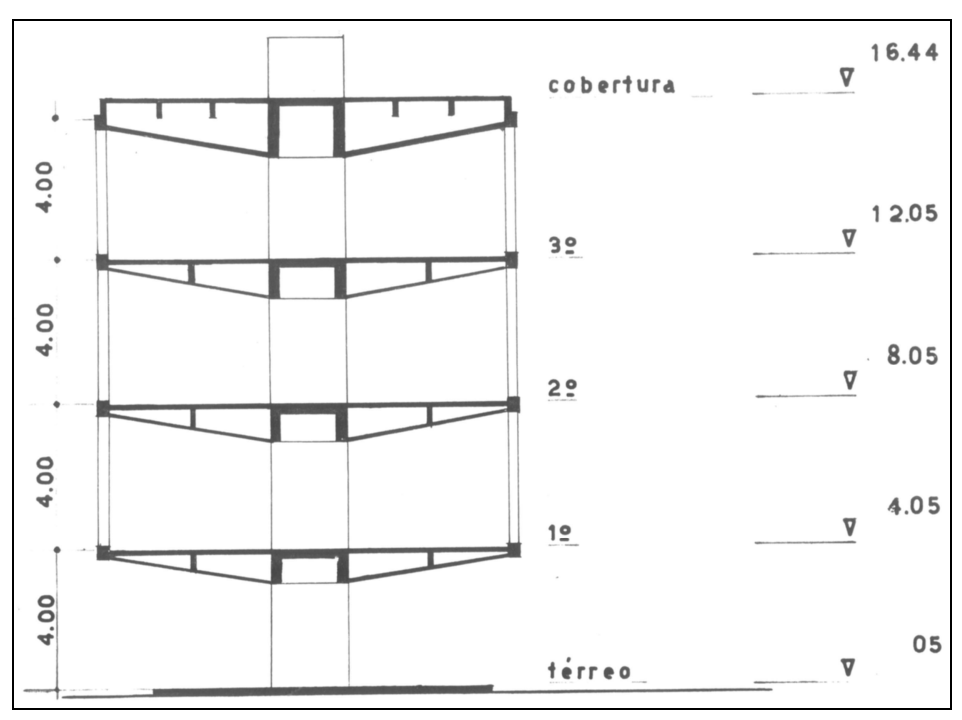

Figura 36 - Corte Bloco E1

Fonte - Duarte e Mange [195-]

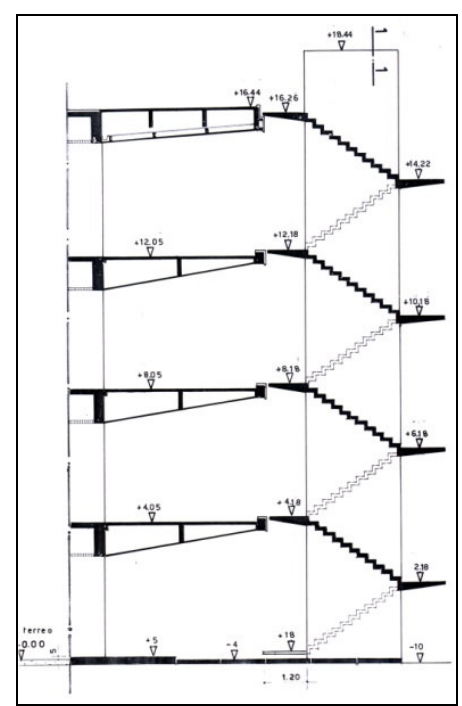

Figura 37 - Corte Bloco E1

Fonte - Duarte e Mange [195-]

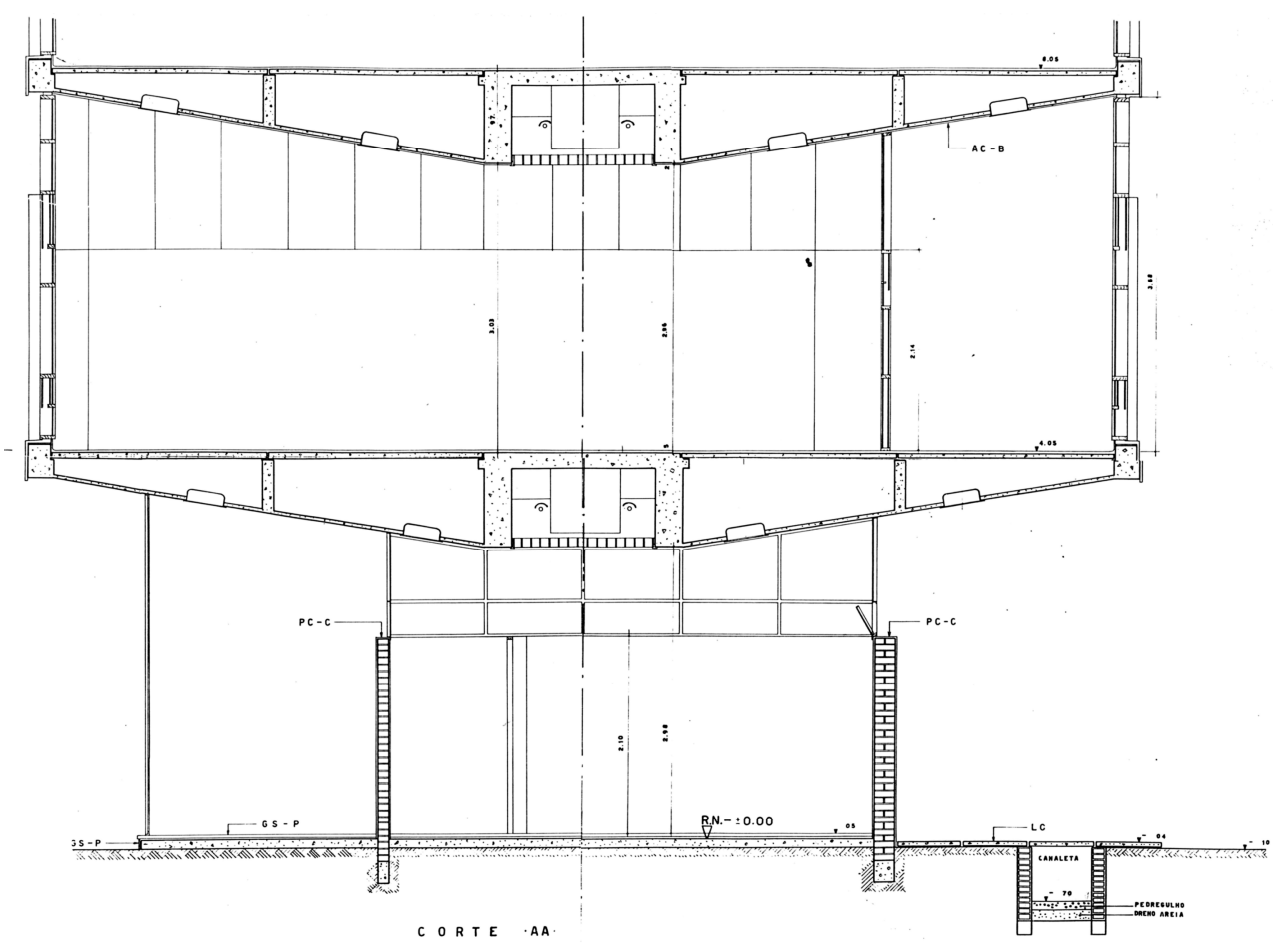

Figura 38 - Corte Bloco E1

Fonte - Duarte e Mange [195-]

As figuras 39 a 42 mostram a atual distribuição e ocupação do Bloco E1. Deve-se ressaltar que o Bloco E1 possui uma importância histórica muito grande, tanto para a arquitetura como para a Escola de Engenharia de São Carlos. O destaque da edificação é comprovado com a sua grande utilização até os dias atuais. 


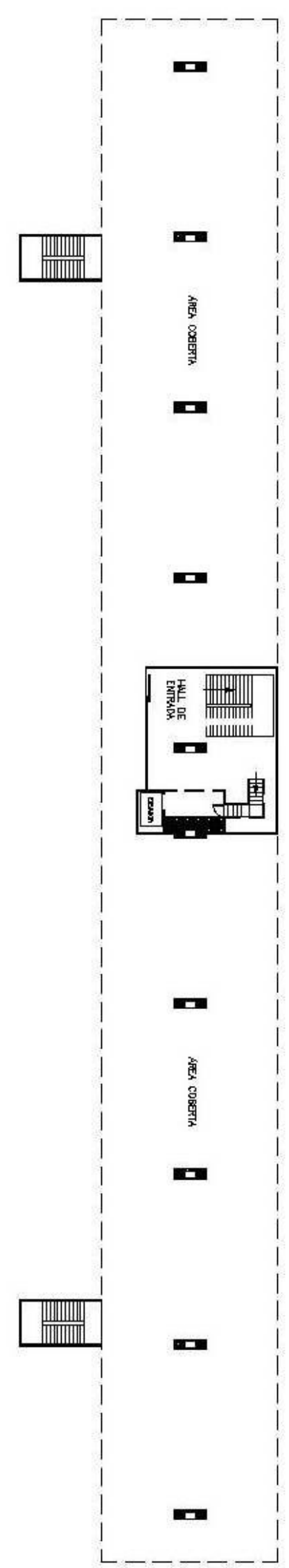

Figura 39 - Planta Térreo - Bloco E1

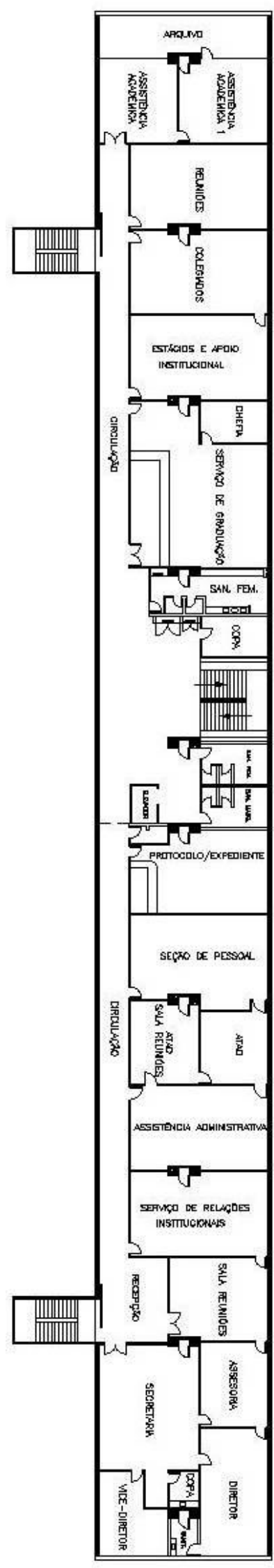

Figura 40 - Planta $1^{\circ}$ Pavimento - Bloco E1 


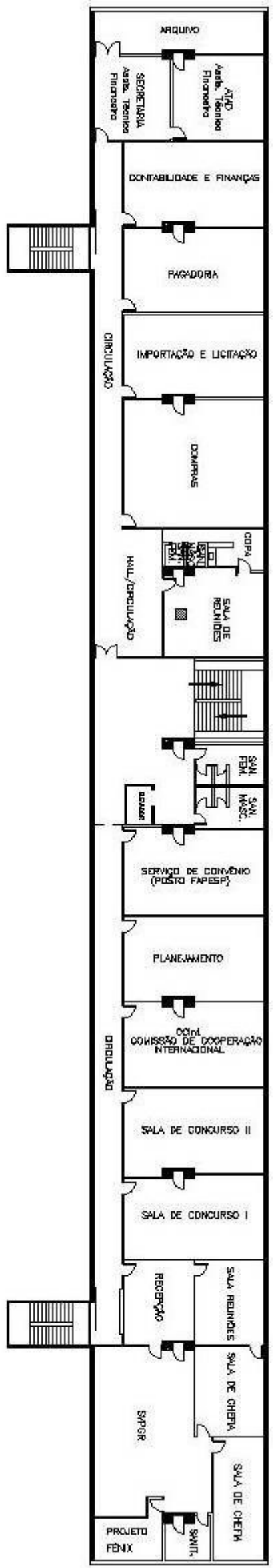

Figura 41 - Planta $2^{\circ}$ Pavimento - Bloco E1

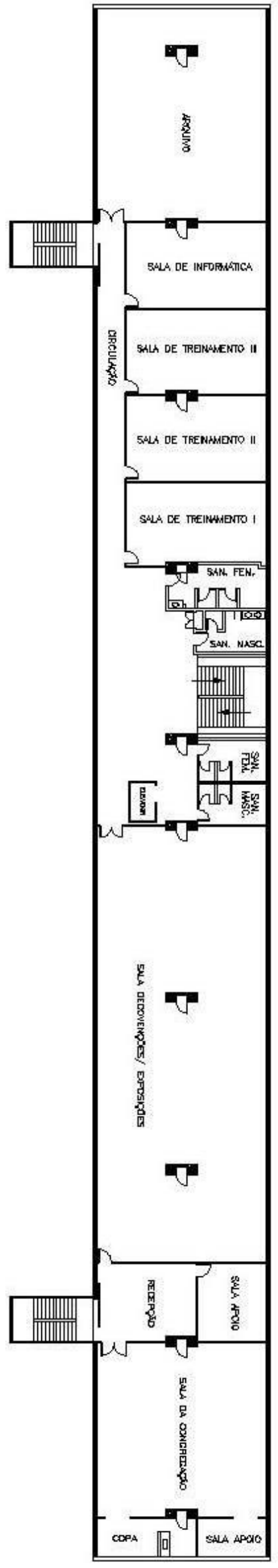

Figura 42 - Planta $3^{\circ}$ Pavimento - Bloco E1 


\subsection{A preocupação com o conforto ambiental}

Segundo Mange (1956, p. 76) a respeito do Bloco E1:

Seus problemas térmicos e acústicos foram seriamente encarados. A iluminação natural e a aeração encontram resposta adequada dentro da expressão plástica do cerramento exterior. Garantidas e expressas as necessidades psicológicas da organização espacial, conseguiu-se evitar ofuscamento excessivo obtendo-se aclaramento uniforme... Por outro lado a consideração integral da 'questão insolação' permitiu a eliminação do sol direto nas superfícies de trabalho (orientação Sul para as salas). Considerando ainda a aplicação dos princípios de ventilação diferencial pode-se prever que resultará aceitável ambiente térmico. Deve-se acrescentar que a massa do edifício e os princípios de industrialização intensiva adotados colocavam em termos bastante delicados os problemas funcionais e estruturais, e, sobretudo, aqueles de sua expressão estética.

O esquema apresentado na figura 43 foi desenvolvido por Mange para demonstrar de forma geral suas estratégias de projeto para ventilação e iluminação naturais das edificações, descreve claramente suas idéias para o Bloco E1. Ele define faixas de áreas transparentes em diversas alturas para obter uma iluminação uniforme no ambiente. Uma dessas faixas torna possível a comunicação do homem com o meio externo, por estar na altura de sua visão, e assim proporcionar maior agradabilidade ao ambiente. Nesse esquema demonstra duas faixas de ventilação permanente, uma baixa e a outra alta, promovendo a circulação do ar, já que $o$ ar frio entra pela abertura inferior e 0 quente sai pela abertura superior. Segundo Mange (1956, p. 77) essa solução "permite dosar adequadamente a aeração, iluminação e insolação, trazendo boas possibilidades plásticas". A descrição do Bloco E1 exemplifica muito bem essas estratégias, claro que com as naturais e necessárias adaptações, como relata Mange (1956). 


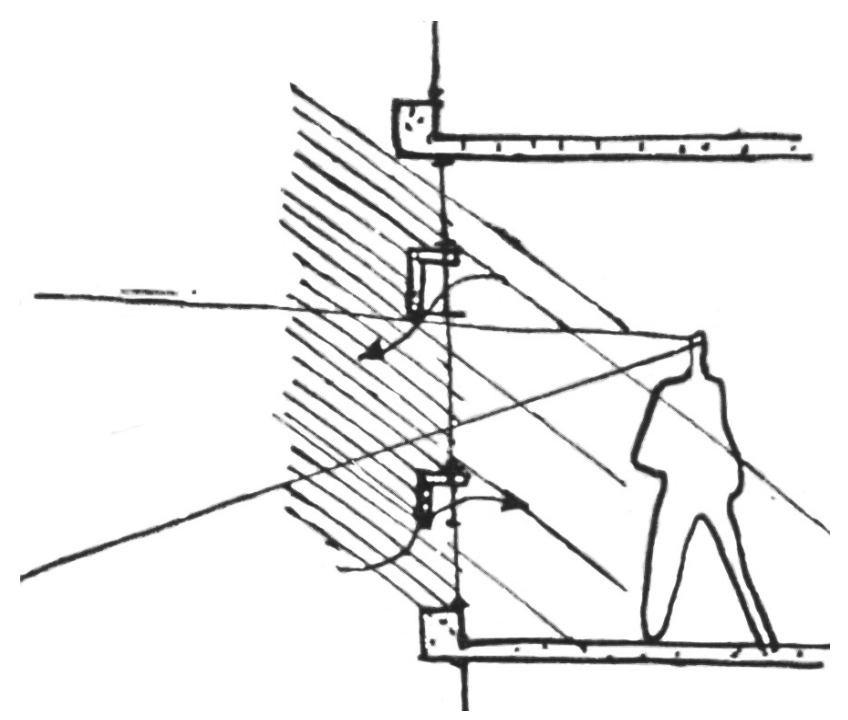

Figura 43 - Esquema de iluminação e ventilação naturais desenvolvido por Mange Fonte - MANGE (1956)

As estratégias utilizadas para a obtenção de conforto térmico e visual nos prédios projetados são bem definidas por Mange (1956):

O principal aspecto da renovação de ar é sua conseqüência no problema térmico. O conforto térmico é função da temperatura, umidade e velocidade do ar. A aeração deve, portanto, ser encarada sob esse ponto de vista e solucionada conjuntamente com os outros fatores que vão, direta e indiretamente, influir na questão térmica.

Teoricamente pode-se afirmar que as trocas de ar entre interior e exterior realizam-se por diferença de pressão. Em conseqüência, são funções dos deslocamentos externos (ventos) e temperaturas exterior e interior. A forma e disposição dos vazios são as outras variáveis da equação. (MANGE, 1956, p. 30)

[...] A iluminação natural no interior do espaço organizado será função de suas ligações (forma, dimensões, posição relativa, etc.) com o exterior e de suas características físicas. Entendese por 'ligações', naturalmente, as partes de sistema material que são permeáveis ao agente radiações solares visíveis. A 
organização dos 'vazios óticos' condiciona a iluminação natural interna em função das condições exteriores.

A fonte de iluminação natural - o sol - dados os fenômenos astronômicos e meteorológicos, é extremamente variável e cumpre fixar um ponto de referência, isto é, tomar condições médias exteriores, para poder analisar as condições interiores trazidas pelo abrigo. Esse critério permite estabelecer uma teoria capaz de orientar convenientemente a utilização da luz natural. Dentro dessa teoria considera-se apenas a luz oriunda da abóbada (radiações solares difundidas e refletidas), desprezando-se as radiações diretas.

Fixada essa premissa o problema da iluminação natural reduzse naturalmente aos termos qualidade e quantidade: distribuição do aclaramento e valor relativo às condições exteriores padrão.

O problema da distribuição é de grande importância para a boa utilização do abrigo. Com a teoria e prática da iluminação natural, pode-se, através da dosagem dos 'vazios', obter distribuição adequada do fluxo luminoso, evitando ofuscamento e zonas de obscuridade. O conforto resultante é de inegável valor humano (MANGE, 1956, p. 33 e 34)

Esses conceitos discutidos por Mange foram aplicados no projeto do Bloco E1, o qual possui orientação norte-sul, com os corredores voltados para o norte e as áreas de trabalho para o sul, evitando-se dessa forma a incidência direta do sol. Na fachada norte, assim como na sul, há em toda sua extensão esquadrias padronizadas, feitas de aço e preenchidas por vidros e placas de eternit. Essas placas opacas foram tratadas como brises incorporados no próprio prédio, não sendo um elemento que se projeta externamente a suas fachadas (figuras 44 a 47). As esquadrias foram consideradas no conjunto da fachada e divididas em faixas horizontais opacas e transparentes, dessa forma pôde promover o controle da incidência solar nas fachadas, principalmente na 
norte. As áreas opacas foram projetadas de modo que pudessem ser abertas quando necessário.

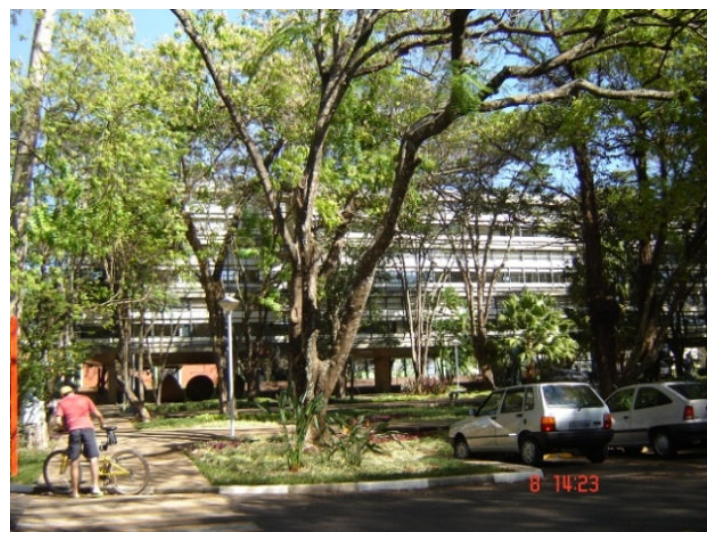

Figura 44 - Fachada norte do Bloco E1

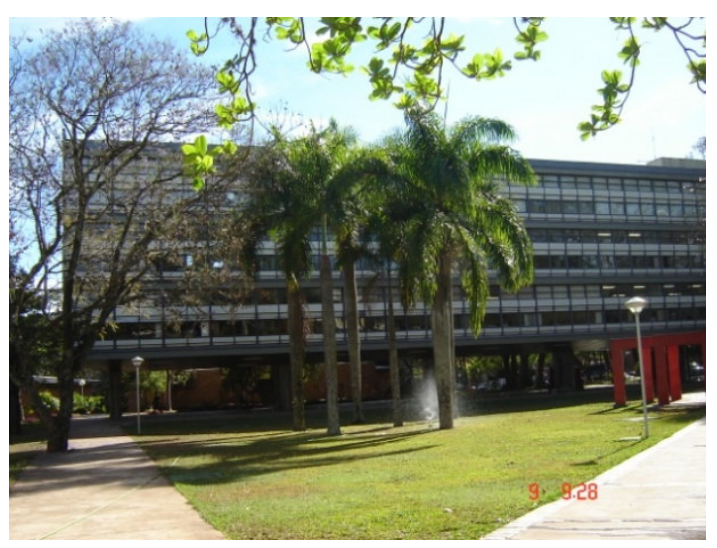

Figura 46 - Fachada sul do Bloco E1

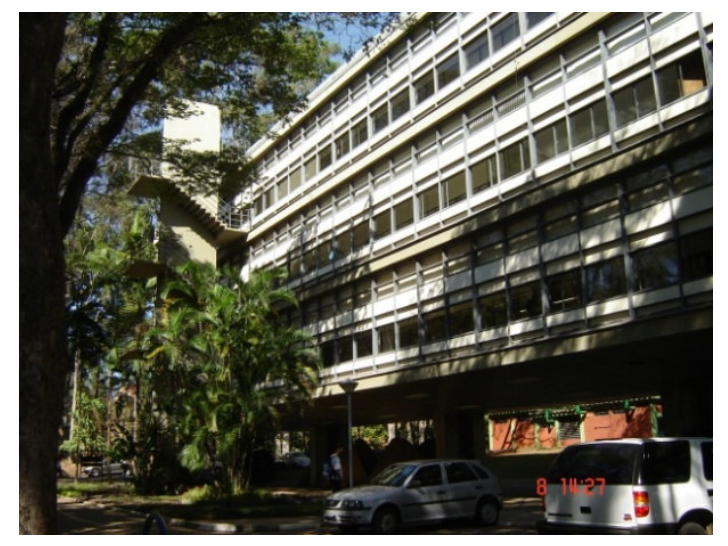

Figura 45 - Fachada norte do Bloco E1

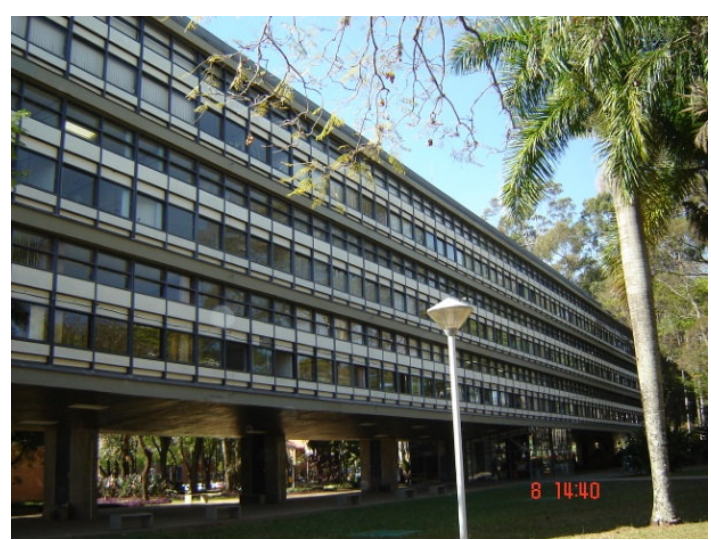

Figura 47 - Fachada sul do Bloco E1

Nas esquadrias há aberturas baixas e altas, a fim de promover uma circulação de ar permanente, mesmo quando a configuração interna com divisórias opacas não permitirem a ventilação cruzada. Possui também uma abertura na direção dos corpos dos ocupantes. Cada unidade de esquadria é dividida ao meio, de modo que uma parte possa correr sobre a outra para ventilar. Possui três faixas de ventilação que podem ser controladas de acordo com a necessidade.

As áreas transparentes foram colocadas de modo a promover uma iluminação uniforme no ambiente interno. Há faixas de iluminação baixas e altas. Encontra-se a seguir o projeto dessas esquadrias (figura 48). 


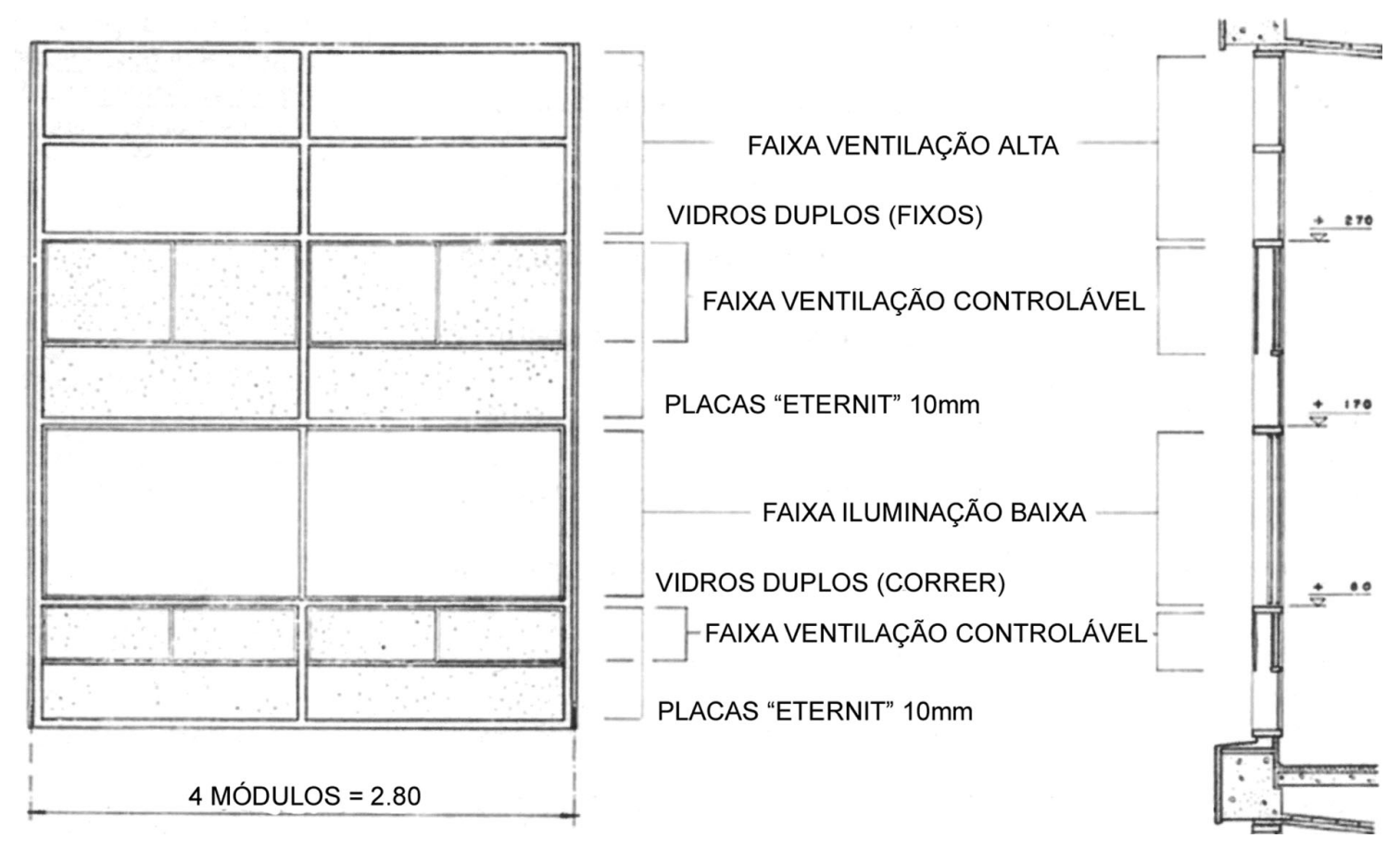

Figura 48 - Construção Bloco E1

Fonte - Araújo (2004)

O projeto de iluminação natural partiu de esquemas de otimização de iluminação, realizados com a ajuda de ábacos construídos por Mange. Pode-se visualizar um desses gráficos a seguir (figura 49). Nesse esquema o autor constrói as curvas de aclaramento referentes às janelas 1 e 2 , assim como sua soma. Considera como contribuição apenas uma face, a sul, dessa forma elimina quase que por completo a incidência solar diretamente nas áreas de trabalho. As janelas baixas e altas garantem a uniformidade.

Este gráfico é resultado de estudos teóricos realizados por Mange para cálculos de níveis de iluminâncias nos ambientes. É possível fazer uma comparação entre as curvas desenhadas por ele com base teórica e as curvas resultantes das medições realizadas nesta pesquisa. Esta comparação encontra-se no capítulo 6.2. - Níveis de lluminância. 


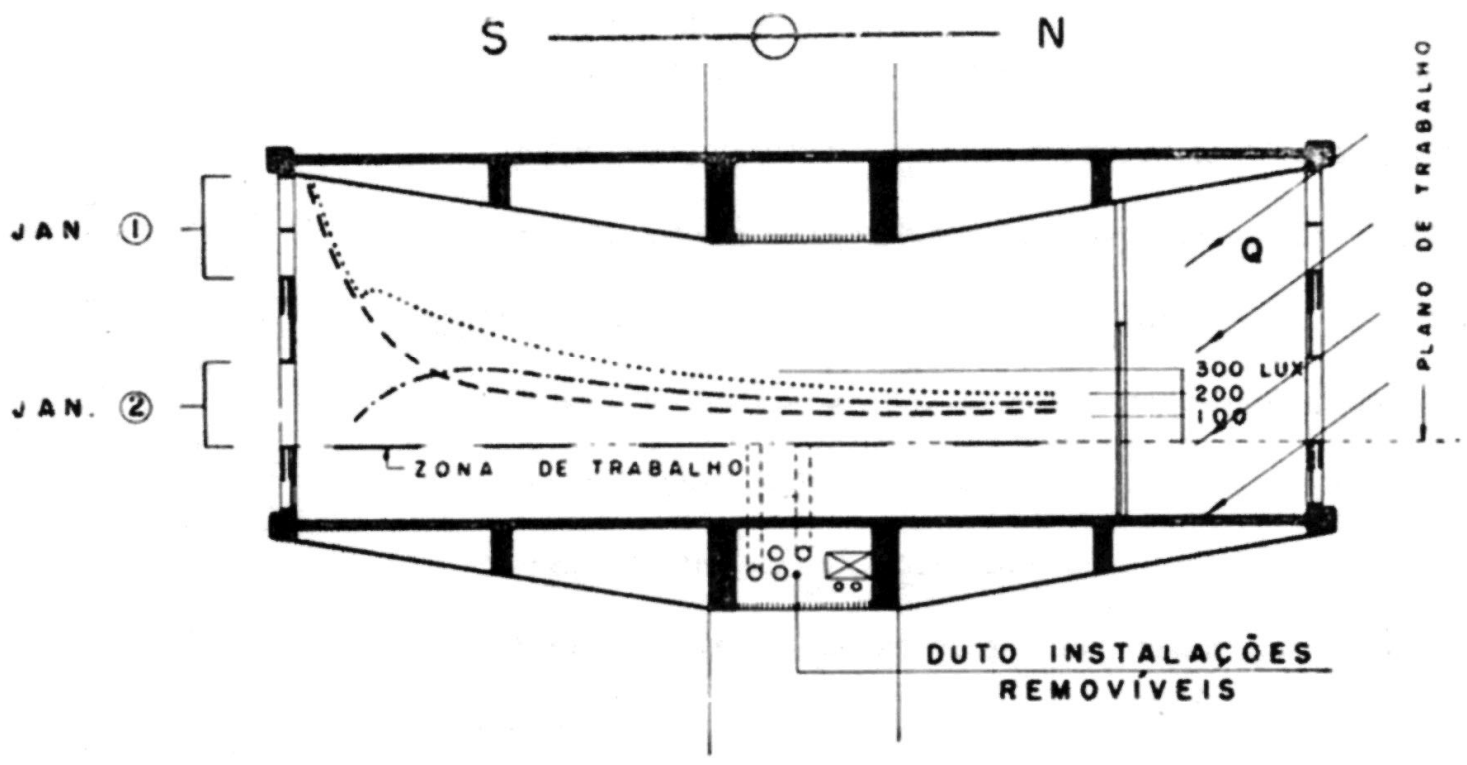

CURVAS DE ACLARAMENTO

CONTRIBUIGÃo DE UMA FACE

-.-.-.-.-JANELA I

- - - - - JANELA

Figura 49 - Gráfico para iluminação desenvolvido por Mange

Fonte - Mange et al. (1959)

Para a cobertura em terraço foi adotada solução que permite grande isolamento térmico, além de impermeabilização. Trata-se de um sistema composto por duas lajes, havendo um espaço vazio entre elas (figuras 50 e $51)$.

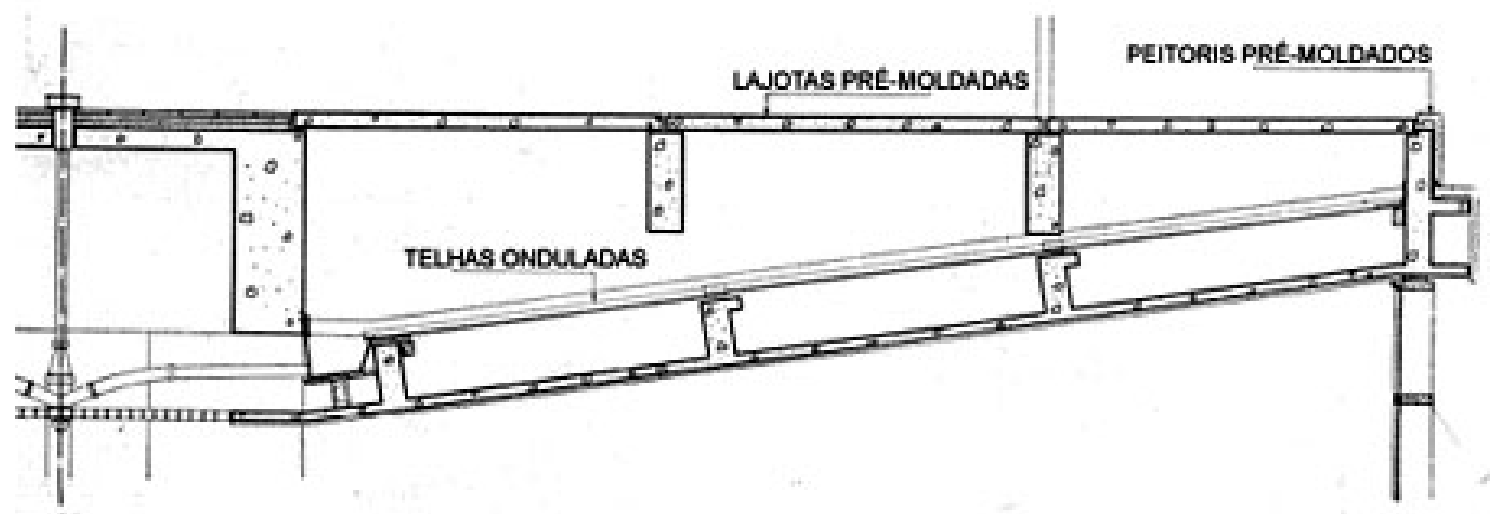

Figura 50 - Cobertura Bloco E1

Fonte - Duarte e Mange (1956) 


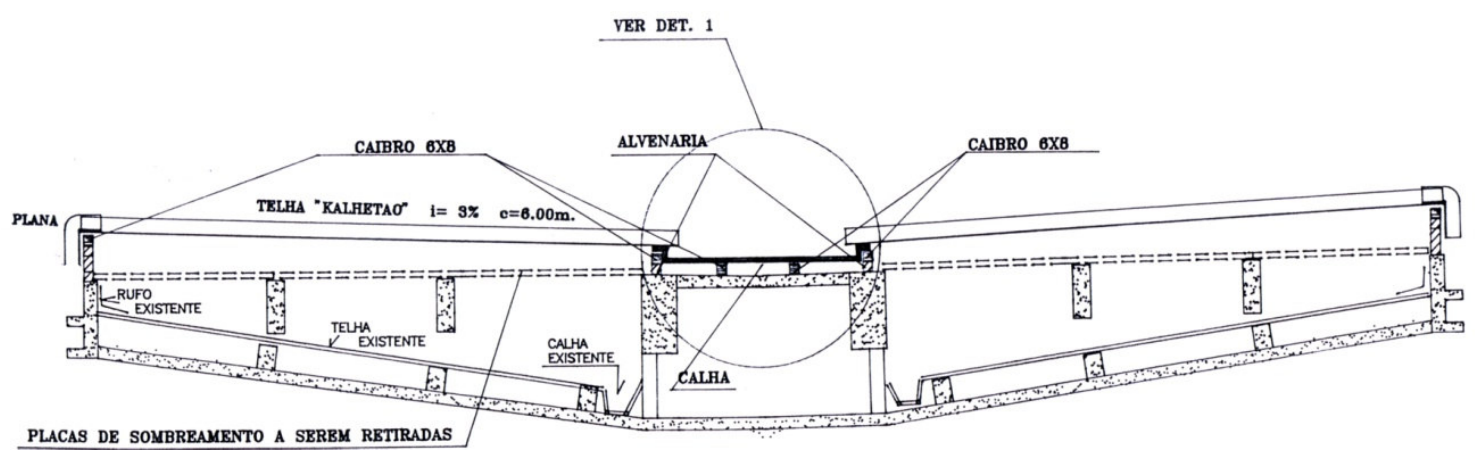

Figura 51 - Cobertura Bloco E1

Fonte - Duarte e Mange (1956)

As figuras 52 a 57 mostram imagens internas do Bloco E1 em dois períodos de utilização (logo após a sua construção e nos dias atuais). É possível identificar mudanças realizadas nas divisórias internas, que possuíam aberturas superiores para auxiliar na ventilação e na iluminação. No novo layout essa questão não foi considerada, na maioria dos ambientes há divisórias totalmente fechadas, sendo que em algumas salas há pequenas áreas envidraçadas, porém sem aberturas.

Também é possível verificar que atualmente está sendo feito o uso de persianas nas janelas localizadas na fachada norte, as quais permanecem fechadas constantemente, prejudicando iluminação e ventilação.

Outra questão que pode ser verificada (figuras 56 e 57) é a flexibilidade do edifício quanto ao uso, importante característica da Arquitetura Moderna, a qual teve seus preceitos seguidos no projeto do Bloco E1, contudo a questão do regionalismo e características climáticas locais não foi deixada de lado, ao contrário, nesse caso, teve uma proporção de igual tamanho, senão maior. 


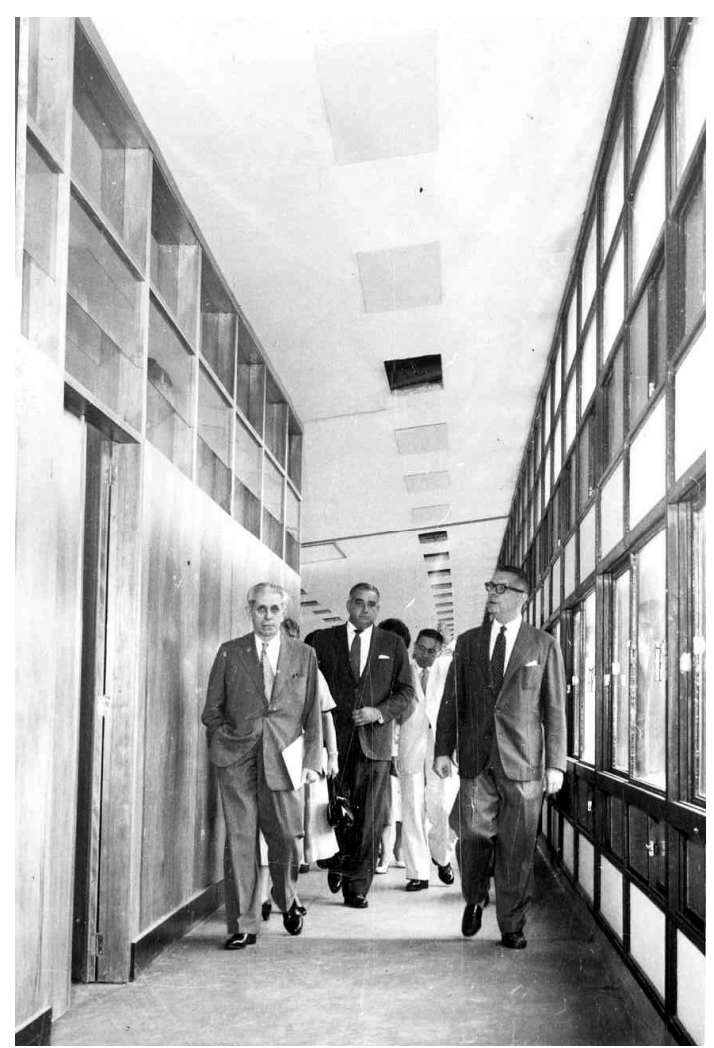

Figura 52 - Interior do Bloco E1 - [ca. 1960]

Fonte - BLOCO E1: fotos diversas (2005)

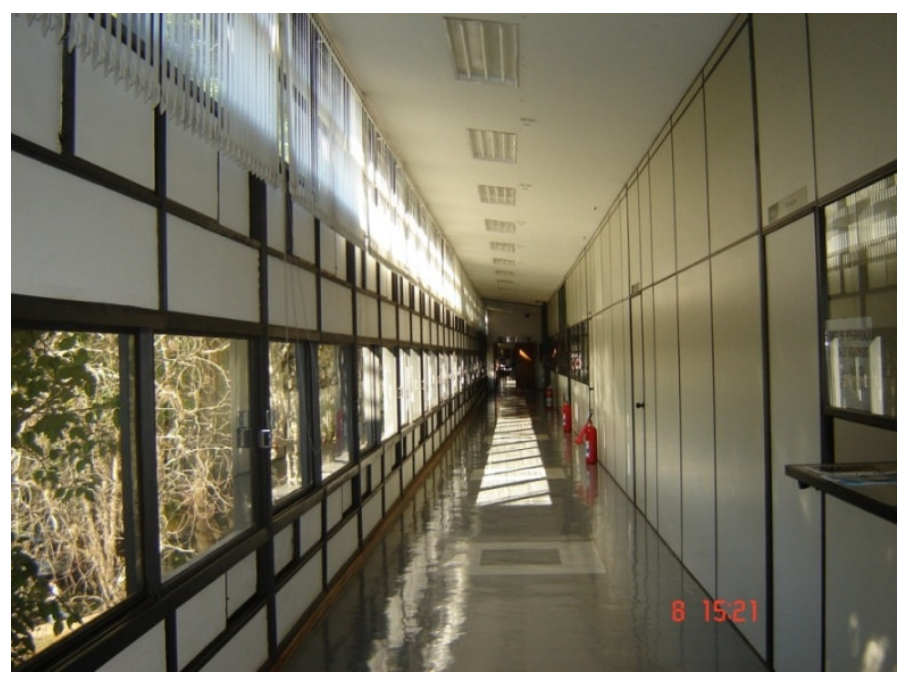

Figura 53 - Interior do Bloco E1 - 2007 


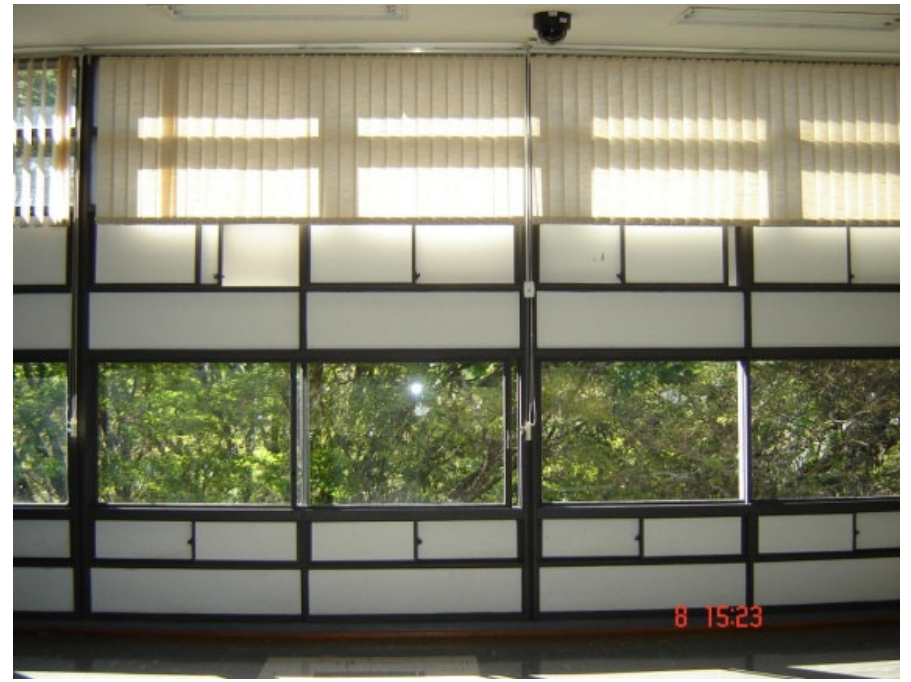

Figura 54 - Interior do Bloco E1 - 2007

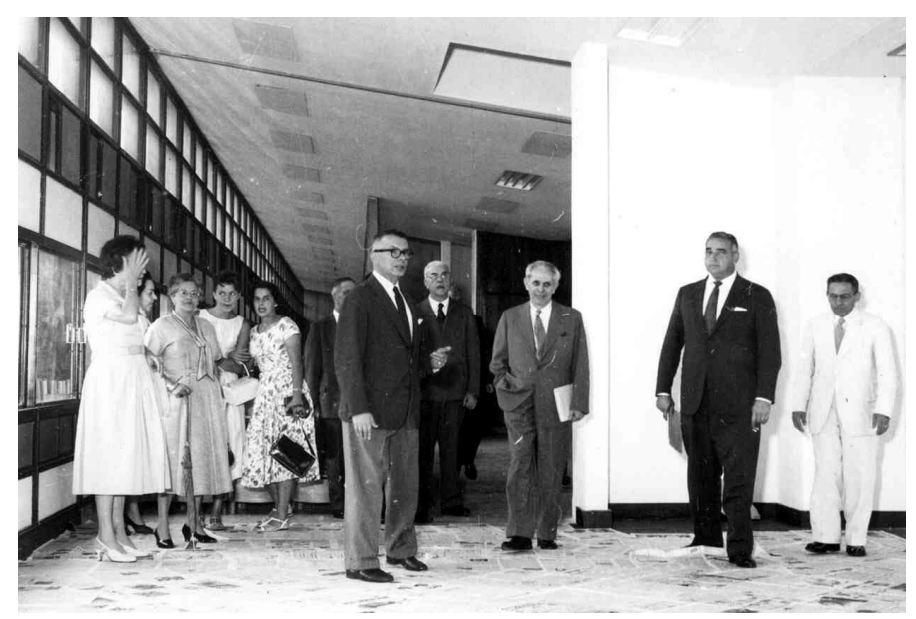

Figura 55 - Interior do Bloco E1 - [ca. 1960]

Fonte - BLOCO E1: fotos diversas (2005)

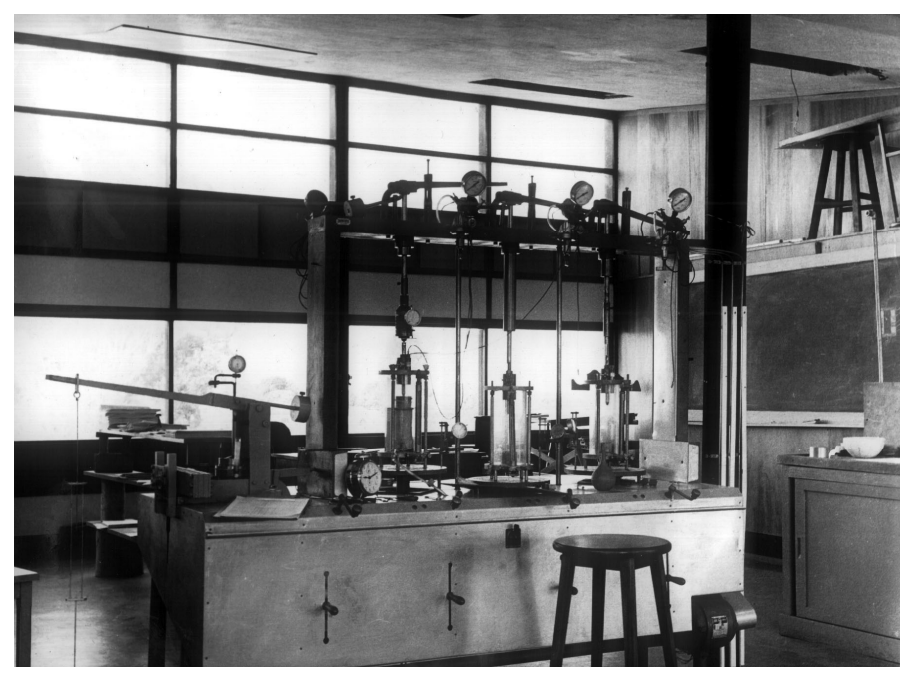

Figura 56 - Interior do Bloco E1 - [ca. 1960]

Fonte - BLOCO E1: fotos diversas (2005) 


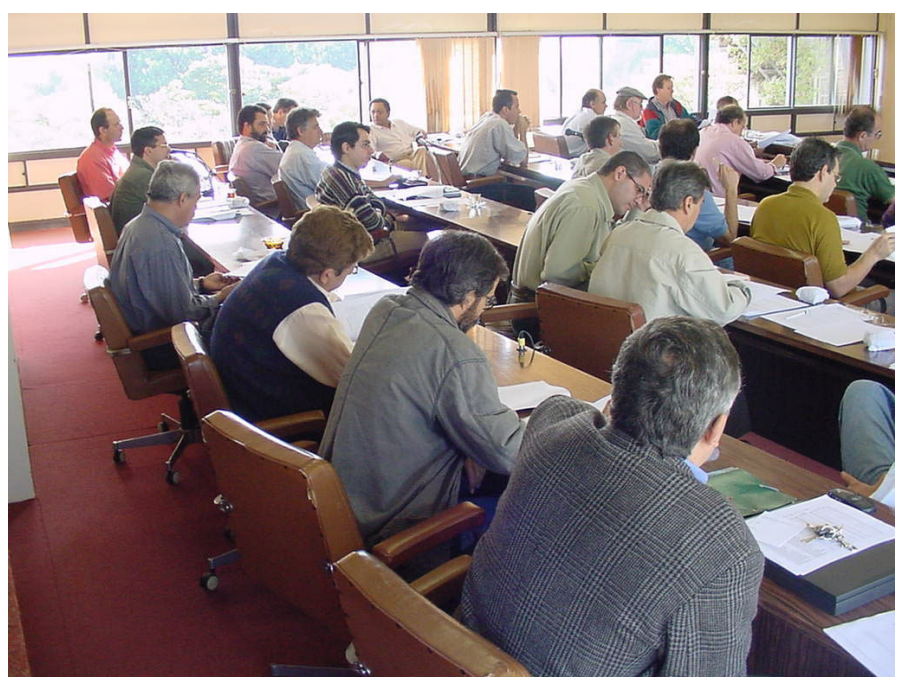

Figura 57 - Interior do Bloco E1 - [200-]

Fonte - BLOCO E1: fotos diversas (2005) 



\section{Materiais e Métodos}

Neste capítulo estão descritos os materiais e métodos utilizados na aplicação dos questionários e nas medições in loco.

\subsection{Questionários}

O questionário foi aplicado a 60 pessoas que trabalham no Bloco E1, o que representa praticamente a totalidade de funcionários do prédio. Foi feita entre estes uma divisão por sexo e faixa etária.

Foram aplicados questionários que averiguaram estágios de satisfação dos usuários através de perguntas relativas à sensação de conforto térmico, satisfação quanto à iluminação natural e aceitação/preferência entre as estratégias existentes.

Para a avaliação da sensação de conforto térmico, foi utilizada a escala subjetiva de calor Ashrae, que é a seguinte: muito frio (-3), frio (-2), levemente frio $(-1)$, neutralidade térmica $(0)$, levemente quente (1), quente (2), muito quente (3). Foram realizadas perguntas relacionadas com as sensações de conforto nos períodos do verão e do inverno, a necessidade de utilização da iluminação artificial durante o expediente de trabalho, a iluminação natural nas mesas de trabalho e a satisfação quanto à transparência proporcionada pelas fachadas envidraçadas.

O apêndice $B$ apresenta o modelo deste questionário. 


\subsection{Medições in loco}

O edifico analisado localiza-se na cidade de São Carlos, região central do Estado de São Paulo a 22 01' de latitude sul, 47 53' de longitude e 856 m de altitude.

Segundo Vecchia (1989) o perfil climático de São Carlos é caracterizado pela existência de verão quente e úmido e inverno seco, com predominância de amplitudes térmicas acentuadas durante todo o ano.

No verão, durante o dia, a média das temperaturas máximas é de $31.7^{\circ} \mathrm{C}$, e durante a noite, a média das temperaturas mínimas é de $14.0{ }^{\circ} \mathrm{C}$, com uma amplitude em torno de $18{ }^{\circ} \mathrm{C}$.

O inverno possui valores baixos de umidade relativa do ar (em torno de $56,2 \%$ ). As menores temperaturas ocorrem durante a noite (a média das mínimas é de $7^{\circ} \mathrm{C}$ ), os dias são considerados quentes e a amplitude térmica atinge valores superiores a $20^{\circ} \mathrm{C}$.

Para a realização das medições in loco foram escolhidos dois ambientes do E1, a sala da Assistência Administrativa situada no primeiro andar e a Antesala da Congregação no terceiro andar. Nas figuras 58 e 59 estão identificados os ambientes.

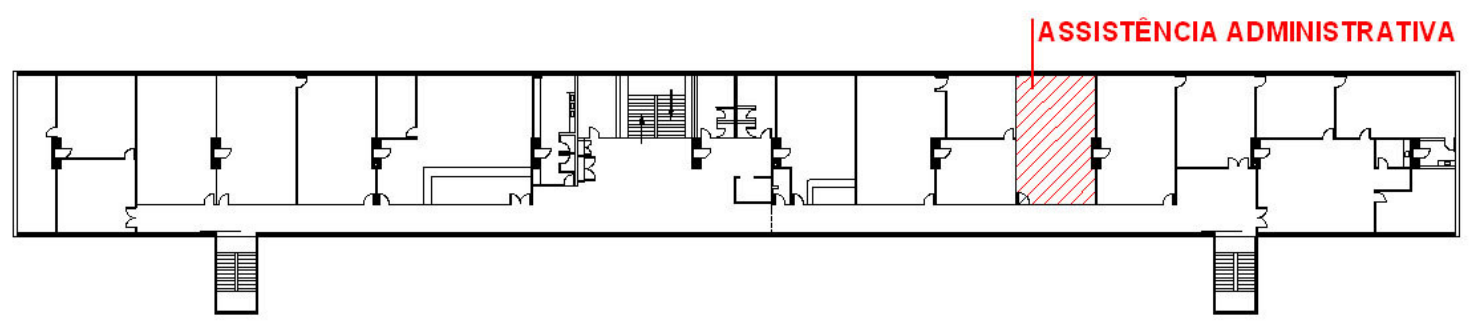

$\nabla \mathbf{N}$

Figura 58 - Planta $1^{\circ}$ pavimento - Bloco E1

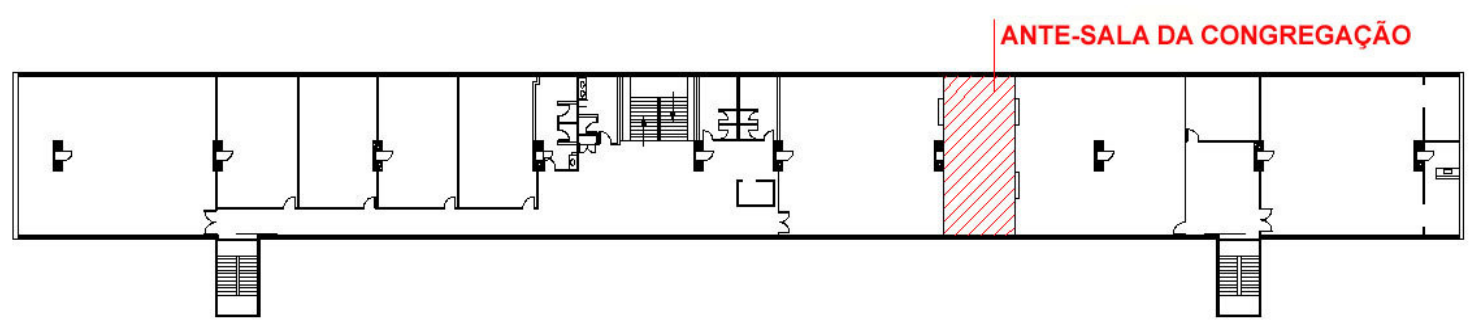

$\nabla \mathbf{N}$

Figura 59 - Planta $3^{\circ}$ pavimento - Bloco E1 
Na sala da Assistência Administrativa trabalham três pessoas em horário integral das 8:00 às 18:00, com intervalo para almoço. O layout é composto basicamente por três mesas e alguns arquivos baixos. Está limitada por quatro fechamentos, sendo a comunicação direta com o exterior realizada através da fachada sul, os fechamentos laterais são divisórias e do lado da fachada norte há um corredor e uma divisória com uma faixa central em vidro (figura 60), não havendo aberturas. As divisórias e o teto são de cor clara e o piso de madeira.

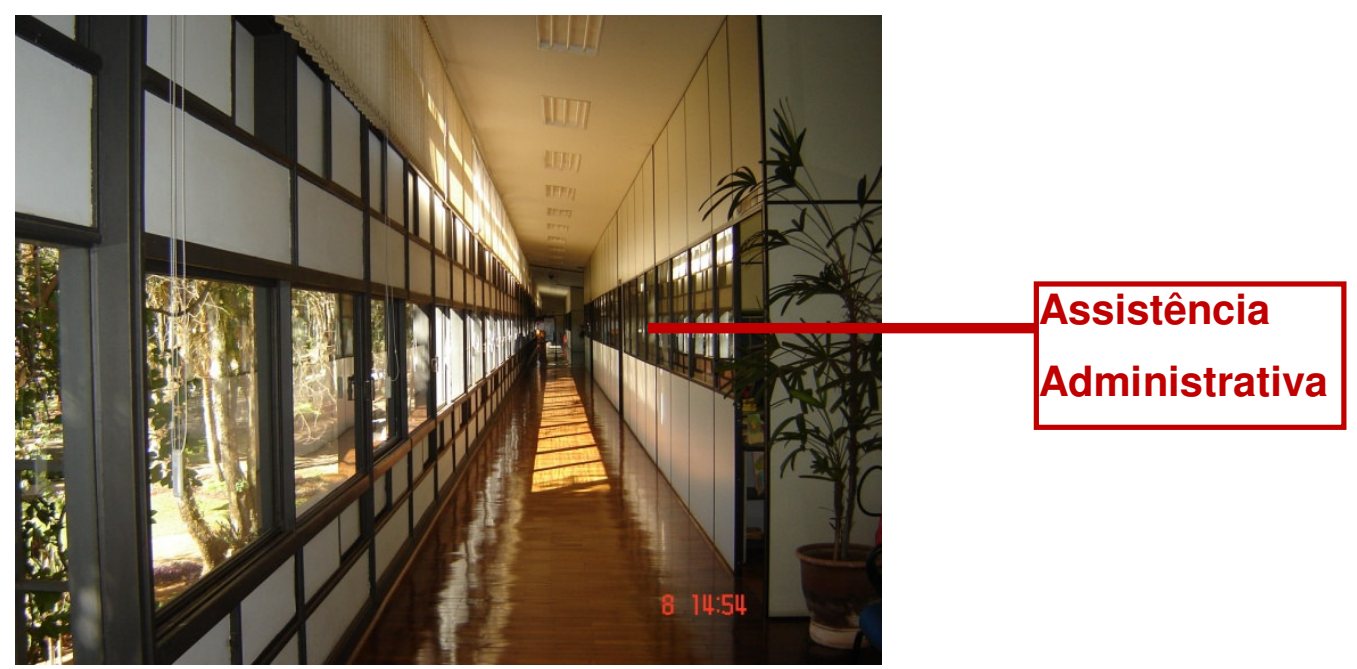

Figura 60 - Divisórias $1^{\circ}$ pavimento - Bloco E1

A Ante-sala da Congregação não possui um uso permanente. O seu layout também não é permanente, sendo adequado a cada ocasião, normalmente são inseridos apenas mesas e cadeiras. Nos períodos de medições havia três painéis, conforme mostrado na figura 61, os quais foram utilizados como delimitação das medições. Não possui corredores voltados para a fachada norte, sendo a comunicação direta com o exterior realizada através das fachadas norte e sul. O teto é de cor clara e o piso de madeira. 


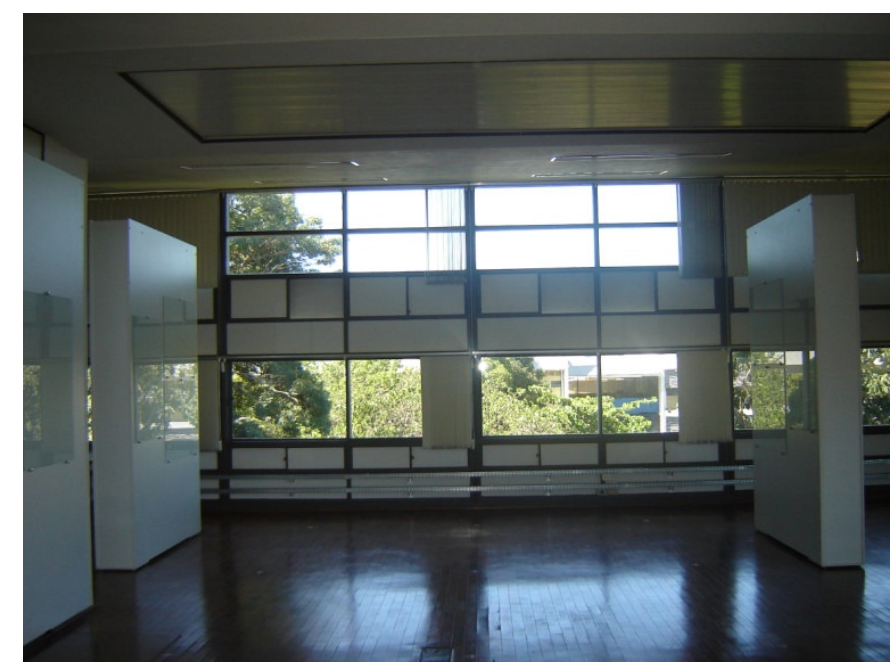

Figura 61 - Ante-sala da Congregação

\subsubsection{Níveis de iluminância}

As medições foram realizadas em dois períodos do ano (janeiro e julho) e em três horários diferentes ao longo do dia: pela manhã, no início da tarde e no final da tarde. Os procedimentos foram seguidos de acordo com ABNT (2005d).

Foi utilizado como equipamento um luxímetro da marca Instrutherm, modelo LX-102 light meter (figura 62), que realiza medições de 0 a 50.000 lux, em um tempo de resposta de $0,4 \mathrm{~s}$.

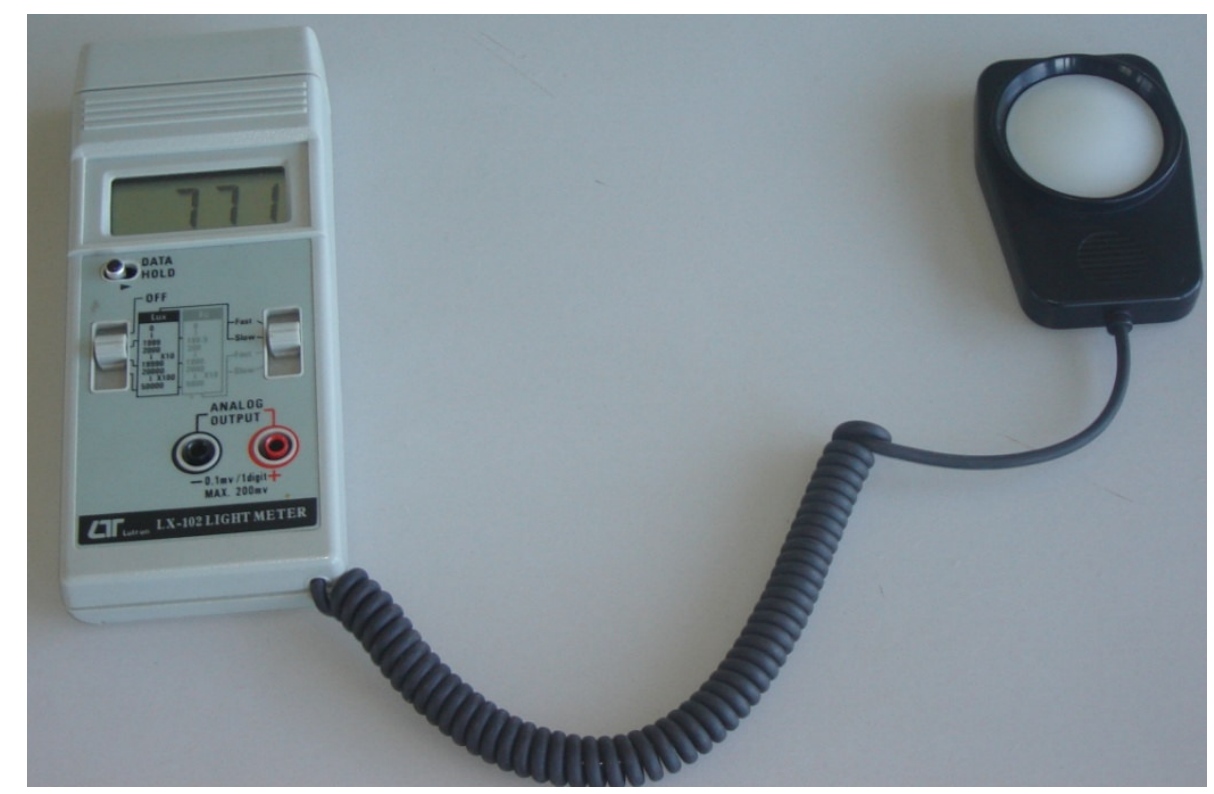

Figura 62 - Luxímetro utilizado 


\subsubsection{Variáveis ambientais}

As medições das variáveis ambientais englobaram temperatura, umidade relativa, velocidade relativa do ar e temperatura de globo. Estão associadas à determinação dos índices, encontrados na ISO 7730/2005, PMV (voto médio estimado) e PPD (percentagem de pessoas insatisfeitas).

Foi utilizado como equipamento o Confortímetro SENSU (figuras 63 e 64), construído pela Universidade Federal de Santa Catarina, que mede temperatura do ar, umidade relativa, velocidade do ar e temperatura de globo. O seu sistema é baseado em um micro computador PC, que conectado a um monitor, pode ser usado como um micro qualquer. Os seus dados, mostrados em um display alfa-numérico, são automaticamente registrados em disco rígido em formato "txt", podendo ser descarregados em um disquete. Ele possui um software para cálculo dos índices PMV e PPD, o qual roda em EXCEL.

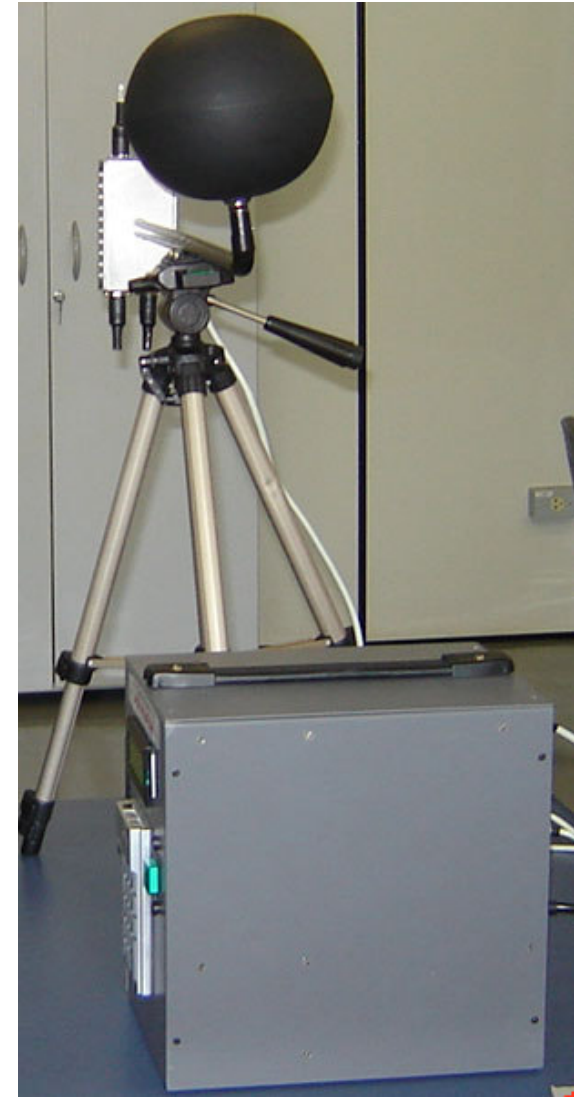

Figura 63 - Confortímetro Sensu

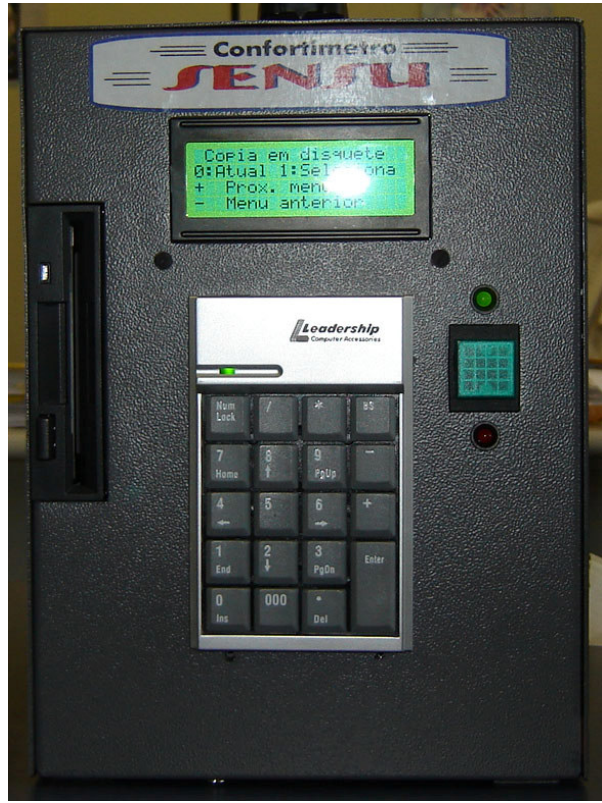

Figura 64 - Confortímetro Sensu 
Os dados climáticos externos foram coletados através de uma estação meteorológica, situada próxima ao Bloco E1 (figura 65), localizada dentro do campus da EESC-USP, ao lado do Laboratório de Construção Civil, pertencente ao Departamento de Arquitetura e Urbanismo. (figura 66).

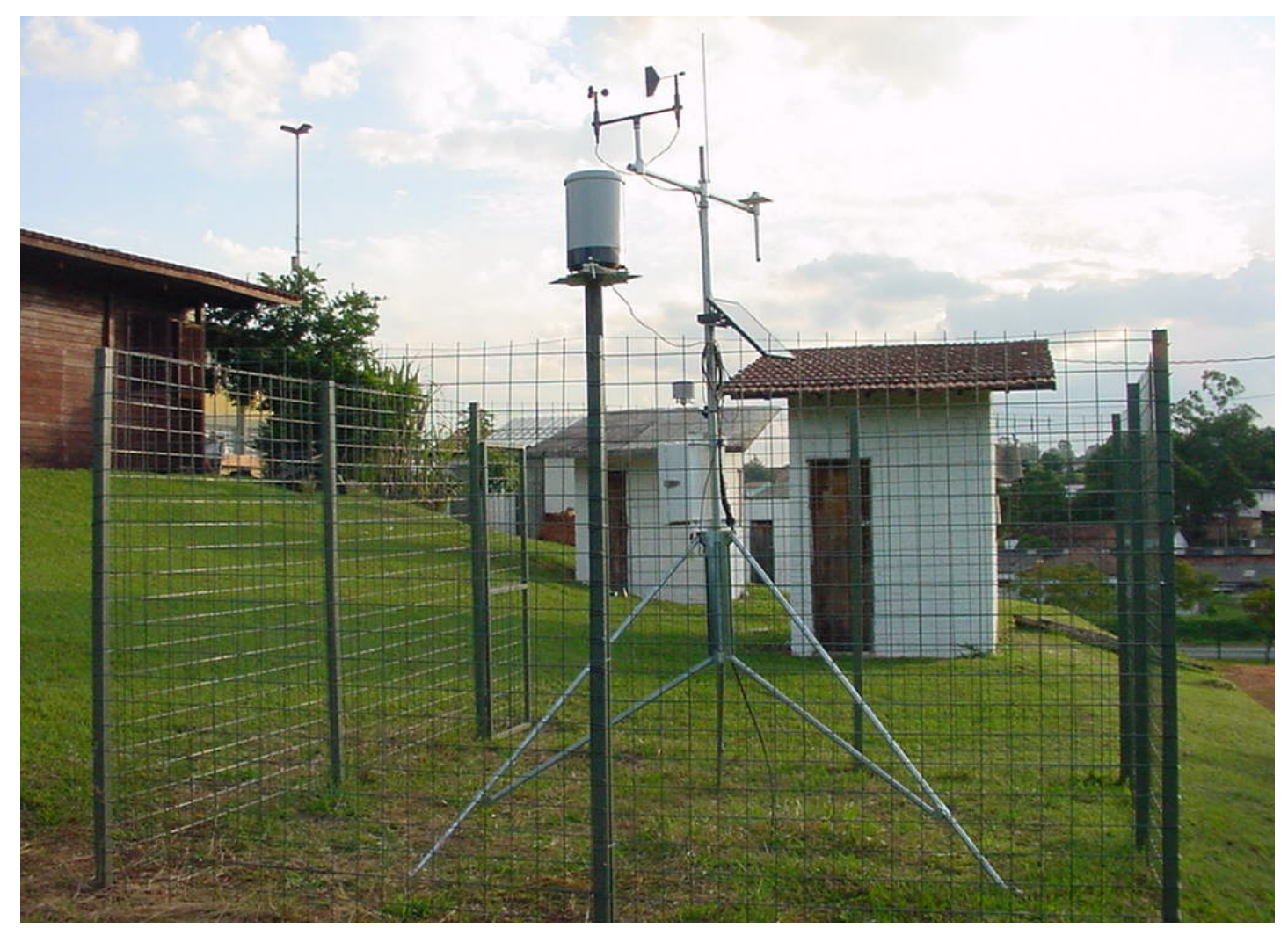

Figura 65 - Estação meteorológica EESC-USP 


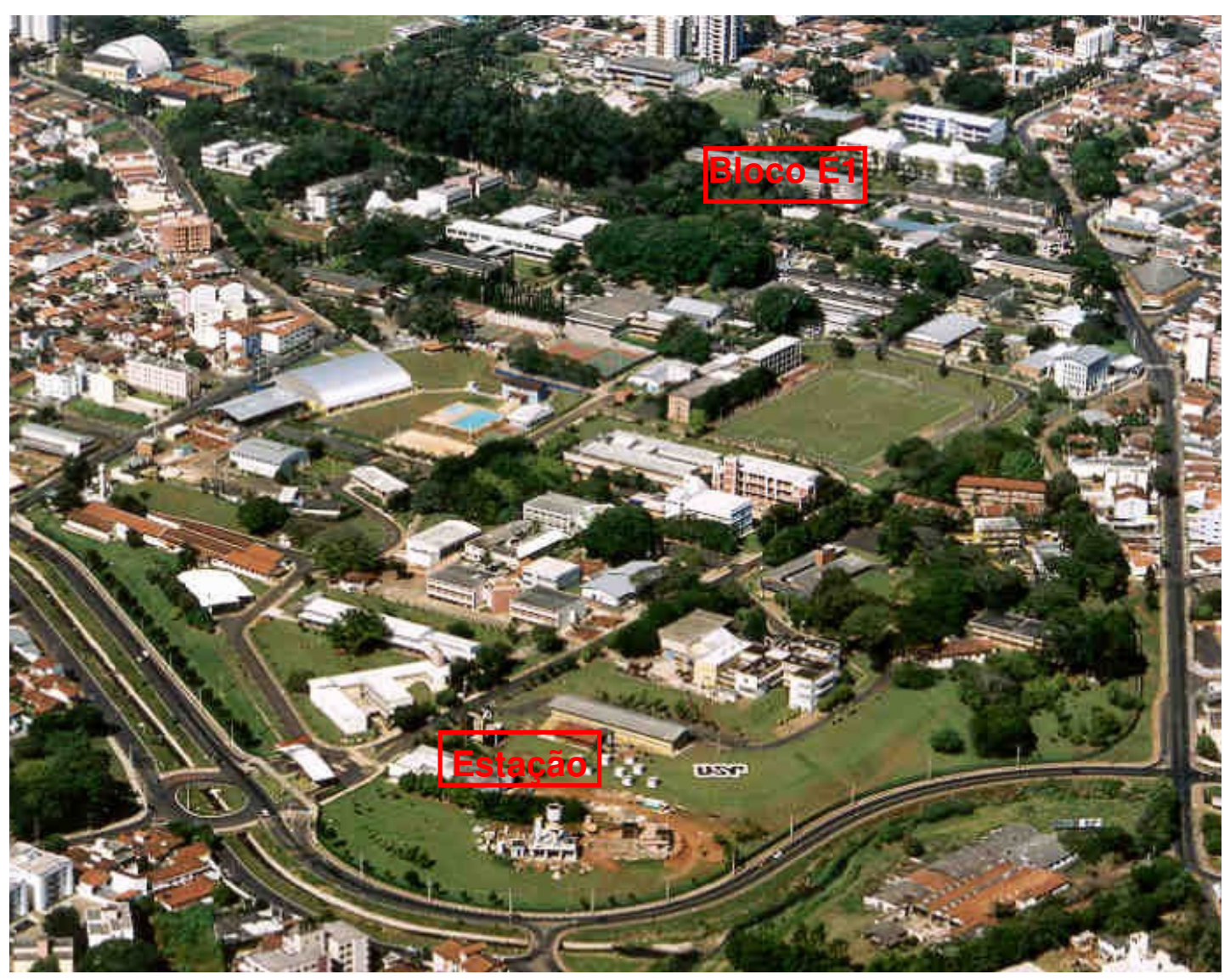

Figura 66 - Foto aérea campus São Carlos - USP

Fonte - BLOCO E1: fotos diversas (2005)

Foram feitas medições em quatro períodos:

- Período 1

Assistência Administrativa: 14 a 17 de novembro de 2006.

Ante-sala da Congregação: 21 a 24 de novembro de 2006.

- Período 2

Assistência Administrativa: 05 a 08 de março de 2007.

Ante-sala da Congregação: 12 a 15 de março de 2007.

- Período 3

Assistência Administrativa: 11 a 14 de junho de 2007.

Ante-sala da Congregação: 31 de maio a 03 de junho de 2007.

- Período 4

Assistência Administrativa: 26 a 29 de junho de 2007.

Ante-sala da Congregação: 05 a 08 de julho de 2007.

Para cada período de medição foi escolhido um dia para a realização de gráficos para análise, sendo que todos os dias dos quatro períodos foram 
tabulados. A escolha do dia seguiu o seguinte critério: maior média das temperaturas externas nos períodos 1 e 2 , e menor média das temperaturas externas nos períodos 3 e 4 . Para o período 1 foram escolhidos dois dias para a Ante-sala da Congregação, tendo como diferencial a abertura das janelas.

Para a sala da Assistência Administrativa, a abertura das janelas ocorreu conforme a utilização de seus ocupantes, sendo que nessa sala trabalham três mulheres. Para a Ante-sala da Congregação, por não possuir ocupantes fixos, foram feitas medições com diferentes possibilidades de abertura das janelas, como mostra a tabela 5, sendo sempre considerados quatro módulos de janelas em cada fachada. Essas aberturas foram feitas considerando as características dos períodos, nos mais frios, optou-se pelas janelas fechadas.

Cada módulo de janela do Bloco E1 possui três faixas que podem ser abertas para ventilação (figura 67), sendo que a área de abertura de cada faixa por módulo de janela é:

- Faixa superior $=0,078 \mathrm{~m}^{2}$

- Faixa central $=1,170 \mathrm{~m}^{2}$

- Faixa inferior $=0,078 \mathrm{~m}^{2}$

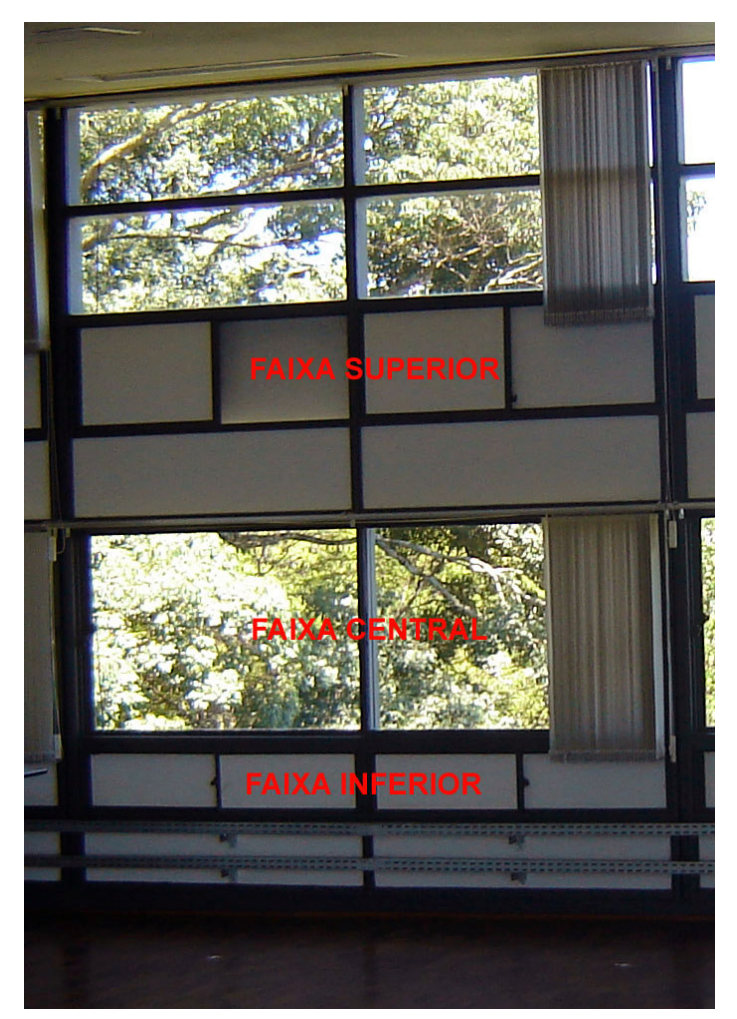

Figura 67 - Módulo de janela do Bloco E1 
Tabela 5 - Abertura de janelas durante as medições - Ante-sala da Congregação

\begin{tabular}{|c|l|c|}
\hline Dia de medição & \multicolumn{1}{|c|}{ Abertura das janelas } & Área de abertura $\left(\mathbf{m}^{\mathbf{2}}\right)$ \\
\hline $23 / 11 / 06$ & Janelas fechadas & - \\
\hline $24 / 11 / 06$ & $\begin{array}{l}\text { Janelas abertas: } \\
\text { Faixa central - fachadas norte e sul }\end{array}$ & 9,360 \\
\hline & Janelas abertas: & \\
\hline $13 / 03 / 07$ & Faixa central - fachadas norte e sul & 10,608 \\
\hline $03 / 06 / 07$ & Faixa inferior - fachada norte & \\
\hline $07 / 07 / 07$ & Janelas fechadas & - \\
\hline
\end{tabular}

Para o dia 13/03/07, em que as janelas foram abertas utilizando as três faixas de aberturas das janelas, foi feita a abertura na faixa inferior na fachada norte considerando a direção do vento, e assim otimizando a entrada de ar frio pela faixa inferior e saída do ar quente pela faixa superior.

As medições foram feitas durante todo o dia em um intervalo de quatro minutos, contudo para as tabulações e gráficos foi considerado um intervalo de meia hora, das 8h00min às $18 \mathrm{~h} 00 \mathrm{~min}$, que ó o período do expediente de trabalho.

Essas medições realizadas estão associadas à determinação dos índices, encontrados na ISO 7730/2005, PMV (voto médio estimado) e PPD (percentagem de pessoas insatisfeitas). Dessa forma, foram gerados esses índices para análises a partir das medições das variáveis ambientais, considerando também as variáveis pessoais: atividade desenvolvida e vestimenta utilizada. Para os períodos 1 e 2 foram considerados os valores de $65 \mathrm{~W} / \mathrm{m}^{2}$ para atividade metabólica (atividade de escritório) e 0.49 clo para índice de vestimenta (roupas utilizadas em períodos de temperaturas altas) . Para os períodos 3 e 4 foram considerados os valores de $65 \mathrm{~W} / \mathrm{m}^{2}$ para atividade metabólica (atividade de escritório) e 0.86 clo para índice de vestimenta (roupas utilizadas em períodos de temperaturas baixas). 


\subsection{Forma de análise dos resultados}

Foram realizados gráficos e tabulações para os questionários e para as medições.

Para o conforto térmico, foram gerados os índices de PMV (voto médio estimado) e PPD (percentagem de pessoas insatisfeitas), e comparados com a norma ISO 7730/2005.

Para a iluminação, os níveis de iluminância foram comparados com a norma NBR 5413/1992.

As análises possuem a finalidade de verificar a real eficácia das estratégias propostas no Bloco E1, indicando exemplos para adaptações e melhorias quanto ao conforto térmico e à iluminação do ambiente construído, e redução nos gastos energéticos das edificações. 


$$
1
$$




\section{RESULTADOS E DISCUSSÕES}

\subsection{Questionários}

O questionário foi aplicado a 60 pessoas, para as quais foi realizada uma divisão por sexo e por faixa etária, representadas abaixo (figuras 68 e 69). A atividade metabólica desenvolvida por todos os entrevistados é leve e o tipo de atividade visual é de escritório.

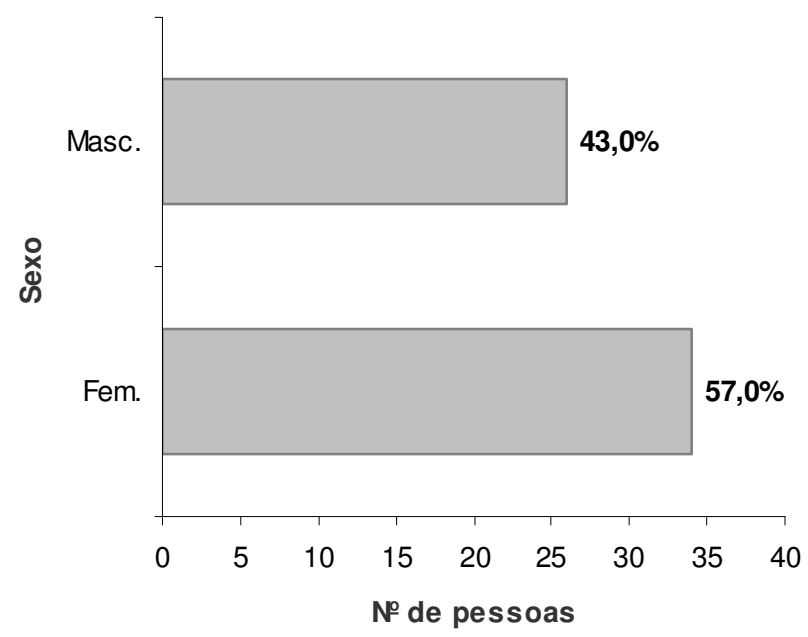

Figura 68 - Questionários - divisão por sexo 


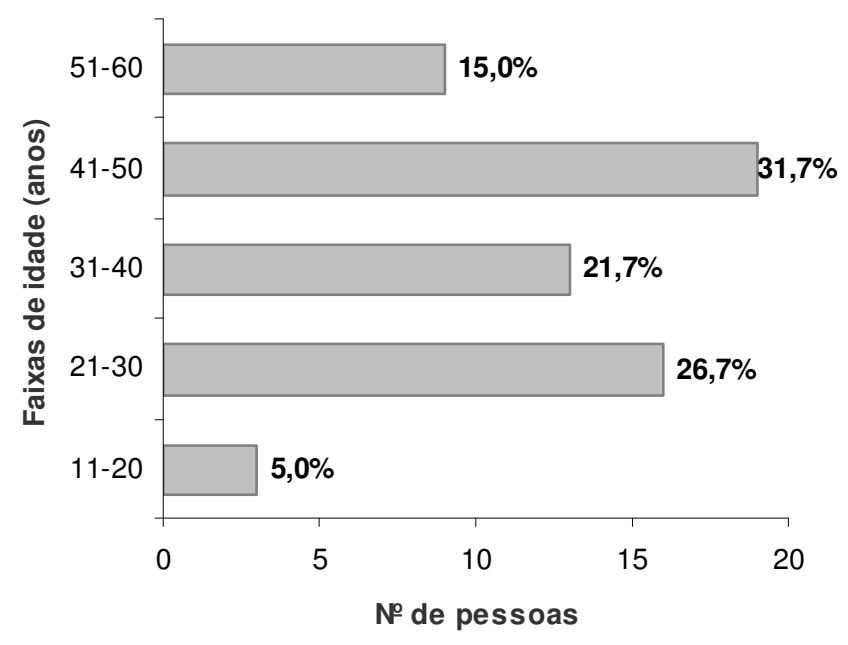

Figura 69 - Questionários - faixa etária

As figuras 70 e 71 representam as respostas dos entrevistados quanto à temperatura em sua sala de trabalho, respectivamente no verão e no inverno. Foi utilizada a escala subjetiva de calor ISO 7730 : muito frio (-3), frio (-2), levemente frio (-1), neutralidade térmica (0), levemente quente (1), quente (2), muito quente (3).

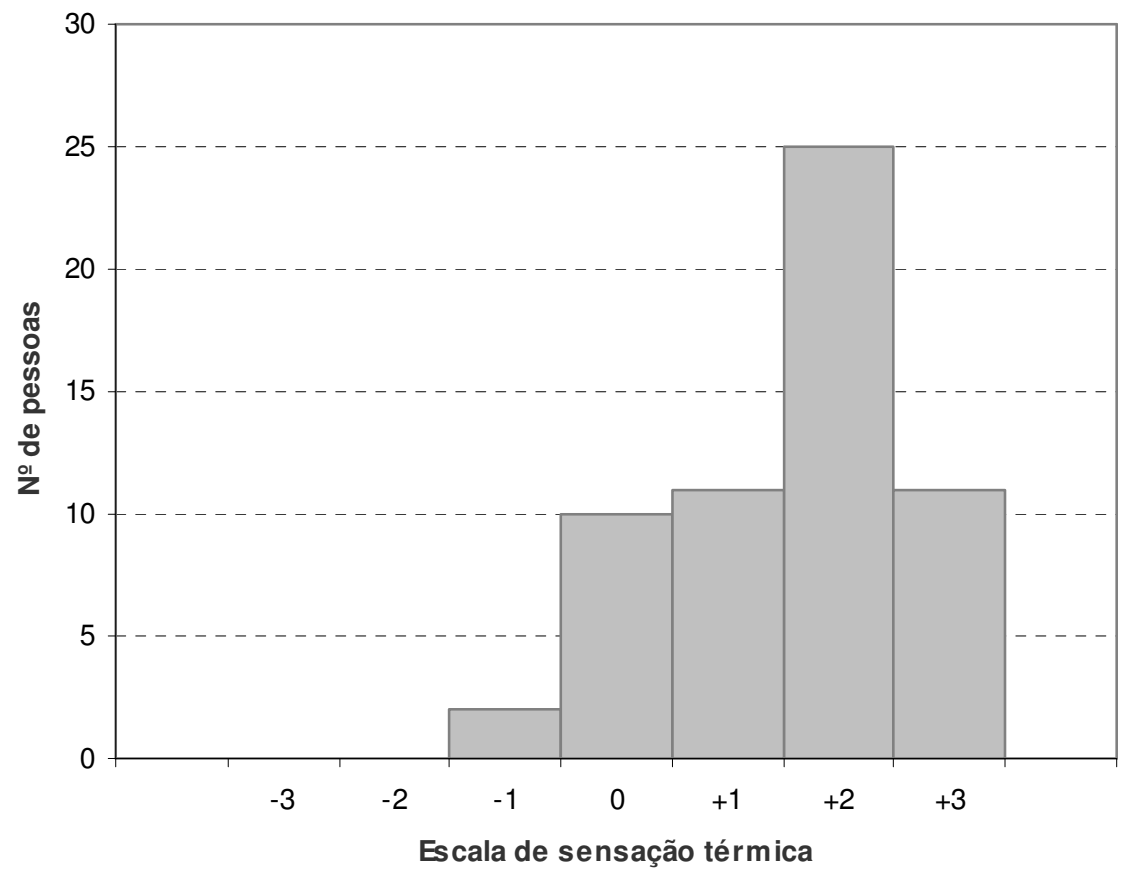

Figura 70 - Sensação térmica - verão 


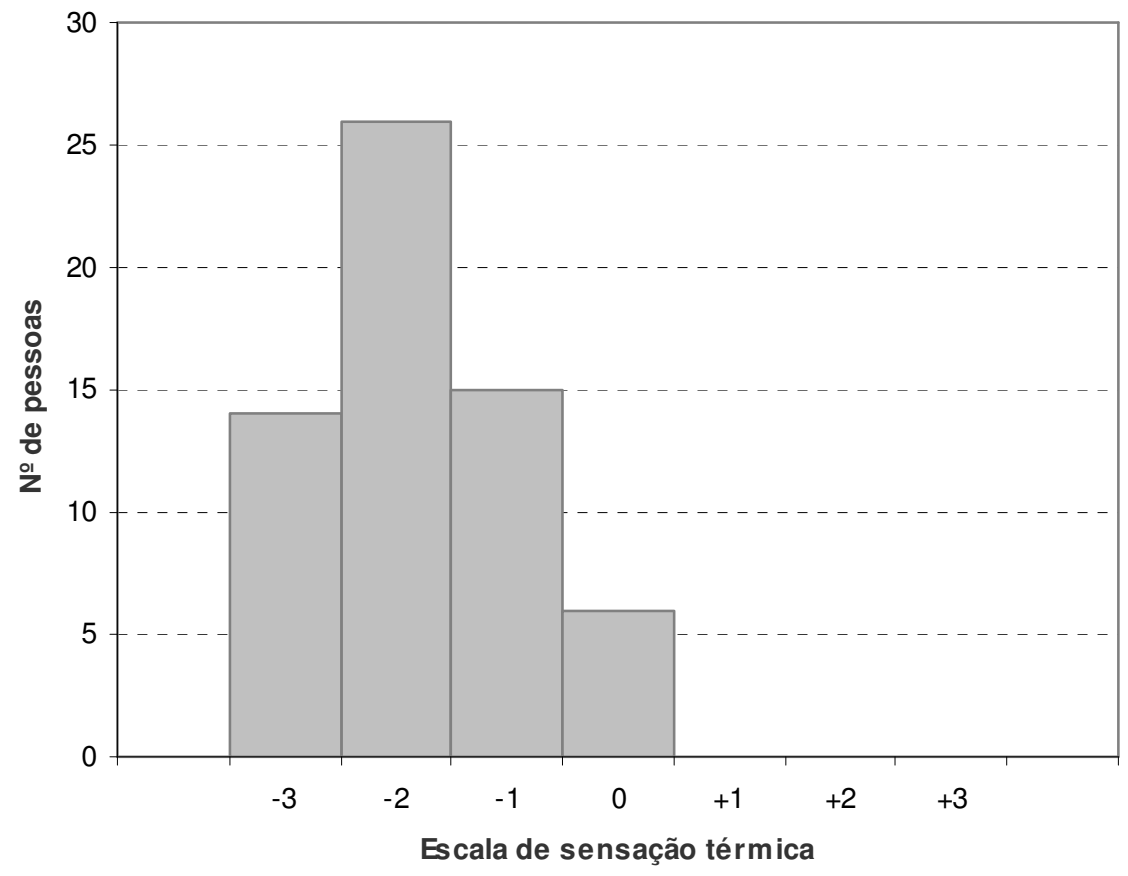

Figura 71 - Sensação térmica - inverno

As figuras 72 e 73 representam gradação de temperatura por divisão de sexo.

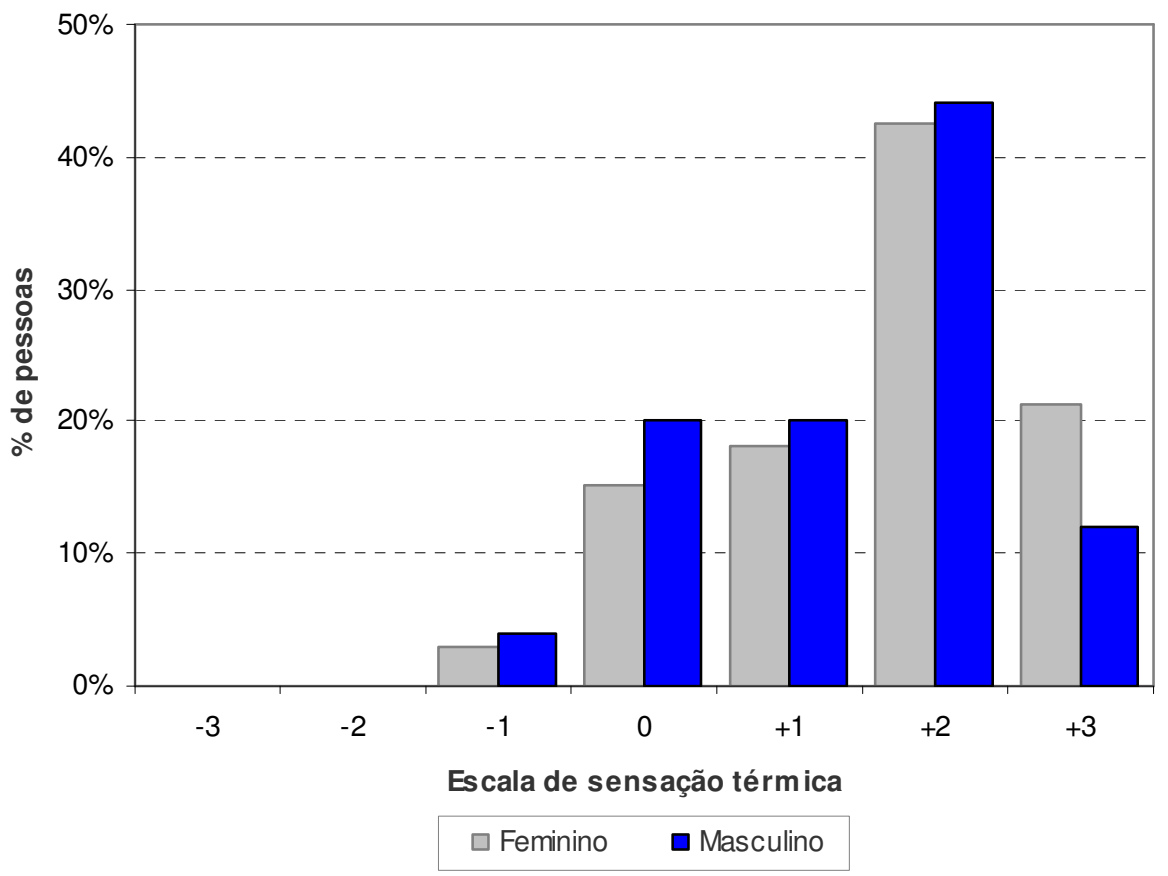

Figura 72 - Sensação térmica - verão 


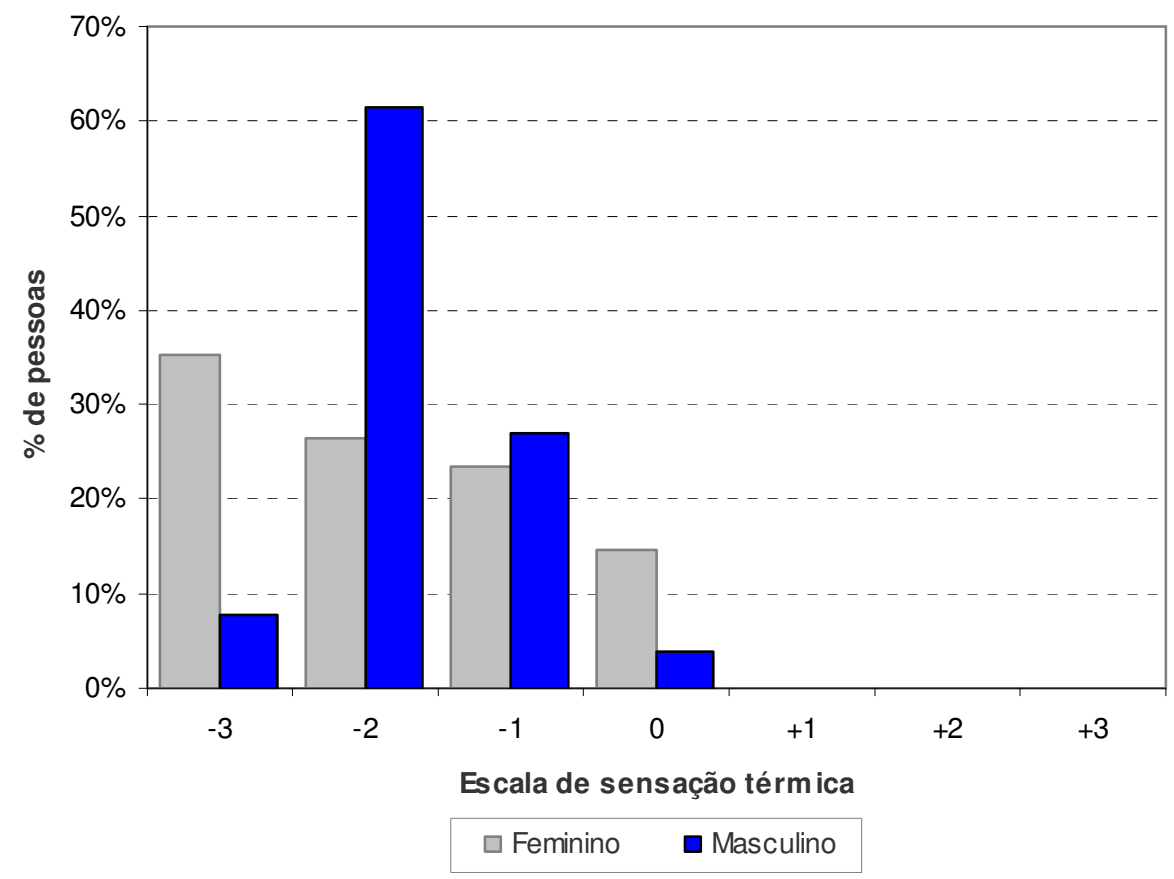

Figura 73 - Sensação térmica - inverno

As figuras 74 e 75 representam a freqüência e periodicidade do acendimento de lâmpadas durante o expediente de trabalho no verão.

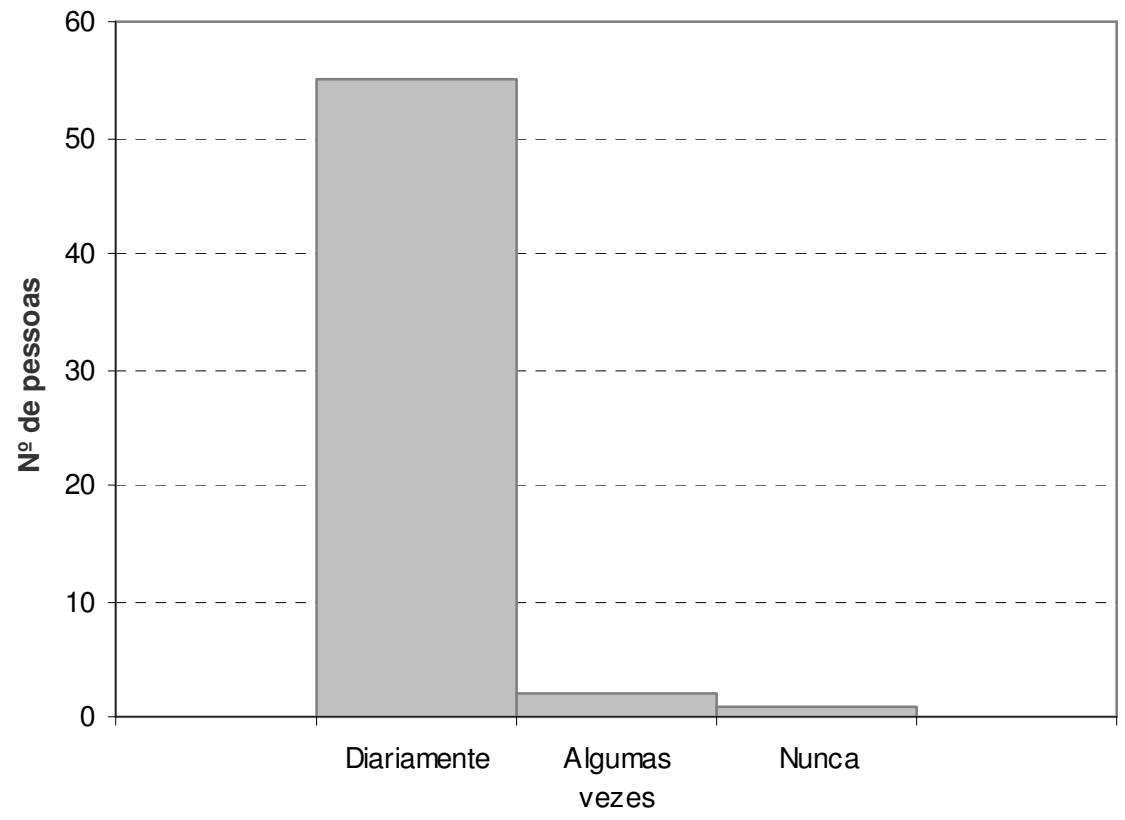

Freqüência

Figura 74 - Uso da iluminação artificial - verão 


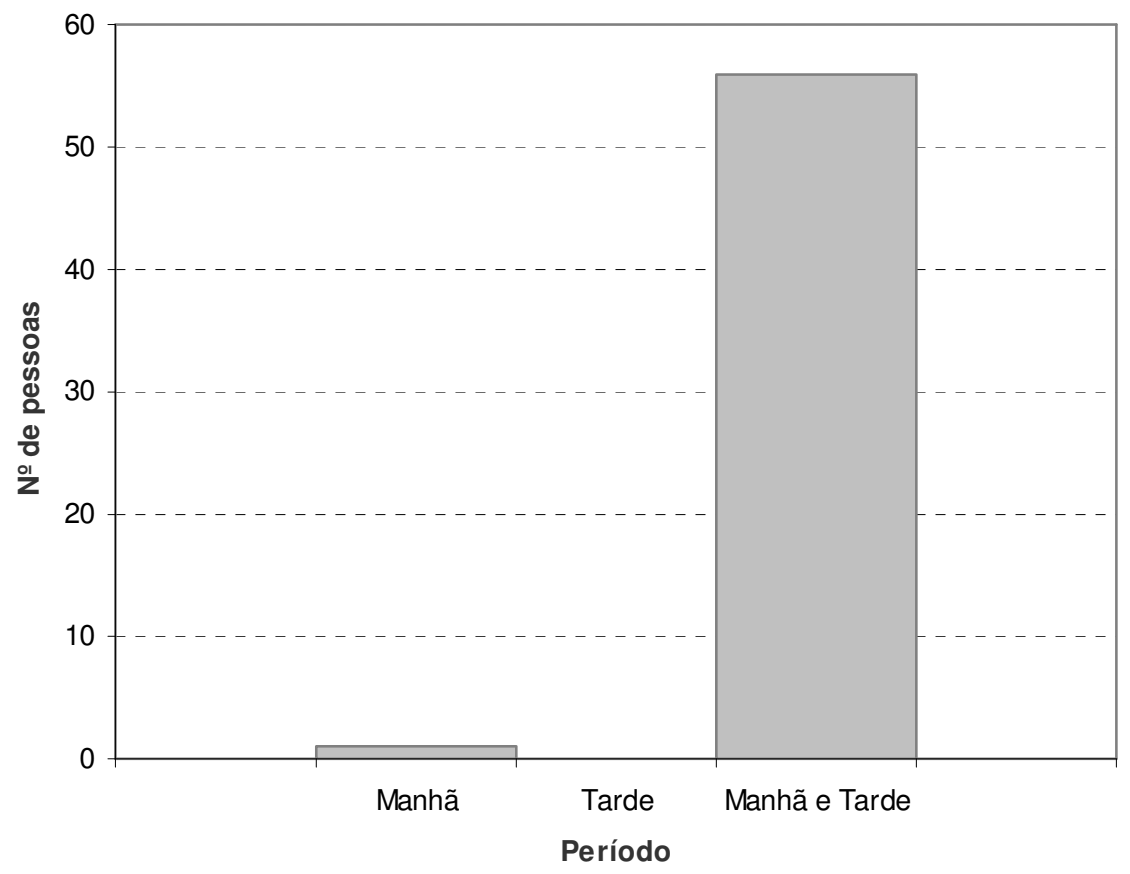

Figura 75 - Uso da iluminação artificial - verão

As figuras 76 e 77 representam a freqüência e periodicidade do acendimento de lâmpadas durante o expediente de trabalho no inverno.

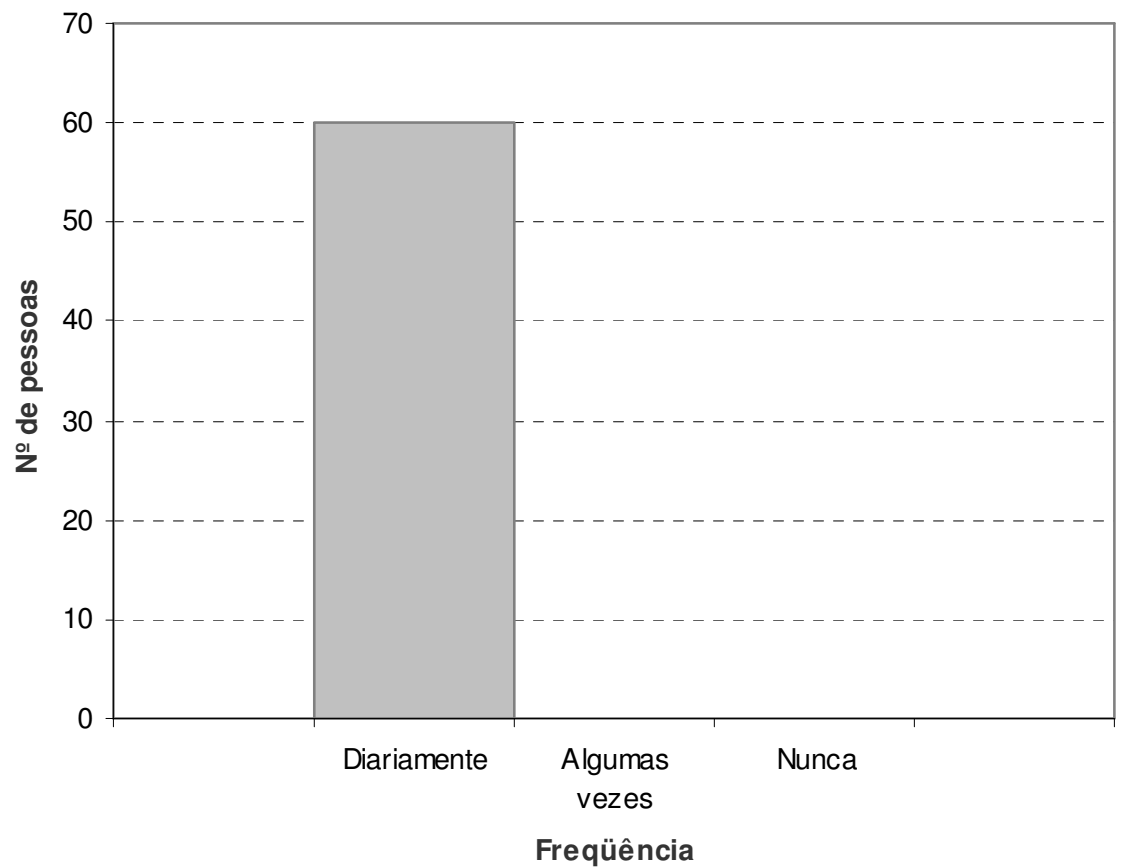

Figura 76 - Uso da iluminação artificial - inverno 


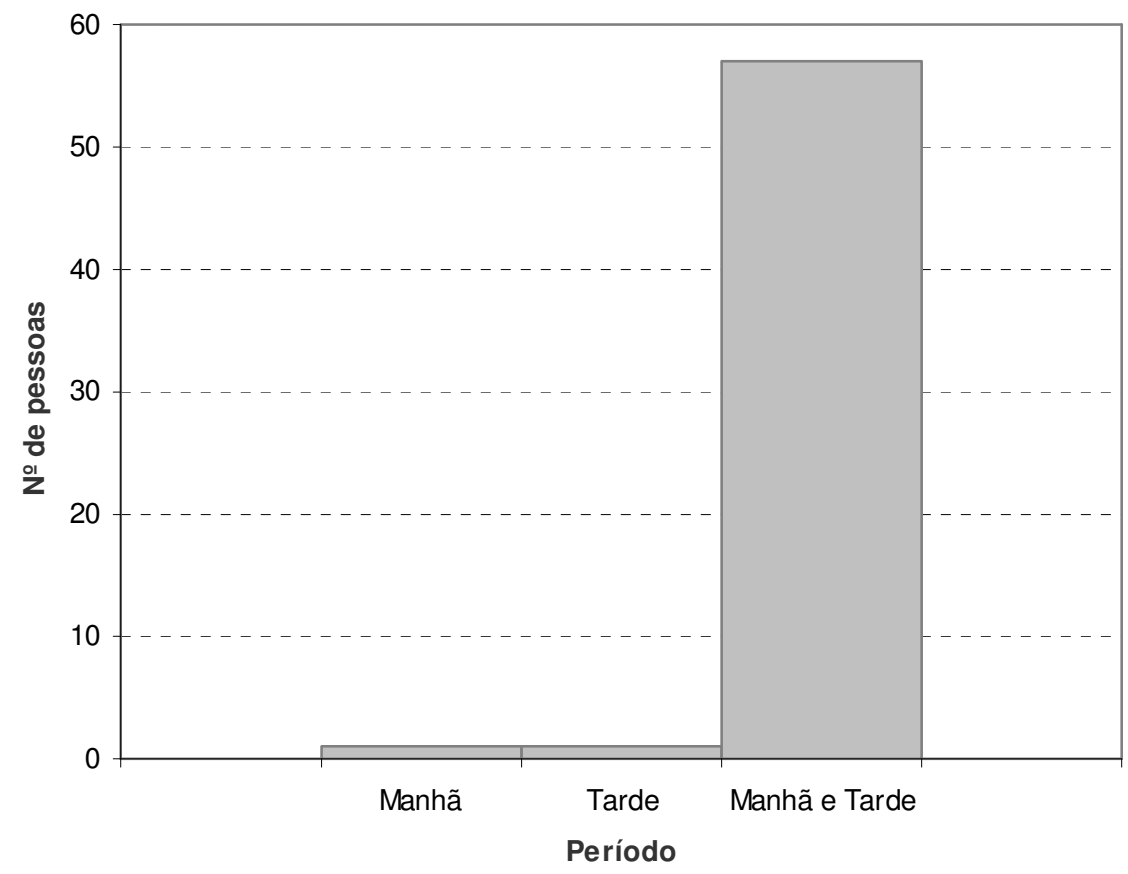

Figura 77 - Uso da iluminação artificial - inverno

A figura 78 representa as respostas referentes à iluminação natural nas mesas de trabalho.

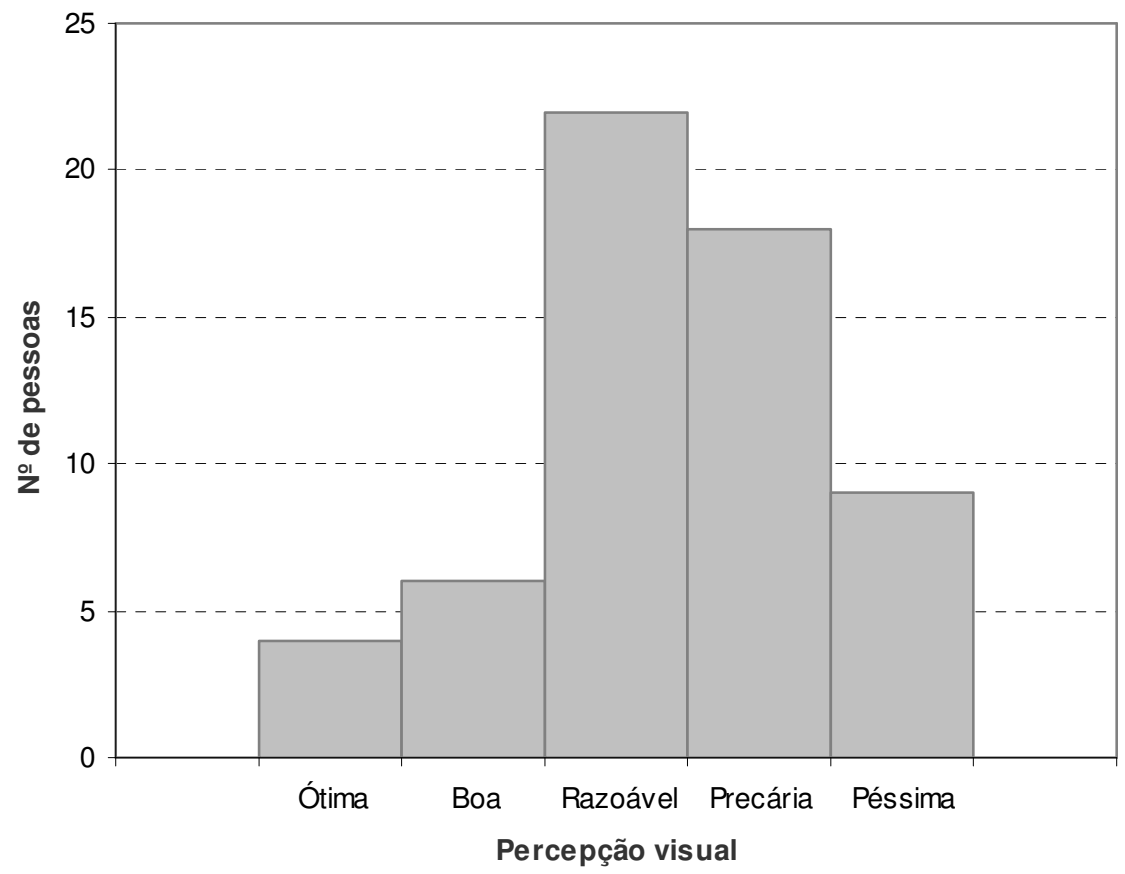

Figura 78 - lluminação natural na mesa de trabalho 
A figura 79 representa as sensações em relação à transparência ocasionada pelas áreas envidraçadas do prédio.

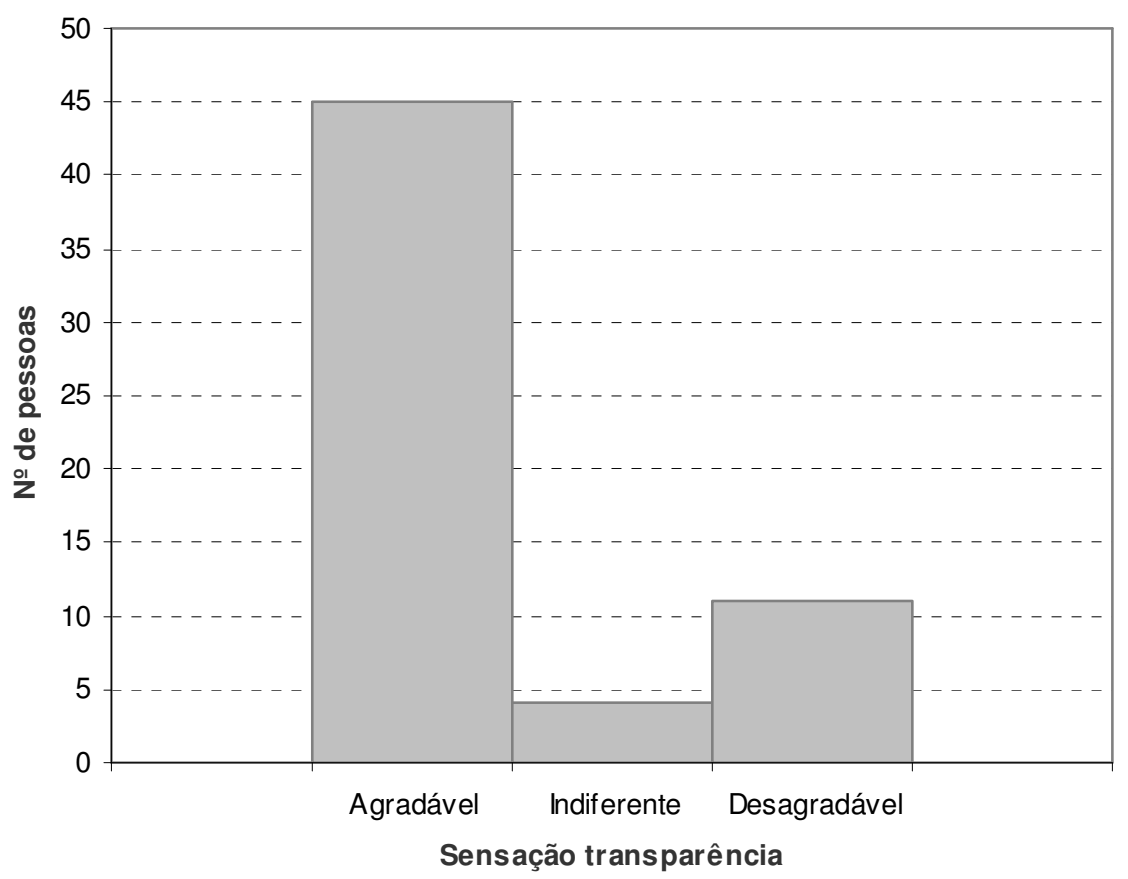

Figura 79 - Sensação quanto à transparência

Em relação aos entrevistados, a divisão entre homens e mulheres é bastante equilibrada, assim como a faixa etária, na qual não há uma faixa de idade predominante.

Quanto às sensações térmicas de verão, a opção mais assinalada foi +2 , que corresponde a quente, sendo que as opções nem quente nem frio, levemente quente e muito quente também foram bastante assinaladas, inclusive com números de votos praticamente iguais.

Quanto às sensações térmicas de inverno, a maioria dos funcionários do Bloco E1 escolheu a opção -2, que corresponde a frio, sendo que as opções levemente frio e muito frio também foram bastante assinaladas, com números de votos praticamente iguais.

$\mathrm{Na}$ perguntas relacionadas ao uso da iluminação artificial, as respostas foram praticamente unânimes quanto à freqüência de uso que é diária e constante durante o dia. 
Em relação à pergunta quanto à iluminação natural na mesa de trabalho, a maioria dos funcionários escolheu as opções razoável e precária, sendo que a opção péssima também obteve um número de votos considerável.

A respeito da sensação quanto à transparência a maioria das pessoas entrevistadas respondeu que essa característica do Bloco E1 é agradável.

\subsection{Níveis de lluminância}

Para a avaliação dos resultados foi seguida a NBR 5413 de abril de 1992 - lluminância de Interiores. Para se obter um valor de referência quanto ao nível de iluminância necessário para o Bloco E1, considerando sua atividade atual de escritório, foram consultadas as tabela 1 e 2 desta norma, as quais encontram-se reproduzidas neste trabalho no capítulo 2.2.4. NBR 5413, tabelas 3 e 4 .

A partir dessas tabelas chegou-se que o valor a ser utilizado como base seria 750 lux. Para essa conclusão foi considerada como tipo de atividade tarefas com requisitos visuais normais de escritório. Foi escolhido o valor médio de iluminância com base em três características da tarefa e do observador: idade (40 a 55 anos), velocidade e precisão (importante), e refletância do fundo da tarefa (superior a $70 \%$ ).

Essa referência foi utilizada para as duas salas estudadas: a Assistência Administrativa e a Ante-sala da Congregação.

\subsubsection{Ambiente: Assistência Administrativa}

Conforme ABNT (2005d) foi realizado o cálculo do número de pontos de medição. Para a sala da Assistência Administrativa o número de pontos é 15. Encontra-se a seguir a planta desta sala com a malha de pontos (figura 80). 


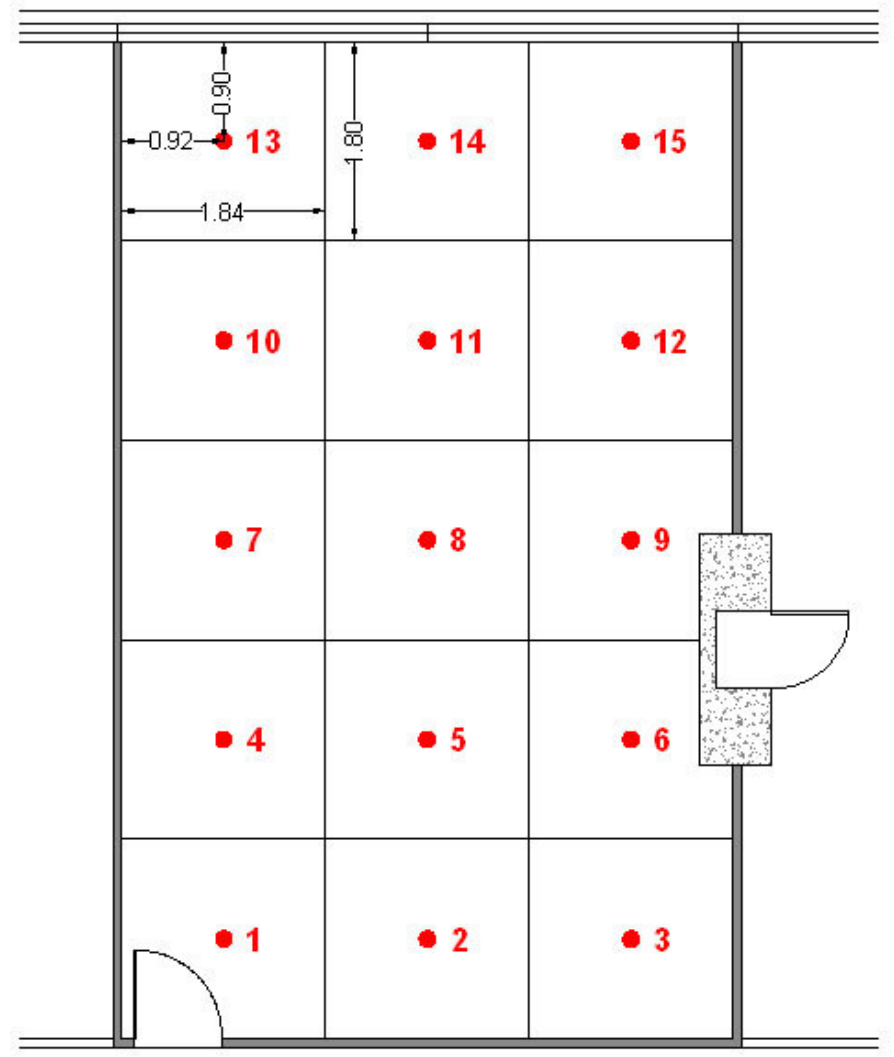

Corredor

\section{$\nabla \mathbf{N}$}

Figura 80 - Planta - Assistência Administrativa - pontos de medição

As medições foram realizadas em dois períodos do ano (janeiro e julho), nos dias 04/01/2008 e 23/07/2007, em três horários diferentes ao longo do dia: $10 \mathrm{~h} 00 \mathrm{~min}, 13 \mathrm{~h} 30 \mathrm{~min}$ e $17 \mathrm{~h} 30 \mathrm{~min}$. A tabela 6 mostra os resultados obtidos no dia 04/01/2008 em cada ponto, para cada um dos três horários. 
Tabela 6 - lluminância por pontos - Assistência Administrativa - 04/01/2008

\begin{tabular}{|c|c|c|c|}
\hline \multirow{2}{*}{ Ponto } & \multicolumn{3}{|c|}{ Iluminância (lux) } \\
\cline { 2 - 4 } & 10 h00min & 13 h30min & 17 h30min \\
\hline 1 & 135 & 250 & 100 \\
\hline 2 & 140 & 236 & 115 \\
\hline 3 & 124 & 220 & 115 \\
\hline 4 & 184 & 318 & 158 \\
\hline 5 & 175 & 335 & 184 \\
\hline 6 & 136 & 277 & 157 \\
\hline 7 & 248 & 472 & 278 \\
\hline 8 & 285 & 517 & 338 \\
\hline 9 & 225 & 419 & 253 \\
\hline 10 & 413 & 800 & 345 \\
\hline 11 & 480 & 856 & 477 \\
\hline 12 & 366 & 566 & 440 \\
\hline 13 & 842 & 2208 & 1059 \\
\hline 14 & 993 & 2190 & 1902 \\
\hline 15 & 758 & 2198 & 1193 \\
\hline
\end{tabular}

A partir desses resultados foram realizados gráficos de contorno (figuras 81, 82 e 83) para a ilustração da distribuição dos níveis de iluminância na sala. Foram criados no Excel com base nos pontos de medição. 


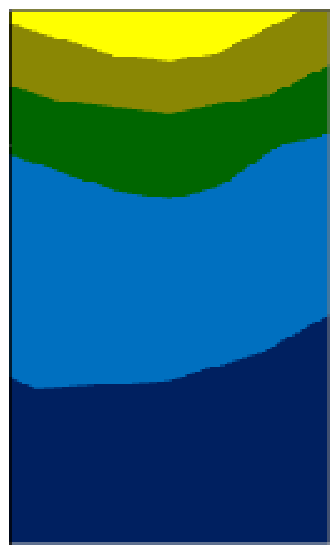

Iluminância (lux)

800-1000

$=600-800$

- 400-600

- $200-400$

- $0-200$

Figura 81 - Curvas isolux - 04/01/2008 - 10h00min

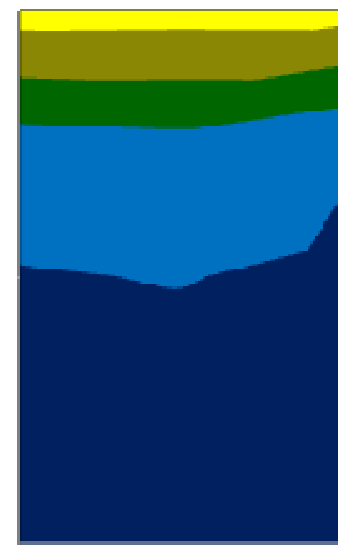

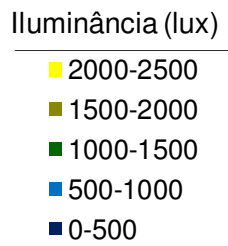

Figura 82 - Curvas isolux - 04/01/2008 - 13h30min

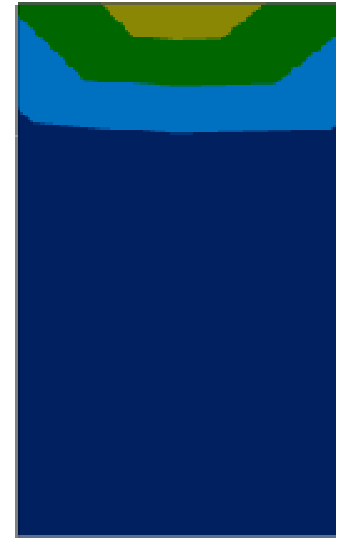

Iluminância (lux)

- 1500-2000

- 1000-1500

- 500-1000

- $0-500$

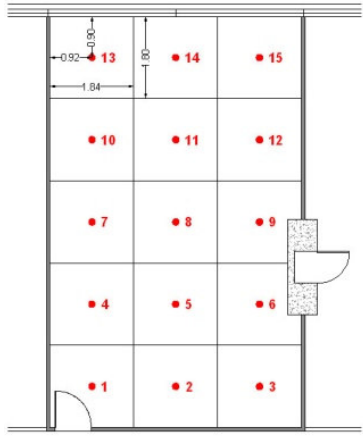

corredor

Figura 83 - Curvas isolux - 04/01/2008 - 17h30min 
A tabela 7 mostra os resultados obtidos no dia 23/07/2007 em cada ponto, para cada um dos três horários.

Tabela 7 - lluminância por pontos - Assistência Administrativa - 23/07/2007

\begin{tabular}{|c|c|c|c|}
\hline \multirow{2}{*}{ Ponto } & \multicolumn{3}{|c|}{ Iluminância (lux) } \\
\cline { 2 - 4 } & $10 \mathrm{~h} 00 \mathrm{~min}$ & $13 \mathrm{~h} 30 \mathrm{~min}$ & $17 \mathrm{~h} 30 \mathrm{~min}$ \\
\hline 1 & 37 & 87 & 11 \\
\hline 2 & 31 & 88 & 10 \\
\hline 3 & 28 & 60 & 9 \\
\hline 4 & 36 & 80 & 8 \\
\hline 5 & 52 & 80 & 11 \\
\hline 6 & 36 & 77 & 6 \\
\hline 7 & 67 & 152 & 15 \\
\hline 8 & 69 & 156 & 18 \\
\hline 9 & 62 & 94 & 13 \\
\hline 10 & 112 & 232 & 40 \\
\hline 11 & 148 & 255 & 36 \\
\hline 12 & 104 & 168 & 28 \\
\hline 13 & 209 & 660 & 172 \\
\hline 14 & 180 & 660 & 170 \\
\hline 15 & 95 & 718 & 214 \\
\hline
\end{tabular}

As figuras 84, 85 e 86 ilustram a distribuição dos níveis de iluminância na sala para o dia 23/07/2007. 


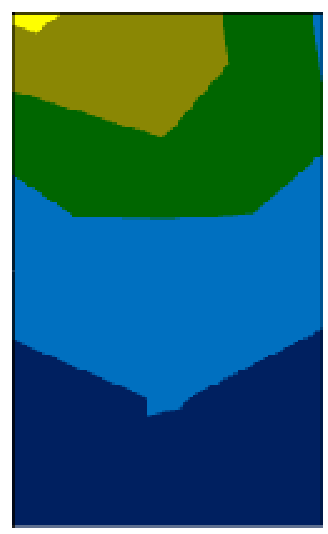

Iluminância (lux)

200-250

-150-200

- 100-150

- 50-100

- $0-50$

Figura 84 - Curvas isolux - 23/07/2007- 10h00min

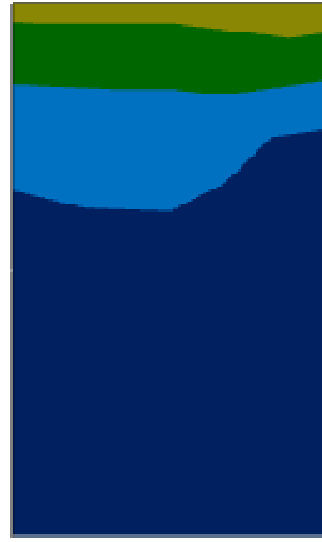

Iluminância (lux)

-600-800

- 400-600

- 200-400

- $0-200$

Figura 85 - Curvas isolux - 23/07/2007 - 13h30min

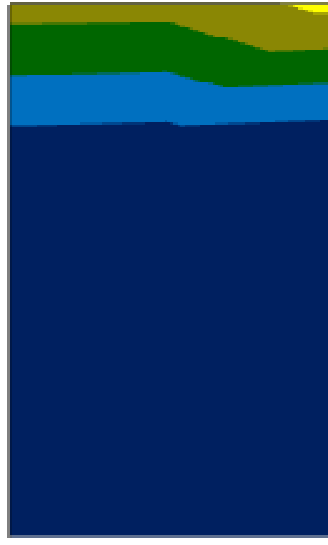

Iluminância (lux)

200-250

- 150-200

- 100-150

- 50-100

- $0-50$

Figura 86 - Curvas isolux - 23/07/2007 - 17h30min

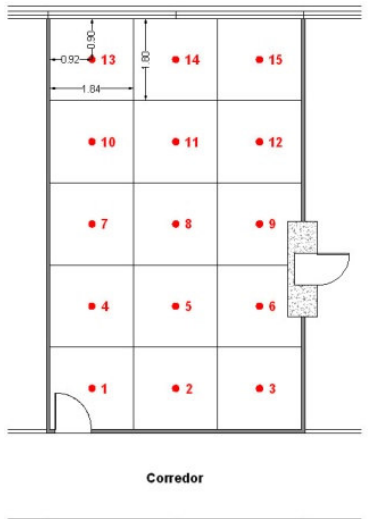


Com base no valor de referência de 750 lux estabelecido, os resultados mostraram para o dia 04/01/2008, período do verão, que no horário das 10h00min é possível atingir esse valor em apenas em pequena porção da sala de trabalho. Na figura 81 essa porção é representada pelas cores amarelo e ocre.

No horário das 13h30min é possível atingir 750 lux em uma parcela maior da sala, aproximadamente metade. Na figura 82 essa porção é representada pelas cores amarelo, ocre, verde e azul claro. Deve-se ressaltar que a área representada pelas cores amarelo, ocre e verde possui níveis de iluminância bem maiores que o recomendado.

No horário das 17h30min o valor de referência é atingido em uma pequena porção. Na figura 83 essa porção é representadas pelas cores ocre, verde e azul claro.

De forma geral os níveis atingiram o recomendado em menos da metade da área da sala, nos três horários medidos. A diferença entre os horários mostrou-se dentro do esperado, já que o melhor resultado foi observado às 13h30min.

Os níveis maiores ficaram concentrados ao longo da fachada sul, sendo menores ao longo da fachada norte, devido à existência de corredores e divisórias, as quais, deve-se enfatizar, foram mudadas em relação àquelas projetadas originalmente.

Com base no valor de referência de 750 lux estabelecido, os resultados mostraram para o dia 23/07/2007, período do inverno, que no horário das 10h00min e das 17h30min esse valor não é atingido em nenhuma porção da sala de trabalho. A iluminância máxima atingida foi 250 lux, em uma pequena parcela, sendo que no horário das 17h30min mais da metade da sala apresentou níveis de iluminância entre 0 e 50 lux.

No horário das 13h30min é possível atingir 750 lux em uma parcela muito pequena da sala, ao longo da fachada sul. Na figura 85 essa parcela é representada pela cor ocre.

De forma geral os níveis não atingiram o recomendado nos três horários medidos. Assim como no verão, os níveis maiores se concentraram ao longo da fachada sul, sendo menores ao longo da fachada norte, devido à existência 
de corredores e divisórias. Em comparação com o período do verão, os níveis de iluminância mostraram-se inferiores.

Para uma comparação com o gráfico para estimativa de níveis de iluminância desenvolvido por Mange (figura 87) foram realizados dois gráficos baseados nos valores obtidos das medições (figuras 88 e 89). Foi considerada apenas a sala da Assistência Administrativa, por se assimilar a situação simulada no gráfico de Mange. Foram feitos gráficos para os dois períodos de medição (verão e inverno), ambos no horário das 13h30min.

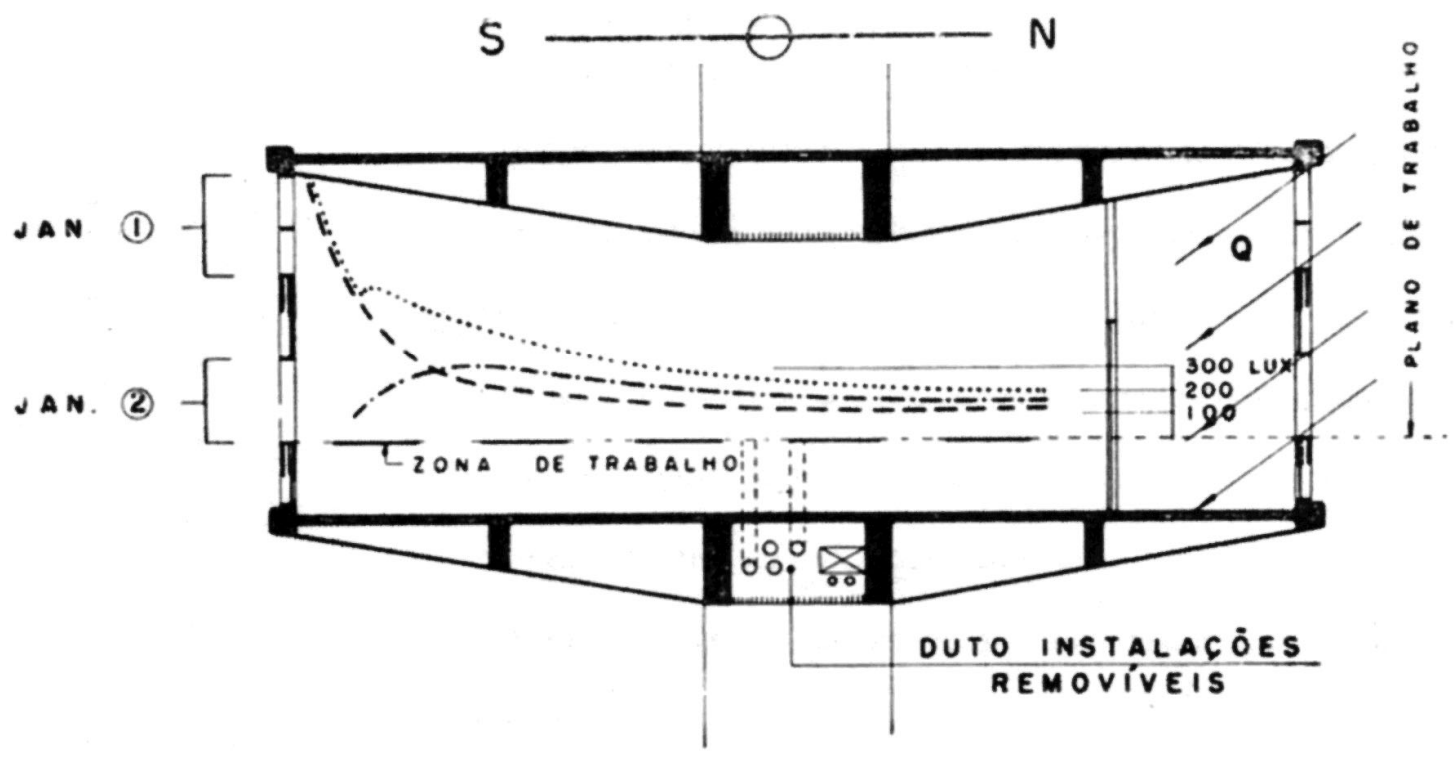

CURVAS DE ACLARAMENTO

CONTRIBUIGÃO DE UMA FACE

-.- - - - - - JANELA (1)

- - - - - JANELA (2)

$S O$. A

Figura 87 - Gráfico para iluminação desenvolvido por Mange Fonte - Mange et al. (1959) 


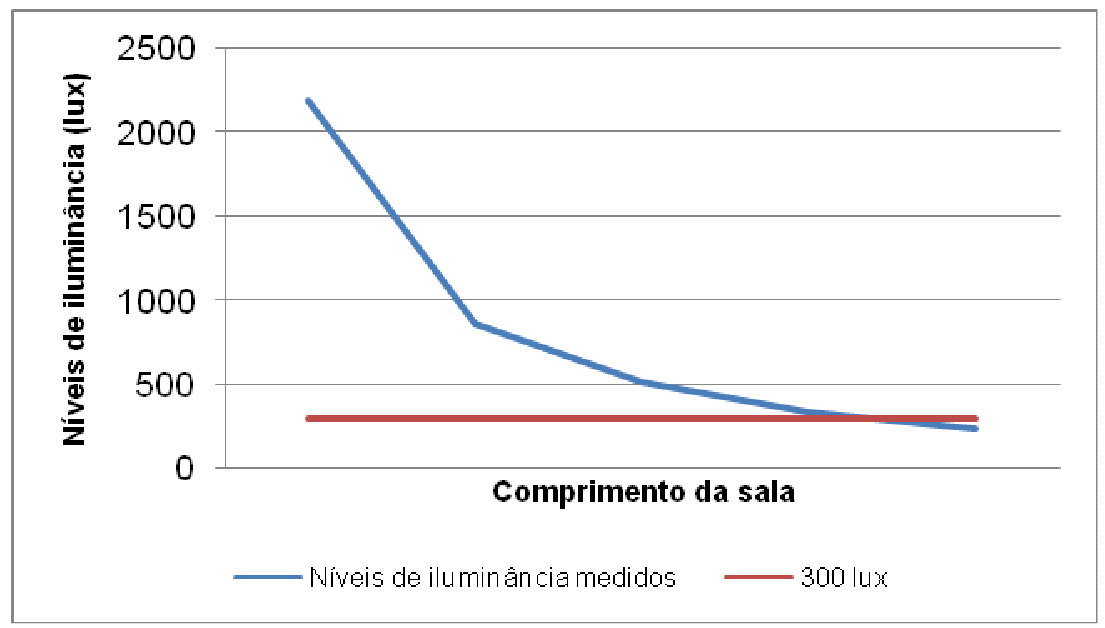

Figura 88 - Curvas de aclaramento - Verão - 13h30min

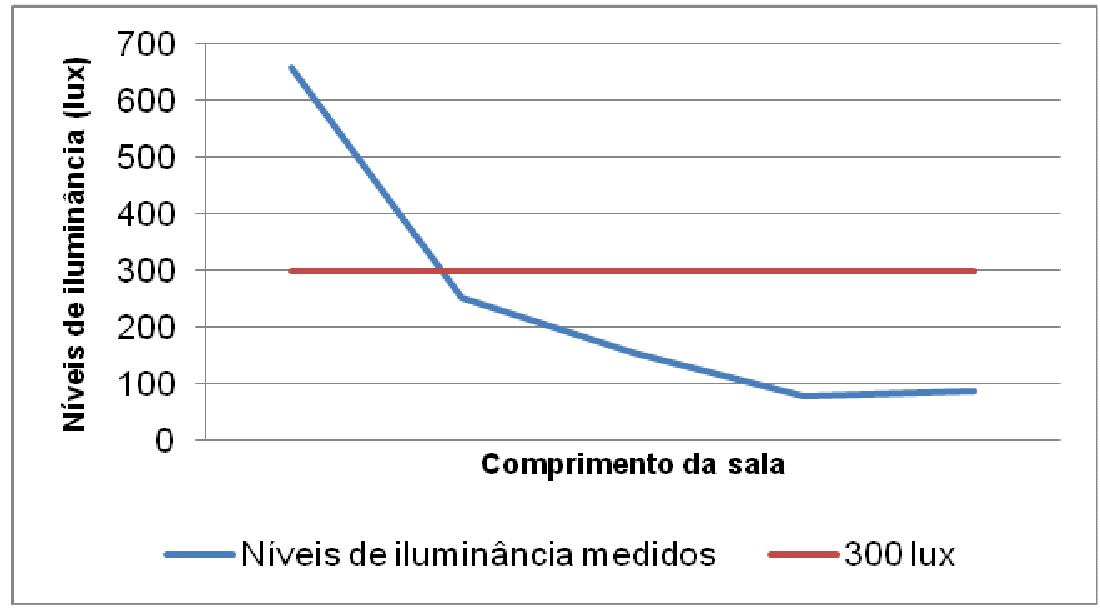

Figura 89 - Curvas de aclaramento - Inverno - 13h30min

Pode-se notar que a distribuição dos níveis de iluminância medidos na sala de trabalho da assistência administrativa possui comportamento similar ao das curvas de iluminância calculadas por Mange, de forma geral possuem intensidade maior nas regiões próximas à fachada sul, decrescendo em direção à fachada norte, onde há divisórias para eliminar a iluminação direta nas áreas de trabalho.

No período do verão, a curva de aclaramento resultante dos níveis de iluminância medidos in loco ficou muito similar a desenhada por Mange, tendo valores um pouco superiores. Já no período do inverno, a curva resultante também teve comportamento similar, porém com valores um pouco inferiores em relação ao gráfico de Mange. 
Em seu desenho Mange estabelece como referência os valores de 100, 200 e 300 lux. Deve-se acrescentar que não é conhecida a referência de Mange para estipular esses valores. Porém, para análise de iluminância nas áreas de trabalho desta pesquisa foi considerado o valor de 750 lux com base na ABNT (1992), devido à situação de uso atual das salas, as são utilizadas como escritórios.

\subsubsection{Ambiente: Ante-sala da Congregação}

Conforme ABNT (2005d) foi realizado o cálculo do número de pontos de medição. Para a Ante-sala da Congregação o número de pontos é 15. Encontra-se a seguir a planta desta sala com a malha de pontos (figura 90).

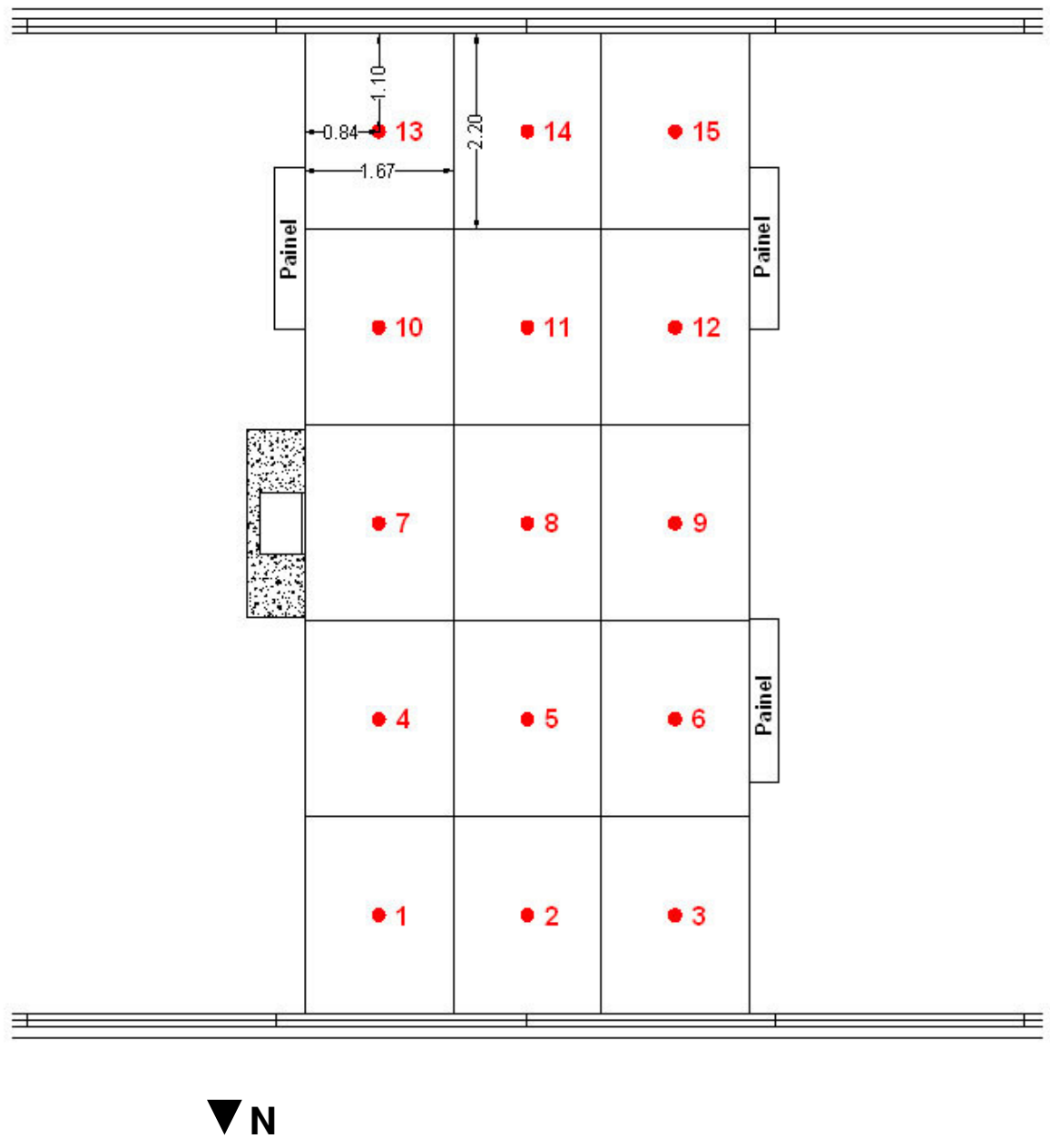

Figura 90 - Planta - Ante-sala da Congregação - pontos de medição 
A tabela 8 mostra os resultados obtidos no dia 04/01/2008 em cada ponto, para cada um dos três horários.

Tabela 8 - lluminância por pontos - Ante-sala da Congregação - 04/01/2008

\begin{tabular}{|c|c|c|c|}
\hline \multirow{2}{*}{ Ponto } & \multicolumn{3}{|c|}{ Iluminância (Iux) } \\
\cline { 2 - 4 } & 11 h00min & 14 h30min & 18 h00min \\
\hline 1 & 612 & 1182 & 195 \\
\hline 2 & 709 & 1583 & 240 \\
\hline 3 & 833 & 1660 & 348 \\
\hline 4 & 465 & 800 & 113 \\
\hline 5 & 505 & 855 & 138 \\
\hline 6 & 472 & 830 & 150 \\
\hline 7 & 469 & 848 & 287 \\
\hline 8 & 443 & 792 & 300 \\
\hline 9 & 342 & 614 & 109 \\
\hline 10 & 661 & 1013 & 180 \\
\hline 11 & 637 & 1009 & 226 \\
\hline 12 & 573 & 971 & 211 \\
\hline 13 & 1180 & 2205 & 390 \\
\hline 14 & 1093 & 2194 & 380 \\
\hline 15 & 1275 & 2223 & 505 \\
\hline
\end{tabular}

As figuras 91, 92 e 93 ilustram a distribuição dos níveis de iluminância na sala para o dia 04/01/2008. 


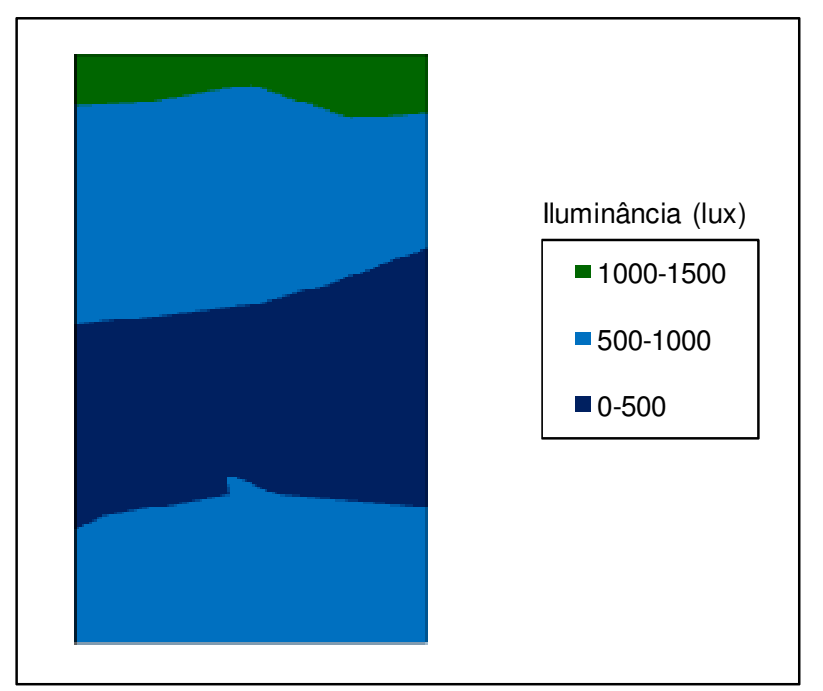

$\boldsymbol{\nabla N}$

Figura 91 - Curvas isolux - 04/01/2008 - 11h00min

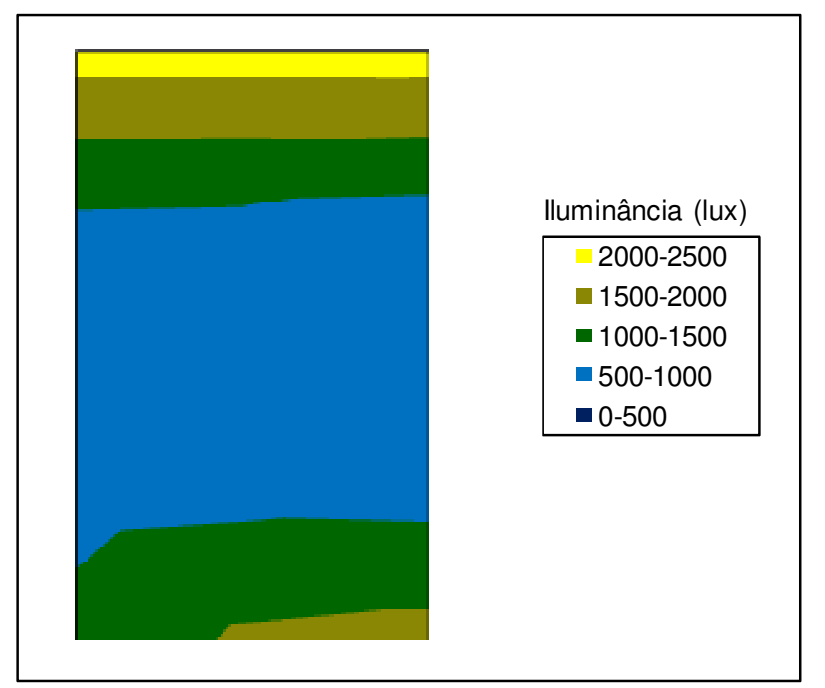

Figura 92 - Curvas isolux - 04/01/2008 - 14h30min

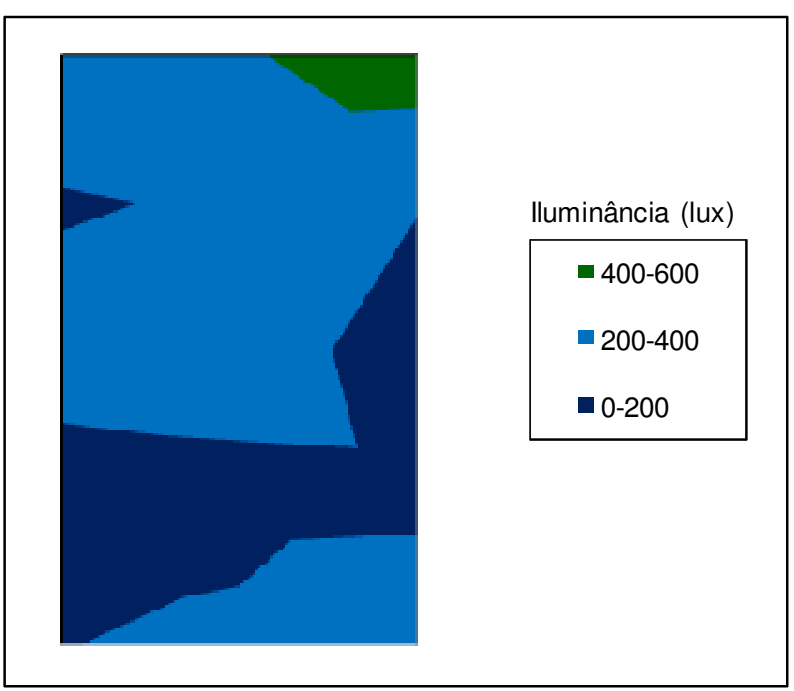

Figura 93 - Curvas isolux - 04/01/2008 - 18h00min

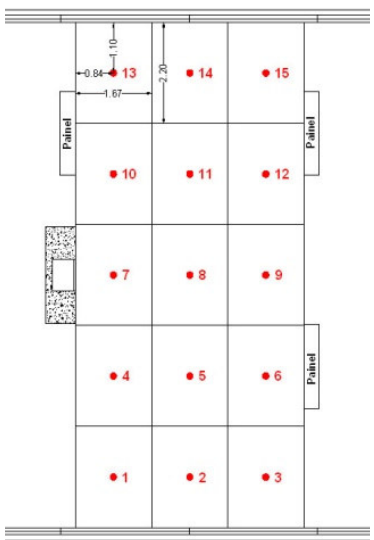


A tabela 9 mostra os resultados obtidos no dia 23/07/2007 em cada ponto, para cada um dos três horários.

Tabela 9 - lluminância por pontos - Ante-sala da Congregação - 23/07/2007

\begin{tabular}{|c|c|c|c|}
\hline \multirow{2}{*}{ Ponto } & \multicolumn{3}{|c|}{ lluminância (lux) } \\
\cline { 2 - 4 } & 11 h00min & $14 \mathrm{~h} 30 \mathrm{~min}$ & $18 \mathrm{~h} 00 \mathrm{~min}$ \\
\hline 1 & 311 & 587 & 107 \\
\hline 2 & 485 & 675 & 113 \\
\hline 3 & 538 & 662 & 105 \\
\hline 4 & 159 & 285 & 52 \\
\hline 5 & 184 & 312 & 57 \\
\hline 6 & 203 & 320 & 56 \\
\hline 7 & 215 & 182 & 111 \\
\hline 8 & 185 & 187 & 85 \\
\hline 9 & 144 & 162 & 60 \\
\hline 10 & 300 & 247 & 116 \\
\hline 11 & 228 & 282 & 128 \\
\hline 12 & 220 & 260 & 110 \\
\hline 13 & 647 & 475 & 288 \\
\hline 14 & 612 & 585 & 233 \\
\hline 15 & 675 & 662 & 262 \\
\hline
\end{tabular}

As figuras 94, 95 e 96 ilustram a distribuição dos níveis de iluminância na sala para o dia 23/07/2007. 


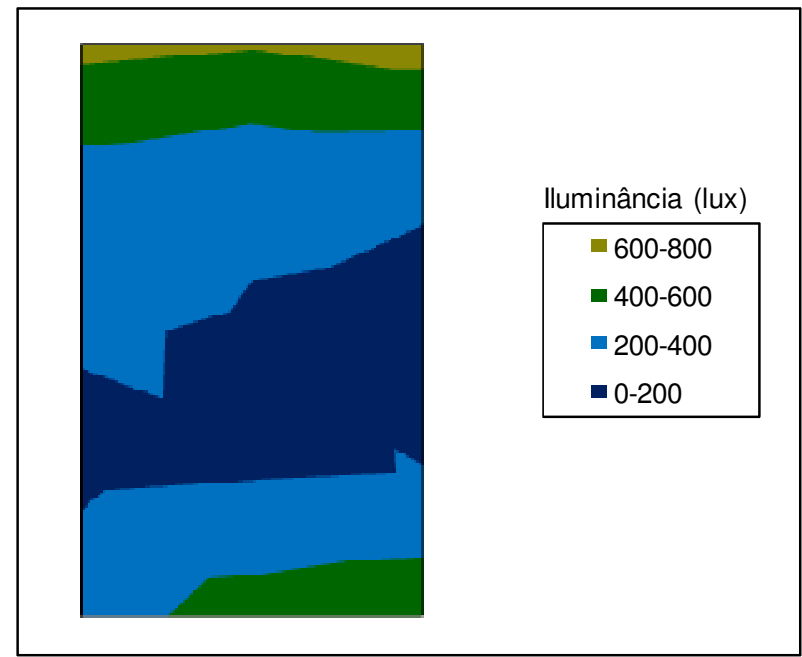

$\nabla N$

Figura 94 - Curvas isolux - 23/07/2007 - 11h00min

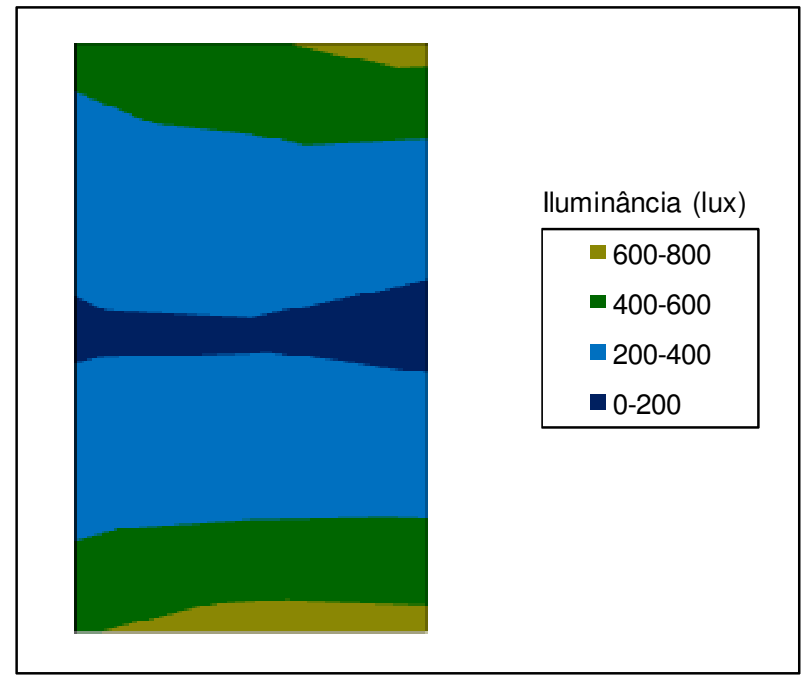

Figura 95 - Curvas isolux - 23/07/2007 - 14h30min

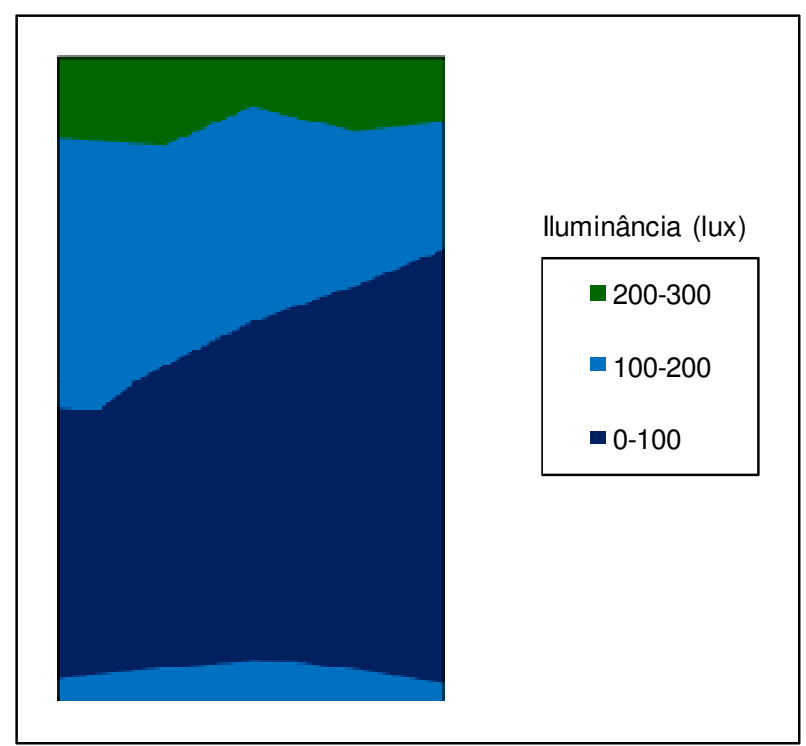

Figura 96 - Curvas isolux - 23/07/2007 - 18h00min 
Com base no valor de referência de 750 lux estabelecido, os resultados mostraram para o 04/01/2008, período do verão, que no horário das 11h00min esse valor é atingido em parcela significativa da sala de trabalho.

No horário das $14 \mathrm{~h} 30 \mathrm{~min}$ é possível atingir 750 lux praticamente em toda a sala, mostrando-se um resultado muito satisfatório.

No horário das 18h00min não é possível atingir 750 lux em nenhuma região da sala.

Os níveis de iluminância mostraram-se mais elevados ao longo da fachada sul, sendo possível citar como uma das causas a grande quantidade de árvores presentes ao longo da fachada norte.

Com base no valor de referência de 750 lux estabelecido, os resultados mostraram para o 23/07/2007, período do inverno, que no horário das $11 \mathrm{~h} 00 \mathrm{~min}$ e das $14 \mathrm{~h} 30 \mathrm{~min}$ esse valor é atingido em parcelas muito pequenas da sala de trabalho, sendo ilustradas nas figuras 94 e 95 pela cor ocre.

No horário das 18h00min não é possível atingir 750 lux em nenhuma região da sala.

\subsection{Variáveis ambientais}

Foram feitas, para cada sala, medições das variáveis ambientais em quatro períodos, de quatro dias cada um. Os gráficos apresentados a seguir são referentes a um dia de cada um desses períodos, exceto para a Ante-sala da Congregação, no período 1, em que foram considerados dois dias, tendo como diferencial a abertura das janelas. Também são apresentadas neste capítulo tabelas (tabelas 12 a 20) com os resultados de PMV e PPD obtidos com base nas medições e calculados com auxílio do software desenvolvido pela Universidade Federal de Santa Catarina, o qual acompanha o Confortímetro SENSU.

\section{- Período 1}

Assistência Administrativa: 14 a 17 de novembro de 2006 (figura 98).

Ante-sala da Congregação: 21 a 24 de novembro de 2006 (figuras 103 e 104). 
Índice de vestimenta: 0.49 clo

Atividade: $65 \mathrm{~W} / \mathrm{m}^{2}$

- Período 2

Assistência Administrativa: 05 a 08 de março de 2007 (figura 99).

Ante-sala da Congregação: 12 a 15 de março de 2007 (figura 105).

Índice de vestimenta: 0.49 clo

Atividade: $65 \mathrm{~W} / \mathrm{m}^{2}$

- Período 3

Assistência Administrativa: 11 a 14 de junho de 2007 (figura 100).

Ante-sala da Congregação: 31 de maio a 03 de junho de 2007 (figura 106).

Índice de vestimenta: 0.86 clo

Atividade: $65 \mathrm{~W} / \mathrm{m}^{2}$

- Período 4

Assistência Administrativa: 26 a 29 de junho de 2007 (figura 101).

Ante-sala da Congregação: 05 a 08 de julho de 2007 (figura 107).

Índice de vestimenta: 0.86 clo

Atividade: $65 \mathrm{~W} / \mathrm{m}^{2}$

Deve-se destacar que para a avaliação do PMV e PPD foi utilizada a escala de sensação térmica de sete pontos, conforme ISO (2005).

+3 Muito quente

+2 Quente

+1 Levemente quente

0 Neutro

-1 Levemente frio

-2 Frio

-3 Muito frio

Para a aproximação de valores foi utilizado o seguinte critério de arredondamento: valores entre -0.51 e +0.50 foram considerados como neutro, 
valores entre +0.51 e +1.50 foram considerados como levemente quente e assim sucessivamente.

\subsubsection{Ambiente: Assistência Administrativa}

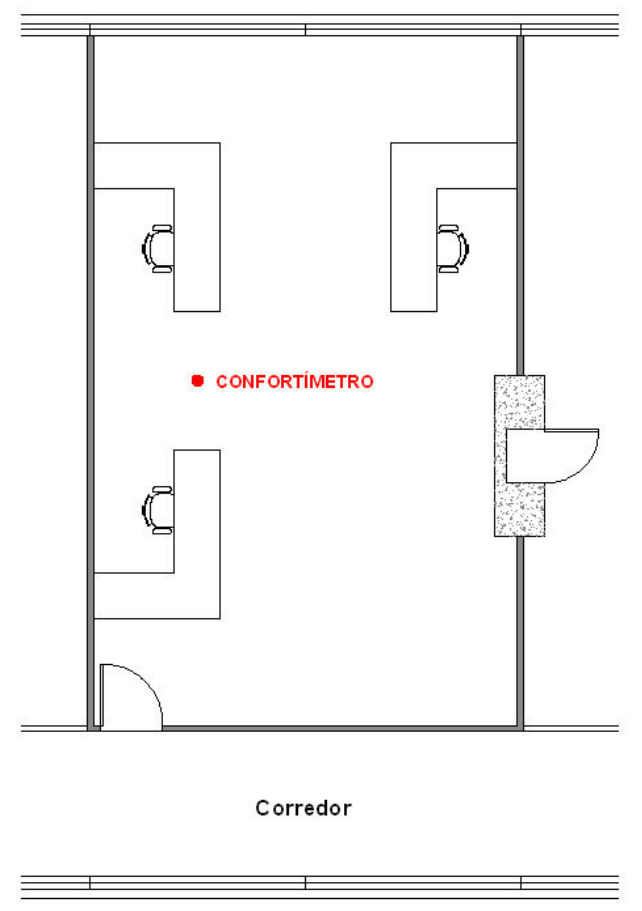

Figura 97 - Planta - Assistência Administrativa - localização do confortímetro

Resultados do período 1: Dia: 17/11/2006

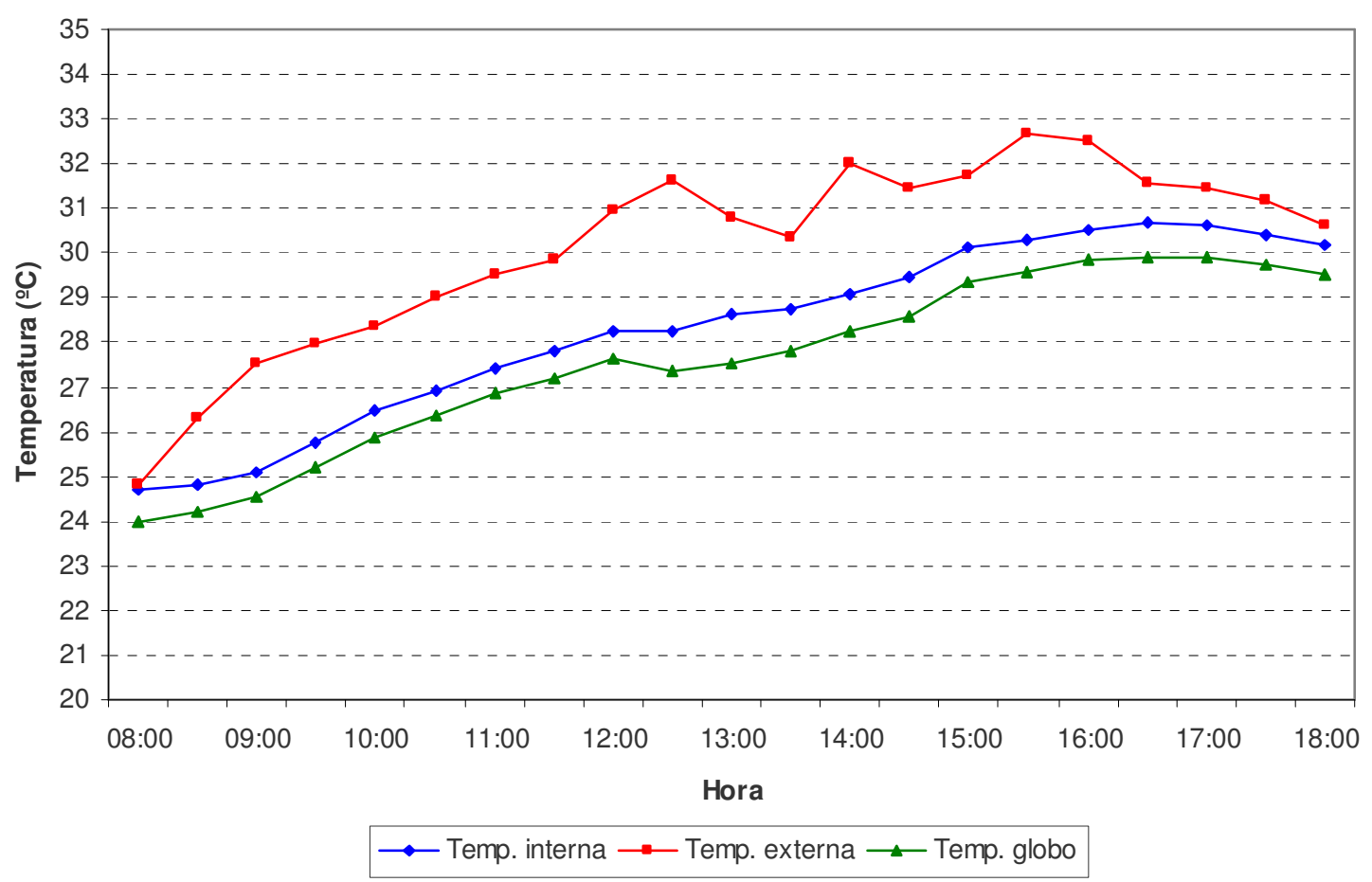

Figura 98 - Temperatura do ar - 17/11/2006 
De modo geral, a temperatura interna para o dia 17/11/2006 foi se elevando ao longo do dia, porém mantendo-se sempre abaixo da temperatura externa. A média das temperaturas externas foi de $30,11^{\circ} \mathrm{C}$, enquanto a média das internas foi de $28,30^{\circ} \mathrm{C}$, constatando-se uma diferença de $1,81^{\circ} \mathrm{C}$. A temperatura interna máxima atingida foi de $30,71^{\circ} \mathrm{C}$ às $16 \mathrm{~h} 30 \mathrm{~min}$.

Tabela 10 - PMV e PPD - 17/11/2
\begin{tabular}{|c|c|c|}
\hline HORA & PMV & PPD \\
\hline $8: 00$ & -0.79 & 18.05 \\
\hline $8: 30$ & -0.78 & 17.68 \\
\hline $9: 00$ & -0.80 & 18.40 \\
\hline $9: 30$ & -0.49 & 10.12 \\
\hline $10: 00$ & -0.26 & 6.39 \\
\hline $10: 30$ & -0.15 & 5.44 \\
\hline $11: 00$ & 0.19 & 5.77 \\
\hline $11: 30$ & 0.23 & 6.12 \\
\hline $12: 00$ & 0.45 & 9.19 \\
\hline $12: 30$ & 0.72 & 15.83 \\
\hline $13: 00$ & 0.81 & 18.98 \\
\hline $13: 30$ & 0.86 & 20.49 \\
\hline $14: 00$ & 0.79 & 18.17 \\
\hline $14: 30$ & 0.87 & 21.00 \\
\hline $15: 00$ & 1.23 & 36.64 \\
\hline $15: 30$ & 1.26 & 38.30 \\
\hline $16: 00$ & 1.37 & 43.99 \\
\hline $16: 30$ & 1.42 & 46.72 \\
\hline $17: 00$ & 1.34 & 42.57 \\
\hline $17: 30$ & 1.32 & 41.31 \\
\hline $18: 00$ & 1.18 & 34.23 \\
\hline
\end{tabular}

Os valores para o índice PMV correspondentes ao dia 17/11/2006 variaram desde -0.80 , que corresponde a levemente frio a 1.42 , que corresponde a levemente quente. Os valores correspondentes a levemente frio se concentraram na primeira hora da manhã, sendo que na maior parte da manhã o PMV foi próximo a 0 , que corresponde a neutro. A partir das $12 \mathrm{~h} 30 \mathrm{~min}$ os valores corresponderam a levemente quente, permanecendo assim até às $18 \mathrm{~h} 00 \mathrm{~min}$. Pode-se dizer que durante esse dia, no período de atividades do edifício, na maior parte do tempo o PMV foi próximo a 1, ou seja, levemente quente. 
Resultados do período 2: Dia: 07/03/2007

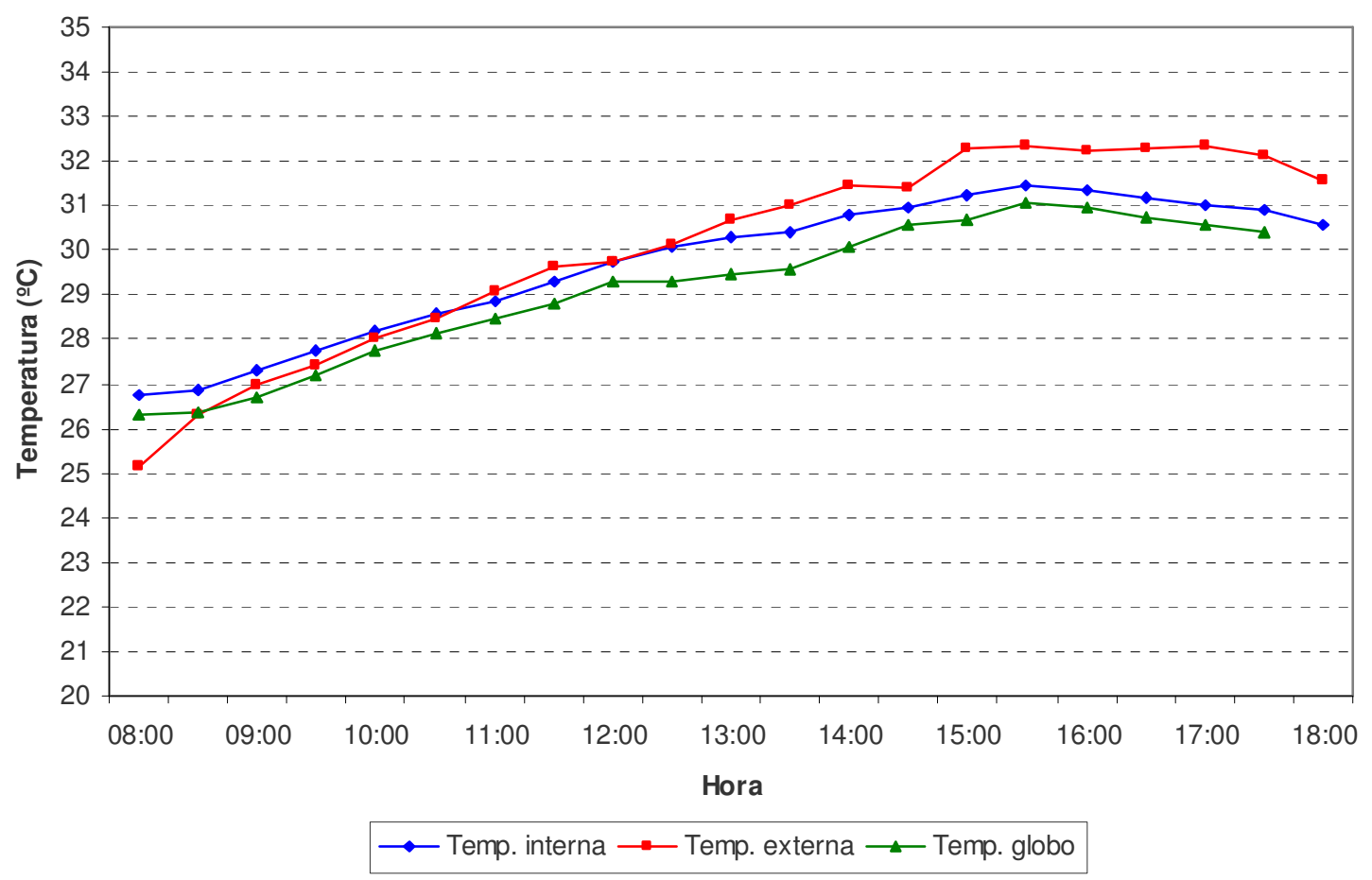

Figura 99 - Temperatura do ar - 07/03/2007

De modo geral, a temperatura interna para o dia 07/03/2007 foi se elevando ao longo do dia, mantendo-se bastante próxima da temperatura externa. A média das temperaturas externas foi de $30,03^{\circ} \mathrm{C}$, enquanto a média das internas foi de $29,70^{\circ} \mathrm{C}$, constatando-se uma diferença de $0,33^{\circ} \mathrm{C}$. A temperatura interna máxima atingida foi de $31,43^{\circ} \mathrm{C}$ às $15 \mathrm{~h} 30 \mathrm{~min}$. 
Tabela 11 - PMV e PPD - 07/03/2007

\begin{tabular}{|c|c|c|}
\hline HORA & PMV & PPD \\
\hline $8: 00$ & 0.10 & 5.22 \\
\hline $8: 30$ & 0.01 & 5.00 \\
\hline $9: 00$ & 0.20 & 5.82 \\
\hline $9: 30$ & 0.32 & 7.13 \\
\hline $10: 00$ & 0.44 & 9.07 \\
\hline $10: 30$ & 0.59 & 12.19 \\
\hline $11: 00$ & 0.67 & 14.57 \\
\hline $11: 30$ & 0.92 & 23.04 \\
\hline $12: 00$ & 1.04 & 27.97 \\
\hline $12: 30$ & 1.36 & 43.37 \\
\hline $13: 00$ & 1.40 & 45.71 \\
\hline $13: 30$ & 1.46 & 48.99 \\
\hline $14: 00$ & 1.49 & 50.18 \\
\hline $14: 30$ & 1.52 & 52.23 \\
\hline $15: 00$ & 1.67 & 60.29 \\
\hline $15: 30$ & 1.71 & 62.50 \\
\hline $16: 00$ & 1.70 & 61.77 \\
\hline $16: 30$ & 1.61 & 56.87 \\
\hline $17: 00$ & 1.55 & 53.61 \\
\hline $17: 30$ & 1.47 & 49.08 \\
\hline $18: 00$ & 1.47 & 49.13 \\
\hline
\end{tabular}

Os valores para o índice PMV correspondentes ao dia 07/03/2007 variaram desde 0.01 , que corresponde a neutro a 1.71, que corresponde a quente. Os valores correspondentes a neutro se concentraram nas primeiras horas da manhã. A partir das 10h30min os valores corresponderam a levemente quente, permanecendo assim até às 14h00min. A partir desse horário até às 17h00min o PMV fica em quente, após esse período retorna a levemente quente. Pode-se dizer que durante esse dia, no período de atividades do edifício, na maior parte do tempo o PMV foi próximo a 1, ou seja, levemente quente. 
Resultados do período 3: Dia: 11/06/2007

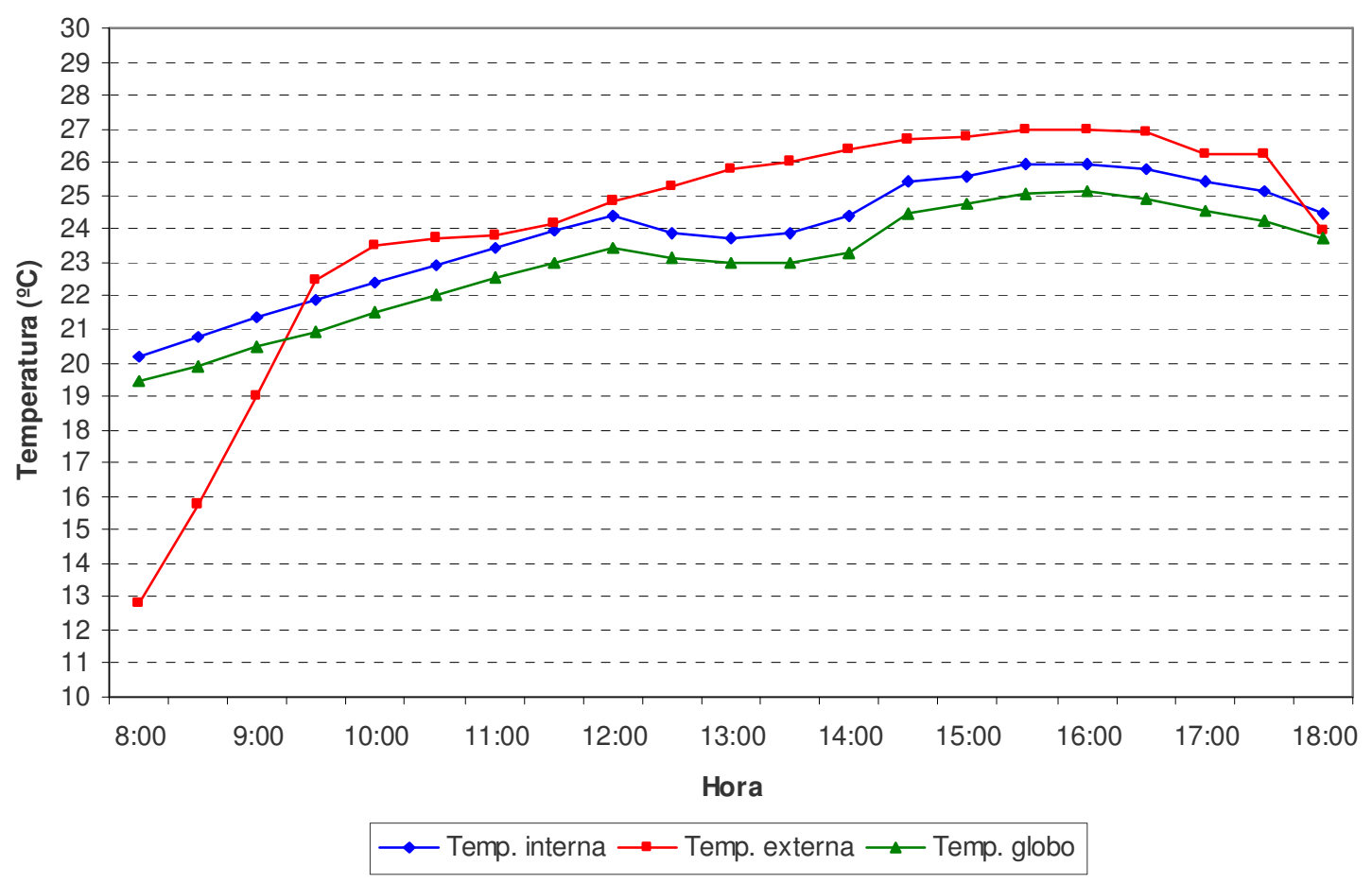

Figura 100 - Temperatura do ar - 11/06/2007

De modo geral, a temperatura interna para o dia 11/06/2007 foi se elevando ao longo do dia, mantendo-se abaixo da temperatura externa, exceto na primeira hora da manhã, quando a temperatura interna está muito acima da externa. A média das temperaturas externas foi de $24,01^{\circ} \mathrm{C}$, enquanto a média das internas foi de $23,85^{\circ} \mathrm{C}$, constatando-se uma diferença de $0,16^{\circ} \mathrm{C}$. A temperatura interna máxima atingida foi de $25,95^{\circ} \mathrm{C}$ às $15 \mathrm{~h} 30 \mathrm{~min}$ e a mínima $20,19^{\circ} \mathrm{C}$ às $08 \mathrm{~h} 00 \mathrm{~min}$. 
Tabela 12 - PMV e PPD - 11/06/2007

\begin{tabular}{|c|c|c|}
\hline HORA & PMV & PPD \\
\hline $8: 00$ & -0.91 & 22.44 \\
\hline $8: 30$ & -0.74 & 16.38 \\
\hline $9: 00$ & -0.54 & 11.16 \\
\hline $9: 30$ & -0.54 & 11.13 \\
\hline $10: 00$ & -0.26 & 6.38 \\
\hline $10: 30$ & -0.19 & 5.74 \\
\hline $11: 00$ & -0.09 & 5.17 \\
\hline $11: 30$ & 0.06 & 5.08 \\
\hline $12: 00$ & 0.13 & 5.36 \\
\hline $12: 30$ & 0.08 & 5.14 \\
\hline $13: 00$ & 0.02 & 5.01 \\
\hline $13: 30$ & 0.11 & 5.24 \\
\hline $14: 00$ & 0.08 & 5.14 \\
\hline $14: 30$ & 0.37 & 7.90 \\
\hline $15: 00$ & 0.47 & 9.60 \\
\hline $15: 30$ & 0.49 & 10.06 \\
\hline $16: 00$ & 0.53 & 10.89 \\
\hline $16: 30$ & 0.49 & 9.92 \\
\hline $17: 00$ & 0.40 & 8.30 \\
\hline $17: 30$ & 0.37 & 7.86 \\
\hline $18: 00$ & 0.23 & 6.08 \\
\hline
\end{tabular}

Os valores para o índice PMV correspondentes ao dia 11/06/2007 variaram desde -0.91, que corresponde a levemente frio a 0.53 , que corresponde a levemente quente. Os valores correspondentes a neutro foram obtidos na maior parte do dia. Pode-se dizer que durante esse dia, no período de atividades do edifício, na maior parte do tempo o PMV foi próximo a 0 , ou seja, neutro. 
Resultados do período 4: Dia: 28/06/2007

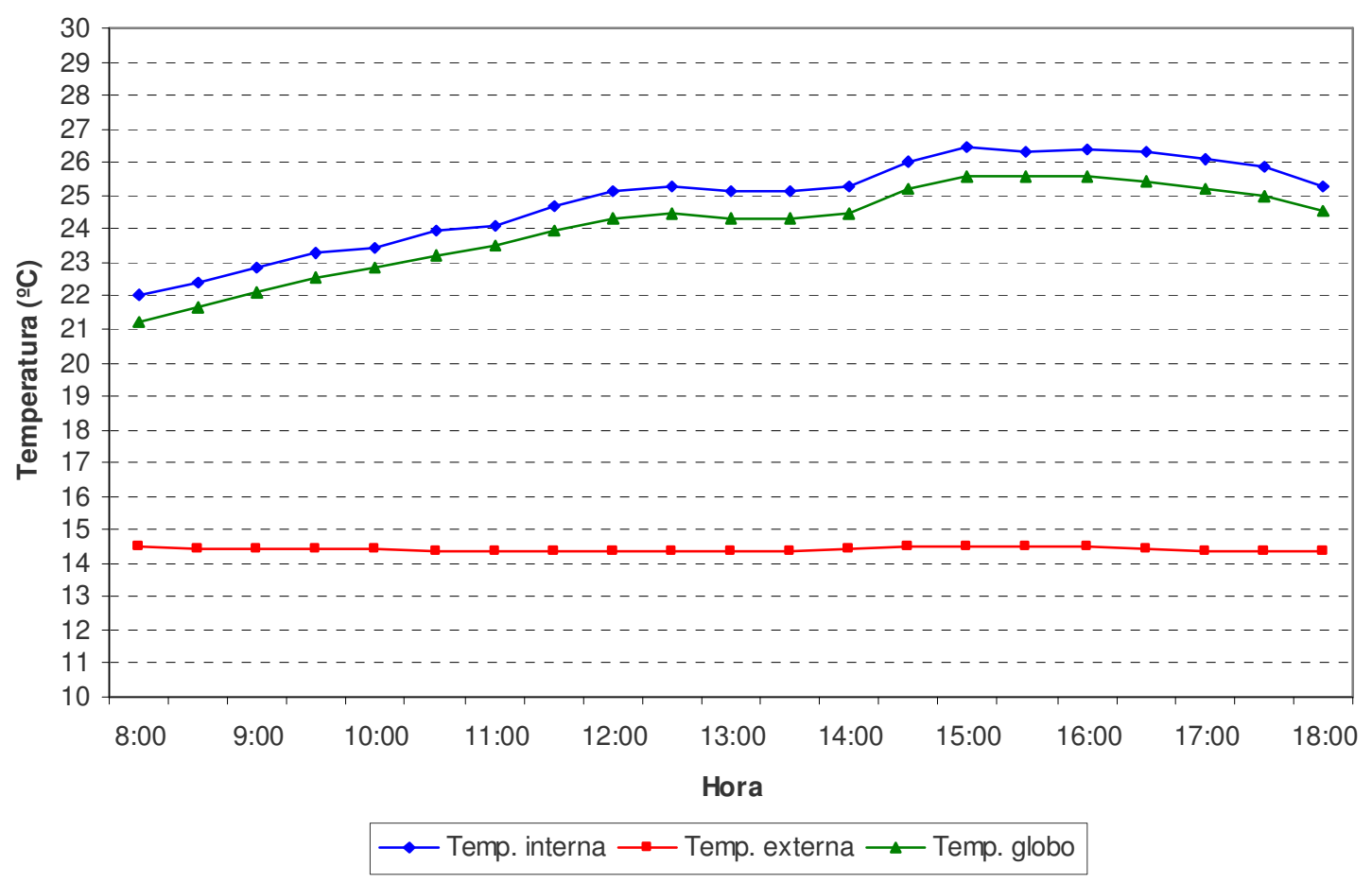

Figura 101 - Temperatura do ar - 28/06/2007

De modo geral, a temperatura interna para o dia 28/06/2007 manteve-se muito acima da temperatura externa. A média das temperaturas externas foi de $14,41^{\circ} \mathrm{C}$, enquanto a média das internas foi de $24,83^{\circ} \mathrm{C}$, constatando-se uma diferença de $10,42^{\circ} \mathrm{C}$. A temperatura interna máxima atingida foi de $26,43^{\circ} \mathrm{C}$ às 15 h00min e a mínima $22,03^{\circ} \mathrm{C}$ às 08 h00min. 
Tabela 13 - PMV e PPD - 28/06/2007

\begin{tabular}{|c|c|c|}
\hline HORA & PMV & PPD \\
\hline $8: 00$ & -0.34 & 7.43 \\
\hline $8: 30$ & -0.30 & 6.87 \\
\hline $9: 00$ & -0.25 & 6.33 \\
\hline $9: 30$ & -0.15 & 5.46 \\
\hline $10: 00$ & -0.28 & 6.58 \\
\hline $10: 30$ & -0.07 & 5.10 \\
\hline $11: 00$ & -0.19 & 5.76 \\
\hline $11: 30$ & 0.06 & 5.08 \\
\hline $12: 00$ & 0.19 & 5.76 \\
\hline $12: 30$ & 0.30 & 6.89 \\
\hline $13: 00$ & 0.36 & 7.76 \\
\hline $13: 30$ & 0.38 & 8.00 \\
\hline $14: 00$ & 0.43 & 8.82 \\
\hline $14: 30$ & 0.49 & 10.10 \\
\hline $15: 00$ & 0.64 & 13.54 \\
\hline $15: 30$ & 0.66 & 14.13 \\
\hline $16: 00$ & 0.64 & 13.53 \\
\hline $16: 30$ & 0.57 & 11.78 \\
\hline $17: 00$ & 0.49 & 10.11 \\
\hline $17: 30$ & 0.44 & 9.13 \\
\hline $18: 00$ & 0.29 & 6.74 \\
\hline
\end{tabular}

Os valores para o índice PMV correspondentes ao dia 28/06/2007 variaram desde -0.34 , que corresponde a neutro a 0.66 , que corresponde a levemente quente. Os valores correspondentes a neutro foram obtidos desde 0 início do expediente até às 14h30min. A partir das 15h00min os valores corresponderam a levemente quente, permanecendo assim até às $16 \mathrm{~h} 30 \mathrm{~min}$. $A$ partir desse horário o PMV retorna a neutro. Pode-se dizer que durante esse dia, no período de atividades do edifício, na maior parte do tempo o PMV foi de 0 , ou seja, neutro. 


\subsubsection{Ambiente: Ante-sala da Congregação}

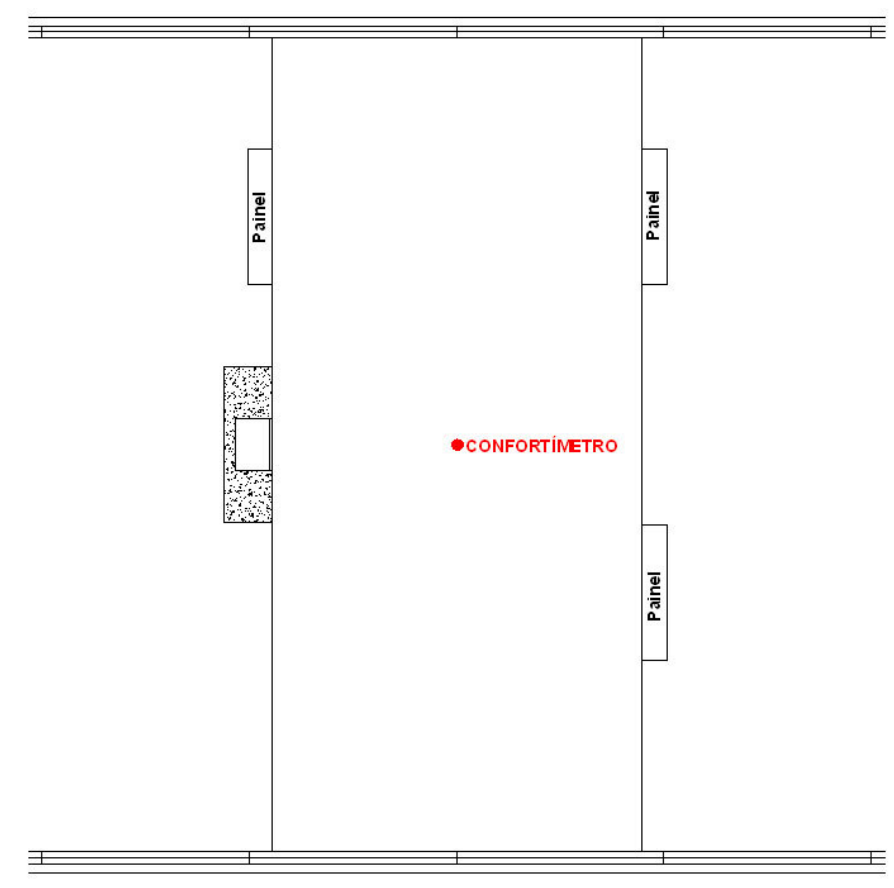

Figura 102 - Planta - Ante-sala da Congregação - localização do confortímetro

Resultados do período 1: Dia: 23/11/2006

Janelas fechadas

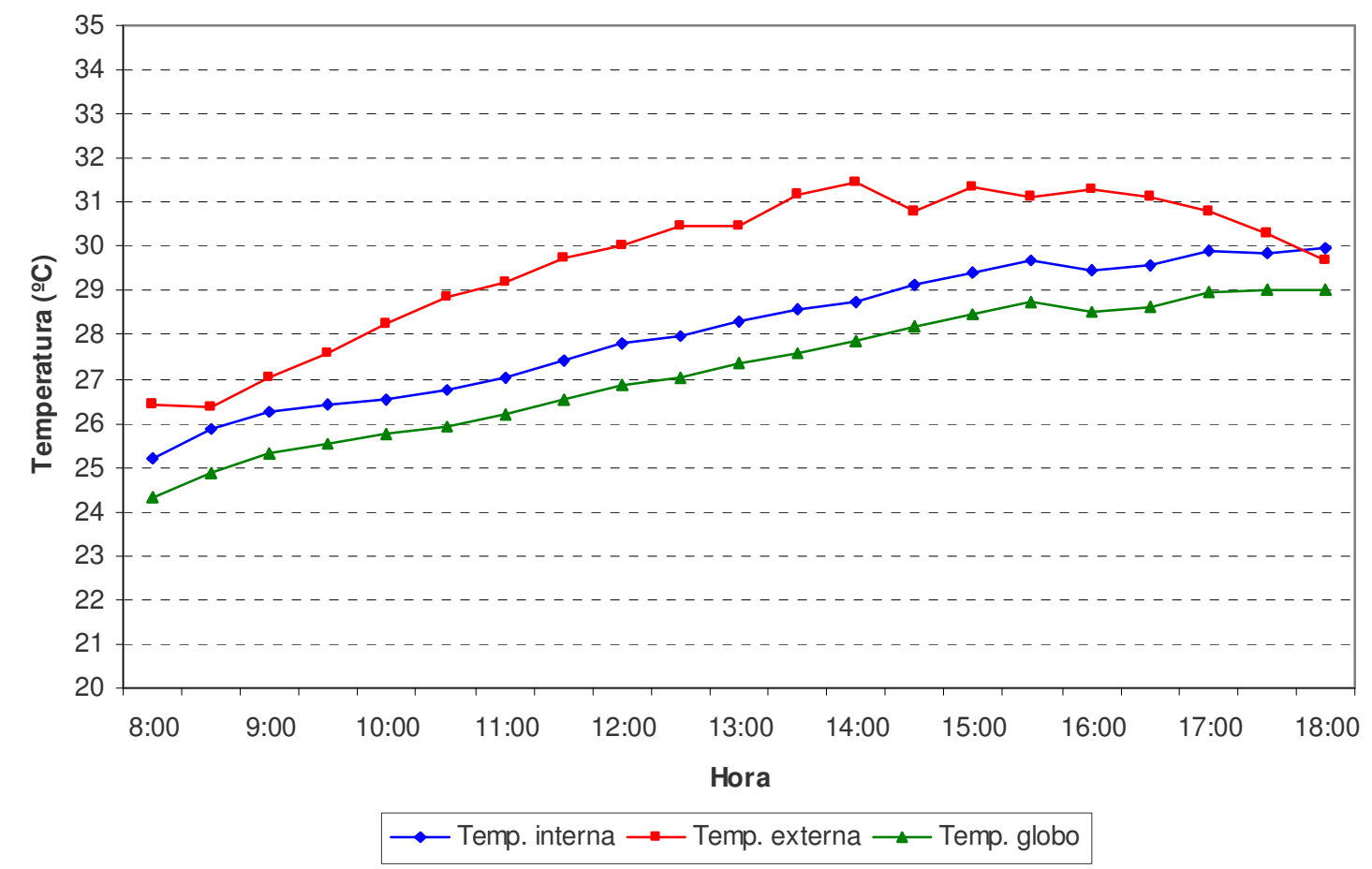

Figura 103 - Temperatura do ar - 23/11/2006 
De modo geral, a temperatura interna para 0 dia 23/11/2006, considerando todas as janelas fechadas, foi se elevando ao longo do dia, porém mantendo-se sempre abaixo da temperatura externa. A média das temperaturas externas foi de $29,69^{\circ} \mathrm{C}$, enquanto a média das internas foi de $28,09^{\circ} \mathrm{C}$, constatando-se uma diferença de $1,6^{\circ} \mathrm{C}$. A temperatura interna máxima atingida foi de $29,98^{\circ} \mathrm{C}$ às $18 \mathrm{~h} 00 \mathrm{~min}$.

Tabela 14 - PMV e PPD - 23/11/2
\begin{tabular}{|c|c|c|}
\hline HORA & PMV & PPD \\
\hline $8: 00$ & -0.28 & 6.61 \\
\hline $8: 30$ & -0.02 & 5.01 \\
\hline $9: 00$ & 0.02 & 5.01 \\
\hline $9: 30$ & 0.06 & 5.08 \\
\hline $10: 00$ & 0.14 & 5.39 \\
\hline $10: 30$ & 0.12 & 5.28 \\
\hline $11: 00$ & 0.23 & 6.13 \\
\hline $11: 30$ & 0.43 & 8.78 \\
\hline $12: 00$ & 0.55 & 11.39 \\
\hline $12: 30$ & 0.62 & 13.08 \\
\hline $13: 00$ & 0.67 & 14.35 \\
\hline $13: 30$ & 0.78 & 17.70 \\
\hline $14: 00$ & 0.82 & 19.24 \\
\hline $14: 30$ & 0.94 & 23.80 \\
\hline $15: 00$ & 1.02 & 26.87 \\
\hline $15: 30$ & 1.13 & 32.07 \\
\hline $16: 00$ & 1.07 & 29.01 \\
\hline $16: 30$ & 1.12 & 31.47 \\
\hline $17: 00$ & 1.16 & 33.12 \\
\hline $17: 30$ & 1.14 & 32.19 \\
\hline $18: 00$ & 1.17 & 33.77 \\
\hline
\end{tabular}

Os valores para o índice PMV correspondentes ao dia 23/11/2006 variaram desde -0.28 , que corresponde a neutro a 1.17 , que corresponde a levemente quente. Os valores correspondentes a neutro se concentraram desde a primeira hora da manhã até às $11 \mathrm{~h} 30 \mathrm{~min}$. A partir das $12 \mathrm{~h} 00 \mathrm{~min}$ os valores corresponderam a levemente quente, permanecendo assim até às 18h00min. Pode-se dizer que durante esse dia, no período de atividades do edifício, na maior parte do tempo o PMV foi próximo a 1, ou seja, levemente quente. 
Resultados do período 1: Dia: 24/11/2006

Janelas abertas na parte central

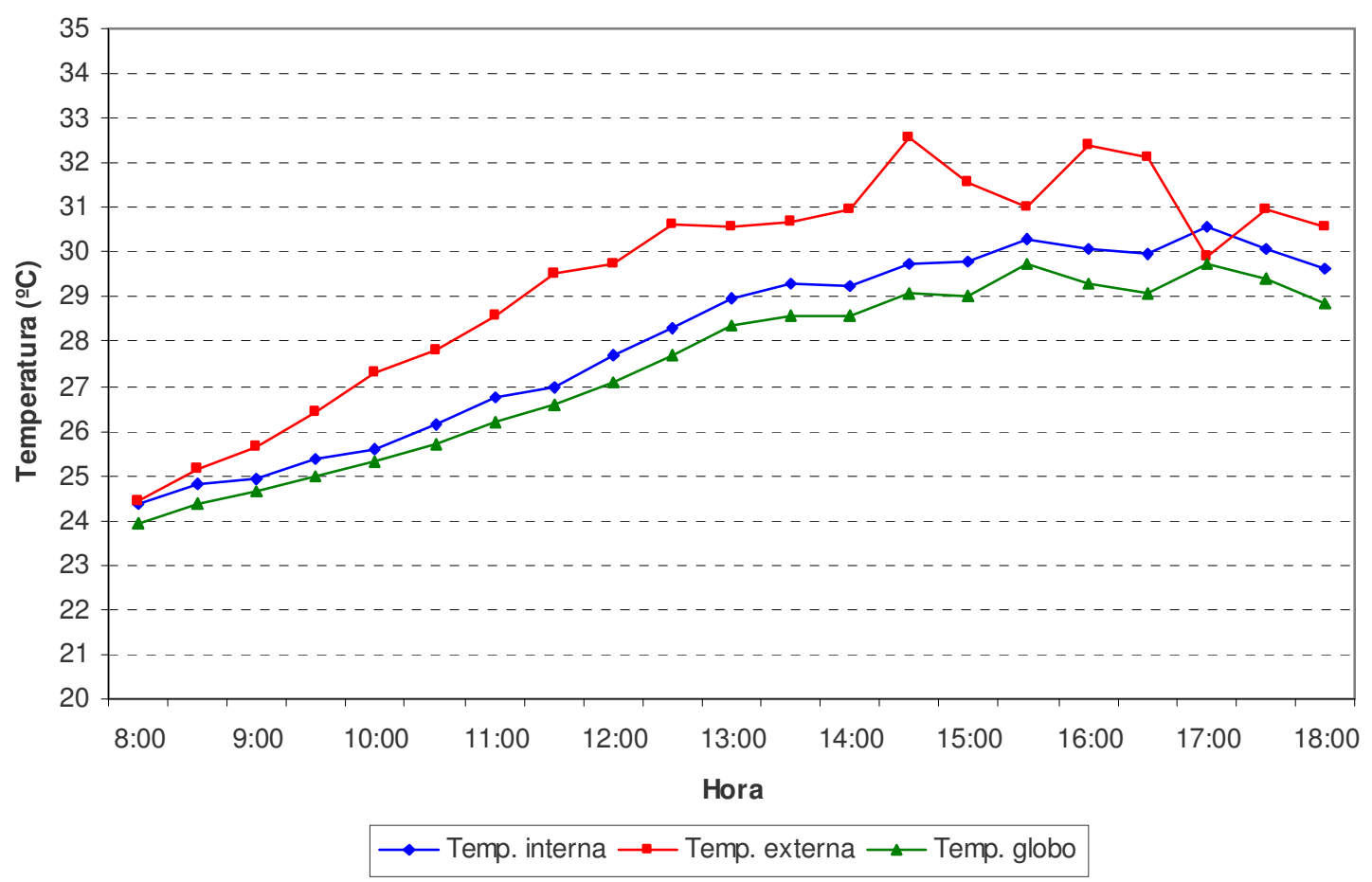

Figura 104 - Temperatura do ar - 24/11/2006

De modo geral, a temperatura interna para o dia 24/11/2006, considerando as janelas abertas na faixa central, foi se elevando ao longo do dia, mantendo-se na maior parte do dia abaixo da temperatura externa. A média das temperaturas externas foi de $29,45^{\circ} \mathrm{C}$, enquanto a média das internas foi de $28,03^{\circ} \mathrm{C}$, constatando-se uma diferença de $1,42^{\circ} \mathrm{C}$. A temperatura interna máxima atingida foi de $30,56^{\circ} \mathrm{C}$ às $17 \mathrm{~h} 00 \mathrm{~min}$. 


\section{Tabela 15 - PMV e PPD - 24/11/2006}

\begin{tabular}{|c|c|c|}
\hline HORA & PMV & PPD \\
\hline $8: 00$ & -0.91 & 22.57 \\
\hline $8: 30$ & -0.78 & 17.82 \\
\hline $9: 00$ & -0.78 & 17.83 \\
\hline $9: 30$ & -0.64 & 13.63 \\
\hline $10: 00$ & -0.58 & 12.00 \\
\hline $10: 30$ & -0.39 & 8.18 \\
\hline $11: 00$ & -0.21 & 5.88 \\
\hline $11: 30$ & -0.04 & 5.04 \\
\hline $12: 00$ & 0.26 & 6.39 \\
\hline $12: 30$ & 0.56 & 11.50 \\
\hline $13: 00$ & 0.82 & 19.34 \\
\hline $13: 30$ & 0.94 & 23.74 \\
\hline $14: 00$ & 0.97 & 24.73 \\
\hline $14: 30$ & 1.15 & 32.94 \\
\hline $15: 00$ & 1.10 & 30.35 \\
\hline $15: 30$ & 1.30 & 40.24 \\
\hline $16: 00$ & 1.15 & 32.98 \\
\hline $16: 30$ & 1.24 & 37.23 \\
\hline $17: 00$ & 1.36 & 43.17 \\
\hline $17: 30$ & 1.28 & 39.02 \\
\hline $18: 00$ & 1.15 & 33.06 \\
\hline
\end{tabular}

Os valores para o índice PMV correspondentes ao dia 24/11/2006 variaram desde -0.91 , que corresponde a levemente frio a 1.36 , que corresponde a levemente quente. Os valores correspondentes a levemente frio se concentraram nas duas primeiras horas da manhã. Das 10h30min até às $12 \mathrm{~h} 00 \mathrm{~min}$ os valores correspondem a PMV neutro. A partir das $12 \mathrm{~h} 30 \mathrm{~min}$ os valores corresponderam a levemente quente, permanecendo assim até às 18h00min. Pode-se dizer que durante esse dia, no período de atividades do edifício, na maior parte do tempo o PMV foi próximo a 1, ou seja, levemente quente. 
Resultados do período 2: Dia: 13/03/2007

Janelas abertas: faixa central - fachadas norte e sul

faixa inferior - fachada norte

faixa superior - fachada sul

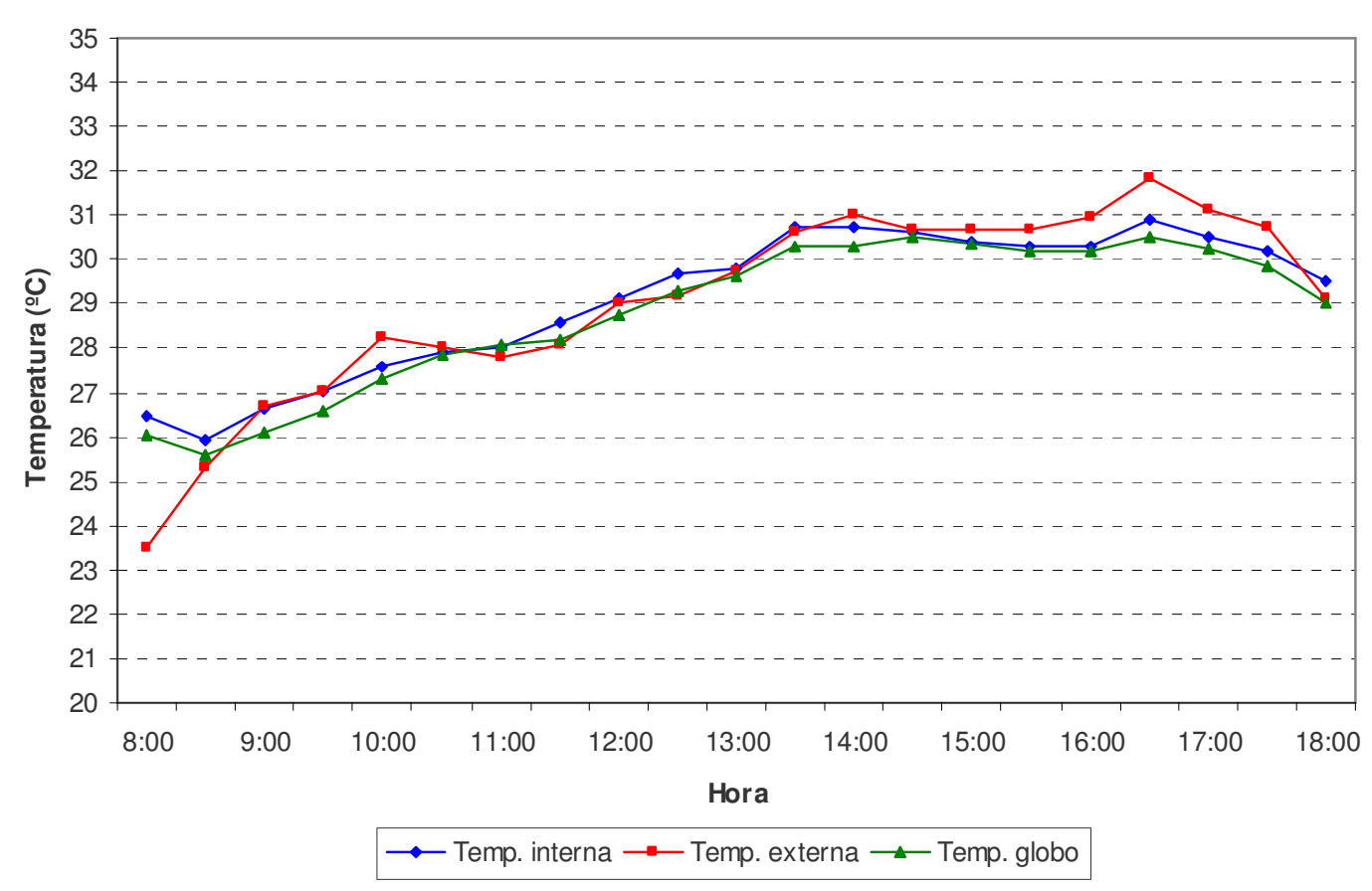

Figura 105 - Temperatura do ar - 13/03/2007

De modo geral, a temperatura interna para o dia 13/03/2007, considerando as janelas conforme descrito acima, manteve-se muito próxima da temperatura externa durante todo o período de medição. A média das temperaturas externas foi de $29,04^{\circ} \mathrm{C}$, enquanto a média das internas foi de $29,10^{\circ} \mathrm{C}$. A temperatura interna máxima atingida foi de $30,93^{\circ} \mathrm{C}$ às $16 \mathrm{~h} 30 \mathrm{~min}$. 
Tabela 16 - PMV e PPD - 13/03/2007

\begin{tabular}{|c|c|c|}
\hline HORA & PMV & PPD \\
\hline $8: 00$ & 0.15 & 5.47 \\
\hline $8: 30$ & -0.16 & 5.53 \\
\hline $9: 00$ & 0.07 & 5.10 \\
\hline $9: 30$ & 0.19 & 5.76 \\
\hline $10: 00$ & 0.26 & 6.46 \\
\hline $10: 30$ & 0.34 & 7.37 \\
\hline $11: 00$ & 0.35 & 7.53 \\
\hline $11: 30$ & 0.70 & 15.26 \\
\hline $12: 00$ & 0.80 & 18.35 \\
\hline $12: 30$ & 0.99 & 25.90 \\
\hline $13: 00$ & 1.11 & 30.96 \\
\hline $13: 30$ & 1.46 & 48.75 \\
\hline $14: 00$ & 1.47 & 49.42 \\
\hline $14: 30$ & 1.44 & 47.91 \\
\hline $15: 00$ & 1.36 & 43.62 \\
\hline $15: 30$ & 1.34 & 42.51 \\
\hline $16: 00$ & 1.26 & 38.38 \\
\hline $16: 30$ & 1.52 & 52.13 \\
\hline $17: 00$ & 1.39 & 45.24 \\
\hline $17: 30$ & 1.28 & 39.33 \\
\hline $18: 00$ & 1.17 & 33.85 \\
\hline
\end{tabular}

Os valores para o índice PMV correspondentes ao dia 13/03/2007 variaram desde -0.16 , que corresponde a neutro a 1.52 , que corresponde a quente. Os valores correspondentes a neutro se concentraram nas três primeiras horas da manhã. A partir das $11 \mathrm{~h} 30 \mathrm{~min}$ os valores corresponderam a levemente quente, permanecendo assim até às 18h00min. Apenas no horário das $16 \mathrm{~h} 30 \mathrm{~min}$ o PMV corresponde a quente.

Pode-se dizer que durante esse dia, no período de atividades do edifício, na maior parte do tempo o PMV foi próximo a 1, ou seja, levemente quente. 
Resultados do período 3: Dia: 03/06/2007

Janelas fechadas

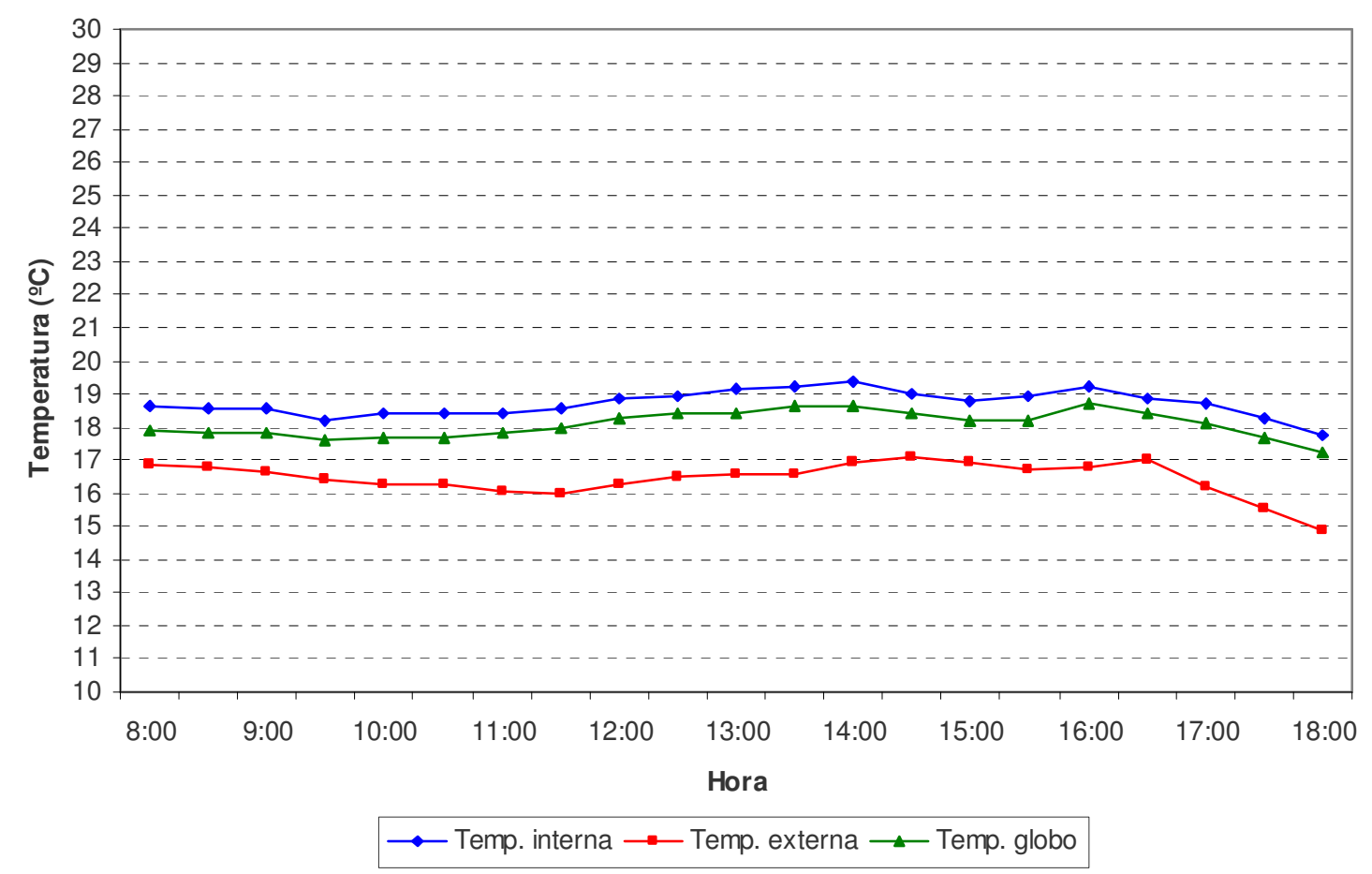

Figura 106 - Temperatura do ar - 03/06/2007

De modo geral, a temperatura interna para o dia 03/06/2007, considerando as janelas fechadas, manteve-se acima da temperatura externa durante todo o período de medição. A média das temperaturas externas foi de $16,44^{\circ} \mathrm{C}$, enquanto a média das internas foi de $18,71^{\circ} \mathrm{C}$, constatando-se uma diferença de $2,27^{\circ} \mathrm{C}$. A temperatura interna máxima atingida foi de $19,34^{\circ} \mathrm{C}$ às 14h00min e a mínima $17,77^{\circ} \mathrm{C}$ às $18 \mathrm{~h} 00 \mathrm{~min}$. 
Tabela 17 - PMV e PPD - 03/06/2007

\begin{tabular}{|c|c|c|}
\hline HORA & PMV & PPD \\
\hline $8: 00$ & -1.47 & 49.54 \\
\hline $8: 30$ & -1.45 & 48.41 \\
\hline $9: 00$ & -1.49 & 50.53 \\
\hline $9: 30$ & -1.62 & 57.61 \\
\hline $10: 00$ & -1.51 & 51.26 \\
\hline $10: 30$ & -1.35 & 43.10 \\
\hline $11: 00$ & -1.40 & 45.73 \\
\hline $11: 30$ & -1.46 & 48.92 \\
\hline $12: 00$ & -1.30 & 40.08 \\
\hline $12: 30$ & -1.26 & 38.18 \\
\hline $13: 00$ & -1.25 & 37.58 \\
\hline $13: 30$ & -1.14 & 32.17 \\
\hline $14: 00$ & -1.22 & 36.39 \\
\hline $14: 30$ & -1.31 & 40.54 \\
\hline $15: 00$ & -1.31 & 40.56 \\
\hline $15: 30$ & -1.35 & 42.79 \\
\hline $16: 00$ & -1.33 & 41.74 \\
\hline $16: 30$ & -1.42 & 46.84 \\
\hline $17: 00$ & -1.29 & 39.86 \\
\hline $17: 30$ & -1.55 & 53.35 \\
\hline $18: 00$ & -1.81 & 67.71 \\
\hline
\end{tabular}

Os valores para o índice PMV correspondentes ao dia 03/06/2007 variaram desde -1.81, que corresponde a frio a -1.14 , que corresponde a levemente frio. Os valores de PMV ficaram a maior parte do dia próximos a -1, que corresponde a levemente frio. 
Resultados do período 4: Dia: 07/07/2007

Janelas fechadas

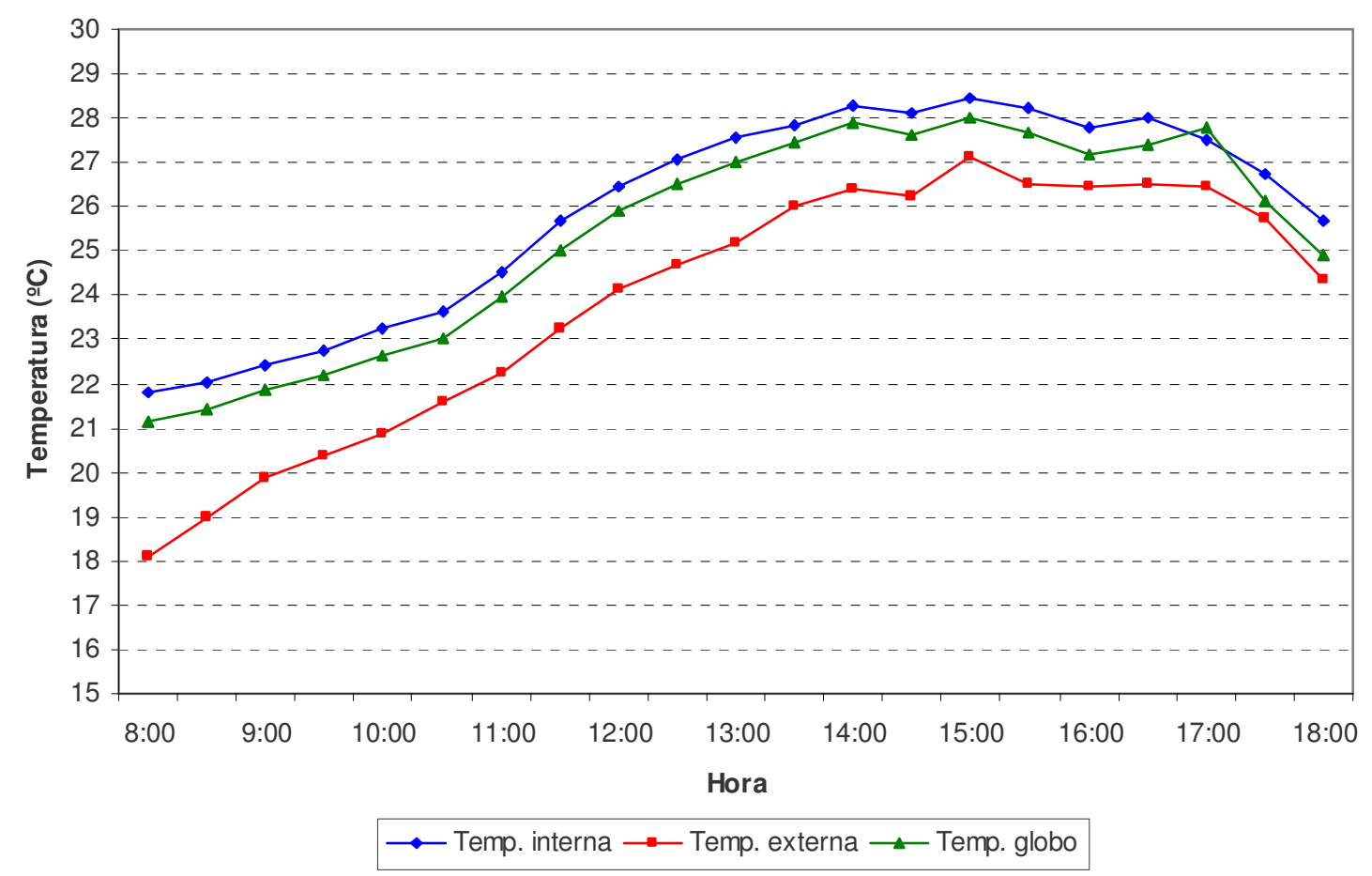

Figura 107 - Temperatura do ar - 07/07/2007

De modo geral, a temperatura interna para 0 dia 07/07/2007, considerando as janelas fechadas, manteve-se acima da temperatura externa durante todo o período de medição. A média das temperaturas externas foi de $23,86^{\circ} \mathrm{C}$, enquanto a média das internas foi de $25,89^{\circ} \mathrm{C}$, constatando-se uma diferença de $2,03^{\circ} \mathrm{C}$. A temperatura interna máxima atingida foi de $28,44^{\circ} \mathrm{C}$ às 15 h00min e a mínima $21,80^{\circ} \mathrm{C}$ às 08 h00min. 
Tabela 18 - PMV e PPD - 07/07/2007

\begin{tabular}{|c|c|c|}
\hline HORA & PMV & PPD \\
\hline $8: 00$ & -0.71 & 15.51 \\
\hline $8: 30$ & -0.66 & 14.11 \\
\hline $9: 00$ & -0.37 & 7.77 \\
\hline $9: 30$ & -0.30 & 6.85 \\
\hline $10: 00$ & -0.27 & 6.54 \\
\hline $10: 30$ & -0.07 & 5.11 \\
\hline $11: 00$ & 0.15 & 5.44 \\
\hline $11: 30$ & 0.47 & 9.65 \\
\hline $12: 00$ & 0.62 & 13.13 \\
\hline $12: 30$ & 0.82 & 19.06 \\
\hline $13: 00$ & 0.95 & 24.25 \\
\hline $13: 30$ & 1.02 & 26.97 \\
\hline $14: 00$ & 1.17 & 33.77 \\
\hline $14: 30$ & 1.14 & 32.34 \\
\hline $15: 00$ & 1.23 & 36.84 \\
\hline $15: 30$ & 1.16 & 33.42 \\
\hline $16: 00$ & 1.01 & 26.52 \\
\hline $16: 30$ & 1.05 & 28.44 \\
\hline $17: 00$ & 1.05 & 28.21 \\
\hline $17: 30$ & 0.79 & 18.12 \\
\hline $18: 00$ & 0.51 & 10.33 \\
\hline
\end{tabular}

Os valores para o índice PMV correspondentes ao dia 07/07/2007 variaram desde -0.71 , que corresponde a frio a 1.23 , que corresponde a levemente quente. Os valores correspondentes a levemente frio se concentraram na primeira hora da manhã. A partir das 09h00min até às $11 \mathrm{~h} 30 \mathrm{~min}$ os valores corresponderam a neutro. E das 12h00min até o final do expediente os valores correspondem a levemente quente. Pode-se dizer que durante esse dia, no período de atividades do edifício, na maior parte do tempo o PMV foi próximo a 1, ou seja, levemente quente.

\subsection{Considerações finais}

O Bloco E1 possui uma importância histórica muito grande, tanto para a arquitetura como para a Escola de Engenharia de São Carlos. O edifício pode ser considerado um ícone da Arquitetura Moderna, com características fortemente presentes como planta livre, pilotis, fachada livre e envidraçada e 
terraço-jardim. Experimentou muitas técnicas e sistemas construtivos novos, sendo uma farta fonte de estudos para várias áreas.

O destaque da edificação é comprovado com a sua grande utilização até os dias atuais. Muitas das técnicas visando conforto ambiental empregadas nesse prédio tiveram boa aceitação por parte de seus usuários, destacando que, em mais de 50 anos de existência, não foi levantada a necessidade do uso de aparelhos que promovessem ventilação artificial, como ar condicionado. Essas mesmas técnicas, se aplicadas a edifícios escolares e de escritórios, certamente promoveriam uma grande economia de energia.

O uso otimizado da ventilação natural, o emprego de materiais de forma adequada e o aproveitamento de luz natural em edificações, usadas principalmente durante o dia, produzem uma contribuição significativa para a redução do consumo de energia elétrica, além de melhoria do conforto ambiental e bem-estar dos ocupantes.

A partir dos resultados obtidos na parte prática desta pesquisa, em relação à iluminação, foi realizada uma comparação entre os resultados obtidos nos questionários e os resultados obtidos nas medições dos níveis de iluminância, podendo-se notar que se completam, já que os valores de iluminância obtidos não atingem, na maioria das vezes, o valor de 750 lux, estabelecido pela norma ABNT (1992). Isso só vem a confirmar as repostas dos usuários do Bloco E1 quanto a necessidade do uso da iluminação artificial que é diária, tanto no verão como no inverno, e de forma constante.

Todavia, sobre os níveis de iluminância obtidos, deve-se destacar que estes foram medidos em duas salas do Bloco $E 1$, com configurações diferentes, a sala da Assistência Administrativa possui corredor e divisórias voltados para a fachada norte, enquanto a Ante-sala da Congregação possui comunicação direta com o exterior. Em uma comparação entre os resultados obtidos nas duas salas chega-se que o comportamento da Ante-sala da Congregação foi melhor, principalmente no verão.

Ainda sobre a iluminação é importante realizar observações sobre a iluminação artificial utilizada no edifício. Considerando o uso de escritórios e com base no layout e auxilio de curvas isolux, deveria ser realizado um novo projeto focado na setorização, iluminação direta e mais forte nas áreas onde é necessária e mais fraca, por exemplo, em corredores. Nesse projeto também é 
extremamente necessário a readequação das divisórias, possibilitando a entrada de luz natural pelas fachadas sul e norte. É importante também realizar uma conscientização dos funcionários quanto ao uso das persianas (abertura e fechamento), deixando-os informados sobre as estratégias do novo projeto e a participação deles para que se obtenha o resultado desejado. Claro que não será possível a utilização exclusiva da luz natural, mas com algumas readequações é possível minimizar o uso da iluminação artificial, diminuindo assim os gastos energéticos.

Outra questão a ser destacada no Bloco E1, é a sua sensação quanto à transparência, que com o projeto inicial desejava-se que fosse agradável. Nas respostas dos funcionários, no questionário, o resultado confirmou essa sensação, o que realmente valoriza o edifício.

Realizando uma comparação entre os resultados dos questionários obtidos nas perguntas relacionadas à sensação térmica no verão e no inverno, e os índices PMV gerados a partir das medições in loco das variáveis ambientais, pode-se notar que houve uma disparidade. As sensações térmicas relatadas pelos usuários do Bloco E1 apresentaram valores diferentes das obtidas a partir das medições, como por exemplo, no período correspondente ao verão, em que a maior parte das respostas dos usuários correspondeu a quente, enquanto o PMV calculado a partir das medições, para o mesmo período, correspondeu, predominantemente, a levemente quente.

A compreensão desta situação pode partir da questão dos usuários não saberem e não utilizarem os recursos que as aberturas do edifício oferecem. Das três faixas de aberturas existentes em cada módulo de caixilho só é utilizada a central, a faixa inferior e a superior nunca são abertas, e muitos funcionários nem sabem que abrem.

Os resultados obtidos nas medições das variáveis ambientais foram muito satisfatórios, nos períodos mais quentes a temperatura interna mantevese, na maioria das vezes, abaixo da temperatura externa, e nos períodos mais frios, a temperatura interna manteve-se, na maior parte das vezes, acima da temperatura externa.

Quanto aos índices PMV e PPD calculados a partir das medições podese dizer que de forma geral apresentaram resultados satisfatórios, já que com base na escala de sensação térmica de sete pontos, os valores que 
predominaram ao longo das medições correspondem a levemente frio, neutro e levemente quente.

Deve-se destacar que com mudança de layout, a modificação das divisórias internas, a conscientização do uso de persianas e aberturas, e setorização da iluminação artificial, focando a iluminação direta nos postos de trabalho, os ambientes obteriam melhorias na ventilação natural e diminuição do uso da iluminação artificial, favorecendo a diminuição dos gastos energéticos do prédio. Sendo que o Bloco E1 quanto ao seu condicionamento térmico traz uma contribuição significativa com os gastos energéticos, já que não são utilizados aparelhos de ar condicionado. Esta característica do edifício é resultado de uma forte estratégia de projeto, diferenciando-o em relação a outros edifícios do mesmo padrão.

A partir das estratégias de projeto expostas nesta pesquisa, a constatação de eficácia, as discussões e a explanação de como o prédio é utilizado por seus ocupantes pode-se contribuir com projetos e readequações de edifícios que visem conforto térmico, conforto visual e eficiência energética. 



\section{CONCLUSÕES}

- Os valores de iluminância obtidos não atingiram, na maioria das vezes, o valor de 750 lux, estabelecido pela norma ABNT (1992).

- Os resultados obtidos nas medições das variáveis ambientais foram muito satisfatórios, nos períodos mais quentes a temperatura interna manteve-se, na maioria das vezes, abaixo da temperatura externa, e nos períodos mais frios, a temperatura interna manteve-se, na maior parte das vezes, acima da temperatura externa.

- Os índices PMV e PPD de forma geral apresentaram resultados satisfatórios.

- A orientação da edificação, sua forma, o emprego adequado dos materiais, o projeto das fachadas e esquadrias, e a ventilação natural contribuem para o bom resultado no conforto térmico dos ocupantes.

- A edificação poderia obter uma diminuição nos gastos energéticos com a mudança de layout, a modificação das divisórias internas, a conscientização do uso de persianas e aberturas, e setorização da iluminação artificial.

Como sugestões para futuros trabalhos, podem-se propor:

- Com base nos resultados obtidos nesta pesquisa, realizar o desenho para um novo layout para o Bloco E1, podendo aplicar as estratégias desenvolvidas por Mange e propor novas estratégias.

- Realizar uma análise comparativa entre o Bloco E1 e outros prédios do campus da USP - São Carlos, do ponto de vista de conforto ambiental. 



\section{REFERÊNCIAS}

AKUTSU, M. (1998). Método para avaliação do desempenho térmico de edificações no Brasil. Tese (Doutorado) - Faculdade de Arquitetura e Urbanismo São Paulo, Universidade de São Paulo, São Paulo, 1998.

. (1993). Abordagem integrada do controle térmico e acústico em edificações. Construção São Paulo, São Paulo, n.2372, p.27-30, jul.

ALLARD, F. (1998). Natural ventilation in buildings - a design handbook. Londres: Mat Santamouris.

ALTAFIM, R.A.C. (Org.). (2004). 50 anos da EESC: um olhar no passado visando ao futuro. São Carlos: EESC/USP.

ALUCCI, M.P. (1992). Conforto térmico, conforto luminoso e conservação de energia elétrica: procedimentos para o desenvolvimento e avaliação de projeto de edificações. Tese (Doutorado) - Faculdade de Arquitetura e Urbanismo São Paulo, Universidade de São Paulo, São Paulo, 1992.

. (1998). Recomendações de uma edificação ao clima no estado de São Paulo. Dissertação (Mestrado) - Faculdade de Arquitetura e Urbanismo São Paulo, Universidade de São Paulo, São Paulo, 1998.

AMADEI, J. (1951). O Que é convênio escolar. Habitat, São Paulo, v.1, n.4, p.3, jul./set.

AMARAL, M.G.V. (1999). Iluminação natural: revisão da legislação construtiva em Florianópolis. Dissertação (Mestrado) - Universidade Federal de Santa Catarina, Florianópolis, 1999.

ARAÚJO, C.G. (2004). Arquitetura e cidade na obra de Ernest de Carvalho Mange. Dissertação (Mestrado) - Escola de Engenharia de São Carlos, Universidade de São Paulo, São Carlos, 2004.

ARAÚJO, V.M.D. (2001). Parâmetros de conforto térmico para usuários de edificações escolares. Natal: EDUFRN.

ASHRAE handbook: fundamentals. (1993). Atlanta: ASHRA. 
ASSOCIAÇÃO BRASILEIRA DE NORMAS TÉCNICAS (1985). NBR 5382: Verificação de iluminância de Interiores. Rio de Janeiro.

. (1991). NBR 5461: lluminação - terminologia. Rio de Janeiro.

. (1992). NBR 5413: lluminância de interiores - procedimento. Rio de

$\overline{\text { Janeiro. }}$

(2005). NBR 15220-1: Desempenho térmico de edificações - parte 1: Definições, símbolos e unidades. Rio de Janeiro.

. (2005a). NBR 15215-1: lluminação natural - parte 1: conceitos básicos e definições. Rio de Janeiro.

. (2005b). NBR 15215-2: lluminação natural - parte 2: procedimentos de cálculo para a estimativa da disponibilidade de luz natural. Rio de Janeiro.

. (2005c). NBR 15215-3: lluminação natural - parte 3: procedimentos de cálculo para a determinação da iluminação natural em ambientes internos. Rio de Janeiro.

. (2005d). NBR 15215-4: lluminação natural - parte 4: verificação experimental das condições de iluminação interna de edificações - método de medição. Rio de Janeiro.

BAKER, N.; FANCHIOTTI, A.; STEEMERS, K. (1993). Daylighting in architecture: a european reference book. London: James \& James Science.

BEGUIN, F. (1991). As Maquinarias inglesas do conforto. Espaço \& Debates, São Paulo, ano 11, n.34, p.39-54.

BERTE, V.A. (2000). Acondicionamento térmico natural: análise de caso na cidade de Uberlância-MG. Dissertação (Mestrado) - Faculdade de Arquitetura e Urbanismo São Paulo, Universidade de São Paulo, São Paulo, 2000.

BLOCO E1: fotos diversas. (2005). São Carlos: Seção de Documentação e Cadastro da Divisão de Obras/USP. 1 CD-ROM.

BONDUKI, N. (1998). Origens da habitação social no Brasil. São Paulo: Estação Liberdade; FAPESP.

BRASIL. Ministério da Agricultura e Reforma Agrária. Secretária Nacional de Irrigação. Departamento Nacional de Meteorologia. (1992). Normais climatológicas (1961-1990). Brasília: Departamento Nacional de Meteorologia.

BRESCIANI, M.S.M. (1985). Lógica e dissonância sociedade de trabalho: lei, ciência, disciplina e resistência operária. Revista Brasileira de História, São Paulo, n.11, p. 6-44. 
BRUNA, G.C.; ROMERO, M.A.; LIMA; C.P.C.S.L. (1995). Avaliação pósocupação e redesenho de habitações de interesse social: um estudo de caso, São Paulo, Brasil. Sinopses, São Paulo, n.23, p.11-23, jun.

CAMOUS, R. (1983). El Habitat bioclimatico. Barcelona: Gustavo Gili.

CARAM, R.M. (1998). Caracterização ótica de materiais transparentes e sua relação com o conforto ambiental em edificações. Tese (Doutorado) Faculdade de Engenharia Civil, Universidade Estadual de Campinas, Campinas, 1998.

. (2002). Estudo e caracterização de fachadas transparentes para uso na arquitetura: ênfase na eficiência energética. Tese (Livre-Docência) Escola de Engenharia de São Carlos, Universidade de São Paulo, São Carlos, 2002.

(1996). Vidros e o conforto ambiental: indicativos para o emprego apropriado de vidros planos na construção civil. Dissertação (Mestrado) Escola de Engenharia de São Carlos, Universidade de São Paulo, São Carlos, 1996.

CARPINTEIRO, M.V.T. (1997). A Construção de um sonho os engenheirosarquitetos e a formulação da política habitacional no Brasil (São Paulo 1917/1940). Campinas: UNICAMP.

CARVALHO, T.C.P. (2001). Análise do comportamento térmico de uma habitação de madeira em pinus roliço, sob determinadas condições de exposição, para a cidade de São Carlos-SP. In: ENCONTRO NACIONAL DE CONFORTO NO AMBIENTE CONSTRUÍDO, 6./ ENCONTRO LATINOAMERICANO DE CONFORTO NO AMBIENTE CONSTRUÍDO, 3., 2001, São Pedro. Anais... [S.I.]: ANTAC. 1 CD-ROM.

CHICHIERCHIO, L.C. (1985). Enfoque bioclimático da arquitetura e dos assentamentos humanos: fundamentos do controle ambiental. In: SEMINÁRIO NACIONAL DE ARQUITETURA NOS TRÓPICOS, 1985, Recife. Anais... Recife: FUNDAJ; Massangana. p.100-124.

CLARKE, J. (1993). Energy simulation and building design in ESP-r training course. Glasgow: University of Strathclyde.

CORBIN, A. (1987). Saberes e odores: o olfato e o imaginário social nos séculos XVIII e XIX. São Paulo: Companhia das Letras.

CORREIA, T.B. (2004). A Construção do habitat moderno no Brasil - 18701950. São Carlos: RiMa.

COWAN, H.J. (1980). Solar energy application in the design of buildings. London: Applied Science.

DUARTE, H.Q. (1951). O Problema escolar e a arquitetura. Habitat, São Paulo, v.1, n.4, p.4-6, jul./set. 
. (1956a). Considerações sobre arquitetura e educação. Acrópole, São Paulo, ano 18, n.210, p.236-238.

. (1956b). Roteiro do planejamento da Cidade Universitária Armando Salles Oliveira. São Paulo: USP.

(1957). Espaços flexíveis. Tese (Livre-Docências) - Faculdade Nacional de Arquitetura, Universidade do Brasil, São Paulo, 1957.

DUARTE, H.Q.; MANGE, E.R.C. (1954). Contribuição ao ensino de arquitetura. São Paulo: [s.n.].

. (1956). Escola de Engenharia de São Carlos. Habitat, São Paulo, v.6, n.33, p.44-49, ago.

. (1957). Plano da Cidade Universitária de Santa Catarina.

Florianópolis: UFSC.

. [195-]. Coleção de desenhos referentes ao projeto do Bloco E1. São Carlos: Seção de Documentação e Cadastro da Divisão de Obras/USP.

ECO, H. (1983). Como se faz uma tese. São Paulo: Perspectivas.

EESC - 21 anos a serviço do ensino e da Pesquisa. (1977). São Carlos: EESC/USP.

FANGER, O. (1970). Thermal comfort - analysis and application in environmental engineering. New York: MacGraw-Hill.

FERREIRA, A.R.L.F. (2004). O Campus da USP em São Carlos: projetos arquitetônicos e urbanísticos modernos. Relatório (Iniciação Cientifica) Escola de Engenharia de São Carlos, Universidade de São Paulo, São Carlos.

FIORI, A.M. (2001). Um método para medir a sombra. Pesquisa FAPESP, São Paulo, n.61, p.26-29, jan./fev.

FOUCAULT, M. (1981). O Nascimento da medicina social. In: Microfísica do poder. Rio de Janeiro: Graal. p.79-98.

FROTA, A.B.; SCHIFFER, S.R. (1988). Manual de conforto térmico. São Paulo: Nobel.

FROTA, A.B. (2004). Geometria da insolação. São Paulo: Geros.

GAMMARANO, B. (1992). As Fachadas de vidro e o modernismo: uma reflexão. Dissertação (Mestrado) - Faculdade de Arquitetura e Urbanismo, Universidade Federal do Rio de Janeiro, Rio de Janeiro, 1992.

GENCIAUSKAS, S. (1997). Evolução das fachadas-cortina na arquitetura brasileira. Finestra Brasil, ano 3, n.11, p.108-111. 
GIL, A.C. (2002). Como elaborar projetos de pesquisa. São Paulo: Atlas.

GIVONI, B. (1981). Man, climate and architecture. London: Applied Science. John Wiley. (1994). Passive and low energy cooling of buildings. New York:

GOMES, C.H.G. (2003). Análise dos níveis de conforto térmico em um edifício de escritórios na cidade de Maringá. Dissertação (Mestrado) Universidade Federal de Santa Catarina, Florianópolis, 2003).

GUERRAND, R.H. (1991). Espaços privados. In: HISTÓRIA da vida privada. São Paulo: Companhia das Letras. v.4, p.325-411.

HARKNESS, E.L. (1978). Solar radiation control in buildings. London: Applied Science.

HERNANDEZ, N.A. er al. (1999). Avaliação da viabilidade econômica de soluções de envidraçamento. In: ENCONTRO NACIONAL SOBRE CONFORTO NO AMBIENTE CONSTRUÍDO, 5., 1999, Fortaleza. Anais... Fortaleza: [s.n.]. 1 CD-ROM.

HERZOG, T. (1998). Solar energy in architecture and urban planning. Munich: Prestel.

HOPKINSON, R.G.; PETHERBRIDGE, P.; LONGMORE, J. (1966).

lluminação natural. Lisboa: Fundação Calouste Gulbenkian.

HUGENTOBLER, P. (1997). Fachada em sintonia com a luz e o calor.

Finestra Brasil, ano 3, n.11, p.80-91.

INTERNATIONAL ORGANIZATION FOR STANDARDIZATION (2005). ISO 7730: Ergonomics of the thermal environment - analytical determination and interpretation of thermal comfort using calculation of the PMV and PPD indices and local thermal comfort criteria. Geneva.

IZARD, J.L. (1980). Arquitetura bioclimática. Barcelona: Gili.

JORGE, L.A. (1995). O Desenho da janela. São Paulo: AnnaBlume.

KOENIGSBERGER, O.H. et al. (1977). Viviendas y edificios en zonas cálidas y tropicales. Madrid: Paraninfo.

KOWALTOWSKI, D. et al. (2000). Manual de conforto ambiental. Campinas: [s.n.].

LABAKI, L.C.; CARAM, R.M.; SICHIERI, E.P. (1995). Os Vidros e o conforto ambiental. In: ENCONTRO NACIONAL DE CONFORTO NO AMBIENTE CONSTRUÍDO, 3./ ENCONTRO LATINO-AMERICANO DE CONFORTO NO 
AMBIENTE CONSTRUÍDO, 1995, Gramado. Anais... São Paulo: [s.n.]. p.215-220.

LAMBERTS, R.; XAVIER, A. A. P. (2002). Conforto térmico e stress térmico. Florianópolis: Universidade Federal de Santa Catarina, Centro Tecnológico, Departamento de Engenharia Civil.

LAMBERTS, R.; DUTRA, L.; PEREIRA, F.O.R. (2004). Eficiência energética na arquitetura. São Paulo: Pro Livros.

LEME, M.C.S. (Coord.). (1999). Urbanismo no Brasil - 1895-1965. São Paulo: Studio Nobel; FUPAM.

LIMA, J.F. (19--?). CTRS: Centro de Tecnologia da rede Sarah. [S.I.]: Sarah Letras.

LOMARDO, L.L.B. (1997). Arquitetura e energia. Finestra Brasil, ano 2, n.8, p.96-98.

MACEDO, C.C. (2002). Análise do desempenho térmico e luminoso de sistemas de iluminação natural que utilizam a luz direta do sol. Dissertação (Mestrado) - Universidade Federal de Santa Catarina, Florianópolis, 2002.

MANGE, E.R.C. (1956). A Função abrigo em arquitetura. São Paulo: Atena. Originalmente apresentado como tese (cátedra) na Faculdade de Arquitetura da Universidade de São Paulo.

. (1963). Planejamento em Urubupungá. Tese (Livre Docência) Escola Politécnica, Universidade de São Paulo, São Paulo, 1963.

MANGE, E.R.C. et al. (1959). Escola de Engenharia de São Carlos. Acrópole, São Paulo, v.21, n.249, p.324-329, jul./ago.

MASCARÓ, J.L. (1980). Consumo de energia e construção de edifícios. São Paulo: SECOVI.

MASCARÓ, J.L.; MASCARÓ, L.E.R. (Coord.). (1992). Incidência das variáveis projetivas e de construção no consumo energético dos edifícios. Porto Alegre: PROPAR.

MASCARÓ, L.E.R. (1985). Energia na edificação: estratégia para minimizar seu consumo. São Paulo: Projeto.

MASCARÓ, L.E.R.; VIANNA, N.S. (1980). Iluminação natural nos edifícios. Porto Alegre: PROPAR.

MCARDLE, W.D.; KATCH, F.I.; KATCH, V.L. (1985). Diferenças individuais e mensurações das capacidades energéticas. In: Fisiologia do 
exercício - energia, nutrição e desempenho humano. Rio de Janeiro: Guanabara. p.122-139.

MEMORIAL sobre a reestruturação da Universidade de São Paulo. (1968). São Paulo: USP.

MONTERO, J.I.P. (2006). Ventilação e iluminação naturais na obra de João Filgueiras Lima, Lelé: estudo dos hospitais da rede Sarah Kubitschek Fortaleza e Rio de Janeiro. Dissertação (Mestrado) - Escola de Engenharia de São Carlos, Universidade de São Paulo, São Carlos, 2006.

NEVES, L.O. (2006). Arquitetura bioclimática e a obra de Severiano Porto: estratégias de ventilação natural. Dissertação (Mestrado) - Escola de Engenharia de São Carlos, Universidade de São Paulo, São Carlos, 2006.

NOGUEIRA, C.J.A.N.; DURANTE, L.C.; NOGUEIRA, J.S. (2005). Conforto térmico na escola pública em Cuiabá-MT: estudo de caso. Revista Eletrônica do Mestrado em Educação Ambiental, Rio Grande, v.14, jan./jun.

NOSELLA, P.; BUFFA, E. (2000). Escola de Engenharia de São Carlos: os primeiros tempos - 1948-1971. São Carlos: EDUFSCAR.

OLGYAY, V. (1998). Arquitectura y clima. Barcelona: Gustavo Gili.

ORNSTEIN, S. (1992). Avaliação pós-ocupação do ambiente construído. São Paulo: EDUSP.

ÖZISIK, M.N. (1990). Transferência de calor: um texto básico. Tradução de Luiz de Oliveira. Rio de Janeiro: Guanabara Koogan.

PERROT, M. (1991). Maneiras de morar. In: HISTÓRIA da vida privada. São Paulo: Companhia das Letras. v.4, p.307-323.

PIETROBON, C.E. (1999). Luz e calor no ambiente construído escolar e o sombreamento arbóreo: conflito ou compromisso com a conservação de energia. Tese (Doutorado) - Universidade Federal de Santa Catarina, Florianópolis, 1999.

PORTO, S. (1988). Severiano Porto: abrigo natural [Entrevista]. Arquitetura \& Urbanismo, São Paulo, ano 15, n.81, p.24-25, dez./jan.

RAMON, F. (1980). Ropa, sudor y arquitectures. Madrid: Blume.

RECAMÁN, L. (2005). Lelé e a arquitetura moderna brasileira. Disponível em:<http://brazil-brasil.com.htm>. Acesso em: 10 jun. 2005.

RIVERO, R. (1985). Arquitetura e clima: acondicionamento térmico natural. Porto Alegre: D.C.Luzzatto. 
ROMERO, M.A. (1987). Arquitetura, comportamento e energia. Tese (Livre-Docência) - Faculdade de Arquitetura e Urbanismo, Universidade de São Paulo, São Paulo, 1987.

. (1991). Conservação de energia e o projeto de arquitetura: uma análise geral. Sinopses, São Paulo, n.16, p.6-9, dez.

(1987). Arquitetura, comportamento e energia. Tese (LivreDocência) - Faculdade de Arquitetura e Urbanismo, Universidade de São Paulo, São Paulo, 1987.

. (2000). A Arquitetura, o conforto ambiental e o comportamento dos usuários. Sinopses, São Paulo, n.34, p.31-49, dez.

(2003a). Índices de conforto térmico - parte I. Climatização, São Paulo, v.3, n.33, p.38-41, maio.

(2003b). Índices de conforto térmico - parte II. Climatização, São Paulo, v.3, n.34, p.18-22, jun.

(2003c). Índices de conforto térmico - parte III. Climatização, São Paulo, v.3, n.35, p.22-29, jul.

. (2003d). Índices de conforto térmico - parte IV. Climatização, São Paulo, v.3, n.36, p.20-23, ago.

(2003e). Índices de conforto térmico - parte V. Climatização, São Paulo, v.4, n.37, p.32-38, set.

ROMERO, M.A.; AZEVEDO, J.H. (1997). Avaliação comportamental e energética do edifício da FAUUSP. Cadernos Técnicos AUT, São Paulo, n.3, p.29-50.

RORIZ, M. 1996). Conforto térmico em edificações: um modelo matemático e uma aplicação. Tese (Doutorado) - Faculdade de Arquitetura e Urbanismo, Universidade de São Paulo, São Paulo, 1996.

. (2001). Higiene do trabalho: temperatura. São Carlos: UFSCar. Apostila do curso de especialização Engenharia de Segurança do Trabalho.

(2004). Conforto lumínico no ambiente construído. São Carlos:

UFSCar. Apostila da disciplina Conforto Térmico e Lumínico no Ambiente Construído.

ROVO, M.K.I.; ROVO, B.S.O. (2004). Por um regionalismo eco-eficiente: a obra de Severiano Mário Porto no Amazonas. Disponível em:<http://www.acnice.fretabscamuspresentaconstrucchroniq>. Acesso em: 12 jun. 2005.

RUAS, A.C. (1999). Avaliação de conforto térmico - contribuição à aplicação prática das normas internacionais. Dissertação (Mestrado) - 
Faculdade de Engenharia Civil, Universidade Estadual de Campinas, Campinas, 1999.

(2002). Sistematização da avaliação de conforto térmico em ambientes edificados e sua aplicação num software. Tese (Doutorado) Faculdade de Engenharia Civil, Universidade Estadual de Campinas, Campinas, 2002.

SÁ, P. (1936). Estudos sobre conforto thermico no Brasil: o thermometro resultante de Missenard. Rio de Janeiro: Instituto Nacional de Technologia.

(1954). Iluminamento natural - ensaios para sua previsão nos edifícios da Cidade Universitária. Rio de Janeiro: Escritório Técnico da Cidade Universitária.

SANTOS, J.C.P. (2002). Desempenho térmico e visual de elementos transparentes frente à radiação solar. Tese (Doutorado) - Escola de Engenharia de São Carlos, Universidade de São Paulo, São Carlos, 2002.

SARDEIRO, P.S. (2002). Estudo das janelas laterais e a iluminação natural. Dissertação (Mestrado) - Escola de Engenharia de São Carlos, Universidade de São Paulo, São Carlos, 2002.

SCARAZZATO, P.S. (1988). Investigação sobre critérios para determinação e medição dos níveis de conforto térmico. Dissertação (Mestrado) - Faculdade de Arquitetura e Urbanismo, Universidade de São Paulo, São Paulo, 1988.

(1995). Conceito de dia típico de projeto aplicado à iluminação natural: dados referenciais para localidades brasileiras. Tese (Doutorado) Faculdade de Arquitetura e Urbanismo, Universidade de São Paulo, São Paulo, 1995.

SEGAWA, H. (1997). Arquiteturas no Brasil 1900-1990. São Paulo: EDUSP. . (1998). Hélio Duarte. Arquitetura \& Urbanismo, São Paulo, ano 14, n.80, p.57-65, out./nov.

(2001). Clave de sol. In: ENCONTRO NACIONAL DE CONFORTO NO AMBIENTE CONSTRUÍDO, 6./ ENCONTRO LATINO-AMERICANO DE CONFORTO NO AMBIENTE CONSTRUÍDO, 3., 2001, São Pedro. Anais... [S.I.]: ANTAC. 1 CD-ROM.

SENA, C.B. (2004). Análise comparativa entre o método de Mahoney tradicional e o método de Mahoney nebuloso para caracterização do clima no projeto arquitetônico. Dissertação (Mestrado) - Escola Politécnica, Universidade de São Paulo, São Paulo, 2004. 
SHALDERS NETO, A. (2003). Regulamentação de desempenho térmico e energético de edificações. Dissertação (Mestrado) - Instituto de Eletrotécnica e Energia, Universidade de São Paulo, São Paulo, 2003.

SICHIERI, E.P. (2001). Controle energético de edificações através de superfícies transparentes. Tese (Livre-Docência) - Escola de Engenharia de São Carlos, Universidade de São Paulo, São Carlos, 2001.

SISTEMAS naturais de ventilação e iluminação: João Filgueiras Lima - Lelé Disponível em:<http://www.arq.ufsc.br/ labcon/arq5661/trabalhos_2001 2/ventilacao_Lele/principal.htm>. Acesso em: 10 jun. 2005.

SZABO, L.P. (2002). Em busca de uma luz paulistana: a concepção de luz natural no projeto de arquitetos da cidade de São Paulo. Tese (Doutorado) Faculdade de Arquitetura e Urbanismo, Universidade de São Paulo, São Paulo, 2002.

TOLEDO, E. (1999). Ventilação natural das habitações. Maceió: EDUFAL.

TOLENTINO, E. (1967). Estudo crítico sobre o clima da região de São

Carlos. São Carlos: [s.n.]. (Concurso Municipal de Monografias, 1967).

VECCHIA, F.A.S. (1989). As Condicionantes termo-energéticas das edificações: São Carlos como estudo de caso. Dissertação (Mestrado) Escola de Engenharia de São Carlos, Universidade de São Paulo, São Carlos, 1989.

VIANNA, N.S.; GONÇALVES, J.C.S. (2001). Iluminação e arquitetura. São Paulo: Virtus; Universidade do Grande ABC.

XAVIER, A.A.P. (1999). Condições de conforto térmico para estudantes de 2o grau na região de Florianópolis. Dissertação (Mestrado) - Universidade Federal de Santa Catarina, Florianópolis, 1999.

XAVIER, A.; LEMOS, C.; CORONA, E. (1983). Arquitetura moderna paulistana. São Paulo: Pini. 


$$
1
$$


APÊNDICE A - normais climatológicas: São Carlos 
As tabelas abaixo apresentam dados de temperatura média, temperatura máxima, temperatura mínima, precipitação total, evaporação total, umidade relativa, nebulosidade e pressão atmosférica referentes à cidade de São Carlos no período de 1961 a 1990. Esses dados foram retirados da publicação Normais Climatológicas (1961-1990) realizada pelo Departamento Nacional de Meteorologia do Ministério da Agricultura e Reforma Agrária.

Normais Climatológicas de São Carlos (1961-1990)

\begin{tabular}{|c|c|c|c|c|}
\hline Meses & $\begin{array}{c}\text { Temperatura } \\
\text { Média }\left({ }^{\circ} \mathrm{C}\right)\end{array}$ & $\begin{array}{c}\text { Temperatura } \\
\text { Máxima }\left({ }^{\circ} \mathrm{C}\right)\end{array}$ & $\begin{array}{c}\text { Temperatura } \\
\text { Mínima }\left({ }^{\circ} \mathrm{C}\right)\end{array}$ & $\begin{array}{c}\text { Precipitação } \\
\text { Total }(\mathrm{mm})\end{array}$ \\
\hline JAN & 21.6 & 26.8 & 17.5 & 248.7 \\
\hline FEV & 21.9 & 27.2 & 17.7 & 191.4 \\
\hline MAR & 21.7 & 27.0 & 17.2 & 167.3 \\
\hline ABR & 20.2 & 25.7 & 15.5 & 73.2 \\
\hline MAI & 18.1 & 23.6 & 13.2 & 61.6 \\
\hline JUN & 16.7 & 22.7 & 12.0 & 40.4 \\
\hline JUL & 16.0 & 22.1 & 11.4 & 30.8 \\
\hline AGO & 17.8 & 24.3 & 12.5 & 30.9 \\
\hline SET & 19.6 & 25.0 & 14.2 & 65.0 \\
\hline OUT & 19.7 & 24.7 & 14.7 & 157.8 \\
\hline NOV & 21.1 & 25.7 & 16.0 & 160.8 \\
\hline DEZ & 21.4 & 25.2 & 17.2 & 267.2 \\
\hline ANO & 19.6 & 25.0 & 14.9 & 1495.1 \\
\hline
\end{tabular}

Normais Climatológicas de São Carlos (1961-1990)

\begin{tabular}{|c|c|c|c|c|}
\hline Meses & $\begin{array}{c}\text { Evaporação } \\
\text { Total }(\mathrm{mm})\end{array}$ & $\begin{array}{c}\text { Umidade } \\
\text { Relativa (\%) }\end{array}$ & $\begin{array}{c}\text { Nebulosidade } \\
(0-10)\end{array}$ & $\begin{array}{c}\text { Pressão } \\
\text { Atm. (hPa) }\end{array}$ \\
\hline JAN & 97.9 & 76.0 & 7.1 & 885.7 \\
\hline FEV & 93.7 & 75.0 & 6.8 & 886.3 \\
\hline MAR & 108.7 & 73.0 & 6.0 & 886.7 \\
\hline ABR & 110.4 & 68.0 & 4.9 & 887.8 \\
\hline MAI & 110.3 & 67.0 & 4.4 & 889.4 \\
\hline JUN & 109.1 & 66.0 & 4.1 & 890.3 \\
\hline JUL & 132.6 & 61.0 & 3.6 & 860.4 \\
\hline AGO & 173.6 & 54.0 & 3.7 & 859.1 \\
\hline SET & 175.5 & 58.0 & 4.6 & 888.5 \\
\hline OUT & 151.6 & 80.0 & 7.1 & 886.8 \\
\hline NOV & 132.3 & 67.0 & 6.0 & 885.6 \\
\hline DEZ & 102.1 & 73.0 & 6.8 & 885.3 \\
\hline ANO & 1497.9 & 68.0 & 5.4 & 882.7 \\
\hline
\end{tabular}




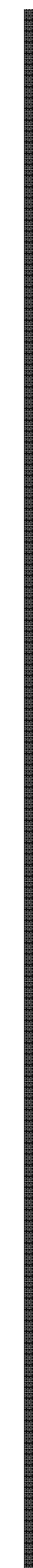

Modelo do questionário aplicado 
APÊNDICE B - modelo do questionário aplicado 
UNIVERSIDADE DE SÃO PAULO

ESCOLA DE ENGENHARIA DE SÃO CARLOS

DEPARTAMENTO DE ARQUITETURA E URBANISMO

Você está sendo convidado para participar de uma pesquisa científica realizada nesta escola, referente ao conforto térmico e visual do prédio em que você trabalha. A sua participação é muito importante. Obrigada!

QUESTIONÁRIO - avaliação pós-ocupação: conforto ambiental

Data:

Pavimento:

Sala:

\section{Avaliador:}

1. Atividade metabólica desenvolvida pelo entrevistado:

$$
\text { Leve Média Pesada }
$$

2. Atividade visual desenvolvida pelo entrevistado:
Escritório
Desenho
Outra

\section{Avaliado:}

- Idade: anos

- Sexo: Masculino Feminino

- Tempo que trabalha no prédio: anos

1. Como você qualifica a temperatura em sua sala de trabalho no verão?

Muito quente

Quente

Levemente quente 
Nem quente, nem frio

Levemente fria

Fria

Muito fria

2. Como você qualifica a temperatura em sua sala de trabalho no inverno?

Muito quente

Quente

Levemente quente

Nem quente, nem frio

Levemente fria

Fria

Muito fria

3. Com qual freqüência você necessita acender as lâmpadas durante o expediente de trabalho no verão?

Diariamente

Algumas vezes

Nunca

Em caso de necessidade em acender as lâmpadas, em qual período do dia isso é feito?

\author{
Manhã \\ Tarde \\ Os dois períodos
}

4. Com qual freqüência você necessita acender as lâmpadas durante o expediente de trabalho no inverno?

Diariamente 
Algumas vezes

Nunca

Em caso de necessidade em acender as lâmpadas, em qual período do dia isso é feito?

Manhã

Tarde

Os dois períodos

5. Como você qualifica a iluminação na sua mesa de trabalho com as lâmpadas desligadas?

Ótima

Boa

Razoável

Precária

Péssima

6. Em relação à transparência ocasionada pelas grandes áreas envidraçadas das fachadas, qual sua sensação?
Agradável
Indiferente
Desagradável
7. Comentários. 
<smiles>[CH]C</smiles> 
APÊNDICE C - tabulação de dados - variáveis ambientais

Tabulação de dados - resultados das medições das variáveis ambientais

- Período 1

Assistência Administrativa: 14 a 17 de novembro de 2006.

Ante-sala da Congregação: 21 a 24 de novembro de 2006.

Índice de vestimenta: 0.49 clo

Atividade: $65 \mathrm{~W} / \mathrm{m}^{2}$

- Período 2

Assistência Administrativa: 05 a 08 de março de 2007.

Ante-sala da Congregação: 12 a 15 de março de 2007.

Índice de vestimenta: $0.49 \mathrm{clo}$

Atividade: $65 \mathrm{~W} / \mathrm{m}^{2}$

- Período 3

Assistência Administrativa: 11 a 14 de junho de 2007.

Ante-sala da Congregação: 31 de maio a 03 de junho de 2007.

Índice de vestimenta: 0.86 clo

Atividade: $65 \mathrm{~W} / \mathrm{m}^{2}$

- Período 4

Assistência Administrativa: 26 a 29 de junho de 2007.

Ante-sala da Congregação: 05 a 08 de julho de 2007.

Índice de vestimenta: 0.86 clo

Atividade: $65 \mathrm{~W} / \mathrm{m}^{2}$ 
Ambiente: Assistência Administrativa

Período 1: 14 a 17 de novembro de 2006

\begin{tabular}{|c|c|c|c|c|c|c|c|c|c|c|}
\hline Data & Hora & Temp. int. & Temp. ext. & Vel. int. & Vel. ext. & UR int. & UR ext. & $\begin{array}{c}\text { Temp. } \\
\text { Globo } \\
\text { int. }\end{array}$ & PMV & PPD \\
\hline $14 / 11 / 2006$ & $8: 00$ & 20.31 & 20.18 & 0.1 & 1.348 & 65.24 & 64.49 & 19.58 & -1.68963 & 61.19552 \\
\hline $14 / 11 / 2006$ & $8: 30$ & 20.95 & 21.15 & 0.16 & 1.716 & 64.51 & 58.67 & 20.23 & -1.71232 & 62.40999 \\
\hline $14 / 11 / 2006$ & 9:00 & 21.9 & 22.16 & 0.17 & 1.5 & 61.92 & 56.3 & 21.1 & -1.44809 & 48.09036 \\
\hline $14 / 11 / 2006$ & 9:30 & 22.23 & 22.7 & 0.21 & 2.016 & 59.11 & 55.1 & 21.51 & -1.46326 & 48.90878 \\
\hline $14 / 11 / 2006$ & $10: 00$ & 22.48 & 23.15 & 0.23 & 1.912 & 58.64 & 53.93 & 21.79 & -1.42652 & 46.93026 \\
\hline $14 / 11 / 2006$ & $10: 30$ & 22.54 & 23.41 & 0.24 & 1.923 & 59.53 & 53.82 & 21.95 & -1.41077 & 46.08677 \\
\hline $14 / 11 / 2006$ & $11: 00$ & 22.8 & 23.84 & 0.26 & 1.523 & 59.04 & 52.67 & 22.13 & -1.37724 & 44.30268 \\
\hline $14 / 11 / 2006$ & $11: 30$ & 23.43 & 23.84 & 0.23 & 1.418 & 58.1 & 52.53 & 22.66 & -1.09488 & 30.28029 \\
\hline $14 / 11 / 2006$ & $12: 00$ & 23.69 & 23.95 & 0.26 & 1.589 & 57.38 & 52.11 & 23 & -1.06003 & 28.71431 \\
\hline $14 / 11 / 2006$ & $12: 30$ & 23.91 & 24.94 & 0.14 & 1.386 & 56.86 & 49.59 & 23 & -0.70615 & 15.48865 \\
\hline $14 / 11 / 2006$ & $13: 00$ & 23.94 & 25.45 & 0.15 & 1.257 & 56.53 & 48.06 & 23.04 & -0.72834 & 16.16512 \\
\hline $14 / 11 / 2006$ & $13: 30$ & 24.06 & 24.92 & 0.15 & 1.014 & 56.33 & 48.86 & 23.18 & -0.68556 & 14.88033 \\
\hline $14 / 11 / 2006$ & $14: 00$ & 24.23 & 26.28 & 0.29 & 1.027 & 55.62 & 44.49 & 23.45 & -0.9406 & 23.68646 \\
\hline $14 / 11 / 2006$ & $14: 30$ & 24.58 & 26.84 & 0.16 & 0.861 & 54.56 & 42.17 & 23.65 & -0.55474 & 11.44314 \\
\hline $14 / 11 / 2006$ & $15: 00$ & 24.94 & 26.34 & 0.24 & 1.019 & 52.88 & 40.9 & 24.16 & -0.60043 & 12.55919 \\
\hline $14 / 11 / 2006$ & $15: 30$ & 25.22 & 25.98 & 0.32 & 1.483 & 51.93 & 45.2 & 24.43 & -0.64023 & 13.60519 \\
\hline $14 / 11 / 2006$ & $16: 00$ & 25.35 & 26.61 & 0.25 & 1.241 & 51.56 & 44.35 & 24.55 & -0.48007 & 9.813707 \\
\hline $14 / 11 / 2006$ & $16: 30$ & 24.99 & 26.36 & 0.28 & 1.111 & 52.32 & 42.58 & 24.26 & -0.6524 & 13.93865 \\
\hline $14 / 11 / 2006$ & 17:00 & 25.12 & 26.35 & 0.34 & 0.855 & 52.82 & 41.82 & 24.45 & -0.68551 & 14.87872 \\
\hline $14 / 11 / 2006$ & $17: 30$ & 24.96 & 25.84 & 0.51 & 1.364 & 50.76 & 45.12 & 24.39 & -0.96418 & 24.63606 \\
\hline $14 / 11 / 2006$ & $18: 00$ & 24.9 & 24.37 & 0.26 & 1.132 & 50.51 & 47.6 & 24.17 & -0.66392 & 14.26055 \\
\hline $15 / 11 / 2006$ & $8: 00$ & 21.87 & 22.09 & 0.07 & 1.177 & 62.08 & 64.76 & 20.99 & -1.19266 & 34.88942 \\
\hline $15 / 11 / 2006$ & $8: 30$ & 22.18 & 23.03 & 0.09 & 1.111 & 61.96 & 62.11 & 21.31 & -1.08547 & 29.85313 \\
\hline $15 / 11 / 2006$ & 9:00 & 22.58 & 23.54 & 0.11 & 1.048 & 61.41 & 60.27 & 21.6 & -1.01675 & 26.8304 \\
\hline $15 / 11 / 2006$ & $9: 30$ & 22.81 & 24.29 & 0.13 & 1.065 & 61.5 & 58.92 & 21.87 & -1.0156 & 26.78096 \\
\hline $15 / 11 / 2006$ & $10: 00$ & 23 & 24.66 & 0.16 & 0.996 & 61.4 & 57.21 & 22.05 & -1.05806 & 28.62717 \\
\hline $15 / 11 / 2006$ & $10: 30$ & 23.13 & 25.58 & 0.13 & 1.195 & 61.41 & 52.13 & 22.21 & -0.90561 & 22.31857 \\
\hline $15 / 11 / 2006$ & $11: 00$ & 23.35 & 26.61 & 0.14 & 1.27 & 61.27 & 49.26 & 22.39 & -0.8738 & 21.11761 \\
\hline $15 / 11 / 2006$ & $11: 30$ & 23.57 & 26.78 & 0.15 & 1.337 & 60.8 & 48.56 & 22.59 & -0.8377 & 19.80536 \\
\hline $15 / 11 / 2006$ & $12: 00$ & 23.9 & 26.47 & 0.13 & 1.24 & 59.85 & 48.71 & 22.93 & -0.6642 & 14.26827 \\
\hline $15 / 11 / 2006$ & $12: 30$ & 24.13 & 26.4 & 0.16 & 1.02 & 59.04 & 47.02 & 23.21 & -0.67759 & 14.64962 \\
\hline $15 / 11 / 2006$ & $13: 00$ & 24.29 & 27.15 & 0.16 & 1.252 & 58.73 & 44.53 & 23.28 & -0.63722 & 13.52367 \\
\hline $15 / 11 / 2006$ & $13: 30$ & 24.34 & 28.49 & 0.14 & 1.783 & 58.26 & 40.16 & 23.36 & -0.55992 & 11.56505 \\
\hline $15 / 11 / 2006$ & 14:00 & 24.56 & 28.97 & 0.14 & 1.529 & 57.69 & 37.98 & 23.46 & -0.50665 & 10.36605 \\
\hline $15 / 11 / 2006$ & $14: 30$ & 24.9 & 29.3 & 0.12 & 1.696 & 56.25 & 34.2 & 23.87 & -0.32944 & 7.256918 \\
\hline $15 / 11 / 2006$ & $15: 00$ & 25.11 & 29.53 & 0.12 & 1.797 & 55.31 & 34.57 & 24.07 & -0.26761 & 6.487013 \\
\hline $15 / 11 / 2006$ & $15: 30$ & 25.32 & 30.05 & 0.16 & 1.407 & 53.68 & 32.65 & 24.29 & -0.31841 & 7.107706 \\
\hline $15 / 11 / 2006$ & $16: 00$ & 25.39 & 29.26 & 0.13 & 1.637 & 53.01 & 33.75 & 24.41 & -0.21171 & 5.929613 \\
\hline $15 / 11 / 2006$ & $16: 30$ & 25.44 & 28.59 & 0.14 & 0.585 & 52.43 & 34.64 & 24.43 & -0.23157 & 6.112645 \\
\hline $15 / 11 / 2006$ & $17: 00$ & 25.44 & 27.77 & 0.17 & 0.177 & 52.22 & 33.76 & 24.43 & -0.30885 & 6.982644 \\
\hline $15 / 11 / 2006$ & $17: 30$ & 25.33 & 27.47 & 0.15 & 0.702 & 52.34 & 33.29 & 24.34 & -0.29368 & 6.791947 \\
\hline $15 / 11 / 2006$ & $18: 00$ & 24.99 & 26.88 & 0.15 & 0.106 & 52.91 & 35.04 & 24.06 & -0.3977 & 8.295279 \\
\hline $16 / 11 / 2006$ & 8:00 & 23.35 & 24.5 & 0.19 & 1.415 & 64.12 & 61.22 & 22.48 & -0.99464 & 25.89447 \\
\hline $16 / 11 / 2006$ & $8: 30$ & 23.58 & 25.27 & 0.41 & 1.198 & 67.28 & 59.96 & 22.89 & -1.29863 & 40.19805 \\
\hline $16 / 11 / 2006$ & 9:00 & 23.89 & 25.99 & 0.42 & 1.474 & 67.51 & 57.28 & 23.26 & -1.17829 & 34.19358 \\
\hline $16 / 11 / 2006$ & $9: 30$ & 24.34 & 26.71 & 0.47 & 1.958 & 67.07 & 55.19 & 23.73 & -1.06035 & 28.72855 \\
\hline $16 / 11 / 2006$ & $10: 00$ & 25.02 & 27.24 & 0.48 & 2.094 & 64.95 & 54.04 & 24.35 & -0.81301 & 18.93933 \\
\hline
\end{tabular}




\begin{tabular}{|c|c|c|c|c|c|c|c|c|c|c|}
\hline $16 / 11 / 2006$ & $10: 30$ & 25.76 & 27.74 & 0.66 & 1.812 & 62.43 & 53.77 & 25.09 & -0.68332 & 14.81518 \\
\hline $16 / 11 / 2006$ & $11: 00$ & 25.97 & 28.41 & 0.48 & 1.982 & 62.41 & 50.66 & 25.47 & -0.41505 & 8.590886 \\
\hline 16/11/2006 & $11: 30$ & 26.73 & 29.29 & 0.44 & 1.84 & 61.37 & 47.57 & 25.97 & -0.10213 & 5.216032 \\
\hline 16/11/2006 & $12: 00$ & 27.18 & 29.25 & 0.44 & 1.593 & 57.65 & 46.25 & 26.55 & 0.069397 & 5.099715 \\
\hline 16/11/2006 & $12: 30$ & 27.26 & 28.18 & 0.18 & 1.467 & 57.34 & 48.92 & 26.3 & 0.368292 & 7.823581 \\
\hline $16 / 11 / 2006$ & $13: 00$ & 27.15 & 27.96 & 0.17 & 1.193 & 57.28 & 49.73 & 26.17 & 0.343188 & 7.450107 \\
\hline $16 / 11 / 2006$ & $13: 30$ & 26.86 & 28.11 & 0.15 & 1.012 & 57.82 & 49.6 & 25.84 & 0.278383 & 6.609567 \\
\hline $16 / 11 / 2006$ & $14: 00$ & 27 & 27.05 & 0.32 & 1.136 & 57.07 & 55.26 & 26.14 & 0.083652 & 5.144901 \\
\hline $16 / 11 / 2006$ & $14: 30$ & 27.15 & 26.91 & 0.33 & 0.142 & 57.26 & 57.4 & 26.36 & 0.142357 & 5.419883 \\
\hline $16 / 11 / 2006$ & $15: 00$ & 26.73 & 27.95 & 0.32 & 0.08 & 61.33 & 54.85 & 26.11 & 0.046024 & 5.043853 \\
\hline 16/11/2006 & $15: 30$ & 27.26 & 28.79 & 0.19 & 0.299 & 58.93 & 48.03 & 26.21 & 0.351512 & 7.570963 \\
\hline $16 / 11 / 2006$ & $16: 00$ & 27.43 & 28.75 & 0.19 & 0.645 & 58.28 & 46.05 & 26.47 & 0.421262 & 8.699877 \\
\hline $16 / 11 / 2006$ & $16: 30$ & 27.69 & 26.82 & 0.22 & 0.548 & 57.14 & 56.68 & 26.73 & 0.462237 & 9.460254 \\
\hline $16 / 11 / 2006$ & $17: 00$ & 27.59 & 28.47 & 0.4 & 0.428 & 54.73 & 47.93 & 26.73 & 0.21705 & 5.977226 \\
\hline $16 / 11 / 2006$ & $17: 30$ & 27.53 & 28.96 & 0.16 & 0.729 & 59.73 & 45.09 & 26.55 & 0.518552 & 10.62331 \\
\hline $16 / 11 / 2006$ & $18: 00$ & 27.58 & 29.24 & 0.23 & 0.425 & 58.82 & 44.72 & 26.64 & 0.424701 & 8.760921 \\
\hline $17 / 11 / 2006$ & $8: 00$ & 24.68 & 24.82 & 0.35 & 1.102 & 64.43 & 60.96 & 24.01 & -0.78683 & 18.04882 \\
\hline 17/11/2006 & $8: 30$ & 24.79 & 26.33 & 0.38 & 1.452 & 64.83 & 56.34 & 24.18 & -0.77571 & 17.67949 \\
\hline $17 / 11 / 2006$ & $9: 00$ & 25.11 & 27.53 & 0.51 & 1.329 & 64.54 & 51.42 & 24.55 & -0.79713 & 18.39555 \\
\hline $17 / 11 / 2006$ & $9: 30$ & 25.77 & 27.96 & 0.46 & 1.986 & 61.69 & 48.39 & 25.18 & -0.49484 & 10.11692 \\
\hline $17 / 11 / 2006$ & $10: 00$ & 26.45 & 28.38 & 0.47 & 2.121 & 57.54 & 47.88 & 25.84 & -0.25887 & 6.39119 \\
\hline $17 / 11 / 2006$ & $10: 30$ & 26.93 & 29 & 0.57 & 1.799 & 56.3 & 46.01 & 26.36 & -0.14635 & 5.443808 \\
\hline 17/11/2006 & $11: 00$ & 27.44 & 29.51 & 0.4 & 1.587 & 54.89 & 45.63 & 26.84 & 0.192274 & 5.76653 \\
\hline 17/11/2006 & $11: 30$ & 27.79 & 29.86 & 0.51 & 1.53 & 53.01 & 44.68 & 27.2 & 0.232011 & 6.116905 \\
\hline $17 / 11 / 2006$ & $12: 00$ & 28.26 & 30.94 & 0.48 & 1.533 & 53.47 & 40.74 & 27.62 & 0.448031 & 9.188456 \\
\hline $17 / 11 / 2006$ & $12: 30$ & 28.24 & 31.65 & 0.17 & 1.414 & 53.98 & 36.64 & 27.34 & 0.717488 & 15.83167 \\
\hline $17 / 11 / 2006$ & $13: 00$ & 28.61 & 30.77 & 0.17 & 0.994 & 52.8 & 37.01 & 27.54 & 0.814109 & 18.97727 \\
\hline $17 / 11 / 2006$ & $13: 30$ & 28.76 & 30.33 & 0.18 & 1.447 & 51.56 & 40.28 & 27.78 & 0.856669 & 20.48822 \\
\hline 17/11/2006 & $14: 00$ & 29.06 & 32.03 & 0.35 & 1.585 & 47.25 & 35.92 & 28.27 & 0.79056 & 18.17394 \\
\hline $17 / 11 / 2006$ & $14: 30$ & 29.44 & 31.47 & 0.46 & 1.855 & 47.85 & 36.62 & 28.58 & 0.870577 & 20.9983 \\
\hline $17 / 11 / 2006$ & $15: 00$ & 30.15 & 31.71 & 0.32 & 1.742 & 45.52 & 36.75 & 29.38 & 1.228164 & 36.63505 \\
\hline $17 / 11 / 2006$ & $15: 30$ & 30.31 & 32.66 & 0.35 & 1.342 & 43.97 & 33.51 & 29.56 & 1.261437 & 38.30199 \\
\hline 17/11/2006 & $16: 00$ & 30.52 & 32.49 & 0.32 & 1.33 & 44.01 & 33.19 & 29.84 & 1.371282 & 43.98757 \\
\hline $17 / 11 / 2006$ & $16: 30$ & 30.71 & 31.59 & 0.32 & 1.241 & 43.12 & 34.44 & 29.93 & 1.422694 & 46.72495 \\
\hline $17 / 11 / 2006$ & $17: 00$ & 30.62 & 31.47 & 0.42 & 1.169 & 42.33 & 34.67 & 29.93 & 1.344338 & 42.57012 \\
\hline $17 / 11 / 2006$ & $17: 30$ & 30.4 & 31.17 & 0.31 & 0.793 & 42.65 & 35.38 & 29.75 & 1.320184 & 41.31114 \\
\hline $17 / 11 / 2006$ & $18: 00$ & 30.18 & 30.65 & 0.41 & 0.497 & 43.03 & 37.51 & 29.51 & 1.179144 & 34.23457 \\
\hline
\end{tabular}


Ambiente: Assistência Administrativa

Período 2: 05 a 08 de março de 2007

\begin{tabular}{|c|c|c|c|c|c|c|c|c|c|c|}
\hline Data & Hora & Temp. int. & Temp. ext. & Vel. int. & Vel. ext. & UR int. & UR ext. & $\begin{array}{l}\text { Temp. } \\
\text { Globo int. }\end{array}$ & PMV & PPD \\
\hline $5 / 3 / 2007$ & 8:00 & 24.69 & 23.86 & 0.41 & 1.027 & 62.65 & 61.32 & 24.77 & -0.78289 & 17.91728 \\
\hline $5 / 3 / 2007$ & $8: 30$ & 25.58 & 24.66 & 0.41 & 1.37 & 60.18 & 59.31 & 25.08 & -0.51655 & 10.5795 \\
\hline $5 / 3 / 2007$ & 9:00 & 26.07 & 25.39 & 0.42 & 1.472 & 58.48 & 57.37 & 25.56 & -0.34341 & 7.453309 \\
\hline $5 / 3 / 2007$ & $9: 30$ & 26.58 & 26.11 & 0.47 & 1.505 & 58.23 & 55.85 & 26.07 & -0.18634 & 5.719885 \\
\hline $5 / 3 / 2007$ & $10: 00$ & 26.88 & 26.55 & 0.62 & 1.739 & 56.54 & 54.44 & 26.47 & -0.18203 & 5.686948 \\
\hline $5 / 3 / 2007$ & $10: 30$ & 27.56 & 27.32 & 0.4 & 1.427 & 54.85 & 51.8 & 26.99 & 0.244664 & 6.242365 \\
\hline $5 / 3 / 2007$ & 11:00 & 27.83 & 27.81 & 0.4 & 1.558 & 53.69 & 49.92 & 27.36 & 0.3576 & 7.661234 \\
\hline $5 / 3 / 2007$ & $11: 30$ & 28.42 & 28.14 & 0.4 & 1.417 & 52.61 & 49.2 & 27.85 & 0.574422 & 11.91274 \\
\hline $5 / 3 / 2007$ & $12: 00$ & 28.81 & 28.63 & 0.36 & 1.36 & 51.29 & 49.45 & 28.33 & 0.763708 & 17.28669 \\
\hline $5 / 3 / 2007$ & $12: 30$ & 29.2 & 29.06 & 0.2 & 1.272 & 51.48 & 48.48 & 28.49 & 1.033158 & 27.53644 \\
\hline $5 / 3 / 2007$ & $13: 00$ & 29.4 & 29.49 & 0.18 & 0.875 & 51.31 & 43.53 & 28.61 & 1.11549 & 31.22608 \\
\hline $5 / 3 / 2007$ & $13: 30$ & 29.47 & 30.28 & 0.2 & 1.145 & 51.04 & 40.68 & 28.73 & 1.123937 & 31.6178 \\
\hline $5 / 3 / 2007$ & $14: 00$ & 29.26 & 30.38 & 0.3 & 1.041 & 46.5 & 39.15 & 28.7 & 0.933559 & 23.40732 \\
\hline $5 / 3 / 2007$ & $14: 30$ & 29.25 & 30.8 & 0.31 & 0.695 & 47.13 & 38.26 & 28.64 & 0.920453 & 22.89282 \\
\hline $5 / 3 / 2007$ & $15: 00$ & 28.94 & 29.55 & 0.4 & 0.317 & 47.22 & 40.7 & 28.43 & 0.743817 & 16.64927 \\
\hline $5 / 3 / 2007$ & $15: 30$ & 29.32 & 29.98 & 0.59 & 0.266 & 43.35 & 39.34 & 28.76 & 0.749883 & 16.84187 \\
\hline $5 / 3 / 2007$ & $16: 00$ & 29.47 & 31.43 & 0.42 & 0.39 & 44.88 & 33.83 & 28.85 & 0.909311 & 22.46083 \\
\hline $5 / 3 / 2007$ & $16: 30$ & 29.65 & 30.29 & 0.38 & 0.334 & 45.99 & 36.92 & 28.98 & 1.010507 & 26.56414 \\
\hline $5 / 3 / 2007$ & $17: 00$ & 29.26 & 29.78 & 0.58 & 0.302 & 46.96 & 37.21 & 28.86 & 0.783596 & 17.94088 \\
\hline $5 / 3 / 2007$ & $17: 30$ & 29.26 & 29.81 & 0.5 & 0.057 & 47.17 & 36.69 & 28.86 & 0.827465 & 19.44327 \\
\hline $6 / 3 / 2007$ & $18: 00$ & 28.94 & 29.6 & 0.6 & 0.024 & 46.96 & 39.21 & 28.58 & 0.641523 & 13.64035 \\
\hline 6/3/2007 & $8: 00$ & 26.18 & 24.58 & 0.34 & 1.137 & 57.39 & 58.93 & 25.66 & -0.21426 & 5.952234 \\
\hline 6/3/2007 & $8: 30$ & 26.62 & 25.75 & 0.31 & 1.175 & 56.66 & 56.27 & 26.06 & -0.01468 & 5.00446 \\
\hline $6 / 3 / 2007$ & 9:00 & 26.92 & 26.47 & 0.39 & 1.495 & 56.94 & 55.26 & 26.37 & 0.015564 & 5.005015 \\
\hline 6/3/2007 & 9:30 & 27.19 & 26.98 & 0.38 & 1.35 & 56.99 & 54.58 & 26.67 & 0.139266 & 5.401831 \\
\hline 6/3/2007 & $10: 00$ & 27.69 & 27.42 & 0.5 & 1.692 & 55.57 & 53.22 & 27.15 & 0.226206 & 6.061591 \\
\hline 6/3/2007 & $10: 30$ & 27.92 & 28 & 0.55 & 1.605 & 54.19 & 51.32 & 27.48 & 0.289021 & 6.735359 \\
\hline 6/3/2007 & 11:00 & 28.74 & 28.08 & 0.52 & 1.851 & 53.4 & 51.21 & 27.93 & 0.634647 & 13.45434 \\
\hline 6/3/2007 & $11: 30$ & 29 & 28.96 & 0.48 & 1.447 & 51.51 & 48.48 & 28.49 & 0.756806 & 17.06361 \\
\hline 6/3/2007 & $12: 00$ & 29.67 & 29.37 & 0.47 & 1.441 & 50.35 & 46.69 & 29.18 & 1.034644 & 27.60091 \\
\hline $6 / 3 / 2007$ & $12: 30$ & 29.8 & 30.13 & 0.16 & 1.302 & 49.4 & 44.6 & 29.22 & 1.29676 & 40.10187 \\
\hline $6 / 3 / 2007$ & $13: 00$ & 29.97 & 30.34 & 0.21 & 1.248 & 49.7 & 42.73 & 29.13 & 1.271877 & 38.83083 \\
\hline 6/3/2007 & $13: 30$ & 29.95 & 30.39 & 0.18 & 0.855 & 49.91 & 42.97 & 29.2 & 1.308324 & 40.69736 \\
\hline $6 / 3 / 2007$ & $14: 00$ & 30.5 & 31.68 & 0.46 & 0.836 & 46.99 & 39.96 & 30.06 & 1.359418 & 43.36183 \\
\hline 6/3/2007 & $14: 30$ & 30.66 & 31.42 & 0.52 & 0.78 & 46.63 & 39.1 & 30.23 & 1.400701 & 45.54916 \\
\hline 6/3/2007 & $15: 00$ & 30.4 & 32.14 & 0.53 & 0.697 & 46.07 & 37.67 & 30.13 & 1.301498 & 40.34551 \\
\hline 6/3/2007 & $15: 30$ & 30.29 & 31.25 & 0.51 & 0.492 & 47.63 & 39.44 & 29.9 & 1.26309 & 38.38556 \\
\hline $6 / 3 / 2007$ & $16: 00$ & 29.91 & 30.7 & 0.52 & 1.279 & 53.3 & 44.96 & 29.73 & 1.18155 & 34.35076 \\
\hline $6 / 3 / 2007$ & $16: 30$ & 29.87 & 28.76 & 0.42 & 0.292 & 52.36 & 53.26 & 29.54 & 1.186451 & 34.58796 \\
\hline $6 / 3 / 2007$ & $17: 00$ & 29.87 & 29.9 & 0.54 & 0.106 & 50.38 & 47.34 & 29.56 & 1.109141 & 30.93319 \\
\hline 6/3/2007 & $17: 30$ & 29.74 & 30.25 & 0.56 & 0.146 & 49.62 & 46.86 & 29.39 & 1.031562 & 27.4673 \\
\hline $7 / 3 / 2007$ & $18: 00$ & 29.65 & 29.54 & 0.33 & 0.445 & 51.79 & 50.7 & 29.25 & 1.138326 & 32.29053 \\
\hline 7/3/2007 & 8:00 & 26.78 & 25.14 & 0.29 & 0.598 & 59.06 & 62.59 & 26.29 & 0.103441 & 5.221603 \\
\hline $7 / 3 / 2007$ & $8: 30$ & 26.84 & 26.33 & 0.39 & 0.765 & 58.82 & 58.17 & 26.36 & 0.008257 & 5.001411 \\
\hline $7 / 3 / 2007$ & 9:00 & 27.29 & 26.95 & 0.37 & 1.027 & 59.19 & 57.29 & 26.7 & 0.199103 & 5.822037 \\
\hline 7/3/2007 & 9:30 & 27.76 & 27.41 & 0.45 & 1.556 & 58.63 & 57.07 & 27.21 & 0.31974 & 7.125441 \\
\hline $7 / 3 / 2007$ & $10: 00$ & 28.21 & 28.04 & 0.56 & 1.573 & 58.23 & 56.27 & 27.76 & 0.441763 & 9.0713 \\
\hline
\end{tabular}




\begin{tabular}{|c|c|c|c|c|c|c|c|c|c|c|}
\hline $7 / 3 / 2007$ & $10: 30$ & 28.56 & 28.46 & 0.55 & 1.678 & 56.43 & 53.75 & 28.14 & 0.585792 & 12.19173 \\
\hline $7 / 3 / 2007$ & $11: 00$ & 28.85 & 29.05 & 0.58 & 1.511 & 53.98 & 50.92 & 28.46 & 0.674802 & 14.56961 \\
\hline 7/3/2007 & $11: 30$ & 29.31 & 29.63 & 0.45 & 1.27 & 53.31 & 49.94 & 28.82 & 0.924165 & 23.03783 \\
\hline 7/3/2007 & $12: 00$ & 29.75 & 29.76 & 0.56 & 1.315 & 51.4 & 49.45 & 29.32 & 1.04308 & 27.96831 \\
\hline $7 / 3 / 2007$ & $12: 30$ & 30.09 & 30.12 & 0.19 & 1.247 & 51.32 & 47.9 & 29.31 & 1.359562 & 43.36941 \\
\hline $7 / 3 / 2007$ & 13:00 & 30.29 & 30.67 & 0.22 & 1.438 & 51.41 & 45.62 & 29.47 & 1.403662 & 45.70708 \\
\hline $7 / 3 / 2007$ & $13: 30$ & 30.4 & 31.04 & 0.19 & 1.259 & 51.31 & 43.8 & 29.56 & 1.464802 & 48.99233 \\
\hline 7/3/2007 & $14: 00$ & 30.8 & 31.44 & 0.41 & 1.263 & 48.77 & 43.3 & 30.09 & 1.486743 & 50.18052 \\
\hline $7 / 3 / 2007$ & $14: 30$ & 30.97 & 31.42 & 0.57 & 1.154 & 47.11 & 42.8 & 30.56 & 1.524379 & 52.22591 \\
\hline 7/3/2007 & $15: 00$ & 31.23 & 32.31 & 0.4 & 1.099 & 46.8 & 39.82 & 30.71 & 1.672706 & 60.28553 \\
\hline $7 / 3 / 2007$ & $15: 30$ & 31.43 & 32.34 & 0.54 & 1.203 & 44.79 & 38.89 & 31.08 & 1.714065 & 62.50329 \\
\hline $7 / 3 / 2007$ & $16: 00$ & 31.35 & 32.24 & 0.48 & 1.25 & 45.32 & 38.12 & 30.98 & 1.700433 & 61.77487 \\
\hline 7/3/2007 & $16: 30$ & 31.17 & 32.3 & 0.43 & 0.958 & 42.79 & 34.75 & 30.76 & 1.609631 & 56.86923 \\
\hline $7 / 3 / 2007$ & $17: 00$ & 31.03 & 32.33 & 0.46 & 0.809 & 44.04 & 35.69 & 30.59 & 1.549762 & 53.60848 \\
\hline $7 / 3 / 2007$ & $17: 30$ & 30.88 & 32.1 & 0.52 & 0.635 & 44.61 & 37.06 & 30.4 & 1.466469 & 49.08247 \\
\hline 8/3/2007 & $18: 00$ & 30.59 & 31.55 & 0.27 & 0.471 & 45.58 & 38.83 & 30.07 & 1.467305 & 49.12767 \\
\hline 8/3/2007 & 8:00 & 26.66 & 25.06 & 0.28 & 0.562 & 63.82 & 67.92 & 26.29 & 0.126881 & 5.333492 \\
\hline 8/3/2007 & 8:30 & 27.07 & 26.12 & 0.32 & 0.82 & 62.35 & 63.12 & 26.57 & 0.205283 & 5.873957 \\
\hline 8/3/2007 & 9:00 & 27.58 & 27.21 & 0.45 & 1.102 & 60.43 & 58.18 & 27.04 & 0.261908 & 6.424177 \\
\hline 8/3/2007 & $9: 30$ & 27.83 & 27.47 & 0.43 & 1.402 & 58.61 & 56.95 & 27.4 & 0.381008 & 8.023021 \\
\hline 8/3/2007 & $10: 00$ & 28.32 & 27.64 & 0.4 & 1.533 & 58.79 & 57.84 & 27.87 & 0.606053 & 12.70277 \\
\hline 8/3/2007 & $10: 30$ & 28.73 & 28.55 & 0.55 & 1.563 & 55.81 & 54.11 & 28.34 & 0.656914 & 14.06414 \\
\hline 8/3/2007 & $11: 00$ & 29.26 & 29.03 & 0.46 & 1.579 & 55.2 & 52.18 & 28.84 & 0.924809 & 23.06304 \\
\hline 8/3/2007 & $11: 30$ & 29.64 & 29.55 & 0.51 & 1.495 & 50.7 & 49.09 & 29.24 & 1.016818 & 26.83314 \\
\hline 8/3/2007 & $12: 00$ & 30.25 & 29.73 & 0.54 & 1.64 & 50.21 & 48.49 & 29.76 & 1.246782 & 37.56425 \\
\hline 8/3/2007 & $12: 30$ & 30.52 & 29.81 & 0.15 & 1.534 & 49.57 & 47.74 & 29.75 & 1.537387 & 52.93429 \\
\hline 8/3/2007 & $13: 00$ & 30.51 & 30.46 & 0.18 & 1.611 & 49.93 & 45.65 & 29.71 & 1.505647 & 51.20696 \\
\hline 8/3/2007 & $13: 30$ & 30.7 & 31.09 & 0.17 & 1.22 & 49.89 & 43.87 & 30 & 1.598451 & 56.26098 \\
\hline 8/3/2007 & $14: 00$ & 30.64 & 31.59 & 0.46 & 1.444 & 46.53 & 40.12 & 30.26 & 1.421211 & 46.64542 \\
\hline 8/3/2007 & $14: 30$ & 31.21 & 31.66 & 0.5 & 1.367 & 45.59 & 40.39 & 30.82 & 1.63532 & 58.26434 \\
\hline 8/3/2007 & $15: 00$ & 31.43 & 32.39 & 0.52 & 1.165 & 43.82 & 37.63 & 31.08 & 1.70904 & 62.23509 \\
\hline 8/3/2007 & $15: 30$ & 31.42 & 32.51 & 0.55 & 0.851 & 42.67 & 34.66 & 31.09 & 1.686704 & 61.03862 \\
\hline 8/3/2007 & $16: 00$ & 31.37 & 32.59 & 0.53 & 0.963 & 40.63 & 33.16 & 30.98 & 1.640857 & 58.56448 \\
\hline 8/3/2007 & $16: 30$ & 31.21 & 31.8 & 0.56 & 1.297 & 41.5 & 34.21 & 30.79 & 1.569552 & 54.68696 \\
\hline 8/3/2007 & $17: 00$ & 31.11 & 32.09 & 0.51 & 0.912 & 41.63 & 33.74 & 30.71 & 1.546191 & 53.4139 \\
\hline 8/3/2007 & $17: 30$ & 30.82 & 32.08 & 0.55 & 0.572 & 40.86 & 33.27 & 30.47 & 1.408505 & 45.96561 \\
\hline $8 / 3 / 2007$ & $18: 00$ & 30.53 & 31.65 & 0.51 & 0.525 & 42.15 & 34.48 & 30.18 & 1.31366 & 40.97313 \\
\hline
\end{tabular}


Ambiente: Assistência Administrativa

Período 3: 11 a 14 de junho de 2007

\begin{tabular}{|c|c|c|c|c|c|c|c|c|c|c|}
\hline Data & Hora & Temp. int. & Temp. ext. & Vel. int. & Vel. ext. & UR int. & UR ext. & $\begin{array}{l}\text { Temp. } \\
\text { Globo int. }\end{array}$ & PMV & PPD \\
\hline $11 / 6 / 2007$ & 8:00 & 20.19 & 12.77 & 0.14 & 0 & 63.58 & 89.9 & 19.48 & -0.90876 & 22.43957 \\
\hline $11 / 6 / 2007$ & $8: 30$ & 20.77 & 15.77 & 0.13 & 0 & 65.15 & 79.7 & 19.92 & -0.73511 & 16.37568 \\
\hline $11 / 6 / 2007$ & 9:00 & 21.34 & 18.98 & 0.11 & 0.042 & 63.63 & 71 & 20.46 & -0.54244 & 11.15798 \\
\hline $11 / 6 / 2007$ & 9:30 & 21.9 & 22.47 & 0.17 & 0.343 & 62.82 & 57.47 & 20.95 & -0.54141 & 11.1346 \\
\hline $11 / 6 / 2007$ & $10: 00$ & 22.42 & 23.54 & 0.1 & 0.402 & 60.14 & 52.26 & 21.5 & -0.25803 & 6.382244 \\
\hline $11 / 6 / 2007$ & $10: 30$ & 22.91 & 23.76 & 0.12 & 0.777 & 57.57 & 50.29 & 22.04 & -0.18947 & 5.744337 \\
\hline $11 / 6 / 2007$ & $11: 00$ & 23.46 & 23.83 & 0.14 & 1.004 & 56.68 & 50.4 & 22.57 & -0.09123 & 5.172364 \\
\hline $11 / 6 / 2007$ & $11: 30$ & 23.92 & 24.14 & 0.12 & 0.929 & 55.92 & 49.78 & 23.01 & 0.064066 & 5.084981 \\
\hline $11 / 6 / 2007$ & $12: 00$ & 24.36 & 24.85 & 0.14 & 0.943 & 54.25 & 47.44 & 23.43 & 0.131479 & 5.35812 \\
\hline $11 / 6 / 2007$ & $12: 30$ & 23.91 & 25.3 & 0.12 & 0.901 & 55.86 & 45.68 & 23.17 & 0.081084 & 5.136139 \\
\hline $11 / 6 / 2007$ & $13: 00$ & 23.76 & 25.78 & 0.13 & 1.294 & 56.53 & 43.48 & 22.99 & 0.021736 & 5.009781 \\
\hline $11 / 6 / 2007$ & $13: 30$ & 23.9 & 26.04 & 0.1 & 1.315 & 56.42 & 42.37 & 23 & 0.107229 & 5.238139 \\
\hline $11 / 6 / 2007$ & $14: 00$ & 24.36 & 26.39 & 0.16 & 1.55 & 54.23 & 40.72 & 23.28 & 0.081973 & 5.139142 \\
\hline $11 / 6 / 2007$ & $14: 30$ & 25.39 & 26.65 & 0.15 & 1.144 & 50.57 & 40.02 & 24.49 & 0.373294 & 7.901206 \\
\hline $11 / 6 / 2007$ & $15: 00$ & 25.56 & 26.73 & 0.12 & 1.297 & 49.86 & 39.28 & 24.74 & 0.469455 & 9.601674 \\
\hline $11 / 6 / 2007$ & $15: 30$ & 25.95 & 26.97 & 0.16 & 0.894 & 47.89 & 38.14 & 25.04 & 0.49199 & 10.05767 \\
\hline $11 / 6 / 2007$ & $16: 00$ & 25.94 & 26.99 & 0.14 & 0.824 & 48.32 & 37.78 & 25.13 & 0.530823 & 10.89491 \\
\hline $11 / 6 / 2007$ & $16: 30$ & 25.77 & 26.87 & 0.13 & 0.767 & 47.3 & 36.73 & 24.91 & 0.485131 & 9.91655 \\
\hline $11 / 6 / 2007$ & $17: 00$ & 25.44 & 26.21 & 0.13 & 0.533 & 48.61 & 39.52 & 24.51 & 0.39804 & 8.300946 \\
\hline $11 / 6 / 2007$ & $17: 30$ & 25.15 & 26.22 & 0.11 & 0.186 & 50.15 & 40.47 & 24.25 & 0.370528 & 7.858154 \\
\hline $11 / 6 / 2007$ & $18: 00$ & 24.49 & 23.97 & 0.11 & 0 & 52.32 & 48.19 & 23.73 & 0.228554 & 6.083791 \\
\hline $12 / 6 / 2007$ & 8:00 & 20.89 & 12.84 & 0.16 & 0 & 61.18 & 87.5 & 20.19 & -0.78006 & 17.82338 \\
\hline $12 / 6 / 2007$ & $8: 30$ & 21.3 & 16.04 & 0.21 & 0.048 & 61.22 & 76.5 & 20.59 & -0.76399 & 17.29589 \\
\hline $12 / 6 / 2007$ & 9:00 & 21.68 & 20.22 & 0.19 & 0.19 & 60.76 & 63.72 & 21.02 & -0.62037 & 13.07466 \\
\hline $12 / 6 / 2007$ & $9: 30$ & 21.95 & 21.34 & 0.36 & 1.077 & 59.56 & 58.89 & 21.42 & -0.76086 & 17.19455 \\
\hline $12 / 6 / 2007$ & $10: 00$ & 22.48 & 21.87 & 0.37 & 1.28 & 57.94 & 56.22 & 21.88 & -0.62891 & 13.30061 \\
\hline $12 / 6 / 2007$ & $10: 30$ & 23.25 & 22.9 & 0.2 & 1.136 & 55.58 & 52.42 & 22.46 & -0.24506 & 6.246414 \\
\hline $12 / 6 / 2007$ & 11:00 & 23.88 & 23.3 & 0.17 & 1.521 & 51.53 & 48.27 & 22.98 & -0.06435 & 5.085748 \\
\hline $12 / 6 / 2007$ & $11: 30$ & 24.46 & 23.97 & 0.12 & 1.646 & 48.83 & 44.99 & 23.56 & 0.158638 & 5.521527 \\
\hline $12 / 6 / 2007$ & $12: 00$ & 24.96 & 24.68 & 0.19 & 1.644 & 47.29 & 42.58 & 24.04 & 0.173854 & 5.626512 \\
\hline $12 / 6 / 2007$ & $12: 30$ & 24.6 & 25.25 & 0.17 & 1.735 & 47.81 & 38.95 & 23.95 & 0.135493 & 5.380335 \\
\hline $12 / 6 / 2007$ & $13: 00$ & 24.43 & 25.84 & 0.13 & 1.41 & 49.5 & 37.93 & 23.58 & 0.142688 & 5.421839 \\
\hline $12 / 6 / 2007$ & $13: 30$ & 24.46 & 26.43 & 0.14 & 1.619 & 49.98 & 35.68 & 23.59 & 0.13472 & 5.376008 \\
\hline $12 / 6 / 2007$ & $14: 00$ & 24.59 & 26.62 & 0.17 & 1.573 & 49.95 & 35 & 23.65 & 0.115588 & 5.276733 \\
\hline $12 / 6 / 2007$ & $14: 30$ & 25.94 & 26.98 & 0.13 & 1.26 & 44.54 & 35.07 & 25.04 & 0.504404 & 10.31823 \\
\hline $12 / 6 / 2007$ & $15: 00$ & 26.25 & 27.18 & 0.12 & 1.319 & 42.15 & 32.29 & 25.38 & 0.586886 & 12.21888 \\
\hline $12 / 6 / 2007$ & $15: 30$ & 26.57 & 27.25 & 0.17 & 1.323 & 40.91 & 31.7 & 25.63 & 0.591608 & 12.33661 \\
\hline $12 / 6 / 2007$ & $16: 00$ & 26.53 & 27.41 & 0.14 & 1.155 & 39.79 & 30.08 & 25.5 & 0.596087 & 12.44918 \\
\hline $12 / 6 / 2007$ & $16: 30$ & 26.19 & 27.5 & 0.1 & 0.686 & 41.6 & 30.56 & 25.26 & 0.592029 & 12.34714 \\
\hline $12 / 6 / 2007$ & $17: 00$ & 25.97 & 27.32 & 0.13 & 0.322 & 42.05 & 32.14 & 25.02 & 0.486792 & 9.950529 \\
\hline $12 / 6 / 2007$ & $17: 30$ & 25.63 & 26.58 & 0.11 & 0.149 & 44.49 & 34.29 & 24.72 & 0.452871 & 9.280072 \\
\hline $12 / 6 / 2007$ & $18: 00$ & 24.94 & 24.21 & 0.09 & 0 & 47.04 & 42.13 & 24.19 & 0.352301 & 7.582575 \\
\hline $13 / 6 / 2007$ & 8:00 & 20.89 & 17.46 & 0.25 & 0.828 & 56.94 & 64.31 & 20.37 & -0.94893 & 24.01938 \\
\hline $13 / 6 / 2007$ & $8: 30$ & 21.4 & 18.77 & 0.18 & 1.104 & 55.79 & 59.54 & 20.72 & -0.71124 & 15.642 \\
\hline $13 / 6 / 2007$ & 9:00 & 21.99 & 20.22 & 0.16 & 0.665 & 54.59 & 55.57 & 21.25 & -0.52545 & 10.77517 \\
\hline $13 / 6 / 2007$ & $9: 30$ & 22.54 & 21.54 & 0.15 & 0.769 & 53.26 & 51.24 & 21.76 & -0.36968 & 7.844993 \\
\hline $13 / 6 / 2007$ & $10: 00$ & 23.01 & 22.64 & 0.26 & 0.846 & 52.25 & 48.71 & 22.25 & -0.41099 & 8.520628 \\
\hline
\end{tabular}




\begin{tabular}{|c|c|c|c|c|c|c|c|c|c|c|}
\hline $13 / 6 / 2007$ & $10: 30$ & 23.57 & 22.82 & 0.1 & 1.527 & 51.15 & 47.95 & 22.71 & -0.01074 & 5.00239 \\
\hline $13 / 6 / 2007$ & $11: 00$ & 23.97 & 23.38 & 0.16 & 1.129 & 50.82 & 47.43 & 23.13 & -0.02212 & 5.010129 \\
\hline $13 / 6 / 2007$ & $11: 30$ & 24.7 & 24.22 & 0.19 & 1.524 & 48.31 & 43.47 & 23.74 & 0.10449 & 5.226123 \\
\hline $13 / 6 / 2007$ & $12: 00$ & 25.17 & 24.65 & 0.17 & 1.985 & 45.21 & 40.13 & 24.22 & 0.239032 & 6.185691 \\
\hline $13 / 6 / 2007$ & $12: 30$ & 24.79 & 25.23 & 0.12 & 1.45 & 47.01 & 38.08 & 23.95 & 0.240074 & 6.196075 \\
\hline $13 / 6 / 2007$ & 13:00 & 24.68 & 25.75 & 0.11 & 1.773 & 47.5 & 35.67 & 23.79 & 0.227887 & 6.077463 \\
\hline $13 / 6 / 2007$ & $13: 30$ & 24.78 & 25.96 & 0.1 & 1.855 & 47.09 & 32.65 & 23.84 & 0.26556 & 6.464281 \\
\hline $13 / 6 / 2007$ & $14: 00$ & 24.98 & 26.28 & 0.13 & 1.765 & 46.16 & 33.22 & 23.97 & 0.246553 & 6.261668 \\
\hline $13 / 6 / 2007$ & $14: 30$ & 26.16 & 26.7 & 0.14 & 1.35 & 42.41 & 33.64 & 25.29 & 0.536398 & 11.02046 \\
\hline $13 / 6 / 2007$ & $15: 00$ & 26.42 & 27.03 & 0.14 & 1.498 & 42.07 & 32.74 & 25.54 & 0.602726 & 12.61764 \\
\hline $13 / 6 / 2007$ & $15: 30$ & 26.53 & 26.84 & 0.15 & 1.484 & 42.27 & 33.38 & 25.67 & 0.623973 & 13.16963 \\
\hline $13 / 6 / 2007$ & $16: 00$ & 26.46 & 26.87 & 0.2 & 1.232 & 43.24 & 34.47 & 25.63 & 0.561152 & 11.59422 \\
\hline $13 / 6 / 2007$ & $16: 30$ & 26.31 & 26.96 & 0.14 & 1.076 & 43.42 & 34.35 & 25.43 & 0.583908 & 12.1451 \\
\hline $13 / 6 / 2007$ & $17: 00$ & 26.09 & 26.59 & 0.15 & 0.835 & 44.56 & 35.63 & 25.21 & 0.520148 & 10.65827 \\
\hline $13 / 6 / 2007$ & $17: 30$ & 25.75 & 26.2 & 0.13 & 0.187 & 46.17 & 38.87 & 24.86 & 0.467341 & 9.560012 \\
\hline $13 / 6 / 2007$ & $18: 00$ & 25.09 & 24.2 & 0.09 & 0 & 48.39 & 45.94 & 24.36 & 0.403709 & 8.396202 \\
\hline $14 / 6 / 2007$ & $8: 00$ & 21.57 & 13 & 0.12 & 0.108 & 58.08 & 84.7 & 20.89 & -0.51917 & 10.63681 \\
\hline $14 / 6 / 2007$ & $8: 30$ & 22.04 & 15.18 & 0.14 & 0.066 & 57.52 & 77.3 & 21.3 & -0.45193 & 9.26225 \\
\hline $14 / 6 / 2007$ & 9:00 & 22.55 & 18.76 & 0.15 & 0.024 & 56.9 & 67.23 & 21.77 & -0.34347 & 7.454138 \\
\hline $14 / 6 / 2007$ & $9: 30$ & 23.16 & 22.03 & 0.15 & 0.202 & 55.83 & 59.53 & 22.31 & -0.19262 & 5.769291 \\
\hline $14 / 6 / 2007$ & $10: 00$ & 23.61 & 24.44 & 0.14 & 0.233 & 56.23 & 52.31 & 22.76 & -0.04902 & 5.049751 \\
\hline $14 / 6 / 2007$ & $10: 30$ & 24.18 & 25.16 & 0.18 & 0.489 & 55.99 & 48.97 & 23.29 & 0.036704 & 5.027889 \\
\hline $14 / 6 / 2007$ & $11: 00$ & 24.68 & 25.27 & 0.14 & 0.777 & 54.05 & 47.17 & 23.75 & 0.217118 & 5.97784 \\
\hline $14 / 6 / 2007$ & $11: 30$ & 25.18 & 25.48 & 0.16 & 0.823 & 52.55 & 47.54 & 24.2 & 0.307303 & 6.962703 \\
\hline $14 / 6 / 2007$ & $12: 00$ & 25.54 & 26 & 0.11 & 0.938 & 50.75 & 44.09 & 24.61 & 0.475081 & 9.713462 \\
\hline $14 / 6 / 2007$ & $12: 30$ & 25.22 & 26.37 & 0.11 & 1.072 & 51.25 & 41.99 & 24.48 & 0.416799 & 8.621417 \\
\hline $14 / 6 / 2007$ & $13: 00$ & 25.22 & 26.81 & 0.11 & 1.127 & 51.45 & 40.19 & 24.34 & 0.401364 & 8.356628 \\
\hline $14 / 6 / 2007$ & $13: 30$ & 25.32 & 27.36 & 0.12 & 0.998 & 51.33 & 39.05 & 24.39 & 0.403179 & 8.387243 \\
\hline $14 / 6 / 2007$ & $14: 00$ & 25.89 & 27.52 & 0.17 & 0.986 & 49.78 & 38.63 & 24.75 & 0.451836 & 9.260405 \\
\hline $14 / 6 / 2007$ & $14: 30$ & 26.38 & 27.9 & 0.12 & 1.252 & 47.47 & 37.24 & 25.57 & 0.671888 & 14.48631 \\
\hline $14 / 6 / 2007$ & $15: 00$ & 26.74 & 27.85 & 0.14 & 1.265 & 46.75 & 37.38 & 25.8 & 0.721014 & 15.93945 \\
\hline $14 / 6 / 2007$ & $15: 30$ & 26.78 & 27.93 & 0.11 & 0.9 & 46.37 & 37 & 25.98 & 0.786264 & 18.02993 \\
\hline $14 / 6 / 2007$ & $16: 00$ & 26.77 & 28.06 & 0.17 & 0.919 & 46.22 & 35.44 & 25.97 & 0.706923 & 15.51197 \\
\hline $14 / 6 / 2007$ & $16: 30$ & 26.79 & 28 & 0.12 & 0.685 & 46.36 & 36.19 & 25.84 & 0.75605 & 17.03929 \\
\hline $14 / 6 / 2007$ & $17: 00$ & 26.65 & 27.49 & 0.1 & 0.549 & 46.63 & 37.6 & 25.75 & 0.757342 & 17.08087 \\
\hline $14 / 6 / 2007$ & $17: 30$ & 26.37 & 26.5 & 0.11 & 0.524 & 47.77 & 40.86 & 25.44 & 0.672538 & 14.50488 \\
\hline $14 / 6 / 2007$ & $18: 00$ & 25.75 & 24.7 & 0.12 & 0.072 & 49.47 & 46.87 & 24.93 & 0.517404 & 10.59822 \\
\hline
\end{tabular}


Ambiente: Assistência Administrativa

Período 4: 26 a 29 de junho de 2007

\begin{tabular}{|c|c|c|c|c|c|c|c|c|c|c|}
\hline Data & Hora & Temp. int. & Temp. ext. & Vel. int. & Vel. ext. & UR int. & UR ext. & $\begin{array}{l}\text { Temp. } \\
\text { Globo int. }\end{array}$ & PMV & PPD \\
\hline 26/6/2007 & 9:00 & 21.92 & 19.34 & 0.16 & 0.185 & 58.41 & 70.8 & 21.33 & -0.50395 & 10.30867 \\
\hline $26 / 6 / 2007$ & 9:30 & 22.25 & 19.18 & 0.16 & 0.238 & 57.76 & 71.3 & 21.64 & -0.42015 & 8.680206 \\
\hline $26 / 6 / 2007$ & $10: 00$ & 22.58 & 19.09 & 0.24 & 0.133 & 56.95 & 71.8 & 21.94 & -0.46551 & 9.524085 \\
\hline $26 / 6 / 2007$ & $10: 30$ & 23.03 & 18.97 & 0.13 & 0.131 & 55.58 & 72.2 & 22.29 & -0.17746 & 5.652837 \\
\hline $26 / 6 / 2007$ & $11: 00$ & 23.79 & 18.82 & 0.19 & 0.222 & 54.22 & 72.7 & 22.93 & -0.09624 & 5.191808 \\
\hline $26 / 6 / 2007$ & $11: 30$ & 24.11 & 18.73 & 0.16 & 0.141 & 53.34 & 73.1 & 23.37 & 0.045433 & 5.042732 \\
\hline $26 / 6 / 2007$ & $12: 00$ & 24.42 & 18.62 & 0.13 & 0.215 & 52.49 & 73.4 & 23.65 & 0.171015 & 5.606191 \\
\hline 26/6/2007 & $12: 30$ & 24.42 & 18.5 & 0.19 & 0.136 & 52.27 & 73.8 & 23.69 & 0.080631 & 5.134622 \\
\hline $26 / 6 / 2007$ & $13: 00$ & 24.46 & 18.41 & 0.14 & 0.105 & 51.93 & 74.3 & 23.64 & 0.154656 & 5.495647 \\
\hline $26 / 6 / 2007$ & $13: 30$ & 24.56 & 18.27 & 0.11 & 0.068 & 51.4 & 74.8 & 23.7 & 0.22836 & 6.081946 \\
\hline 26/6/2007 & $14: 00$ & 25.16 & 18.18 & 0.1 & 0.118 & 48.74 & 75.2 & 24.1 & 0.362481 & 7.734753 \\
\hline $26 / 6 / 2007$ & $14: 30$ & 25.36 & 18.08 & 0.12 & 0.113 & 47.49 & 75.6 & 24.58 & 0.402534 & 8.376347 \\
\hline $26 / 6 / 2007$ & $15: 00$ & 25.69 & 18.01 & 0.2 & 0.166 & 46.47 & 75.9 & 24.87 & 0.371443 & 7.872365 \\
\hline 26/6/2007 & $15: 30$ & 25.82 & 17.94 & 0.21 & 0.155 & 47.14 & 76.2 & 24.99 & 0.401611 & 8.360786 \\
\hline $26 / 6 / 2007$ & $16: 00$ & 25.77 & 17.86 & 0.17 & 0.076 & 46.68 & 76.5 & 25.14 & 0.452363 & 9.270419 \\
\hline $26 / 6 / 2007$ & $16: 30$ & 25.65 & 17.78 & 0.25 & 0.127 & 46.76 & 76.8 & 24.96 & 0.326839 & 7.221274 \\
\hline 26/6/2007 & $17: 00$ & 25.48 & 17.72 & 0.27 & 0.155 & 47.46 & 77.1 & 24.76 & 0.262057 & 6.425799 \\
\hline $26 / 6 / 2007$ & $17: 30$ & 25 & 17.65 & 0.33 & 0.118 & 48.88 & 77.4 & 24.43 & 0.097254 & 5.195874 \\
\hline $26 / 6 / 2007$ & $18: 00$ & 24.56 & 17.56 & 0.11 & 0.23 & 51.16 & 77.8 & 23.95 & 0.256732 & 6.368286 \\
\hline $27 / 6 / 2007$ & 8:00 & 21.96 & 16.14 & 0.11 & 0.091 & 56.86 & 83.7 & 21.12 & -0.41654 & 8.616807 \\
\hline 27/6/2007 & $8: 30$ & 22.24 & 16.12 & 0.15 & 0.067 & 56.8 & 83.7 & 21.51 & -0.42253 & 8.722339 \\
\hline $27 / 6 / 2007$ & 9:00 & 22.73 & 16.07 & 0.16 & 0.046 & 56.35 & 83.9 & 22.01 & -0.31032 & 7.001531 \\
\hline $27 / 6 / 2007$ & 9:30 & 23.15 & 16.03 & 0.19 & 0.047 & 56.56 & 84.1 & 22.43 & -0.24379 & 6.23345 \\
\hline 27/6/2007 & $10: 00$ & 23.39 & 15.97 & 0.25 & 0.07 & 55.3 & 84.3 & 22.8 & -0.25156 & 6.313602 \\
\hline $27 / 6 / 2007$ & $10: 30$ & 23.85 & 15.93 & 0.25 & 0.092 & 53.53 & 84.5 & 23.2 & -0.13762 & 5.39237 \\
\hline $27 / 6 / 2007$ & $11: 00$ & 24.06 & 15.91 & 0.14 & 0.024 & 53.43 & 84.5 & 23.29 & 0.062736 & 5.081486 \\
\hline 27/6/2007 & $11: 30$ & 24.4 & 15.88 & 0.23 & 0 & 54.11 & 84.5 & 23.6 & 0.030788 & 5.019622 \\
\hline 27/6/2007 & $12: 00$ & 24.78 & 15.81 & 0.24 & 0.024 & 52.22 & 84.7 & 23.98 & 0.115695 & 5.27725 \\
\hline $27 / 6 / 2007$ & $12: 30$ & 24.76 & 15.77 & 0.13 & 0.014 & 52.72 & 84.9 & 23.96 & 0.260867 & 6.41284 \\
\hline 27/6/2007 & $13: 00$ & 24.74 & 15.71 & 0.15 & 0.035 & 52.86 & 85.1 & 23.92 & 0.221522 & 6.017991 \\
\hline 27/6/2007 & $13: 30$ & 24.85 & 15.68 & 0.12 & 0.029 & 52.85 & 85.2 & 23.97 & 0.294527 & 6.802346 \\
\hline $27 / 6 / 2007$ & $14: 00$ & 25.14 & 15.69 & 0.15 & 0.042 & 52.49 & 85.1 & 24.12 & 0.3054 & 6.938374 \\
\hline $27 / 6 / 2007$ & $14: 30$ & 26.03 & 15.69 & 0.15 & 0.04 & 51 & 84.9 & 25.11 & 0.550313 & 11.33973 \\
\hline $27 / 6 / 2007$ & $15: 00$ & 26.51 & 15.68 & 0.17 & 0.024 & 49.77 & 84.9 & 25.59 & 0.649824 & 13.86765 \\
\hline $27 / 6 / 2007$ & $15: 30$ & 26.63 & 15.63 & 0.21 & 0.013 & 47.86 & 84.9 & 25.78 & 0.635398 & 13.47456 \\
\hline $27 / 6 / 2007$ & $16: 00$ & 26.53 & 15.61 & 0.29 & 0.04 & 48.84 & 85 & 25.75 & 0.557887 & 11.51703 \\
\hline 27/6/2007 & $16: 30$ & 25.92 & 15.61 & 0.37 & 0.032 & 49.44 & 85 & 25.3 & 0.34407 & 7.462765 \\
\hline $27 / 6 / 2007$ & $17: 00$ & 25.93 & 15.57 & 0.15 & 0.039 & 49.8 & 85.3 & 25.04 & 0.516762 & 10.58422 \\
\hline $27 / 6 / 2007$ & $17: 30$ & 25.7 & 15.51 & 0.17 & 0.023 & 50.19 & 85.4 & 24.81 & 0.43067 & 8.868095 \\
\hline $27 / 6 / 2007$ & $18: 00$ & 25.21 & 15.51 & 0.14 & 0 & 51.83 & 85.3 & 24.38 & 0.356677 & 7.647453 \\
\hline 28/6/2007 & 8:00 & 22.03 & 14.53 & 0.1 & 0 & 60.33 & 87.3 & 21.25 & -0.34186 & 7.431123 \\
\hline $28 / 6 / 2007$ & 8:30 & 22.4 & 14.45 & 0.12 & 0 & 58.55 & 87.4 & 21.69 & -0.29998 & 6.86996 \\
\hline 28/6/2007 & 9:00 & 22.83 & 14.41 & 0.15 & 0 & 57.84 & 87.8 & 22.12 & -0.25325 & 6.33129 \\
\hline 28/6/2007 & 9:30 & 23.25 & 14.4 & 0.15 & 0 & 55.78 & 87.9 & 22.57 & -0.14908 & 5.460521 \\
\hline 28/6/2007 & $10: 00$ & 23.43 & 14.42 & 0.28 & 0 & 54.83 & 88 & 22.85 & -0.27623 & 6.584741 \\
\hline $28 / 6 / 2007$ & $10: 30$ & 23.93 & 14.39 & 0.21 & 0 & 54.37 & 88.1 & 23.19 & -0.07012 & 5.10179 \\
\hline 28/6/2007 & $11: 00$ & 24.11 & 14.35 & 0.4 & 0.002 & 53.35 & 88.3 & 23.54 & -0.19123 & 5.758199 \\
\hline $28 / 6 / 2007$ & $11: 30$ & 24.68 & 14.36 & 0.27 & 0 & 52.05 & 88.4 & 23.95 & 0.062805 & 5.081666 \\
\hline
\end{tabular}




\begin{tabular}{|c|c|c|c|c|c|c|c|c|c|c|}
\hline 28/6/2007 & $12: 00$ & 25.11 & 14.35 & 0.25 & 0.02 & 50.89 & 88.2 & 24.31 & 0.190846 & 5.755169 \\
\hline 28/6/2007 & $12: 30$ & 25.31 & 14.37 & 0.2 & 0 & 51.64 & 88.1 & 24.47 & 0.301842 & 6.893315 \\
\hline $28 / 6 / 2007$ & $13: 00$ & 25.1 & 14.36 & 0.13 & 0.002 & 53.94 & 87.9 & 24.32 & 0.364358 & 7.763293 \\
\hline 28/6/2007 & $13: 30$ & 25.12 & 14.37 & 0.12 & 0.022 & 53.06 & 88 & 24.33 & 0.379321 & 7.996166 \\
\hline $28 / 6 / 2007$ & $14: 00$ & 25.28 & 14.41 & 0.11 & 0.03 & 52.4 & 87.8 & 24.43 & 0.428177 & 8.823151 \\
\hline 28/6/2007 & $14: 30$ & 26.05 & 14.47 & 0.2 & 0.001 & 49.12 & 87.2 & 25.23 & 0.493927 & 10.09789 \\
\hline $28 / 6 / 2007$ & $15: 00$ & 26.43 & 14.5 & 0.16 & 0.01 & 48.92 & 86.8 & 25.56 & 0.637669 & 13.53582 \\
\hline 28/6/2007 & $15: 30$ & 26.34 & 14.52 & 0.13 & 0.003 & 48.46 & 86.5 & 25.57 & 0.659246 & 14.12926 \\
\hline 28/6/2007 & $16: 00$ & 26.41 & 14.5 & 0.15 & 0.012 & 47.51 & 86.6 & 25.58 & 0.63738 & 13.52801 \\
\hline 28/6/2007 & $16: 30$ & 26.28 & 14.44 & 0.18 & 0.004 & 48.37 & 86.7 & 25.41 & 0.568921 & 11.77976 \\
\hline $28 / 6 / 2007$ & $17: 00$ & 26.11 & 14.36 & 0.21 & 0.006 & 49.16 & 87 & 25.23 & 0.49445 & 10.10876 \\
\hline 28/6/2007 & $17: 30$ & 25.86 & 14.32 & 0.19 & 0.001 & 48.91 & 87.1 & 25 & 0.444959 & 9.130817 \\
\hline 28/6/2007 & $18: 00$ & 25.31 & 14.32 & 0.21 & 0.043 & 50.1 & 87.1 & 24.57 & 0.289804 & 6.744808 \\
\hline 29/6/2007 & 8:00 & 21.83 & 15.12 & 0.13 & 0.014 & 58.34 & 79.3 & 21.1 & -0.47935 & 9.799248 \\
\hline 29/6/2007 & $8: 30$ & 21.94 & 15.06 & 0.13 & 0.025 & 60.41 & 79.5 & 21.25 & -0.43252 & 8.901612 \\
\hline 29/6/2007 & 9:00 & 22.49 & 15.11 & 0.14 & 0.033 & 60.4 & 79.2 & 21.79 & -0.30765 & 6.967187 \\
\hline 29/6/2007 & $9: 30$ & 23.01 & 15.18 & 0.13 & 0.029 & 60.47 & 78.9 & 22.22 & -0.15616 & 5.505346 \\
\hline 29/6/2007 & $10: 00$ & 23.17 & 15.18 & 0.21 & 0.028 & 61.36 & 78.8 & 22.56 & -0.22379 & 6.038991 \\
\hline 29/6/2007 & $10: 30$ & 23.58 & 15.12 & 0.22 & 0.035 & 58.5 & 79 & 23.01 & -0.13578 & 5.381976 \\
\hline 29/6/2007 & $11: 00$ & 23.45 & 15.22 & 0.31 & 0.062 & 59 & 78.3 & 23.11 & -0.24961 & 6.293272 \\
\hline 29/6/2007 & $11: 30$ & 23.55 & 15.33 & 0.27 & 0.05 & 58.98 & 77.8 & 23.1 & -0.18848 & 5.736518 \\
\hline 29/6/2007 & $12: 00$ & 23.91 & 15.38 & 0.18 & 0.023 & 57.58 & 77.7 & 23.28 & 0.001407 & 5.000041 \\
\hline 29/6/2007 & $12: 30$ & 24.28 & 15.37 & 0.11 & 0.038 & 55.02 & 77.7 & 23.48 & 0.187506 & 5.728928 \\
\hline 29/6/2007 & $13: 00$ & 24.51 & 15.35 & 0.1 & 0.015 & 53.94 & 77.7 & 23.68 & 0.258445 & 6.386658 \\
\hline 29/6/2007 & $13: 30$ & 24.72 & 15.34 & 0.1 & 0.042 & 53.16 & 77.8 & 23.84 & 0.301901 & 6.894056 \\
\hline 29/6/2007 & $14: 00$ & 24.78 & 15.37 & 0.17 & 0.035 & 52.23 & 77.4 & 24.01 & 0.204123 & 5.864086 \\
\hline 29/6/2007 & $14: 30$ & 25.04 & 15.37 & 0.14 & 0.014 & 48.97 & 77.4 & 24.27 & 0.29593 & 6.819609 \\
\hline 29/6/2007 & $15: 00$ & 25.27 & 15.33 & 0.15 & 0.031 & 49.52 & 77.5 & 24.5 & 0.347475 & 7.511987 \\
\hline 29/6/2007 & $15: 30$ & 25.5 & 15.24 & 0.16 & 0.012 & 49.61 & 77.8 & 24.65 & 0.388161 & 8.138222 \\
\hline 29/6/2007 & $16: 00$ & 25.56 & 15.18 & 0.15 & 0.001 & 48.28 & 78.2 & 24.78 & 0.416176 & 8.610527 \\
\hline 29/6/2007 & $16: 30$ & 25.46 & 15.16 & 0.13 & 0.018 & 48.8 & 78.4 & 24.69 & 0.423854 & 8.745843 \\
\hline 29/6/2007 & $17: 00$ & 25.38 & 15.17 & 0.16 & 0.012 & 49.76 & 78.1 & 24.55 & 0.358508 & 7.674839 \\
\hline 29/6/2007 & $17: 30$ & 25.1 & 15.13 & 0.13 & 0.011 & 52.48 & 78.3 & 24.35 & 0.356921 & 7.651092 \\
\hline $29 / 6 / 2007$ & $18: 00$ & 24.85 & 15.11 & 0.1 & 0.006 & 54.24 & 78.4 & 24.09 & 0.358797 & 7.679178 \\
\hline
\end{tabular}


Ambiente: Ante-sala da Congregação

Período 1: 21 a 24 de novembro de 2006

\begin{tabular}{|c|c|c|c|c|c|c|c|c|c|c|}
\hline Data & Hora & Temp. int. & Temp. ext. & Vel. int. & Vel. ext. & UR int. & UR ext. & $\begin{array}{c}\text { Temp. } \\
\text { Globo } \\
\text { int. }\end{array}$ & PMV & PPD \\
\hline $21 / 11 / 2006$ & 8:00 & 23.29 & 19.39 & 0.14 & 0.16 & 71.82 & 86.9 & 22.76 & -0.75945 & 17.1487 \\
\hline $21 / 11 / 2006$ & $8: 30$ & 23.46 & 20.12 & 0.14 & 0.306 & 71.2 & 83.6 & 22.82 & -0.72116 & 15.94401 \\
\hline 21/11/2006 & $9: 00$ & 23.53 & 21.05 & 0.17 & 0.492 & 71.15 & 79.9 & 22.94 & -0.78524 & 17.99578 \\
\hline $21 / 11 / 2006$ & $9: 30$ & 23.83 & 21.96 & 0.23 & 0.408 & 70.49 & 76.3 & 23.27 & -0.83271 & 19.62826 \\
\hline $21 / 11 / 2006$ & $10: 00$ & 23.84 & 22.88 & 0.33 & 0.422 & 71.6 & 73 & 23.62 & -0.9746 & 25.06253 \\
\hline $21 / 11 / 2006$ & $10: 30$ & 23.34 & 23.76 & 0.42 & 0.373 & 74.5 & 68.74 & 23.14 & -1.29891 & 40.21221 \\
\hline 21/11/2006 & $11: 00$ & 23.9 & 24.38 & 0.38 & 0.463 & 72.02 & 66.61 & 23.6 & -1.04075 & 27.86642 \\
\hline $21 / 11 / 2006$ & $11: 30$ & 24.33 & 24.57 & 0.35 & 0.653 & 70.3 & 65.43 & 23.93 & -0.8471 & 20.14176 \\
\hline $21 / 11 / 2006$ & $12: 00$ & 24.67 & 25.2 & 0.55 & 0.268 & 67.48 & 63.12 & 24.53 & -0.95117 & 24.10924 \\
\hline 21/11/2006 & $12: 30$ & 25.25 & 25.87 & 0.33 & 0.587 & 65.71 & 61.92 & 24.76 & -0.49845 & 10.19232 \\
\hline $21 / 11 / 2006$ & $13: 00$ & 25.73 & 26.56 & 0.3 & 0.549 & 64.8 & 60.07 & 25.16 & -0.28348 & 6.669289 \\
\hline $21 / 11 / 2006$ & $13: 30$ & 26.01 & 26.93 & 0.77 & 0.592 & 64.57 & 59.58 & 25.65 & -0.59714 & 12.47583 \\
\hline $21 / 11 / 2006$ & $14: 00$ & 26.11 & 28.23 & 0.48 & 0.943 & 64.27 & 55.95 & 25.8 & -0.31735 & 7.093603 \\
\hline 21/11/2006 & $14: 30$ & 26.51 & 28.3 & 0.34 & 1.016 & 63.58 & 54.27 & 25.99 & -0.03337 & 5.023046 \\
\hline $21 / 11 / 2006$ & $15: 00$ & 26.44 & 28.23 & 0.8 & 1.097 & 62.79 & 54.47 & 26.24 & -0.41832 & 8.647981 \\
\hline 21/11/2006 & $15: 30$ & 27.19 & 28.31 & 0.45 & 1.145 & 59.86 & 54.95 & 26.71 & 0.102737 & 5.218593 \\
\hline $21 / 11 / 2006$ & $16: 00$ & 27.12 & 28.33 & 0.76 & 0.953 & 60.65 & 54.36 & 26.75 & -0.12552 & 5.326357 \\
\hline $21 / 11 / 2006$ & $16: 30$ & 27.02 & 28.26 & 0.46 & 0.981 & 60.51 & 52.88 & 26.56 & 0.031277 & 5.020251 \\
\hline 21/11/2006 & $17: 00$ & 27.09 & 27.63 & 0.77 & 0.902 & 59.63 & 55.53 & 26.79 & -0.14498 & 5.435531 \\
\hline $21 / 11 / 2006$ & $17: 30$ & 27.17 & 26.21 & 0.53 & 1.266 & 59.8 & 61.34 & 26.75 & 0.035209 & 5.025664 \\
\hline $21 / 11 / 2006$ & $18: 00$ & 26.61 & 25.69 & 0.98 & 1.366 & 63.49 & 62.51 & 26.29 & -0.4471 & 9.170974 \\
\hline $22 / 11 / 2006$ & 8:00 & 23.36 & 24.78 & 0.11 & 0.459 & 60.15 & 51.76 & 22.69 & -0.72227 & 15.9779 \\
\hline 22/11/2006 & $8: 30$ & 23.96 & 25.28 & 0.1 & 0.733 & 59.23 & 49.01 & 23.17 & -0.50915 & 10.41955 \\
\hline $22 / 11 / 2006$ & 9:00 & 24.32 & 26.04 & 0.1 & 0.644 & 58.52 & 46.39 & 23.58 & -0.38894 & 8.1509 \\
\hline $22 / 11 / 2006$ & $9: 30$ & 24.7 & 26.89 & 0.12 & 0.461 & 57.05 & 44.36 & 23.89 & -0.3572 & 7.655268 \\
\hline $22 / 11 / 2006$ & $10: 00$ & 24.84 & 27.69 & 0.37 & 0.207 & 55.72 & 39.42 & 24.11 & -0.82496 & 19.35529 \\
\hline $22 / 11 / 2006$ & $10: 30$ & 25.03 & 27.72 & 0.27 & 0.507 & 54.77 & 38.53 & 24.41 & -0.58627 & 12.20368 \\
\hline $22 / 11 / 2006$ & $11: 00$ & 25.57 & 28.12 & 0.45 & 0.412 & 48.47 & 38.47 & 24.89 & -0.68048 & 14.73281 \\
\hline $22 / 11 / 2006$ & $11: 30$ & 26.08 & 28.71 & 0.34 & 0.954 & 48.06 & 39.28 & 25.36 & -0.35512 & 7.62422 \\
\hline $22 / 11 / 2006$ & $12: 00$ & 26.5 & 28.71 & 0.42 & 1.363 & 46.9 & 38.67 & 25.79 & -0.2889 & 6.733844 \\
\hline $22 / 11 / 2006$ & $12: 30$ & 26.96 & 29.3 & 0.41 & 0.843 & 46.35 & 37.98 & 26.37 & -0.08254 & 5.141073 \\
\hline $22 / 11 / 2006$ & $13: 00$ & 27.27 & 29.71 & 0.29 & 1.156 & 45.51 & 40.23 & 26.63 & 0.156784 & 5.509397 \\
\hline $22 / 11 / 2006$ & $13: 30$ & 27.45 & 30.27 & 0.33 & 1.62 & 46.13 & 39.33 & 26.91 & 0.199093 & 5.821954 \\
\hline $22 / 11 / 2006$ & $14: 00$ & 28.01 & 30.4 & 0.51 & 1.499 & 46.47 & 37.78 & 27.42 & 0.266281 & 6.472273 \\
\hline $22 / 11 / 2006$ & $14: 30$ & 28.36 & 29.3 & 0.83 & 0.911 & 46.21 & 40.52 & 27.89 & 0.258361 & 6.385755 \\
\hline $22 / 11 / 2006$ & $15: 00$ & 28.35 & 30.13 & 0.83 & 0.688 & 46.5 & 40.79 & 28.11 & 0.283759 & 6.672541 \\
\hline $22 / 11 / 2006$ & $15: 30$ & 28.16 & 30.07 & 0.45 & 0.93 & 48.8 & 40.6 & 27.78 & 0.420245 & 8.681936 \\
\hline $22 / 11 / 2006$ & $16: 00$ & 28.61 & 29.92 & 0.57 & 1.041 & 48.35 & 39.68 & 28.1 & 0.509518 & 10.42749 \\
\hline $22 / 11 / 2006$ & $16: 30$ & 28.3 & 30.45 & 0.6 & 1.07 & 48 & 36.47 & 27.91 & 0.37188 & 7.879163 \\
\hline $22 / 11 / 2006$ & $17: 00$ & 28.66 & 29.74 & 0.61 & 1.757 & 45.53 & 37.01 & 28.22 & 0.492289 & 10.06386 \\
\hline $22 / 11 / 2006$ & $17: 30$ & 29.05 & 29.1 & 0.88 & 1.186 & 43.42 & 39.76 & 28.51 & 0.516843 & 10.58598 \\
\hline $22 / 11 / 2006$ & $18: 00$ & 28.56 & 28.18 & 0.43 & 1.257 & 44.68 & 42.2 & 28.18 & 0.561788 & 11.60932 \\
\hline 23/11/2006 & $8: 00$ & 25.21 & 26.44 & 0.13 & 0.86 & 50.44 & 42.49 & 24.32 & -0.27851 & 6.610986 \\
\hline 23/11/2006 & $8: 30$ & 25.87 & 26.34 & 0.11 & 0.83 & 49.52 & 46.78 & 24.89 & -0.01903 & 5.007494 \\
\hline 23/11/2006 & 9:00 & 26.24 & 27.04 & 0.14 & 1.262 & 48.84 & 40.44 & 25.29 & 0.023012 & 5.010962 \\
\hline 23/11/2006 & $9: 30$ & 26.41 & 27.57 & 0.16 & 1.279 & 50.24 & 38.21 & 25.56 & 0.062134 & 5.07993 \\
\hline 23/11/2006 & $10: 00$ & 26.54 & 28.23 & 0.14 & 1.346 & 47.65 & 37.02 & 25.73 & 0.137331 & 5.390736 \\
\hline $23 / 11 / 2006$ & $10: 30$ & 26.77 & 28.88 & 0.18 & 1.043 & 46.09 & 35.06 & 25.94 & 0.117288 & 5.284941 \\
\hline
\end{tabular}




\begin{tabular}{|c|c|c|c|c|c|c|c|c|c|c|}
\hline $23 / 11 / 2006$ & $11: 00$ & 27.05 & 29.17 & 0.16 & 1.335 & 43.72 & 32.92 & 26.21 & 0.233179 & 6.128201 \\
\hline $23 / 11 / 2006$ & $11: 30$ & 27.44 & 29.76 & 0.12 & 0.888 & 42.38 & 33.11 & 26.51 & 0.425929 & 8.782856 \\
\hline $23 / 11 / 2006$ & $12: 00$ & 27.78 & 30 & 0.11 & 1.083 & 41.13 & 32.24 & 26.86 & 0.552616 & 11.39336 \\
\hline $23 / 11 / 2006$ & $12: 30$ & 27.99 & 30.46 & 0.11 & 0.772 & 41.67 & 31.92 & 27.03 & 0.620748 & 13.08458 \\
\hline $23 / 11 / 2006$ & $13: 00$ & 28.3 & 30.46 & 0.14 & 0.692 & 41.51 & 32.33 & 27.35 & 0.667052 & 14.34893 \\
\hline $23 / 11 / 2006$ & $13: 30$ & 28.56 & 31.19 & 0.12 & 0.721 & 40.2 & 30.44 & 27.59 & 0.776232 & 17.69671 \\
\hline $23 / 11 / 2006$ & $14: 00$ & 28.76 & 31.46 & 0.14 & 0.88 & 40.62 & 30.02 & 27.84 & 0.821738 & 19.24253 \\
\hline $23 / 11 / 2006$ & $14: 30$ & 29.13 & 30.81 & 0.14 & 0.711 & 40.16 & 31.28 & 28.2 & 0.943368 & 23.79686 \\
\hline $23 / 11 / 2006$ & $15: 00$ & 29.4 & 31.32 & 0.15 & 0.853 & 39.44 & 31.43 & 28.48 & 1.017753 & 26.8731 \\
\hline $23 / 11 / 2006$ & $15: 30$ & 29.66 & 31.11 & 0.13 & 0.873 & 39.06 & 32 & 28.76 & 1.133662 & 32.07174 \\
\hline $23 / 11 / 2006$ & $16: 00$ & 29.47 & 31.29 & 0.13 & 1.495 & 39.49 & 30.97 & 28.53 & 1.066587 & 29.00574 \\
\hline $23 / 11 / 2006$ & $16: 30$ & 29.58 & 31.12 & 0.12 & 1.418 & 40.04 & 30.02 & 28.62 & 1.120663 & 31.4657 \\
\hline $23 / 11 / 2006$ & $17: 00$ & 29.89 & 30.82 & 0.17 & 1.367 & 38.2 & 29.13 & 28.98 & 1.155949 & 33.12348 \\
\hline $23 / 11 / 2006$ & $17: 30$ & 29.88 & 30.31 & 0.18 & 1.271 & 37.15 & 29.78 & 29 & 1.136173 & 32.18943 \\
\hline $23 / 11 / 2006$ & $18: 00$ & 29.98 & 29.66 & 0.16 & 0.969 & 35.93 & 31 & 29.03 & 1.169558 & 33.7734 \\
\hline $24 / 11 / 2006$ & $8: 00$ & 24.37 & 24.43 & 0.39 & 2.042 & 67.81 & 65.76 & 23.95 & -0.91208 & 22.56778 \\
\hline $24 / 11 / 2006$ & $8: 30$ & 24.79 & 25.16 & 0.42 & 2.012 & 67.79 & 63.23 & 24.39 & -0.78 & 17.82143 \\
\hline $24 / 11 / 2006$ & 9:00 & 24.95 & 25.63 & 0.48 & 1.908 & 67.29 & 61.87 & 24.63 & -0.78026 & 17.82999 \\
\hline $24 / 11 / 2006$ & $9: 30$ & 25.38 & 26.4 & 0.5 & 1.829 & 65.93 & 59.7 & 24.99 & -0.64118 & 13.63114 \\
\hline $24 / 11 / 2006$ & $10: 00$ & 25.6 & 27.29 & 0.54 & 2.014 & 65.95 & 55.88 & 25.29 & -0.5779 & 11.99752 \\
\hline $24 / 11 / 2006$ & $10: 30$ & 26.17 & 27.8 & 0.57 & 1.935 & 64.42 & 55.35 & 25.72 & -0.39064 & 8.178647 \\
\hline $24 / 11 / 2006$ & $11: 00$ & 26.74 & 28.6 & 0.61 & 1.572 & 61.72 & 52.99 & 26.22 & -0.20607 & 5.880657 \\
\hline $24 / 11 / 2006$ & $11: 30$ & 26.96 & 29.54 & 0.54 & 1.345 & 61.94 & 49.97 & 26.56 & -0.04156 & 5.035751 \\
\hline $24 / 11 / 2006$ & $12: 00$ & 27.68 & 29.75 & 0.48 & 1.339 & 59.08 & 47.32 & 27.07 & 0.25883 & 6.390807 \\
\hline $24 / 11 / 2006$ & $12: 30$ & 28.29 & 30.64 & 0.4 & 1.432 & 57.29 & 44.56 & 27.67 & 0.557236 & 11.50169 \\
\hline $24 / 11 / 2006$ & $13: 00$ & 28.94 & 30.57 & 0.36 & 0.927 & 53.95 & 45.14 & 28.34 & 0.824399 & 19.33562 \\
\hline $24 / 11 / 2006$ & $13: 30$ & 29.31 & 30.71 & 0.34 & 0.877 & 51.32 & 42.84 & 28.56 & 0.942 & 23.74231 \\
\hline $24 / 11 / 2006$ & $14: 00$ & 29.27 & 30.96 & 0.3 & 0.588 & 51.45 & 40.7 & 28.58 & 0.966525 & 24.73159 \\
\hline $24 / 11 / 2006$ & $14: 30$ & 29.75 & 32.54 & 0.28 & 0.689 & 49.81 & 33.74 & 29.05 & 1.152065 & 32.93907 \\
\hline $24 / 11 / 2006$ & $15: 00$ & 29.77 & 31.56 & 0.33 & 0.398 & 47.97 & 34.74 & 29 & 1.096451 & 30.35188 \\
\hline $24 / 11 / 2006$ & $15: 30$ & 30.32 & 31.03 & 0.31 & 0.196 & 42.98 & 36.03 & 29.72 & 1.299386 & 40.23684 \\
\hline $24 / 11 / 2006$ & $16: 00$ & 30.09 & 32.41 & 0.33 & 0.179 & 40.96 & 30.62 & 29.32 & 1.152824 & 32.97504 \\
\hline $24 / 11 / 2006$ & $16: 30$ & 29.96 & 32.1 & 0.16 & 0.942 & 42.47 & 34.81 & 29.09 & 1.240182 & 37.23379 \\
\hline $24 / 11 / 2006$ & $17: 00$ & 30.56 & 29.89 & 0.26 & 0.664 & 39.53 & 39.49 & 29.74 & 1.355789 & 43.17093 \\
\hline $24 / 11 / 2006$ & $17: 30$ & 30.09 & 30.96 & 0.23 & 0.506 & 44.93 & 36.64 & 29.41 & 1.275661 & 39.02317 \\
\hline $24 / 11 / 2006$ & $18: 00$ & 29.62 & 30.58 & 0.17 & 0.787 & 45.98 & 39.45 & 28.83 & 1.154696 & 33.06392 \\
\hline
\end{tabular}


Ambiente: Ante-sala da Congregação

Período 2: 12 a 15 de março de 2007

\begin{tabular}{|c|c|c|c|c|c|c|c|c|c|c|}
\hline Data & Hora & Temp. int. & Temp. ext. & Vel. int. & Vel. ext. & UR int. & UR ext. & $\begin{array}{l}\text { Temp. } \\
\text { Globo int. }\end{array}$ & PMV & PPD \\
\hline $12 / 3 / 2007$ & 8:00 & 25.29 & 22.71 & 0.43 & 0.833 & 70.61 & 80.2 & 25.47 & -0.49042 & 10.0253 \\
\hline $12 / 3 / 2007$ & $8: 30$ & 25.02 & 23.17 & 0.39 & 0.874 & 72.46 & 78.7 & 24.94 & -0.57 & 11.8058 \\
\hline $12 / 3 / 2007$ & 9:00 & 25.85 & 24.44 & 0.39 & 0.685 & 67.44 & 71.3 & 25.64 & -0.28778 & 6.72038 \\
\hline $12 / 3 / 2007$ & 9:30 & 26.61 & 26.49 & 0.48 & 1.371 & 63.43 & 62.41 & 26.41 & -0.10033 & 5.20845 \\
\hline $12 / 3 / 2007$ & $10: 00$ & 27.38 & 26.89 & 0.38 & 1.284 & 63.24 & 60.91 & 27.02 & 0.29128 & 6.76274 \\
\hline $12 / 3 / 2007$ & $10: 30$ & 27.7 & 27.28 & 0.45 & 1.275 & 60.46 & 58.37 & 27.37 & 0.33979 & 7.40158 \\
\hline $12 / 3 / 2007$ & $11: 00$ & 28.48 & 28.56 & 0.55 & 1.374 & 53.43 & 52.07 & 28.11 & 0.53034 & 10.8842 \\
\hline $12 / 3 / 2007$ & $11: 30$ & 28.81 & 28.79 & 0.59 & 1.808 & 50.74 & 49.11 & 28.52 & 0.63453 & 13.4512 \\
\hline $12 / 3 / 2007$ & $12: 00$ & 29.44 & 29.52 & 0.47 & 1.402 & 49.43 & 46.89 & 28.98 & 0.93344 & 23.4027 \\
\hline $12 / 3 / 2007$ & $12: 30$ & 29.67 & 29.98 & 0.59 & 1.565 & 46.92 & 43.09 & 29.39 & 0.97032 & 24.8868 \\
\hline $12 / 3 / 2007$ & $13: 00$ & 30.15 & 30.16 & 0.51 & 1.545 & 46.71 & 43.47 & 29.77 & 1.1958 & 35.0422 \\
\hline $12 / 3 / 2007$ & $13: 30$ & 30.28 & 30.58 & 0.47 & 1.595 & 45.94 & 41.56 & 29.88 & 1.25776 & 38.1163 \\
\hline $12 / 3 / 2007$ & $14: 00$ & 30.69 & 31 & 0.57 & 1.538 & 42.74 & 39.2 & 30.4 & 1.37357 & 44.1087 \\
\hline $12 / 3 / 2007$ & $14: 30$ & 31.11 & 31.06 & 0.37 & 1.654 & 42.36 & 38.12 & 30.7 & 1.60329 & 56.5242 \\
\hline $12 / 3 / 2007$ & $15: 00$ & 31.14 & 30.61 & 0.17 & 1.27 & 42.87 & 40.82 & 30.57 & 1.70413 & 61.9727 \\
\hline $12 / 3 / 2007$ & $15: 30$ & 31.44 & 31.35 & 0.16 & 1.155 & 41.76 & 37.65 & 30.96 & 1.82122 & 68.1111 \\
\hline $12 / 3 / 2007$ & $16: 00$ & 31.66 & 31.75 & 0.15 & 1.072 & 40.6 & 35.41 & 31.05 & 1.87309 & 70.7276 \\
\hline $12 / 3 / 2007$ & $16: 30$ & 31.09 & 30.66 & 0.15 & 1.219 & 42.09 & 38.4 & 30.52 & 1.69327 & 61.3913 \\
\hline $12 / 3 / 2007$ & $17: 00$ & 31.04 & 31.1 & 0.14 & 0.824 & 41.98 & 36.72 & 30.39 & 1.67019 & 60.1499 \\
\hline $12 / 3 / 2007$ & $17: 30$ & 30.91 & 30.94 & 0.12 & 0.802 & 42.5 & 37.26 & 30.3 & 1.65556 & 59.3604 \\
\hline $12 / 3 / 2007$ & $18: 00$ & 30.51 & 30.41 & 0.13 & 0.58 & 42.43 & 37.53 & 29.84 & 1.49659 & 50.7152 \\
\hline $13 / 3 / 2007$ & 8:00 & 26.47 & 23.51 & 0.22 & 0.282 & 65.46 & 75.5 & 26.02 & 0.15042 & 5.46884 \\
\hline $13 / 3 / 2007$ & $8: 30$ & 25.94 & 25.29 & 0.3 & 0.433 & 65.96 & 65.39 & 25.61 & -0.15942 & 5.52666 \\
\hline $13 / 3 / 2007$ & 9:00 & 26.64 & 26.71 & 0.29 & 0.527 & 61.83 & 57.83 & 26.07 & 0.07048 & 5.10286 \\
\hline $13 / 3 / 2007$ & $9: 30$ & 27.04 & 27.01 & 0.31 & 0.821 & 59.66 & 56.47 & 26.6 & 0.19112 & 5.75738 \\
\hline $13 / 3 / 2007$ & $10: 00$ & 27.61 & 28.23 & 0.46 & 0.672 & 55.95 & 52.49 & 27.29 & 0.26474 & 6.45522 \\
\hline $13 / 3 / 2007$ & $10: 30$ & 27.91 & 28.02 & 0.56 & 1.005 & 55.17 & 53.32 & 27.87 & 0.33773 & 7.37242 \\
\hline $13 / 3 / 2007$ & $11: 00$ & 28.03 & 27.78 & 0.63 & 1.352 & 54.5 & 52.71 & 28.07 & 0.34876 & 7.53069 \\
\hline $13 / 3 / 2007$ & $11: 30$ & 28.56 & 28.06 & 0.37 & 1.108 & 54.5 & 53.17 & 28.18 & 0.69845 & 15.259 \\
\hline $13 / 3 / 2007$ & $12: 00$ & 29.11 & 29.02 & 0.52 & 1.291 & 50.98 & 48.66 & 28.76 & 0.79591 & 18.3544 \\
\hline $13 / 3 / 2007$ & $12: 30$ & 29.66 & 29.17 & 0.57 & 1.385 & 49.98 & 47.88 & 29.3 & 0.99483 & 25.9023 \\
\hline $13 / 3 / 2007$ & $13: 00$ & 29.78 & 29.72 & 0.44 & 1.285 & 48.39 & 45.26 & 29.65 & 1.10966 & 30.9572 \\
\hline $13 / 3 / 2007$ & $13: 30$ & 30.73 & 30.6 & 0.42 & 0.877 & 45.59 & 41.31 & 30.31 & 1.46027 & 48.7476 \\
\hline $13 / 3 / 2007$ & $14: 00$ & 30.75 & 30.99 & 0.45 & 1.073 & 46.45 & 41.36 & 30.3 & 1.47271 & 49.4201 \\
\hline $13 / 3 / 2007$ & $14: 30$ & 30.62 & 30.66 & 0.42 & 1.101 & 44.23 & 40.67 & 30.52 & 1.44468 & 47.9065 \\
\hline $13 / 3 / 2007$ & $15: 00$ & 30.42 & 30.67 & 0.38 & 0.99 & 43.71 & 39.94 & 30.33 & 1.36426 & 43.617 \\
\hline $13 / 3 / 2007$ & $15: 30$ & 30.32 & 30.7 & 0.4 & 0.829 & 46.05 & 40.95 & 30.17 & 1.34322 & 42.5114 \\
\hline $13 / 3 / 2007$ & $16: 00$ & 30.3 & 30.94 & 0.43 & 0.502 & 42.41 & 38.13 & 30.18 & 1.26295 & 38.3784 \\
\hline $13 / 3 / 2007$ & $16: 30$ & 30.93 & 31.85 & 0.37 & 0.377 & 41.46 & 34.82 & 30.53 & 1.52265 & 52.1319 \\
\hline $13 / 3 / 2007$ & $17: 00$ & 30.52 & 31.15 & 0.33 & 0.74 & 42.28 & 36.17 & 30.25 & 1.39493 & 45.2418 \\
\hline $13 / 3 / 2007$ & $17: 30$ & 30.2 & 30.72 & 0.34 & 0.604 & 44.31 & 38.62 & 29.84 & 1.28162 & 39.3268 \\
\hline $13 / 3 / 2007$ & $18: 00$ & 29.53 & 29.11 & 0.19 & 0.747 & 50.14 & 47.76 & 29.03 & 1.17111 & 33.8479 \\
\hline $14 / 3 / 2007$ & 8:00 & 26.4 & 24.31 & 0.16 & 0.463 & 62.24 & 68.04 & 25.98 & 0.22048 & 6.00841 \\
\hline $14 / 3 / 2007$ & $8: 30$ & 26.72 & 24.62 & 0.25 & 0.62 & 61.54 & 66.94 & 26.42 & 0.18511 & 5.71039 \\
\hline $14 / 3 / 2007$ & 9:00 & 25.76 & 25.3 & 0.44 & 0.661 & 66.37 & 65.59 & 25.7 & -0.37166 & 7.87577 \\
\hline $14 / 3 / 2007$ & 9:30 & 26.22 & 25.87 & 0.4 & 1.039 & 65.13 & 62.77 & 26.05 & -0.1619 & 5.54321 \\
\hline $14 / 3 / 2007$ & $10: 00$ & 26.97 & 26.45 & 0.44 & 1.097 & 62.61 & 60.53 & 26.83 & 0.0888 & 5.1633 \\
\hline $14 / 3 / 2007$ & $10: 30$ & 27.18 & 27.32 & 0.56 & 0.954 & 61.6 & 58.33 & 27.09 & 0.07367 & 5.11239 \\
\hline
\end{tabular}




\begin{tabular}{|c|c|c|c|c|c|c|c|c|c|c|}
\hline $14 / 3 / 2007$ & $11: 00$ & 27.92 & 27.76 & 0.43 & 1.133 & 58.36 & 56.15 & 27.87 & 0.46657 & 9.54493 \\
\hline $14 / 3 / 2007$ & $11: 30$ & 28.28 & 28.03 & 0.5 & 1.148 & 57.43 & 54.62 & 28.06 & 0.53332 & 10.9511 \\
\hline $14 / 3 / 2007$ & $12: 00$ & 28.28 & 28.59 & 0.59 & 1.185 & 56.27 & 52.78 & 28.12 & 0.47269 & 9.66581 \\
\hline $14 / 3 / 2007$ & $12: 30$ & 29.33 & 29.04 & 0.53 & 1.499 & 51.6 & 50.22 & 29.24 & 0.92388 & 23.0266 \\
\hline $14 / 3 / 2007$ & 13:00 & 29 & 29.06 & 0.71 & 1.535 & 54.89 & 51.02 & 29.04 & 0.74036 & 16.5401 \\
\hline $14 / 3 / 2007$ & $13: 30$ & 29.91 & 29.64 & 0.47 & 1.15 & 54.57 & 51.85 & 29.8 & 1.22797 & 36.6256 \\
\hline $14 / 3 / 2007$ & $14: 00$ & 29.85 & 30.27 & 0.46 & 1.57 & 51.45 & 46.91 & 29.84 & 1.19035 & 34.7772 \\
\hline $14 / 3 / 2007$ & $14: 30$ & 28.32 & 28.86 & 0.56 & 1.331 & 56.42 & 50.48 & 28.16 & 0.50974 & 10.4322 \\
\hline $14 / 3 / 2007$ & $15: 00$ & 28.71 & 27.48 & 0.15 & 1.021 & 52.91 & 55.18 & 28.07 & 0.9461 & 23.906 \\
\hline $14 / 3 / 2007$ & $15: 30$ & 28.65 & 26.59 & 0.18 & 0.15 & 55.2 & 61.47 & 27.98 & 0.89717 & 21.9957 \\
\hline $14 / 3 / 2007$ & $16: 00$ & 28.59 & 26.11 & 0.18 & 0.006 & 58.03 & 68.08 & 27.84 & 0.88938 & 21.7006 \\
\hline $14 / 3 / 2007$ & $16: 30$ & 28.29 & 25.37 & 0.22 & 0.129 & 59.52 & 69.83 & 27.66 & 0.75638 & 17.05 \\
\hline $14 / 3 / 2007$ & $17: 00$ & 27.89 & 25.72 & 0.24 & 0.412 & 60.98 & 68.7 & 27.44 & 0.61835 & 13.0217 \\
\hline $14 / 3 / 2007$ & $17: 30$ & 27.55 & 25.13 & 0.28 & 0.069 & 61.72 & 69.3 & 27 & 0.42928 & 8.84306 \\
\hline $14 / 3 / 2007$ & $18: 00$ & 27.12 & 24.54 & 0.25 & 0.322 & 61.03 & 67.5 & 26.54 & 0.29318 & 6.78583 \\
\hline $15 / 3 / 2007$ & 8:00 & 25.59 & 22.6 & 0.21 & 0.106 & 64.72 & 75.8 & 24.96 & -0.18984 & 5.74721 \\
\hline $15 / 3 / 2007$ & $8: 30$ & 25.61 & 23.84 & 0.23 & 0.075 & 66.12 & 72.9 & 25.11 & -0.19182 & 5.7629 \\
\hline $15 / 3 / 2007$ & 9:00 & 26.25 & 25.15 & 0.16 & 0.014 & 64.41 & 68.73 & 25.57 & 0.14563 & 5.43945 \\
\hline $15 / 3 / 2007$ & 9:30 & 25.78 & 26.27 & 0.32 & 0.469 & 65.01 & 60.19 & 25.36 & -0.27104 & 6.52547 \\
\hline $15 / 3 / 2007$ & $10: 00$ & 26.23 & 26.91 & 0.37 & 0.713 & 64.02 & 59.22 & 25.8 & -0.16638 & 5.57372 \\
\hline $15 / 3 / 2007$ & $10: 30$ & 26.75 & 27.02 & 0.66 & 1.549 & 60.26 & 57.42 & 26.51 & -0.21481 & 5.95714 \\
\hline $15 / 3 / 2007$ & $11: 00$ & 27.11 & 27.21 & 0.61 & 1.793 & 60.55 & 57.3 & 26.92 & -0.01412 & 5.00413 \\
\hline $15 / 3 / 2007$ & $11: 30$ & 27.63 & 27.51 & 0.63 & 1.927 & 60.38 & 57.31 & 27.3 & 0.18075 & 5.6773 \\
\hline $15 / 3 / 2007$ & $12: 00$ & 27.95 & 27.85 & 0.51 & 2.027 & 60.83 & 57.94 & 27.63 & 0.40379 & 8.39764 \\
\hline $15 / 3 / 2007$ & $12: 30$ & 28.09 & 27.79 & 0.62 & 1.921 & 59.68 & 57.57 & 27.81 & 0.3883 & 8.14054 \\
\hline $15 / 3 / 2007$ & $13: 00$ & 28.01 & 28.1 & 0.77 & 2.405 & 59 & 55.93 & 28.01 & 0.30013 & 6.87178 \\
\hline $15 / 3 / 2007$ & $13: 30$ & 28.1 & 28.01 & 0.54 & 1.821 & 59.9 & 56.86 & 27.92 & 0.45696 & 9.35825 \\
\hline $15 / 3 / 2007$ & $14: 00$ & 28.25 & 28.56 & 0.67 & 2.491 & 58.2 & 55.17 & 28.04 & 0.42615 & 8.78678 \\
\hline $15 / 3 / 2007$ & $14: 30$ & 29.15 & 29.13 & 0.52 & 2.063 & 58.78 & 55.27 & 28.8 & 0.88725 & 21.6203 \\
\hline $15 / 3 / 2007$ & $15: 00$ & 27.54 & 27.76 & 0.58 & 2.26 & 63.39 & 60.56 & 27.66 & 0.25669 & 6.36785 \\
\hline $15 / 3 / 2007$ & $15: 30$ & 27.59 & 27.62 & 0.56 & 1.259 & 57.05 & 56.54 & 27.39 & 0.19667 & 5.80206 \\
\hline $15 / 3 / 2007$ & $16: 00$ & 28.12 & 28.6 & 0.37 & 1.519 & 59.03 & 53.87 & 27.71 & 0.55753 & 11.5085 \\
\hline $15 / 3 / 2007$ & $16: 30$ & 28.43 & 28.97 & 0.47 & 1.365 & 57.87 & 53.3 & 28.18 & 0.61747 & 12.9987 \\
\hline $15 / 3 / 2007$ & $17: 00$ & 27.91 & 28.02 & 0.5 & 1.242 & 57.51 & 54.11 & 27.65 & 0.37232 & 7.88609 \\
\hline $15 / 3 / 2007$ & $17: 30$ & 27.9 & 28.44 & 0.4 & 1.06 & 58.66 & 53.55 & 27.59 & 0.45164 & 9.2566 \\
\hline $15 / 3 / 2007$ & 18:00 & 27.48 & 28.05 & 0.54 & 0.839 & 58.94 & 54.28 & 27.2 & 0.17025 & 5.60074 \\
\hline
\end{tabular}


Ambiente: Ante-sala da Congregação

Período 3: 31 de maio a 03 de junho de 2007

\begin{tabular}{|c|c|c|c|c|c|c|c|c|c|c|}
\hline Data & Hora & Temp. int. & Temp. ext. & Vel. int. & Vel. ext. & UR int. & UR ext. & $\begin{array}{c}\text { Temp. } \\
\text { Globo int. }\end{array}$ & PMV & PPD \\
\hline $31 / 5 / 2007$ & 8:00 & 14.2 & 9.97 & 0.22 & 0.497 & 63.1 & 74.6 & 13.6 & -2.72221 & 97.00225 \\
\hline $31 / 5 / 2007$ & $8: 30$ & 14.56 & 12 & 0.25 & 0.326 & 62.5 & 66.91 & 13.92 & -2.70429 & 96.78749 \\
\hline $31 / 5 / 2007$ & 9:00 & 15.36 & 13.59 & 0.22 & 0.677 & 60.99 & 61.82 & 14.68 & -2.42378 & 91.69728 \\
\hline $31 / 5 / 2007$ & $9: 30$ & 16.1 & 14.91 & 0.24 & 1.127 & 59.58 & 58.47 & 15.4 & -2.27544 & 87.48656 \\
\hline $31 / 5 / 2007$ & $10: 00$ & 16.91 & 15.87 & 0.18 & 1.458 & 57.8 & 55.43 & 16.14 & -1.92585 & 73.30492 \\
\hline $31 / 5 / 2007$ & 10:30 & 17.8 & 16.68 & 0.21 & 1.738 & 55.73 & 52.61 & 16.93 & -1.77856 & 65.90704 \\
\hline $31 / 5 / 2007$ & 11:00 & 18.48 & 17.37 & 0.16 & 1.731 & 54.36 & 52.02 & 17.66 & -1.47708 & 49.65692 \\
\hline $31 / 5 / 2007$ & 11:30 & 19.27 & 17.83 & 0.2 & 1.492 & 53.03 & 51.79 & 18.46 & -1.36364 & 43.58415 \\
\hline $31 / 5 / 2007$ & $12: 00$ & 19.98 & 18.6 & 0.18 & 1.417 & 52.51 & 51.4 & 19.36 & -1.11067 & 31.0036 \\
\hline $31 / 5 / 2007$ & $12: 30$ & 20.67 & 19.17 & 0.21 & 1.62 & 51.76 & 50.66 & 19.97 & -0.99395 & 25.86558 \\
\hline $31 / 5 / 2007$ & 13:00 & 21.2 & 19.93 & 0.17 & 1.032 & 51.29 & 49.63 & 20.57 & -0.76759 & 17.41294 \\
\hline $31 / 5 / 2007$ & $13: 30$ & 21.58 & 20.65 & 0.14 & 1.036 & 50.92 & 48.88 & 21.06 & -0.59058 & 12.31092 \\
\hline $31 / 5 / 2007$ & 14:00 & 22.13 & 21.22 & 0.16 & 0.965 & 50.08 & 47 & 21.61 & -0.49121 & 10.04143 \\
\hline $31 / 5 / 2007$ & $14: 30$ & 22.18 & 21.69 & 0.17 & 0.826 & 50.05 & 46.72 & 21.76 & -0.48597 & 9.933738 \\
\hline $31 / 5 / 2007$ & 15:00 & 22.27 & 22.04 & 0.16 & 0.753 & 50.34 & 46 & 21.85 & -0.44049 & 9.047687 \\
\hline $31 / 5 / 2007$ & $15: 30$ & 22.12 & 21.82 & 0.14 & 0.745 & 50.81 & 46.39 & 21.69 & -0.43724 & 8.987767 \\
\hline $31 / 5 / 2007$ & $16: 00$ & 21.84 & 21.79 & 0.13 & 0.663 & 51.74 & 46.96 & 21.36 & -0.48872 & 9.990155 \\
\hline $31 / 5 / 2007$ & 16:30 & 21.36 & 21.78 & 0.12 & 0.478 & 52.79 & 46.98 & 20.71 & -0.60284 & 12.6206 \\
\hline $31 / 5 / 2007$ & 17:00 & 20.51 & 21.13 & 0.13 & 0.332 & 55.21 & 49.65 & 19.75 & -0.8509 & 20.27894 \\
\hline $31 / 5 / 2007$ & $17: 30$ & 19.68 & 20.49 & 0.17 & 0.066 & 57.95 & 52.16 & 18.87 & -1.16052 & 33.34118 \\
\hline $31 / 5 / 2007$ & 18:00 & 18.98 & 19.42 & 0.16 & 0.023 & 60.1 & 56.31 & 18.1 & -1.32104 & 41.35567 \\
\hline 1/6/2007 & $8: 00$ & 17.05 & 14.93 & 0.27 & 0.102 & 76.24 & 83.4 & 16.32 & -1.99814 & 76.67766 \\
\hline 1/6/2007 & $8: 30$ & 17.35 & 16.49 & 0.16 & 0.425 & 77.29 & 77.7 & 16.6 & -1.66069 & 59.63725 \\
\hline 1/6/2007 & $9: 00$ & 18.25 & 18.13 & 0.15 & 0.799 & 75.7 & 72.6 & 17.39 & -1.40926 & 46.00599 \\
\hline $1 / 6 / 2007$ & $9: 30$ & 19.1 & 19.55 & 0.15 & 0.964 & 73.4 & 67.87 & 18.18 & -1.19813 & 35.15623 \\
\hline $1 / 6 / 2007$ & $10: 00$ & 19.9 & 20.08 & 0.19 & 1.208 & 71.26 & 66.21 & 18.98 & -1.08292 & 29.73796 \\
\hline 1/6/2007 & 10:30 & 20.57 & 20.94 & 0.2 & 1.23 & 69.59 & 64.08 & 19.68 & -0.92131 & 22.92641 \\
\hline 1/6/2007 & 11:00 & 21.61 & 21.71 & 0.19 & 1.3 & 67.44 & 62.6 & 20.63 & -0.63373 & 13.42973 \\
\hline $1 / 6 / 2007$ & $11: 30$ & 22.16 & 22.53 & 0.21 & 1.418 & 66.14 & 60.51 & 21.31 & -0.50575 & 10.34678 \\
\hline 1/6/2007 & 12:00 & 23.02 & 22.96 & 0.24 & 1.658 & 63.98 & 59.5 & 22.19 & -0.3129 & 7.03515 \\
\hline $1 / 6 / 2007$ & $12: 30$ & 23.58 & 23.62 & 0.24 & 1.748 & 62.55 & 57.61 & 22.81 & -0.1541 & 5.492088 \\
\hline $1 / 6 / 2007$ & 13:00 & 24.04 & 24.33 & 0.2 & 1.375 & 61.39 & 56.2 & 23.29 & 0.022758 & 5.010722 \\
\hline 1/6/2007 & 13:30 & 24.44 & 25.18 & 0.18 & 1.27 & 61.02 & 54.36 & 23.71 & 0.163724 & 5.555548 \\
\hline $1 / 6 / 2007$ & $14: 00$ & 24.71 & 25.92 & 0.21 & 1.414 & 60.6 & 52.72 & 23.98 & 0.198146 & 5.814145 \\
\hline 1/6/2007 & 14:30 & 25.04 & 26.07 & 0.19 & 1.775 & 58.75 & 51.45 & 24.34 & 0.306601 & 6.953714 \\
\hline 1/6/2007 & 15:00 & 25.2 & 26.24 & 0.15 & 1.733 & 58.53 & 50.54 & 24.5 & 0.404628 & 8.411779 \\
\hline $1 / 6 / 2007$ & $15: 30$ & 25.22 & 26.5 & 0.18 & 1.482 & 58.23 & 49.68 & 24.52 & 0.366839 & 7.801236 \\
\hline 1/6/2007 & 16:00 & 25.03 & 26.41 & 0.14 & 1.599 & 58.79 & 50.15 & 24.33 & 0.374982 & 7.92765 \\
\hline 1/6/2007 & $16: 30$ & 24.64 & 26.5 & 0.15 & 1.18 & 59.92 & 50 & 23.85 & 0.249268 & 6.28968 \\
\hline $1 / 6 / 2007$ & 17:00 & 23.99 & 25.96 & 0.18 & 1.445 & 62.03 & 51.72 & 23.23 & 0.040648 & 5.034206 \\
\hline 1/6/2007 & 17:30 & 23.27 & 25.5 & 0.19 & 1.008 & 64.25 & 53.12 & 22.38 & -0.17703 & 5.649644 \\
\hline 1/6/2007 & 18:00 & 22.46 & 24.37 & 0.19 & 0.615 & 67.49 & 57.62 & 21.51 & -0.39105 & 8.185401 \\
\hline 2/6/2007 & $8: 00$ & 19.4 & 17.78 & 0.24 & 0.456 & 87.19 & 95.4 & 18.61 & -1.21946 & 36.20379 \\
\hline $2 / 6 / 2007$ & $8: 30$ & 19.64 & 18.05 & 0.14 & 0.66 & 86.2 & 95.2 & 18.78 & -0.95003 & 24.06373 \\
\hline $2 / 6 / 2007$ & $9: 00$ & 20.29 & 18.62 & 0.12 & 0.153 & 84.83 & 94.6 & 19.48 & -0.71975 & 15.90067 \\
\hline 2/6/2007 & $9: 30$ & 20.68 & 19.64 & 0.16 & 1.107 & 84.65 & 89.4 & 19.99 & -0.70075 & 15.32737 \\
\hline 2/6/2007 & 10:00 & 20.99 & 19.95 & 0.15 & 1.421 & 83.77 & 87.3 & 20.23 & -0.60465 & 12.66673 \\
\hline $2 / 6 / 2007$ & 10:30 & 21.39 & 20.29 & 0.19 & 1.275 & 82.53 & 84.8 & 20.71 & -0.57215 & 11.85762 \\
\hline
\end{tabular}




\begin{tabular}{|c|c|c|c|c|c|c|c|c|c|c|}
\hline $2 / 6 / 2007$ & $11: 00$ & 21.65 & 20.77 & 0.2 & 1.138 & 80.53 & 81.7 & 20.9 & -0.53503 & 10.9895 \\
\hline $2 / 6 / 2007$ & $11: 30$ & 21.46 & 21.07 & 0.16 & 0.688 & 80.57 & 79.7 & 20.83 & -0.4998 & 10.2208 \\
\hline $2 / 6 / 2007$ & $12: 00$ & 21.21 & 20.86 & 0.15 & 1.172 & 81.36 & 80.9 & 20.4 & -0.56332 & 11.64579 \\
\hline $2 / 6 / 2007$ & $12: 30$ & 20.86 & 19.86 & 0.19 & 1.532 & 84.62 & 87.1 & 20.15 & -0.71434 & 15.73588 \\
\hline $2 / 6 / 2007$ & 13:00 & 20.54 & 19.47 & 0.19 & 1.749 & 86.12 & 91.8 & 19.79 & -0.80123 & 18.53504 \\
\hline 2/6/2007 & $13: 30$ & 20.1 & 19.07 & 0.26 & 0.869 & 87.47 & 92 & 19.45 & -1.03212 & 27.49164 \\
\hline $2 / 6 / 2007$ & $14: 00$ & 20.1 & 19.05 & 0.26 & 0.441 & 86.89 & 90.8 & 19.49 & -1.0313 & 27.45578 \\
\hline 2/6/2007 & $14: 30$ & 19.82 & 18.8 & 0.28 & 0.514 & 88.33 & 91.6 & 19.22 & -1.13544 & 32.15517 \\
\hline 2/6/2007 & $15: 00$ & 19.96 & 18.48 & 0.22 & 0.881 & 87.33 & 93.4 & 19.2 & -1.01842 & 26.90168 \\
\hline $2 / 6 / 2007$ & $15: 30$ & 19.86 & 18.25 & 0.26 & 1.582 & 86.43 & 91.8 & 19.13 & -1.11648 & 31.27209 \\
\hline 2/6/2007 & $16: 00$ & 19.96 & 18.44 & 0.24 & 0.707 & 86.45 & 91.7 & 19.31 & -1.04642 & 28.11448 \\
\hline 2/6/2007 & $16: 30$ & 20.37 & 18.63 & 0.18 & 0.76 & 84.06 & 90.7 & 19.6 & -0.84276 & 19.98616 \\
\hline 2/6/2007 & $17: 00$ & 19.88 & 18.68 & 0.24 & 0.931 & 85.28 & 88.7 & 19.21 & -1.07817 & 29.52432 \\
\hline $2 / 6 / 2007$ & $17: 30$ & 19.67 & 18.25 & 0.23 & 0.68 & 86 & 90.6 & 18.96 & -1.12232 & 31.54278 \\
\hline $2 / 6 / 2007$ & $18: 00$ & 19.59 & 18.09 & 0.25 & 0.097 & 86.31 & 91.9 & 18.8 & -1.18598 & 34.56504 \\
\hline $3 / 6 / 2007$ & 8:00 & 18.6 & 16.84 & 0.26 & 1.467 & 87.72 & 94.4 & 17.9 & -1.47487 & 49.53683 \\
\hline $3 / 6 / 2007$ & $8: 30$ & 18.56 & 16.77 & 0.24 & 1.313 & 87.83 & 94.6 & 17.82 & -1.45399 & 48.40839 \\
\hline $3 / 6 / 2007$ & 9:00 & 18.55 & 16.64 & 0.26 & 1.151 & 87.56 & 94.7 & 17.82 & -1.49322 & 50.53203 \\
\hline $3 / 6 / 2007$ & 9:30 & 18.22 & 16.44 & 0.29 & 1.209 & 88.29 & 95 & 17.63 & -1.62329 & 57.61171 \\
\hline $3 / 6 / 2007$ & $10: 00$ & 18.38 & 16.27 & 0.24 & 0.911 & 87.46 & 95.5 & 17.65 & -1.50671 & 51.26466 \\
\hline $3 / 6 / 2007$ & $10: 30$ & 18.38 & 16.24 & 0.17 & 1.093 & 87.2 & 95.8 & 17.66 & -1.35445 & 43.10052 \\
\hline $3 / 6 / 2007$ & $11: 00$ & 18.44 & 16.05 & 0.2 & 1.62 & 86.03 & 95.7 & 17.82 & -1.40409 & 45.72986 \\
\hline $3 / 6 / 2007$ & $11: 30$ & 18.59 & 15.98 & 0.25 & 2.113 & 84.88 & 94.6 & 18 & -1.46343 & 48.9181 \\
\hline $3 / 6 / 2007$ & $12: 00$ & 18.88 & 16.25 & 0.2 & 1.949 & 82.62 & 91 & 18.27 & -1.29635 & 40.08075 \\
\hline $3 / 6 / 2007$ & $12: 30$ & 18.95 & 16.5 & 0.19 & 1.949 & 80.58 & 86.5 & 18.4 & -1.25903 & 38.1802 \\
\hline $3 / 6 / 2007$ & $13: 00$ & 19.15 & 16.56 & 0.2 & 1.999 & 79.9 & 87.1 & 18.42 & -1.24706 & 37.57817 \\
\hline $3 / 6 / 2007$ & $13: 30$ & 19.26 & 16.58 & 0.17 & 1.695 & 80.63 & 91.1 & 18.62 & -1.13574 & 32.16936 \\
\hline $3 / 6 / 2007$ & $14: 00$ & 19.34 & 16.93 & 0.22 & 2.231 & 81.01 & 90.1 & 18.65 & -1.2232 & 36.38866 \\
\hline $3 / 6 / 2007$ & $14: 30$ & 19 & 17.08 & 0.22 & 2.079 & 81.86 & 87.9 & 18.41 & -1.30528 & 40.54031 \\
\hline $3 / 6 / 2007$ & $15: 00$ & 18.78 & 16.91 & 0.19 & 1.757 & 82.22 & 88.1 & 18.16 & -1.30557 & 40.55505 \\
\hline $3 / 6 / 2007$ & $15: 30$ & 18.91 & 16.74 & 0.22 & 2.385 & 80.66 & 86.9 & 18.21 & -1.34847 & 42.78662 \\
\hline $3 / 6 / 2007$ & $16: 00$ & 19.21 & 16.77 & 0.27 & 2.015 & 80.47 & 86.4 & 18.74 & -1.32839 & 41.73762 \\
\hline $3 / 6 / 2007$ & $16: 30$ & 18.87 & 17.04 & 0.26 & 2.288 & 77.1 & 83.3 & 18.43 & -1.42484 & 46.84013 \\
\hline $3 / 6 / 2007$ & $17: 00$ & 18.71 & 16.2 & 0.16 & 2.192 & 74.43 & 76.2 & 18.09 & -1.29195 & 39.85529 \\
\hline $3 / 6 / 2007$ & $17: 30$ & 18.26 & 15.52 & 0.21 & 1.378 & 72.06 & 73 & 17.65 & -1.54503 & 53.35063 \\
\hline $3 / 6 / 2007$ & $18: 00$ & 17.77 & 14.88 & 0.28 & 0.964 & 71.33 & 75.1 & 17.24 & -1.81343 & 67.71211 \\
\hline
\end{tabular}


Ambiente: Ante-sala da Congregação

Período 4: 05 a 08 de julho de 2007

\begin{tabular}{|c|c|c|c|c|c|c|c|c|c|c|}
\hline Data & Hora & Temp. int. & Temp. ext. & Vel. Int. & Vel. Ext. & UR int. & UR ext. & $\begin{array}{l}\text { Temp, } \\
\text { Globo int. }\end{array}$ & PMV & PPD \\
\hline $5 / 7 / 2007$ & 8:00 & 20.24 & 15.39 & 0.14 & 0.222 & 58.32 & 75.7 & 19.54 & -0.92377 & 23.02223 \\
\hline $5 / 7 / 2007$ & 8:30 & 20.45 & 18.07 & 0.14 & 0.232 & 58.36 & 66.64 & 19.77 & -0.86544 & 20.80906 \\
\hline $5 / 7 / 2007$ & 9:00 & 21.09 & 20.32 & 0.16 & 0.506 & 57.97 & 59.61 & 20.43 & -0.74019 & 16.53479 \\
\hline $5 / 7 / 2007$ & 9:30 & 21.91 & 21.42 & 0.14 & 1.118 & 56.38 & 55.77 & 21.22 & -0.48825 & 9.980558 \\
\hline $5 / 7 / 2007$ & $10: 00$ & 22.83 & 22.31 & 0.19 & 1.408 & 53.99 & 52.58 & 22.13 & -0.34782 & 7.516993 \\
\hline $5 / 7 / 2007$ & $10: 30$ & 23.7 & 23.24 & 0.15 & 1.29 & 52.28 & 50.5 & 22.93 & -0.06077 & 5.076453 \\
\hline $5 / 7 / 2007$ & 11:00 & 24.61 & 23.43 & 0.16 & 1.53 & 50.15 & 49.92 & 23.78 & 0.149581 & 5.463621 \\
\hline $5 / 7 / 2007$ & $11: 30$ & 25.23 & 24.01 & 0.13 & 1.547 & 48.77 & 48.42 & 24.49 & 0.365186 & 7.77592 \\
\hline $5 / 7 / 2007$ & $12: 00$ & 25.92 & 24.38 & 0.15 & 1.758 & 46.83 & 47.23 & 25.25 & 0.516194 & 10.57186 \\
\hline $5 / 7 / 2007$ & $12: 30$ & 26.43 & 25 & 0.18 & 1.639 & 46.24 & 45.74 & 25.81 & 0.622082 & 13.11971 \\
\hline $5 / 7 / 2007$ & $13: 00$ & 26.93 & 25.68 & 0.14 & 1.432 & 45.16 & 44.7 & 26.36 & 0.803571 & 18.61489 \\
\hline $5 / 7 / 2007$ & $13: 30$ & 27.33 & 26.46 & 0.14 & 1.335 & 44.17 & 42.17 & 26.81 & 0.910448 & 22.50466 \\
\hline $5 / 7 / 2007$ & $14: 00$ & 27.65 & 27.19 & 0.11 & 1.053 & 42.1 & 38.5 & 27.13 & 1.01641 & 26.81568 \\
\hline $5 / 7 / 2007$ & $14: 30$ & 27.6 & 27.45 & 0.11 & 1.245 & 39.57 & 32.94 & 27.16 & 0.990946 & 25.74 \\
\hline $5 / 7 / 2007$ & $15: 00$ & 27.36 & 27.11 & 0.13 & 1.046 & 39.92 & 34.47 & 26.76 & 0.884161 & 21.50423 \\
\hline $5 / 7 / 2007$ & $15: 30$ & 27.53 & 27.72 & 0.13 & 0.885 & 40.48 & 33.89 & 27 & 0.94329 & 23.79374 \\
\hline $5 / 7 / 2007$ & $16: 00$ & 27.89 & 28.2 & 0.11 & 0.716 & 39.05 & 31.38 & 27.32 & 1.047212 & 28.14923 \\
\hline $5 / 7 / 2007$ & $16: 30$ & 27.65 & 27.3 & 0.11 & 1.087 & 39.56 & 33.69 & 27.09 & 0.989255 & 25.66941 \\
\hline $5 / 7 / 2007$ & $17: 00$ & 26.64 & 26.4 & 0.1 & 0.484 & 41.29 & 36.05 & 26.55 & 0.811502 & 18.88719 \\
\hline $5 / 7 / 2007$ & $17: 30$ & 25.96 & 27.13 & 0.1 & 0.197 & 42.52 & 35.32 & 25.28 & 0.570241 & 11.81157 \\
\hline $5 / 7 / 2007$ & $18: 00$ & 24.87 & 25.13 & 0.11 & 0.059 & 45.15 & 40.89 & 24.14 & 0.279777 & 6.625782 \\
\hline 6/7/2007 & 8:00 & 21.04 & 15.69 & 0.19 & 0.017 & 59.1 & 77.3 & 20.37 & -0.80899 & 18.8006 \\
\hline 6/7/2007 & $8: 30$ & 21.11 & 17.92 & 0.2 & 0.195 & 59.75 & 68.89 & 20.59 & -0.78808 & 18.09065 \\
\hline 6/7/2007 & 9:00 & 21.97 & 20.8 & 0.19 & 0.56 & 57.09 & 58.26 & 21.29 & -0.56462 & 11.67678 \\
\hline 6/7/2007 & 9:30 & 22.72 & 21.79 & 0.17 & 0.984 & 54.22 & 54.01 & 22.07 & -0.33718 & 7.364721 \\
\hline 6/7/2007 & $10: 00$ & 23.57 & 22.47 & 0.17 & 1.35 & 51.82 & 51.05 & 22.88 & -0.12411 & 5.319092 \\
\hline 6/7/2007 & $10: 30$ & 24.1 & 22.84 & 0.16 & 1.488 & 50.5 & 50.29 & 23.52 & 0.040751 & 5.034378 \\
\hline 6/7/2007 & 11:00 & 24.91 & 23.24 & 0.19 & 1.506 & 49.34 & 50.49 & 24.25 & 0.204123 & 5.864086 \\
\hline 6/7/2007 & $11: 30$ & 25.49 & 23.85 & 0.2 & 1.521 & 47.77 & 48.51 & 24.85 & 0.345211 & 7.479211 \\
\hline 6/7/2007 & $12: 00$ & 26.08 & 24.25 & 0.2 & 1.815 & 46.28 & 47.05 & 25.56 & 0.51328 & 10.50861 \\
\hline 6/7/2007 & $12: 30$ & 26.54 & 25.06 & 0.17 & 1.431 & 45.32 & 45.27 & 26.06 & 0.672358 & 14.49972 \\
\hline 6/7/2007 & $13: 00$ & 27.05 & 25.73 & 0.16 & 1.442 & 44.63 & 43.69 & 26.64 & 0.827475 & 19.44361 \\
\hline 6/7/2007 & $13: 30$ & 27.48 & 26.55 & 0.15 & 1.478 & 43.23 & 41.02 & 27.09 & 0.947633 & 23.96745 \\
\hline 6/7/2007 & $14: 00$ & 28 & 27.4 & 0.14 & 0.932 & 39.99 & 36.66 & 27.62 & 1.073626 & 29.32022 \\
\hline $6 / 7 / 2007$ & $14: 30$ & 28.32 & 27.92 & 0.16 & 0.768 & 38.18 & 32.66 & 27.96 & 1.128024 & 31.80821 \\
\hline 6/7/2007 & $15: 00$ & 28.09 & 27.56 & 0.12 & 0.565 & 38.05 & 33.48 & 27.81 & 1.115049 & 31.20568 \\
\hline 6/7/2007 & $15: 30$ & 27.61 & 27.26 & 0.14 & 0.738 & 38.94 & 33.75 & 27.12 & 0.945074 & 23.86502 \\
\hline 6/7/2007 & $16: 00$ & 26.77 & 26.73 & 0.11 & 0.505 & 40.38 & 35.39 & 26.13 & 0.753509 & 16.95776 \\
\hline $6 / 7 / 2007$ & $16: 30$ & 27.13 & 27.23 & 0.11 & 0.576 & 39.58 & 33.33 & 26.53 & 0.846803 & 20.13122 \\
\hline 6/7/2007 & $17: 00$ & 26.74 & 27.52 & 0.12 & 0.209 & 40.36 & 33.01 & 26.92 & 0.830378 & 19.54588 \\
\hline 6/7/2007 & $17: 30$ & 26.01 & 27.19 & 0.11 & 0.135 & 42.12 & 34.45 & 25.47 & 0.579454 & 12.03553 \\
\hline 6/7/2007 & $18: 00$ & 25.1 & 25.28 & 0.13 & 0.045 & 44.95 & 41.08 & 24.46 & 0.313282 & 7.040121 \\
\hline $7 / 7 / 2007$ & 8:00 & 21.8 & 18.12 & 0.25 & 0.201 & 56.31 & 67.28 & 21.15 & -0.70702 & 15.5149 \\
\hline $7 / 7 / 2007$ & $8: 30$ & 22.01 & 18.97 & 0.26 & 0.36 & 55.94 & 64.23 & 21.4 & -0.65867 & 14.11324 \\
\hline $7 / 7 / 2007$ & 9:00 & 22.43 & 19.87 & 0.15 & 0.658 & 54.9 & 61.56 & 21.86 & -0.36508 & 7.774297 \\
\hline $7 / 7 / 2007$ & 9:30 & 22.77 & 20.35 & 0.16 & 0.735 & 54.46 & 59.84 & 22.17 & -0.29825 & 6.848301 \\
\hline $7 / 7 / 2007$ & $10: 00$ & 23.22 & 20.86 & 0.22 & 0.879 & 53.63 & 58.17 & 22.64 & -0.27232 & 6.540031 \\
\hline $7 / 7 / 2007$ & $10: 30$ & 23.63 & 21.58 & 0.16 & 1.212 & 52.82 & 55.8 & 23.03 & -0.07406 & 5.11356 \\
\hline
\end{tabular}




\begin{tabular}{|c|c|c|c|c|c|c|c|c|c|c|}
\hline 7/7/2007 & $11: 00$ & 24.54 & 22.23 & 0.17 & 1.108 & 50.47 & 53.94 & 23.96 & 0.146254 & 5.443206 \\
\hline $7 / 7 / 2007$ & $11: 30$ & 25.69 & 23.23 & 0.14 & 1.715 & 47.37 & 50.16 & 25.02 & 0.471823 & 9.648553 \\
\hline 7/7/2007 & $12: 00$ & 26.47 & 24.11 & 0.19 & 1.618 & 45.71 & 48.05 & 25.89 & 0.62237 & 13.1273 \\
\hline $7 / 7 / 2007$ & $12: 30$ & 27.04 & 24.69 & 0.15 & 1.595 & 44.11 & 45.75 & 26.5 & 0.816419 & 19.05732 \\
\hline $7 / 7 / 2007$ & $13: 00$ & 27.57 & 25.2 & 0.15 & 1.775 & 43.22 & 44.63 & 27.03 & 0.954552 & 24.24568 \\
\hline $7 / 7 / 2007$ & $13: 30$ & 27.86 & 26.04 & 0.17 & 1.552 & 42.04 & 41.76 & 27.45 & 1.020049 & 26.97141 \\
\hline 7/7/2007 & $14: 00$ & 28.27 & 26.4 & 0.12 & 1.518 & 40.36 & 39.21 & 27.87 & 1.169426 & 33.76706 \\
\hline $7 / 7 / 2007$ & $14: 30$ & 28.11 & 26.25 & 0.1 & 0.959 & 39.97 & 38.9 & 27.64 & 1.139302 & 32.33639 \\
\hline $7 / 7 / 2007$ & $15: 00$ & 28.44 & 27.11 & 0.09 & 0.838 & 38.86 & 35.66 & 27.99 & 1.232332 & 36.84226 \\
\hline 7/7/2007 & $15: 30$ & 28.22 & 26.52 & 0.09 & 1.147 & 39.02 & 37.02 & 27.66 & 1.162249 & 33.42362 \\
\hline $7 / 7 / 2007$ & $16: 00$ & 27.78 & 26.47 & 0.12 & 1.077 & 40.07 & 37.42 & 27.17 & 1.009407 & 26.5174 \\
\hline $7 / 7 / 2007$ & $16: 30$ & 28 & 26.54 & 0.13 & 0.822 & 39.58 & 36.86 & 27.4 & 1.05384 & 28.44072 \\
\hline $7 / 7 / 2007$ & $17: 00$ & 27.51 & 26.46 & 0.12 & 0.95 & 40.19 & 36.31 & 27.8 & 1.048605 & 28.21034 \\
\hline 7/7/2007 & $17: 30$ & 26.73 & 25.72 & 0.09 & 0.799 & 41.71 & 38.98 & 26.1 & 0.788876 & 18.1174 \\
\hline $7 / 7 / 2007$ & $18: 00$ & 25.69 & 24.36 & 0.1 & 0.319 & 44.46 & 43.7 & 24.93 & 0.505105 & 10.33314 \\
\hline 8/7/2007 & $8: 00$ & 20.36 & 15.73 & 0.27 & 0.521 & 53.3 & 66.65 & 19.84 & -1.15043 & 32.86167 \\
\hline 8/7/2007 & 8:30 & 20.73 & 18.14 & 0.23 & 0.816 & 52.26 & 57.52 & 20.16 & -0.99524 & 25.91968 \\
\hline 8/7/2007 & 9:00 & 21.74 & 19.71 & 0.18 & 1.094 & 49.75 & 52.91 & 21.08 & -0.6528 & 13.94981 \\
\hline 8/7/2007 & $9: 30$ & 22.72 & 20.56 & 0.13 & 1.436 & 47.75 & 50.55 & 22.01 & -0.30804 & 6.972137 \\
\hline 8/7/2007 & $10: 00$ & 23.65 & 21.56 & 0.17 & 1.55 & 45.82 & 47.19 & 22.95 & -0.14462 & 5.433375 \\
\hline 8/7/2007 & $10: 30$ & 24.49 & 22.47 & 0.16 & 1.723 & 44.27 & 44.83 & 23.76 & 0.085392 & 5.150994 \\
\hline 8/7/2007 & $11: 00$ & 25.37 & 23.19 & 0.2 & 2.037 & 42.1 & 42.38 & 24.65 & 0.259191 & 6.394693 \\
\hline 8/7/2007 & $11: 30$ & 26.08 & 23.93 & 0.19 & 2.039 & 40.62 & 40.42 & 25.38 & 0.458777 & 9.393258 \\
\hline 8/7/2007 & $12: 00$ & 26.67 & 24.84 & 0.2 & 1.707 & 39.35 & 38.28 & 26.1 & 0.6173 & 12.99415 \\
\hline 8/7/2007 & $12: 30$ & 27.15 & 25.22 & 0.23 & 1.506 & 39.18 & 38.32 & 26.6 & 0.726902 & 16.12058 \\
\hline 8/7/2007 & $13: 00$ & 27.64 & 26.42 & 0.19 & 1.646 & 37.25 & 33.96 & 27.11 & 0.884373 & 21.51217 \\
\hline 8/7/2007 & $13: 30$ & 27.94 & 26.9 & 0.13 & 1.354 & 36.41 & 32.65 & 27.48 & 1.026444 & 27.24627 \\
\hline 8/7/2007 & $14: 00$ & 28.32 & 27.53 & 0.13 & 1.146 & 36.1 & 31.99 & 27.83 & 1.122196 & 31.53687 \\
\hline 8/7/2007 & $14: 30$ & 28.4 & 27.74 & 0.1 & 1.207 & 35.53 & 31 & 27.94 & 1.176678 & 34.11569 \\
\hline 8/7/2007 & $15: 00$ & 28.61 & 28.08 & 0.1 & 1.229 & 34.28 & 28.74 & 28.1 & 1.213912 & 35.93008 \\
\hline 8/7/2007 & $15: 30$ & 28.71 & 28.78 & 0.11 & 0.602 & 34.05 & 27.56 & 28.21 & 1.227787 & 36.61633 \\
\hline 8/7/2007 & $16: 00$ & 28.4 & 28.69 & 0.11 & 0.523 & 34.44 & 28.3 & 28.12 & 1.176939 & 34.12825 \\
\hline 8/7/2007 & $16: 30$ & 28.23 & 28.84 & 0.11 & 0.458 & 35.18 & 27.61 & 27.66 & 1.102589 & 30.63238 \\
\hline 8/7/2007 & $17: 00$ & 27.82 & 28.49 & 0.15 & 0.245 & 36.09 & 28.2 & 28.11 & 1.059377 & 28.68543 \\
\hline 8/7/2007 & $17: 30$ & 27.1 & 27.85 & 0.12 & 0.114 & 37.64 & 30.64 & 26.39 & 0.794862 & 18.31895 \\
\hline 8/7/2007 & $18: 00$ & 25.98 & 25.78 & 0.11 & 0.082 & 39.85 & 35.27 & 25.24 & 0.529149 & 10.85748 \\
\hline
\end{tabular}

